\title{
Technical Support Document: 50\% Energy Savings Design Technology Packages for Medium Office Buildings
}

\author{
BA Thornton \\ W Wang \\ MD Lane \\ MI Rosenberg \\ B Liu, Project Manager
}

September 2009

\section{Pacific Northwest}

NATIONAL LABORATORY

Proudly Operated by Battelle Since 1965 


\title{
DISCLAIMER
}

This report was prepared as an account of work sponsored by an agency of the United States Government. Neither the United States Government nor any agency thereof, nor Battelle Memorial Institute, nor any of their employees, makes any warranty, express or implied, or assumes any legal liability or responsibility for the accuracy, completeness, or usefulness of any information, apparatus, product, or process diselosed, or represents that its use would not infringe privately owned rights. Reference herein to any specific commercial product, process, or service by trade name, trademark, manufacturer, or otherwise does not necessarily constitute or imply its endorsement, recommendation, or favoring by the United States Government or any agency thereof, or Battelle Memorial Institute. The views and opinions of authors expressed herein do not necessarily state or reflect those of the United States Government or any agency thereof.

\author{
PACIFIC NORTHWEST NATIONAL LABORATORY \\ operated by \\ BATTELLE \\ for the \\ UNITED STATES DEPARTMENT OF ENERGY \\ under Contract DE-AC05-76RL01830
}

Printed in the United States of America

Available to DOE and DOE contractors from the

Office of Scientific and Technical Information,

P.O. Box 62, Oak Ridge, TN 37831-0062;

ph: (865) 576-8401

fax: (865) 576-5728

email: reports@adonis.osti.gov

\author{
Available to the public from the National Technical Information Service, \\ U.S. Department of Commerce, 5285 Port Royal Rd., Springfield, VA 22161 \\ ph: (800) 553-6847 \\ fax: (703) 605-6900 \\ email: orders@ntis.fedworld.gov \\ online ordering: http://www.ntis.gov/ordering.htm
}

This document was printed on recycled paper. 


\title{
Technical Support Document: 50\% Energy Savings Design Technology Packages for Medium Office Buildings
}

\author{
BA Thornton \\ W Wang \\ MD Lane* \\ MI Rosenberg \\ B Liu, Project Manager
}

September 2009

Prepared for

the U.S. Department of Energy

under Contract DE-AC05-76RL01830

Pacific Northwest National Laboratory

Richland, Washington 99352

*Mr. Michael Lane works for Seattle Lighting Design Lab in Seattle, WA. 



\section{Executive Summary}

The Technical Support Document (TSD) for 50\% energy savings in medium office buildings documents the analysis and results for a recommended package of energy saving design features. Implementation of these energy measures could allow a new medium office building to achieve 50\% energy savings relative to a building that just meets ANSI/ASHRAE/IESNA Standard 90.1-2004, Energy Standard for Buildings Except Low-Rise Residential Buildings. This package includes radiant heating and cooling with dedicated outdoor air systems (DOAS). Documentation and results are also presented for a second energy measure package that relies on a more conventional high performance variable air volume (VAV) system but does not achieve 50\% energy savings in all 16 climate locations analyzed for this project.

The Department of Energy (DOE) through its Building Technologies Program commissioned this work to support its goal to create technologies and design approaches that enable net-zero energy buildings at low incremental cost by 2025. This work is related to previous technical support documents that were used in the development of Advanced Energy Design Guides published by ASHRAE (such as the Advanced Energy Design Guide for Highway Lodging). However, unlike those previous TSD reports, this effort results in a stand-alone report that is not part of a formal project under ASHRAE's Special Project procedures to develop an Advanced Energy Design Guide for Medium Offices. This study may be used to support development of such a design guide, but may also be used separately to demonstrate the feasibility of achieving 50\% energy reduction for medium office buildings across the full range of climate zones in the United States.

This report and others under the 50\% TSD project by DOE may also support DOE's Commercial Building National Accounts Program. This program provides technical support to large corporate building owners and managers seeking to achieve 50\% energy savings in new commercial buildings, and $30 \%$ savings in existing commercial buildings.

Pacific Northwest National Laboratory (PNNL) performed the research, analysis and documentation for this report with input from many other contributors and sources of information. PNNL developed a prototype building model that just meets the requirements of Standard 90.1-2004 based on the DOE medium office benchmark building. Prescriptive packages of recommended energy measures were developed. PNNL used energy simulation with EnergyPlus version 3.0 to determine the energy savings provide by the package of measures. The prototype buildings were simulated in the same 8 climate zones, utilizing 16 city locations used by the prevailing energy codes and standards to evaluate energy savings.

The report documents the modeling assumptions used in the simulations for both the baseline and advanced prototypical buildings. Final efficiency recommendations for each climate zone are included, along with the results of the energy simulations. A primary package of energy measures, which includes radiant heating and cooling with DOAS, provides a national-weighted average energy savings of $56.1 \%$ over the Standard 90.1-2004 for 16 climate settings (savings for the different climate zones are weighted by construction square footage per location). A second package of measures is also analyzed and differs from the first package only in the heating, ventilating, and air-conditioning (HVAC) systems, which are VAV systems, and demonstrates weighted average savings potential of $46.3 \%$ overall. 
A cost estimate of each package of energy measures is provided to evaluate cost-effectiveness relative to the energy savings. The primary package with radiant systems has an average payback of 7.6 years, and the package with VAV systems has an average payback of 4.6 years. Lighting costs are lower for the recommended energy measures than for the baseline because reduced wattage and fixture costs are only partially offset by more expensive per watt lighting equipment. This reduction may not be achievable for projects with very high lighting aesthetic considerations. HVAC system costs take into account greatly reduced system cooling capacity. Some design teams may not be willing to take into account large reductions in equipment sizing relative to typical design. Actual cost premiums may vary but the costeffectiveness analysis does suggest that 50\% energy savings can be achieved for new medium offices with a reasonable cost premium. 


\section{Acknowledgments}

This document was prepared by Pacific Northwest National Laboratory (PNNL) for the U.S. Department of Energy's Building Technologies (BT) Program. The authors would like to thank Dr. Dru Crawley, Team Leader of BTP’s Commercial Buildings Integration R\&D, for his dedicated support to and thoughtful guidance of this project.

The authors would like to thank all the external peer reviewers for their tremendous volunteer efforts and insightful reviews of our energy analysis work during the development of this report. Without their expertise in reviewing the energy efficiency measures covering envelope, lighting, HVAC systems, and service water heating systems, this document would be considerably less rigorous. The following experts peer reviewed an earlier draft of this report:

Erin McConahey, Principal, ARUP

Floyd Barwig, Director, Office of Energy Efficiency and Environment, New York State Public Service Commission

Glenn Hansen, Project Manager, Portland Energy Conservation Incorporated

Kent Peterson, President, P2S Engineering

Dr. Merle McBride, Owens Corning Science and Technology Center

Michael Lane, Project Manager, Seattle Lighting Design Lab

Oliver Baumann, President, Ebert \& Bauman Consulting Engineers, Inc.

Last, but not least, the authors would like to specially recognize Andrew Nicholls, the program manager overseeing the Commercial Building Integration Program at PNNL, for his strong support of this particular project. The authors greatly appreciate the assistance of Todd Taylor at PNNL. Todd constructed the cluster simulation structure in EnergyPlus, which allowed us to evaluate the many variations of energy efficiency technologies in a timely fashion to meet the project's compressed schedule. Finally, Dr. Jian Zhang at PNNL provided a detailed technical review of this report.

This project was a true team effort and the authors would like to express their deep appreciation to everyone who contributed to the completion of this work.

Bing Liu

Project Manager

Pacific Northwest National Laboratory 


\title{
Acronyms and Abbreviations
}

\author{
AC air conditioner \\ AEDG-SO Advanced Energy Design Guide for Small Office Buildings \\ AEDG-SR Advanced Energy Design Guide for Small Retail Buildings \\ AFUE annual fuel utilization efficiency \\ AHU air handling unit \\ AIA American Institute of Architects \\ ANSI American National Standards Institute \\ ASHRAE American Society of Heating, Refrigerating and Air-Conditioning Engineers \\ BT Building Technologies \\ CBECS Commercial Buildings Energy Consumption Survey \\ CDD cooling degree days \\ CFL compact fluorescent lamp \\ COP coefficient of performance \\ CPU central processing unit \\ DCV demand controlled ventilation \\ DOAS dedicated outdoor air system \\ DOE Department of Energy \\ DX direct expansion \\ EEM energy efficiency measures \\ EER energy efficiency ratio \\ EIA Energy Information Administration \\ EPA Environmental Protection Agency \\ EPDM ethylene propylene diene terpolymer membrane \\ ERV energy recovery ventilation
}




\begin{tabular}{|c|c|}
\hline GSHP & ground source heat pump \\
\hline HDD & heating degree days \\
\hline HP & high performance \\
\hline HVAC & heating, ventilation, and air conditioning \\
\hline IECC & International Energy Conservation Code \\
\hline IESNA & Illuminating Engineering Society of North America \\
\hline IPLV & integrated part load value \\
\hline LEED & Leadership in Energy and Environmental Design \\
\hline LBNL & Lawrence Berkeley National Laboratory \\
\hline LCD & Liquid Crystal Display \\
\hline LPD & lighting power density \\
\hline NBI & New Buildings Institute \\
\hline NEA & National Energy Alliances \\
\hline NREL & National Renewable Energy Laboratory \\
\hline NZEB & net-zero energy buildings \\
\hline ODP & open drip proof \\
\hline OSA & outdoor supply air \\
\hline PLR & part load ratio \\
\hline PNNL & Pacific Northwest National Laboratory \\
\hline RA & return air \\
\hline RTU & roof top unit \\
\hline SEER & seasonal energy efficiency ratio \\
\hline SHGC & solar heat gain coefficient \\
\hline SWH & service water heating \\
\hline TEFC & totally enclosed fan cooled \\
\hline
\end{tabular}




$\begin{array}{ll}\text { TSD } & \text { technical support document } \\ \text { USGBC } & \text { US Green Building Council } \\ \text { USGS } & \text { US Geological Survey } \\ \text { VAV } & \text { variable air volume } \\ \text { VLT } & \text { visible light transmittance } \\ \text { WWR } & \text { window-to-wall ratio }\end{array}$




\section{Contents}

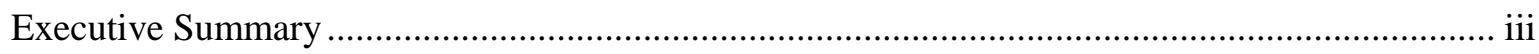

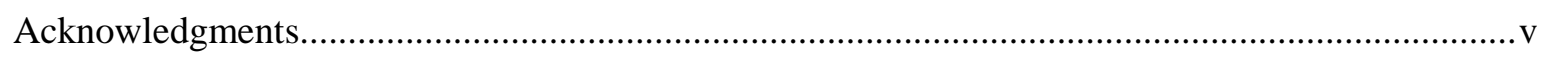

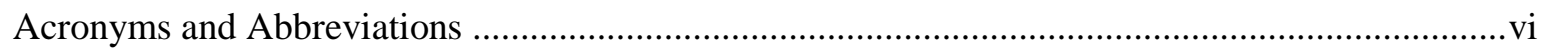

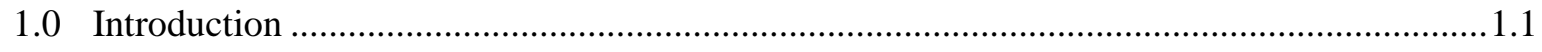

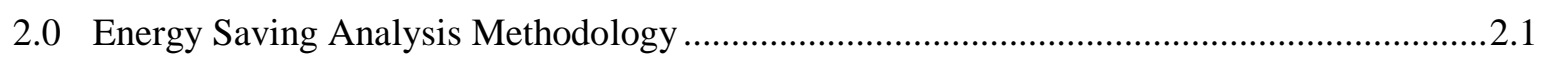

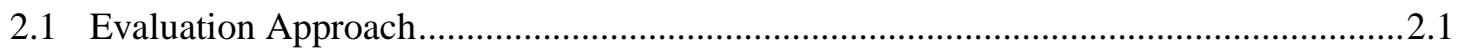

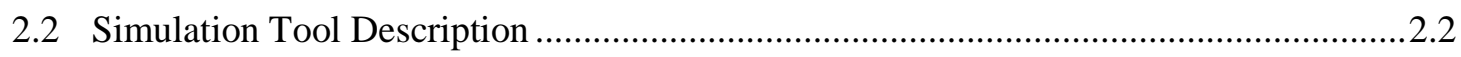

2.3 Climate Zones and Weighting Factors ...................................................................2.2

2.4 Development of the Medium Office Prototype Building ..............................................2.5

3.0 Development of Baseline Building Model and Assumptions................................................

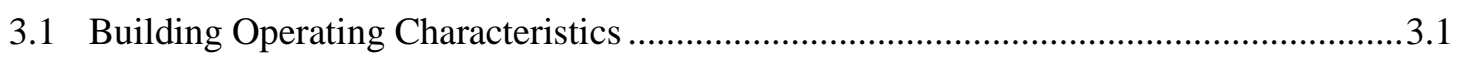

3.2 Baseline Building Envelope Characteristics .............................................................

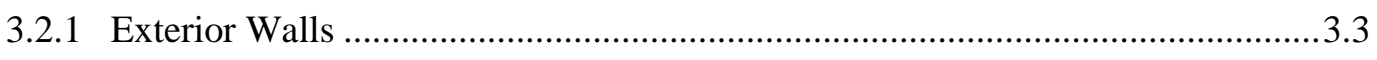

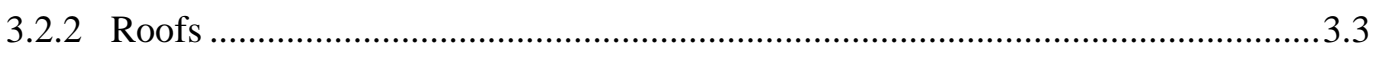

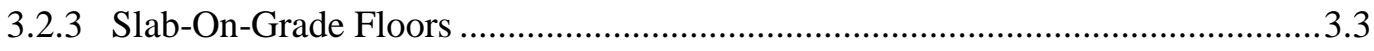

3.2.4 Fenestration .............................................................................................

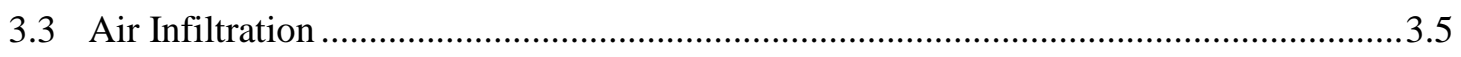

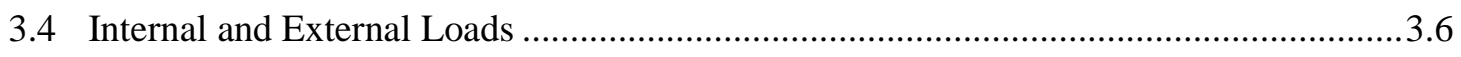

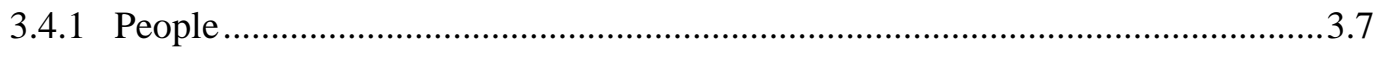

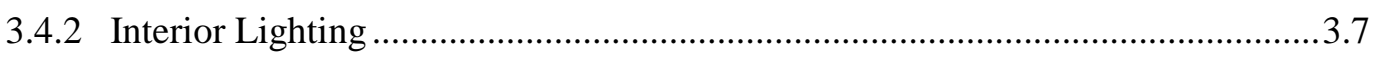

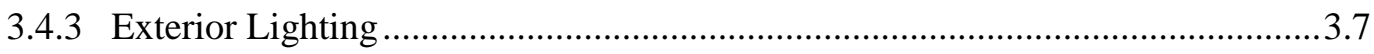

3.4.4 Miscellaneous Equipment (Plug Loads)............................................................. 3.9

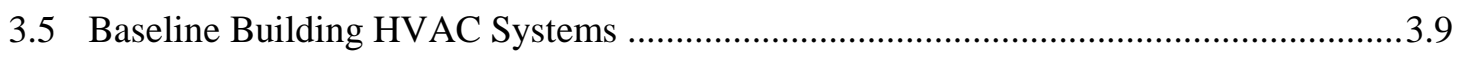

3.5.1 Building HVAC Operating Schedules ................................................................. 3.9

3.5.2 HVAC Zoning ............................................................................................... 3.11

3.5.3 Heating and Cooling Thermostat Setpoint ..................................................... 3.11

3.5.4 HVAC Equipment Sizing.............................................................................. 3.11

3.5.5 HVAC Equipment Efficiency …………...........................................................12

3.5.6 HVAC System Fan Power.............................................................................. 3.13

3.5.7 Outdoor Air Ventilation Rates and Schedules ...................................................14

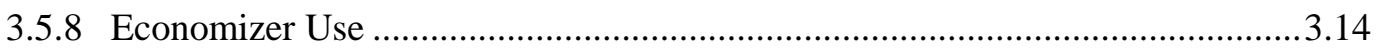

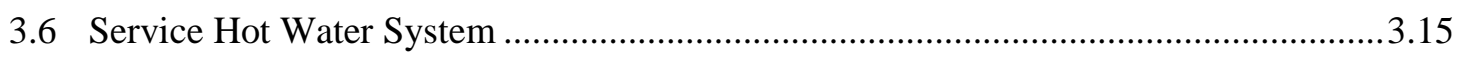

3.6.1 Hot Water Usage ..........................................................................................

3.6.2 Storage Tank Size.............................................................................................16

3.6.3 Rated Input Power and Standby Heat Loss Coefficient ......................................16

3.6.4 Water Heater Thermal Efficiency ….................................................................17 
4.0 Development of Advanced Building Model and Assumptions ..........................................4.1

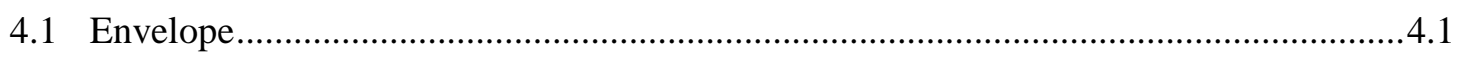

4.1.1 Enhanced Insulation for Opaque Assemblies..........................................................4.1

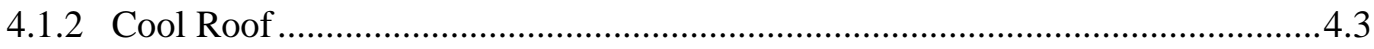

4.1.3 High Performance Windows ...................................................................... 4.3

4.1.4 Permanent Shading Devices ..............................................................................4.5

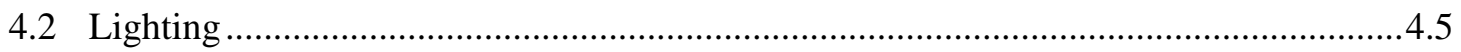

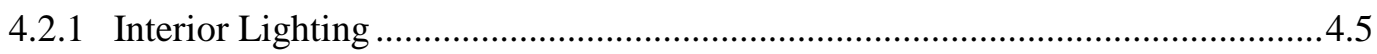

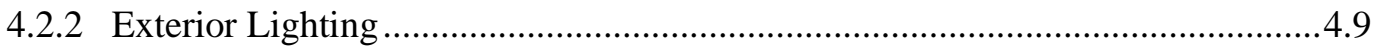

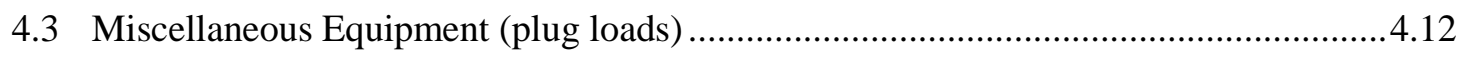

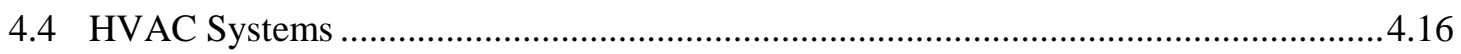

4.4.1 Dedicated Outdoor Air System ........................................................................ 4.16

4.4.2 Radiant Heating and Cooling System .............................................................4.19

4.4.3 Premium HVAC Equipment Efficiency........................................................2.

4.4.4 Motorized Outdoor Air Damper Control.............................................................2.22

4.4.5 Demand-Controlled Ventilation ....................................................................23

4.5 Alternative HVAC Systems - Variable Air Volume ......................................................4.23

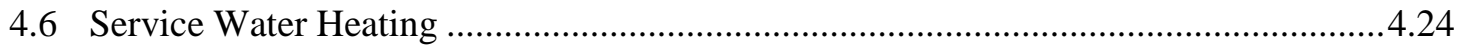

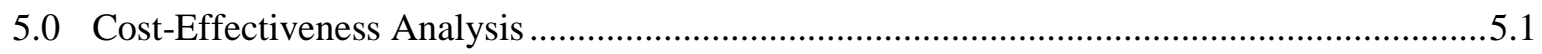

5.1 Basis for Incremental Energy Savings Measure Costs ................................................. 5.1

5.2 Comparison of Incremental Costs to Baseline Costs for Construction ............................5.3

5.3 Cost-Effectiveness Calculations.................................................................................. 5.8

5.4 A Perspective on Costs for Advanced Buildings ........................................................... 5.9

6.0 Recommendations and Energy Savings Results............................................................. 6.1

6.1.1 Envelope Measures ..................................................................................... 6.1

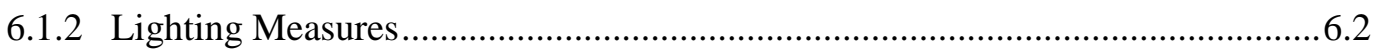

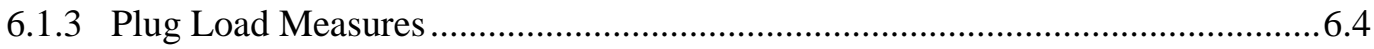

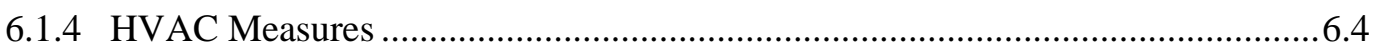

6.1.5 Service Water Heating Measures ..................................................................6.6

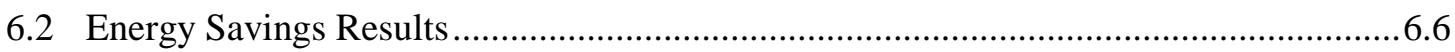

6.2.1 Results with Radiant Systems and Dedicated Outdoor Air..................................6.6

6.2.2 Results with Variable Air Volume Systems .....................................................6.11

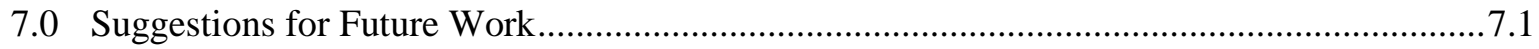

7.1 Purpose and Goals ................................................................................................ 7.1

7.2 Adjustments to Prototypes and Baseline Model............................................................. 7.1

7.3 Advanced Building - Additional Potential Energy Measures..........................................7.2

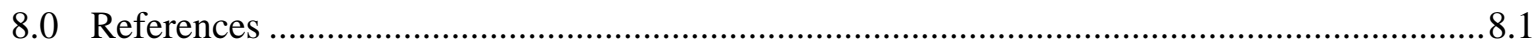

Appendix A Energy Modeling Input Assumptions.................................................................... A.1

Appendix B Review Comments and Responses ........................................................................... B.1 


\section{Figures}

Figure 2.1. DOE-Developed Climate Zone Map ........................................................................ 2.3

Figure 3.1. Medium Office Weekday Schedules ..........................................................................

Figure 3.2. Axonometric View of Medium Office Building …....................................................

Figure 3.3. HVAC Zoning Map for the Medium Office Building...............................................3.11

Figure 4.1. The Change of Interior Lighting Schedules from Occupancy Sensors........................4.7

Figure 4.2. DOAS With Dual Wheels and Deep Cooling Coil................................................17

Figure 4.3. DOAS With Enthalpy Wheel, Conventional Cooling Coil and Heating Coil ............4.17

Figure 4.4. Slab-on-Grade Floor Construction .....................................................................4.20

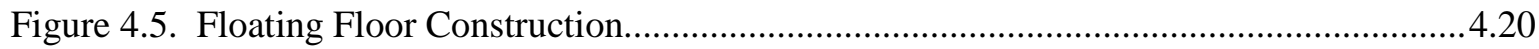

Figure 4.6. Weekday Schedule of the Mean Air Temperature Setpoint ......................................4.21

Figure 6.1. Percentage Energy Savings by Climate Zone (Radiant System) ...............................6.7

Figure 6.2. Comparison of Energy End Use Intensities Between the Baseline and Advanced Models (Radiant System)...

Figure 6.3. Percentage Energy Savings by Climate Zone (VAV System).................................6.12

Figure 6.4. Comparison of Energy End Use Intensities Between the Baseline and Advanced

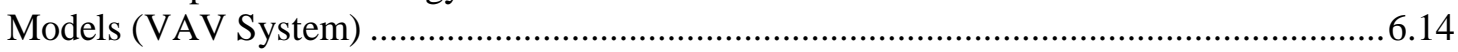

\section{Tables}

Table 2.1. Construction Volume Weights for All ASHRAE Building Prototypes and Climate

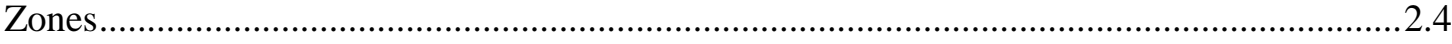

Table 2.2. Construction Weights for Medium Office ..............................................................2.4

Table 3.1. Fenestration U-Factor and SHGC Values for the Baseline Models................................5

Table 3.2. Exterior Lighting Power Allowances............................................................................

Table 3.3. Plug Load Density Calculations for the Baseline Prototype........................................10

Table 3.4. Single Packaged Air Conditioner Baseline Efficiency ................................................13

Table 3.5. Economizer Requirements in the Standard 90.1-2004...............................................15

Table 4.1. Insulation Requirements for Above Grade Steel-Framed Walls...................................4.2

Table 4.2. Insulation Requirements for the Roof with Continuous Insulation Above Deck ..........4.3

Table 4.3. Fenestration U-factor and SHGC values....................................................................4.4

Table 4.4. Lighting Power Density Calculation for the Advanced Case ......................................4.6

Table 4.5. Lighting Energy Saving from the Increased Use of Occupancy Sensors ......................4.8

Table 4.6. Exterior Lighting Power Allowances.........................................................................4.11

Table 4.7. Plug Load Calculation for the Advanced Case without Additional Controls ..............4.13

Table 4.8. Estimated Additional Reduction in Plug Loads Energy Usage with Controls.............4.15

Table 4.9. Changes in Plug Equipment Schedules with Added Controls ...................................4.15 
Table 4.10. Rated Performance of the Energy Recovery Ventilators .....

Table 4.11. Higher Efficiency for Packaged Unitary Air Conditioners for the Advanced Case ..4.22

Table 4.12. Improved Motor Efficiency ..... 4.22

Table 5.1. Cost Calculation Method Summary - Radiant System................................................5.2

Table 5.2. Cost Calculation Method Summary - VAV System ..................................................5.3

Table 5.3. Incremental Cost - Radiant System.........................................................................5.4

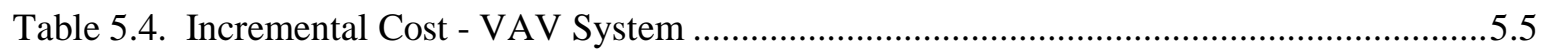

Table 5.5. Unit Cost Increase - Radiant System.........................................................................5.6

Table 5.6. Unit Cost Increase - VAV System ............................................................................5.7

Table 5.7. Simple Payback Period - Radiant System ................................................................ 5.8

Table 5.8. Simple Payback Period - VAV System ...................................................................5.9

Table 6.1. Final Energy Savings Recommendations for Medium Office - Building Envelope .....6.2

Table 6.2 Final Energy Savings Recommendations - Lighting.................................................6.3

Table 6.3 Final Energy Savings Recommendations - Plug Loads ............................................6.4

Table 6.4 Final Energy Savings Recommendations - HVAC .....................................................6.5

Table 6.5 Weighted Average Energy Savings for Recommended Energy Measures (Radiant

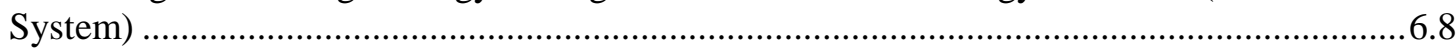

Table 6.6 Energy Savings Results by End Use (Radiant System) ............................................. 6.10

Table 6.7 Weighted Average Energy Savings for Recommended Energy Measures (VAV System)6.13

Table 6.8 Energy Savings Results by End Use (VAV System). 6.15 


\subsection{Introduction}

Buildings account for over $40 \%$ of total energy use and over $70 \%$ of electricity use in the United States. To tackle this challenge, the Department of Energy (DOE) has, through its Building Technologies Program, established a strategic goal to "create technologies and design approaches that enable netzero energy buildings (NZEB) at low incremental cost by 2025 ".

To reach NZEB by 2025, DOE BT has implemented a strategy to develop information packages and tools to support realization of 30\%, 50\% and 70\% better buildings, relative to ANSI/ASHRAE/ IESNA Standard 90.1-2004 (ANSI/ASHRAE/IESNA 2004). Beginning in FY2004, DOE has provided financial and technical support for the development the Advanced Energy Design Guides and Technical Support Documents in conjunction with these partnering organizations: the American Society of Heating, Refrigerating and Air Conditioning Engineers (ASHRAE), the American Institute of Architects (AIA), the Illuminating Engineering Society of North America (IES), and the U.S. Green Building Council (USGBC) ${ }^{1}$.

There are two distinct but related products under this element. An Advanced Energy Design Guide (AEDG) is a publication targeted at architects and other practitioners that provides specific guidance on how to achieve certain levels of high energy performance in buildings. A Technical Support Document (TSD) is a background document describing the assumptions and methodologies used to achieve particular levels of energy performance. AEDGs invariably have concomitant TSDs (to document the rationale behind the design decisions), but not all TSDs are necessarily associated with AEDGs.

ASHRAE and its partners have, to date, published five design guides focused on new construction in small commercial buildings. Building types covered include small office, small retail, K-12 school, small warehouse and self-storage, and highway lodging ${ }^{2}$. The purpose of these Guides is to provide recommendations for achieving at least 30\% energy savings over the minimum code requirements of ASHRAE Standard 90.1-1999 (ANSI/ASHRAE/IESNA 1999). The sixth and final Guide in this 30\% series for small healthcare facilities will be published in FY2010.

The 30\% energy savings target is the first step toward achieving net-zero commercial buildings. Having proven the feasibility of $30 \%$ energy savings across a variety of building types, DOE now exits the $30 \%$ design guide area and focuses on the informational products to realize $50 \%$ and $70 \%$ wholebuilding energy savings levels across a variety of climate zones, building types, energy intensities and sizes. The purpose of this Technical Support Document, or TSD, is to provide design technology packages that indicate, measure by measure, how to achieve $50 \%$ energy savings relative to Standard 90.1-2004 for medium-sized office buildings.

Prior to this TSD, the initial 30\% series Guides were developed by a project committee administered under ASHRAE's Special Project procedures. The AEDG project committee included membership from each of the partner organizations. Two of DOE's national laboratories, Pacific Northwest National

\footnotetext{
${ }^{1}$ The published AEDG guides are available for free download at http://www.ashrae.org/technology/page/938

${ }^{2}$ In addition, the New Buildings Institute participated in the development of the AEDG for Small Office Buildings.
} 
Laboratory (PNNL) and National Renewable Energy Laboratory (NREL), have provided leadership and energy analysis support to the various AEDG project committees in the past. Proceeding to the 50\% guides, DOE decided to develop the TSDs first to greatly expedite the speed at which the final guides are provided by ASHRAE to the market to impact actual design decisions in new commercial buildings. These 50\% TSDs do not necessarily support ASHRAE-published AEDGs, but are intended to be standalone reports documenting the technical feasibility of achieving a 50\% reduction in whole-building energy use. These reports are intended to demonstrate that exemplary energy performance is feasible today with available technology.

In FY2009, PNNL focused on two building types to analyze 50\% energy savings performance: medium offices (this report) and highway lodging (published as a sister report) for three reasons. First, these subsectors use a significant amount of energy and therefore represent significant opportunities for significant energy savings potential. Second, DOE has launched three commercial building energy alliances (CBAs) that include both lodging and offices. Because the goal of the CBEAs is ultimately to realize 50\% energy savings in new construction, the TSDs will directly support this effort to realize energy efficiency at scale through national account replication. Finally, PNNL possesses technical expertise in both areas, as evidenced by the previous development of the $30 \%$ AEDG for Small Offices and Highway Lodging.

Publication and use of these two design technology packages for office and lodging will lead to additional energy efficient design improvements well beyond code in our nation's new office and motels and will thus significantly contribute to BT's net-zero energy building goal in 2025. For reference, office and lodging are ranked as the first and fourth largest in terms of primary energy consumption in the commercial building sector, respectively, if all size categories are included. The combination of the office and lodging sectors constitutes $26 \%$ of the primary energy consumption in existing commercial buildings and represents $24 \%$ of the total square footage in the commercial building stock. ${ }^{3}$ The design technology packages will provide a sensible, hands-on approach to design through the use of "off-the-shelf" technologies and products that are practical and commercially available from major manufacturers.

\footnotetext{
${ }^{3} 2008$ Buildings Energy Data Book, U.S. Department of Energy, Table 3.2.2 http://buildingsdatabook.eren.doe.gov/docs/xls_pdf/3.2.2.pdf
} 


\subsection{Energy Saving Analysis Methodology}

This section describes the energy savings evaluation approach, the simulation program, and the climate locations that were used to assess and quantify the 50\% energy savings goal by implementing the energy efficiency measures recommended by this report.

\subsection{Evaluation Approach}

The evaluation approach was similar to the one used for the development of the initial $30 \%$ Advanced Energy Design Guide series, where prototypical buildings were devised, and then simulated in eight climate zones covered in ASHRAE Standard 90.1 (ANSI/ASHRAE/IESNA 2004). The 30\% AEDG series used 15 cities to represent the climate zones (Jarnagin et al. 2006; Liu et al. 2006; Liu et al. 2007; Pless et al. 2007; Jiang et al. 2008). This report uses 16 cities selected by the Department of Energy in establishing a new set of benchmark buildings. The DOE benchmark buildings are described in the next section, 3.0 Development of the Medium Office Prototype Building. The medium office prototype model used for this analysis is based closely on the DOE medium office benchmark building. The analysis results established that the energy efficiency recommendations in the TSD study meet the energy savings target.

The 50\% energy savings goal is based on onsite energy savings between minimally code compliant (baseline) medium office buildings and advanced ones that use the recommendations in the TSD study. The baseline level energy use was modeled to match buildings built beginning in 2004 and compliant with ASHRAE Standard 90.1-2004. The purpose of this building energy simulation analysis is to assess and quantify the energy savings potential of the Report's final recommendations. A series of steps is taken to reach this goal.

- Develop a prototypical medium office building description. The DOE medium office benchmark building is chosen as a starting point to develop the prototype. Section 2.4 in this report describes the development of the prototypical building.

- Create a baseline model from the prototype that is minimally code compliant for ASHRAE Standard 90.1-2004. Section 3.0 documents the model inputs and assumptions for the baseline models.

- Create an advanced model based on the recommended energy-efficient technologies in the Report. At the beginning of the technology selection, technologies are selected from the lists generated for the previous AEDGs (i.e., the most stringent requirements for envelope and lighting from Advanced Energy Design Guide for Small Office Buildings [AEDG-SO] and Advanced Energy Design Guide for Small Retail Buildings [AEDG-SR. To reach the 50\% goal, technologies are also identified nearer to current best practice and in some cases less prevalently used technologies, although commercially available and perhaps used more extensively outside the United States in some cases. This effort is also informed by the work of the ASHRAE Standing Standard Project Committee (SSPC) 90.1 engaged in developing the next generation of the Standard. Various technologies are considered in combination to determine the ability of the combination of measures to allow the energy savings target to be reached. Section 4.0 documents the model inputs and assumptions for the advanced models.

- The cost-effectiveness of the energy efficiency recommendations is presented in Section 5.0. 
- Evaluate 50\% energy savings in all 16 representative climate cities. A total of 16 climate locations are selected to adequately represent the 8 climate zones in the United States consistent with the DOE benchmark buildings. The summary of energy simulation results for all locations and the final energy saving recommendations by climate zone are described in Section 6.0.

\subsection{Simulation Tool Description}

EnergyPlus Version 3.0 (released in November, 2008) is used to assess the energy savings potential of the energy efficiency measures recommended in the TSD report. EnergyPlus is a complex building energy simulation program for modeling building heating, cooling, lighting, ventilating, and other energy flows under development by DOE since 1996 (DOE 2008). While it is based on the most popular features and capabilities of BLAST and DOE-2, EnergyPlus includes many innovative simulation capabilities, such as time steps of less than 1 hour, modular systems and plants integrated with heat balance-based zone simulation, multi-zone air flow, thermal comfort, and renewable energy systems. EnergyPlus is a heavily tested program with formal validation efforts repeated for every release ${ }^{1}$.

All energy simulations are completed with PNNL Linux energy simulation infrastructure, which manages inputs and outputs of the EnergyPlus simulations. This infrastructure includes creating EnergyPlus input files by a PNNL-developed program known as GPRM, submitting input files to a 50central processing unit (CPU) computing cluster for batch simulation, and extracting energy end use results.

\subsection{Climate Zones and Weighting Factors}

Prior to this report, the released AEDGs developed to date have standardized climate zones that have been adopted by IECC as well as ASHRAE for both residential and commercial applications. This results in a common set of climate zones for use in codes and standards. The common set of climate zones includes eight zones covering the entire United States, as shown in Figure 2.1 (Briggs et al. 2003). Climate zones are categorized from 1 to 8, with increasing heating degree days (HDDs) and decreasing cooling degree days (CDDs). These climate zones may be mapped to other climate locations for international use. The climate zones are further divided into moist and dry regions. A specific climate location (city) is selected as a representative of each climate zone. The AEDG 30\% series selected 15 cities as the representative climate locations.

For this project we selected a revised set of 16 cities that balance the representativeness of the climate zones and the number of buildings in the climate zones as shown below. Two locations were selected for climate zone 3B because we felt that these are two important locations with very different climates, which is evident from the results of the energy simulations of the benchmark building models. We have designated the two 3B climate zones as "3B-CA" for the California coast in climate zone 3B and "3Bother”.

\footnotetext{
${ }^{1}$ For the details of the test and validations of EnergyPlus program, go to http://apps1.eere.energy.gov/buildings/EnergyPlus/testing.cfm. Last accessed on September 26, 2008.
} 


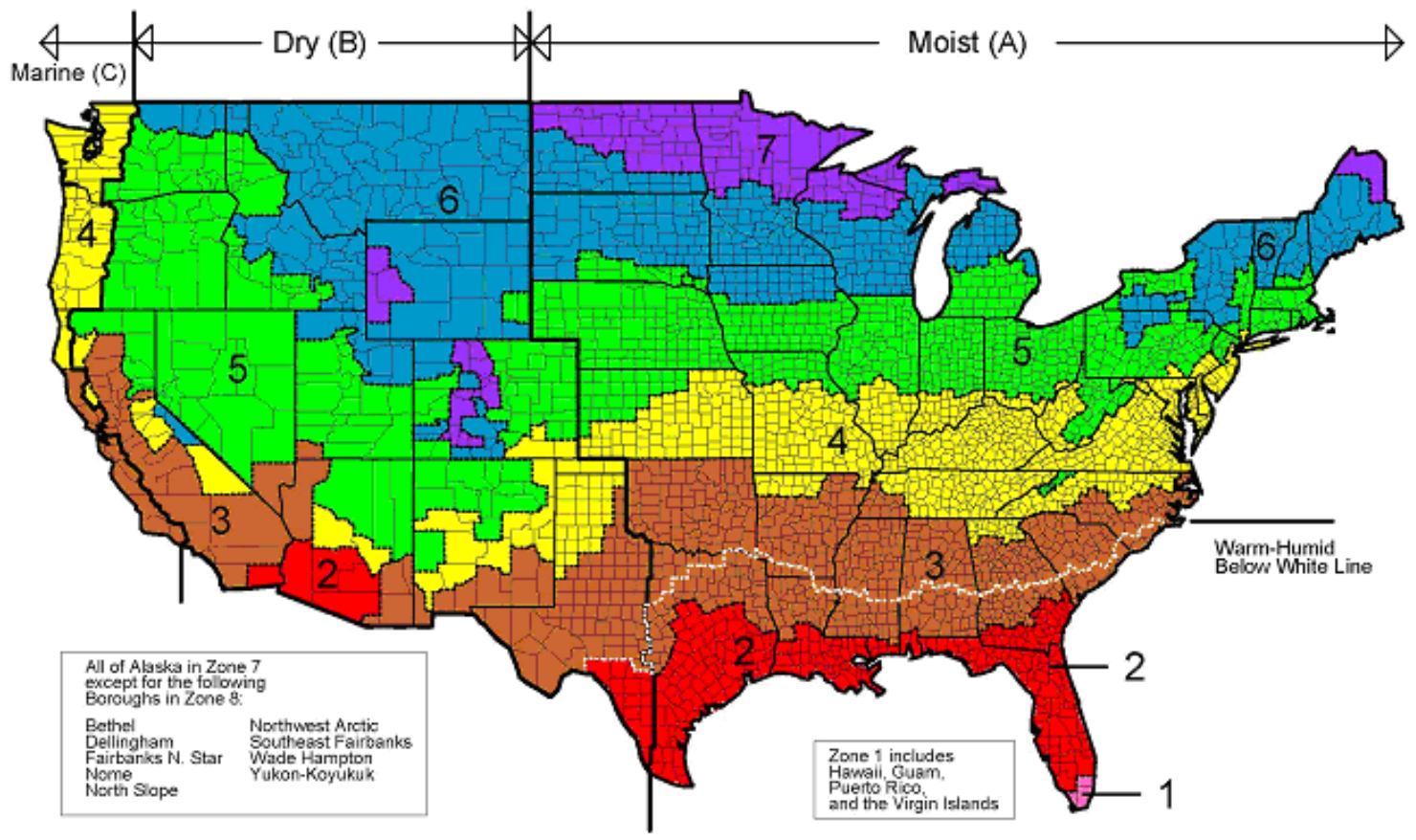

Figure 2.1. DOE-Developed Climate Zone Map

The sixteen cities representing the climate zones are:

- 1A: Miami, Florida (hot, humid)

- 2A: Houston, Texas (hot, humid)

- 2B: Phoenix, Arizona (hot, dry)

- 3A: Atlanta, Georgia (hot, humid)

- 3B-CA: Los Angeles, California (hot, dry)

- 3B-other: Las Vegas, Nevada (hot, dry)

- 3C: San Francisco, California (marine)

- 4A: Baltimore, Maryland (mild, humid)
- 4B: Albuquerque, New Mexico (mild, dry)

- 4C: Seattle, Washington (marine)

- 5A: Chicago, Illinois (cold, humid)

- 5B: Denver, Colorado (cold, dry)

- 6A: Minneapolis, Minnesota (cold, humid)

- 6B: Helena, Montana (cold, dry)

- 7: Duluth, Minnesota (very cold)

- 8: Fairbanks, Alaska (extreme cold)

These representative climate locations are assigned weights based on the square footage of construction from 2003 to 2007 as presented in a draft PNNL study which utilizes the McGraw-Hill Construction Projects Starts Database (MHC) (Jarnagin, Bandyopadhyay 2009). This study presents weighting factors for all 16 DOE benchmark building types as shown in Table 2.1 with medium office shown in bold (see section 2.4 for a description of the benchmark buildings). Table 2.2 shows just the medium office weighting factors normalized to total $100 \%$ and labeled according to the representative cities shown above. The weights for medium office by climate locations are used to calculate weighted average energy savings results for the whole country in Section 6.0 including splitting the weight in half for climate zone 3B (dry) for each of two city locations, Los Angeles and Las Vegas. 
Table 2.1. Construction Volume Weights for All ASHRAE Building Prototypes and Climate Zones

\begin{tabular}{|c|c|c|c|c|c|c|c|c|c|c|c|c|c|c|c|c|c|}
\hline No. & Prototype & 1 moist & 2 dry & 2 moist & 3 dry & $\begin{array}{c}3 \\
\text { marine }\end{array}$ & 3 moist & 4 dry & $\begin{array}{c}4 \\
\text { marine }\end{array}$ & 4 moist & 5 dry & 5 moist & 6 dry & 6 moist & 7 & 8 & National \\
\hline 1 & Large Office & $0.102 \%$ & $0.061 \%$ & $0.326 \%$ & $0.285 \%$ & $0.117 \%$ & $0.445 \%$ & $0.000 \%$ & $0.154 \%$ & $1.132 \%$ & $0.121 \%$ & $0.442 \%$ & $0.000 \%$ & $0.133 \%$ & $0.011 \%$ & $0.000 \%$ & $3.327 \%$ \\
\hline 2 & $\begin{array}{l}\text { Medium } \\
\text { Office }\end{array}$ & $0.129 \%$ & $0.292 \%$ & $0.813 \%$ & $0.715 \%$ & $0.136 \%$ & $0.766 \%$ & $0.036 \%$ & $0.196 \%$ & $1.190 \%$ & $0.342 \%$ & $1.060 \%$ & $0.035 \%$ & $0.298 \%$ & $0.033 \%$ & $0.007 \%$ & $6.047 \%$ \\
\hline 3 & Small Office & $0.084 \%$ & $0.289 \%$ & $1.064 \%$ & $0.475 \%$ & $0.078 \%$ & $0.963 \%$ & $0.047 \%$ & $0.123 \%$ & $0.936 \%$ & $0.322 \%$ & $0.920 \%$ & $0.030 \%$ & $0.241 \%$ & $0.032 \%$ & $0.005 \%$ & $5.608 \%$ \\
\hline 4 & $\begin{array}{l}\text { Standalone } \\
\text { Retail } \\
\end{array}$ & $0.224 \%$ & $0.507 \%$ & $2.220 \%$ & $1.250 \%$ & $0.191 \%$ & $2.386 \%$ & $0.119 \%$ & $0.428 \%$ & $2.545 \%$ & $0.792 \%$ & $3.429 \%$ & $0.091 \%$ & $0.948 \%$ & $0.109 \%$ & $0.014 \%$ & $15.254 \%$ \\
\hline 5 & Strip Mall & $0.137 \%$ & $0.254 \%$ & $0.991 \%$ & $0.626 \%$ & $0.103 \%$ & $1.021 \%$ & $0.023 \%$ & $0.107 \%$ & $1.008 \%$ & $0.201 \%$ & $1.023 \%$ & $0.016 \%$ & $0.153 \%$ & $0.007 \%$ & $0.001 \%$ & $5.669 \%$ \\
\hline 6 & $\begin{array}{l}\text { Primary } \\
\text { School }\end{array}$ & $0.064 \%$ & $0.164 \%$ & $0.933 \%$ & $0.446 \%$ & $0.048 \%$ & $0.944 \%$ & $0.030 \%$ & $0.094 \%$ & $0.895 \%$ & $0.224 \%$ & $0.920 \%$ & $0.037 \%$ & $0.168 \%$ & $0.023 \%$ & $0.003 \%$ & $4.994 \%$ \\
\hline 7 & $\begin{array}{l}\text { Secondary } \\
\text { School }\end{array}$ & $0.160 \%$ & $0.230 \%$ & $1.523 \%$ & $0.819 \%$ & $0.109 \%$ & $1.893 \%$ & $0.063 \%$ & $0.243 \%$ & $2.013 \%$ & $0.438 \%$ & $2.282 \%$ & $0.086 \%$ & $0.415 \%$ & $0.075 \%$ & $0.012 \%$ & $10.361 \%$ \\
\hline 8 & Hospital & $0.040 \%$ & $0.096 \%$ & $0.479 \%$ & $0.273 \%$ & $0.039 \%$ & $0.468 \%$ & $0.022 \%$ & $0.106 \%$ & $0.615 \%$ & $0.218 \%$ & $0.812 \%$ & $0.024 \%$ & $0.221 \%$ & $0.034 \%$ & $0.001 \%$ & $3.448 \%$ \\
\hline 9 & $\begin{array}{l}\text { Outpatient } \\
\text { Health Care }\end{array}$ & $0.037 \%$ & $0.134 \%$ & $0.567 \%$ & $0.275 \%$ & $0.061 \%$ & $0.581 \%$ & $0.023 \%$ & $0.181 \%$ & $0.818 \%$ & $0.218 \%$ & $1.058 \%$ & $0.033 \%$ & $0.342 \%$ & $0.039 \%$ & $0.002 \%$ & $4.371 \%$ \\
\hline 10 & Restaurant & $0.009 \%$ & $0.025 \%$ & $0.106 \%$ & $0.047 \%$ & $0.006 \%$ & $0.111 \%$ & $0.006 \%$ & $0.010 \%$ & $0.127 \%$ & $0.031 \%$ & $0.143 \%$ & $0.004 \%$ & $0.031 \%$ & $0.004 \%$ & $0.000 \%$ & $0.660 \%$ \\
\hline 11 & $\begin{array}{l}\text { Fast Food } \\
\text { Restaurant }\end{array}$ & $0.008 \%$ & $0.020 \%$ & $0.092 \%$ & $0.063 \%$ & $0.007 \%$ & $0.102 \%$ & $0.005 \%$ & $0.014 \%$ & $0.089 \%$ & $0.026 \%$ & $0.128 \%$ & $0.003 \%$ & $0.025 \%$ & $0.004 \%$ & $0.000 \%$ & $0.587 \%$ \\
\hline 12 & Large Hotel & $0.109 \%$ & $0.125 \%$ & $0.621 \%$ & $0.793 \%$ & $0.106 \%$ & $0.635 \%$ & $0.037 \%$ & $0.123 \%$ & $0.958 \%$ & $0.200 \%$ & $0.919 \%$ & $0.058 \%$ & $0.227 \%$ & $0.038 \%$ & $0.004 \%$ & $4.951 \%$ \\
\hline 13 & $\begin{array}{l}\text { Small } \\
\text { hotel/motel }\end{array}$ & $0.010 \%$ & $0.030 \%$ & $0.288 \%$ & $0.114 \%$ & $0.022 \%$ & $0.268 \%$ & $0.020 \%$ & $0.039 \%$ & $0.315 \%$ & $0.089 \%$ & $0.365 \%$ & $0.031 \%$ & $0.107 \%$ & $0.020 \%$ & $0.004 \%$ & $1.721 \%$ \\
\hline 14 & $\begin{array}{l}\text { Non- } \\
\text { refrigerated } \\
\text { warehouse } \\
\end{array}$ & $0.349 \%$ & $0.580 \%$ & $2.590 \%$ & $2.298 \%$ & $0.154 \%$ & $2.966 \%$ & $0.068 \%$ & $0.435 \%$ & $2.446 \%$ & $0.688 \%$ & $3.580 \%$ & $0.049 \%$ & $0.466 \%$ & $0.043 \%$ & $0.002 \%$ & $16.716 \%$ \\
\hline 15 & $\begin{array}{l}\text { High-rise } \\
\text { apartment }\end{array}$ & $1.521 \%$ & $0.076 \%$ & $1.512 \%$ & $0.741 \%$ & $0.173 \%$ & $0.652 \%$ & $0.000 \%$ & $0.358 \%$ & $2.506 \%$ & $0.115 \%$ & $1.163 \%$ & $0.016 \%$ & $0.125 \%$ & $0.008 \%$ & $0.000 \%$ & $8.967 \%$ \\
\hline \multirow[t]{2}{*}{16} & $\begin{array}{l}\text { Mid-rise } \\
\text { apartment }\end{array}$ & $0.257 \%$ & $0.093 \%$ & $1.094 \%$ & $0.862 \%$ & $0.260 \%$ & $0.825 \%$ & $0.022 \%$ & $0.371 \%$ & $1.694 \%$ & $0.318 \%$ & $1.122 \%$ & $0.056 \%$ & $0.313 \%$ & $0.032 \%$ & $0.000 \%$ & $7.321 \%$ \\
\hline & Totals & $3.242 \%$ & $2.975 \%$ & $15.217 \%$ & $10.081 \%$ & $1.609 \%$ & $15.025 \%$ & $0.522 \%$ & $2.981 \%$ & $19.286 \%$ & $4.344 \%$ & $19.366 \%$ & $0.569 \%$ & $4.214 \%$ & $0.513 \%$ & $0.056 \%$ & $100.0 \%$ \\
\hline
\end{tabular}

Table 2.2. Construction Weights for Medium Office

\begin{tabular}{|c|c|c|c|c|c|c|c|c|c|c|c|c|c|c|c|c|}
\hline $\begin{array}{c}1 \mathrm{~A} \\
\text { Miami }\end{array}$ & $\begin{array}{c}2 \mathrm{~A} \\
\text { Houston }\end{array}$ & $\begin{array}{c}\text { 2B } \\
\text { Phoen } \\
\text { ix }\end{array}$ & $\begin{array}{c}3 \mathrm{~A} \\
\text { Atlanta } \\
\end{array}$ & $\begin{array}{c}\text { 3B-CA } \\
\text { Los } \\
\text { Angeles }\end{array}$ & $\begin{array}{c}\text { 3B- } \\
\text { other } \\
\text { Las } \\
\text { Vegas }\end{array}$ & $\begin{array}{c}3 \mathrm{C} \\
\text { San } \\
\text { Francisco }\end{array}$ & $\begin{array}{c}4 \mathrm{~A} \\
\text { Baltimore } \\
\end{array}$ & $\begin{array}{c}4 \mathrm{~B} \\
\text { Albuquerque }\end{array}$ & $\begin{array}{c}4 \mathrm{C} \\
\text { Seattle } \\
\end{array}$ & $\begin{array}{c}5 \mathrm{~A} \\
\text { Chicago } \\
\end{array}$ & $\begin{array}{c}\text { 5B } \\
\text { Denver }\end{array}$ & $\begin{array}{c}6 \mathrm{~A} \\
\text { Minneapolis } \\
\end{array}$ & $\begin{array}{c}6 \mathrm{~B} \\
\text { Helena } \\
\end{array}$ & $\begin{array}{c}7 \\
\text { Duluth }\end{array}$ & $\begin{array}{c}8 \\
\text { Fairbanks } \\
\end{array}$ & Total \\
\hline $2.13 \%$ & $13.44 \%$ & $4.83 \%$ & $12.67 \%$ & $5.91 \%$ & $5.91 \%$ & $2.25 \%$ & $19.68 \%$ & $0.60 \%$ & $3.24 \%$ & $17.53 \%$ & $5.66 \%$ & $4.93 \%$ & $0.58 \%$ & $0.55 \%$ & $0.12 \%$ & $100 \%$ \\
\hline
\end{tabular}




\subsection{Development of the Medium Office Prototype Building}

The first step of the energy savings analysis is the development of a prototype building. The medium office prototype used for this document is based on the US Department of Energy's benchmark building series. DOE's Building Technologies Program, working with DOE's Pacific Northwest National Laboratory, Lawrence Berkeley National Laboratory, and National Renewable Energy Laboratory, developed models for 16 commercial building types in 16 locations representing all U.S. climate zones. These 16 building types cover about $70 \%$ of the commercial buildings in the United States.

The benchmark buildings were developed with information from many sources including the Commercial Building Energy Consumption Survey (CBECS), and work done by the national labs and others on previous Advanced Energy Design Guides and supporting analysis for the development of the 90.1 Standard. The CBECS data sets are publicly available and provide statistically valid results from a periodic national survey of commercial buildings and their energy suppliers. The study considers new buildings and CBECS covers existing buildings but remains useful as many new building characteristics are consistent with past practice. The CBECS data can provide information about common characteristics of buildings, critical to the prototypical building development.

There are three sets of benchmark buildings representing new construction, post-1980 construction, and pre-1980 construction. The benchmarks were developed to represent more realistic buildings and typical construction practices and follow the minimum requirements of Standard 90.1 but do not always follow the 90.1 Appendix G modeling rules. The medium office analysis is based on the new construction benchmark, consistent with a Standard 90.1-2004 baseline.

Additional Information on these benchmark buildings is available at the US Department of Energy's Energy Efficiency and Renewable Energy news site, and there is another link there that allows anyone to download four components of the national benchmarks.

- An EnergyPlus input file (.idf)

- An HTML file showing the results from the EnergyPlus simulation (.html)

- A scorecard summarizing the inputs and results for each location (.pdfs)

- Appropriate weather data file for EnergyPlus (.epw).

The website address is: http://apps1.eere.energy.gov/news/progress_alerts.cfm/pa_id=132

Tables in Appendix A summarize the building characteristics for the medium office prototype. These inputs were used for developing baseline building models and advanced building models, which are described in Section 4.0 and 5.0, respectively. 


\subsection{Development of Baseline Building Model and Assumptions}

This section summarizes the development of the Medium Office Building baseline models. Many of the assumptions that are used for this analysis originated from PNNL's work on the Advanced Energy Design Guide for Small Office Buildings (Jarnagin et al. 2006), the development of the DOE benchmark building series (DOE 2008), and the creation of prototype building models that are being used to support the development of ASHRAE Standard 90.1.

The baseline medium office prototype building is a theoretical building modeled with characteristics typical of buildings of this size and use. The medium office building is a 53,600 $\mathrm{ft}^{2}\left(4,980 \mathrm{~m}^{2}\right)$ three-story building. The building is rectangular shaped, $164 \mathrm{ft}(50 \mathrm{~m})$ by $109 \mathrm{ft}(33 \mathrm{~m})$ (aspect ratio 1.5). Building components regulated by ASHRAE Standard 90.1- 2004 are assumed to "just meet" the minimum prescriptive requirements of that standard. Components not regulated by Standard 90.1 are assumed to be designed as is standard practice for a medium office building. Standard practice is determined from various sources including a review of the Commercial Buildings Energy Consumption Survey (CBECS 2003) and the input of various design and construction industry professionals. The following sections include a topic-by-topic review of the baseline building and how the baseline building is simulated in EnergyPlus, including characteristics of the building envelope, building internal loads (people, lighting, miscellaneous equipment, and infiltration), HVAC equipment, and service water heating.

\subsection{Building Operating Characteristics}

The building is assumed to follow typical office occupancy patterns with peak occupancy occurring from 8 AM to 5 PM weekdays with limited occupancy beginning at 6 AM and extending until midnight for janitorial functions. For the medium office, Saturday occupancy is modeled at $10-30 \%$ of peak and limited Sunday and holiday occupancy (approximately 5\%) is assumed. Schedules for lighting and miscellaneous equipment were matched to occupancy schedules with additional limited usage during unoccupied times. HVAC system schedules were matched to the occupancy schedules, and allow for earlier startup times to bring the space to the desired temperature at the beginning of normal occupancy. These schedules are similar to schedules published in ASHRAE/IESNA Standard 90.1-1989 (ASHRAE/IESNA 1989). Figure 3.1 illustrates the typical weekday schedules for occupancy, lighting equipment and HVAC fans for the medium office, as simulated in EnergyPlus. 


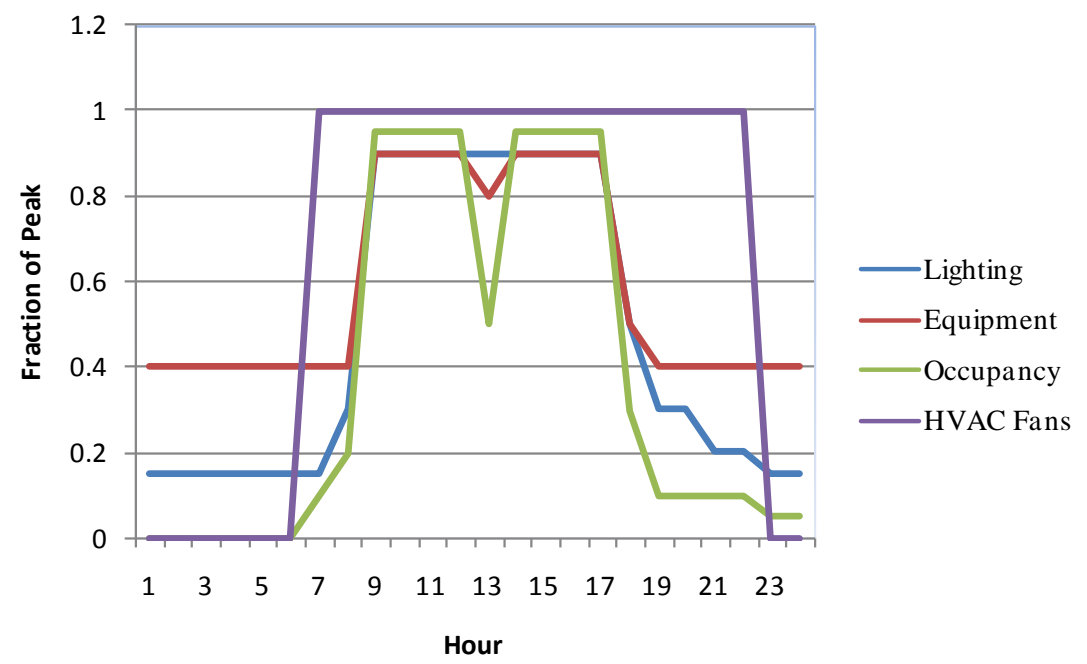

Figure 3.1. Medium Office Weekday Schedules

\subsection{Baseline Building Envelope Characteristics}

Building opaque constructions include steel-framed walls, flat roof with insulation above the deck and slab-on-grade floors. These envelope structures represent common construction practice for medium office buildings in the U.S. based on information from the CBECS data. Figure 3.2 shows an axonometric view of the building as input in the energy simulation model.

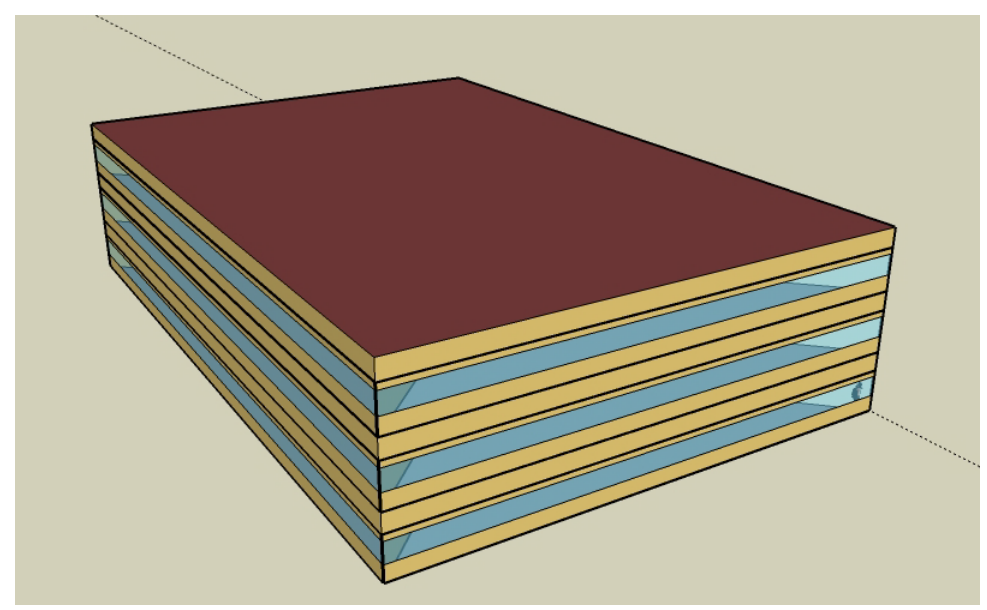

Figure 3.2. Axonometric View of Medium Office Building

The baseline building envelope characteristics were developed to meet the prescriptive design option requirements of ASHRAE Standard 90.1-2004 Section 5.3 Prescriptive Building Envelope Option (ANSI/ASHRAE/IESNA 2004a). The EnergyPlus program can calculate the U-factor of opaque assemblies by defining the properties of materials, layers and construction. This method was used in this analysis to properly account for thermal mass impacts on the calculations of space loads. The following section describes the assumptions used for modeling the baseline building envelope components, including the exterior walls, roofs, slab-on-grade floors, fenestration, infiltration, and roof absorptance. 


\subsubsection{Exterior Walls}

The exterior walls of the medium office prototype are steel framed with stucco exterior cladding. There is fiberglass batt insulation within the stud cavity and additional rigid insulation when needed to meet climate zone specific requirements. The exterior wall includes the following layers:

- Exterior air film, $\mathrm{R}=0.17 \mathrm{ft}^{2} \cdot \mathrm{F} \cdot \mathrm{h} / \mathrm{Btu}\left(0.03 \mathrm{~K} \cdot \mathrm{m}^{2} / \mathrm{W}\right)$

- 0.75 -in. $(19 \mathrm{~mm})$ thick stucco, $\mathrm{R}=0.08 \mathrm{ft}^{2} \cdot \mathrm{F} \cdot \mathrm{h} / \mathrm{Btu}\left(0.01 \mathrm{~K} \cdot \mathrm{m}^{2} / \mathrm{W}\right)$

- 0.625-in. $(16 \mathrm{~mm})$ thick gypsum board, $\mathrm{R}=0.56 \mathrm{ft}^{2} \cdot \mathrm{F} \cdot \mathrm{h} / \mathrm{Btu}\left(0.10 \mathrm{~K} \cdot \mathrm{m}^{2} / \mathrm{W}\right)$

- 2-in x 4-in (50 mm x $100 \mathrm{~mm})$ steel studs @ 16-in (400 mm) on center with R=13 ft ${ }^{2} \cdot \mathrm{F} \cdot \mathrm{h} / \mathrm{Btu}(2.3$ $\mathrm{K} \cdot \mathrm{m}^{2} / \mathrm{W}$ ) fiberglass batt insulation in stud cavity

- Additional board insulation (varies by climate)

- 0.625-in. $(16 \mathrm{~mm})$ thick gypsum board, $\mathrm{R}=0.56 \mathrm{ft}^{2} \cdot \mathrm{F} \cdot \mathrm{h} / \mathrm{Btu}\left(0.10 \mathrm{~K} \cdot \mathrm{m}^{2} / \mathrm{W}\right)$

- Interior air film, $\mathrm{R}=0.68 \mathrm{ft}^{2} \cdot \mathrm{F} \cdot \mathrm{h} / \mathrm{Btu}\left(0.12 \mathrm{~K} \cdot \mathrm{m}^{2} / \mathrm{W}\right)$

$\mathrm{R}$-values for most of the above layers were derived from Appendix A (Rated R-Value of Insulation and Assembly U-Factor, C-Factor, And F-Factor Determination) of the Standard. Insulation R-values were selected to create a wall assembly that just meets the maximum U-value required in Tables 5.5.1 through 5.5.8 of the Standard (ANSI/ASHRAE/IESNA 2004a) for different climate zones.

\subsubsection{Roofs}

The medium office building prototype uses a flat roof that consists of a roof membrane over rigid insulation, uninterrupted by framing, over a structural metal deck. Roof insulation R-values were also set to match the maximum roof U-value requirements in Tables 5.5.1 through 5.5.8 of the Standard (ANSI/ASHRAE/IESNA 2004a) for different climate zones. The roof construction is defined with the following layers:

- Exterior air film, $\mathrm{R}=0.17 \mathrm{ft}^{2} \cdot \mathrm{F} \cdot \mathrm{h} / \mathrm{Btu}\left(0.03 \mathrm{~K} \cdot \mathrm{m}^{2} / \mathrm{W}\right)$

- Continuous rigid insulation (thickness and R-value vary by climate)

- Metal deck, $\mathrm{R}=0$

- Interior air film heat flow up, $\mathrm{R}=0.61 \mathrm{ft}^{2} \cdot \mathrm{F} \cdot \mathrm{h} / \mathrm{Btu}\left(0.11 \mathrm{~K} \cdot \mathrm{m}^{2} / \mathrm{W}\right)$

The Standard does not specify either roof reflectivity or emittance. In the baseline prototypes, the roof exterior finish was chosen as a single-ply roof membrane of grey EPDM (ethylene propylene diene terpolymer membrane). From a cool roofing materials database by the Lawrence Berkeley National Laboratory (LBNL 2009), the solar reflectance and the thermal emittance of the EPDM was defined respectively as 0.23 and 0.87 .

\subsubsection{Slab-On-Grade Floors}

The base assembly for the ground floor in the medium office prototype is carpet over $6 \mathrm{in}$. (150 mm) concrete slab floor poured directly on to the earth (slab-on-grade). Modeled below the slab is 12 in. $(300 \mathrm{~mm})$ soil, with soil conductivity of $0.75 \mathrm{Btu} / \mathrm{ft}^{2} \cdot \mathrm{F} \cdot \mathrm{h}\left(1.3 \mathrm{~W} / \mathrm{m}^{2} \mathrm{~K}\right)$. In contrast to the U-factor for other envelope assemblies, the F-factor is set to match the minimum requirements for unheated slab-ongrade floors in Tables 5.5.1 through 5.5.8 of Standard 90.1, based on climate. F-factor is expressed as the conductance of the surface per unit length of building perimeter. Chapter 5 of the Standard also provides the corresponding R-values of the vertical insulation when required (e.g., in climate zone 8). This 
continuous insulation is typically applied directly to the slab exterior, extending downward from the top of the slab for the distance specified in the tables.

One of the advanced features of the EnergyPlus program is that the conduction calculations of the ground heat-transfer through ground-contact surfaces (i.e., slab-on-grade floors) are two- or threedimensional rather than the simplified one-dimensional as in other simulation programs (i.e., DOE-2). To use this method, the appropriate ground temperature is determined by the Slab program, a preprocessor that is one of the Auxiliary EnergyPlus programs. Then the calculated custom monthly average ground temperatures were manually transferred directly into EnergyPlus for each of 15 climate locations.

The Slab program requires the following key inputs to calculate the ground temperatures:

- Slab material and soil density

- Building height

- Indoor average temperature set point

- R-value and depth of vertical insulation (if presented)

- Thickness of slab-on-grade

- The floor area to perimeter length ratio for this slab

- Distance from edge of slab to domain edge.

\subsubsection{Fenestration}

Medium-sized office buildings generally have moderate window-to-wall ratios (WWR), usually in the $20 \%$ to 30\% range according to the CBECS 2003 data (CBECS 2003). The overall WWR of the entire building used in the modeling was chosen as $33 \%$ for the medium office. The windows have an height of $4 \mathrm{ft}(1.22 \mathrm{~m})$ and are distributed evenly in continuous ribbons around the perimeter of the building.

Chapter 5 of Standard 90.1- 2004 lists U-factor and solar heat gain coefficient (SHGC) requirements based on climate zone, window-to-wall ratio, and window operator type (fixed or operable). Based on an estimated weighting of $4.6 \%$ operable and $95.4 \%$ fixed windows ${ }^{1}$, a baseline window U-factor and solar heat gain coefficient are determined to match the fenestration performance criteria outlined in Tables 5.5.1 through 5.5.8 of the Standard (ANSI/ASHRAE/IESNA 2004a) for different climate zones.

Based on CBECS, the primary fenestration type in medium office buildings is curtain wall and storefront. The baseline and later the advanced performance values are consistent with these types of window systems. Buildings with fixed frame windows can achieve lower U-factors because of lower frame conductance.

Although window requirements in the Standard are defined by the overall properties of U-factor and SHGC, EnergyPlus requires that the thermal/optical properties are defined for the window assembly layer by layer. It is a challenge to manually find a hypothetical window construction that matches given $U$ and SHGC values exactly. To address the above challenge, a simplified strategy was used to find the closest match of a window construction in the EnergyPlus window library for given U and SHGC values. In the matching process, a close match to the SHGC value is regarded as a more important criterion for climate

\footnotetext{
${ }^{1}$ ASHRAE SSPC 90.1 Envelope Subcommittee provided the estimated weighting factor based on the Ducker Fenestration Market Data.
} 
zones 1-3, where cooling load is a major consideration. On the other hand, a close match to the U-value is a more important criterion for climate zones 4 through 8 , where heating load is the major consideration. Because only a close match can be found, there is a minor deviation between the modeled U and SHGC values and the target values.

Table 3.1 lists the target and actual performance for the selected window constructions in the baseline case. The effects of window frame and dividers are not modeled explicitly.

Table 3.1. Fenestration U-Factor and SHGC Values for the Baseline Models

\begin{tabular}{|c|c|c|c|c|}
\hline \multirow[b]{3}{*}{ Climate Zone } & \multicolumn{4}{|c|}{ Baseline } \\
\hline & \multicolumn{2}{|c|}{ Target Values } & \multicolumn{2}{|c|}{ Actual Values } \\
\hline & $\begin{array}{c}\text { U-factor } \\
\text { Btu/h } / \mathrm{ft}^{2} \cdot \mathrm{F} \\
\left(\mathrm{W} / \mathrm{m}^{2} \cdot \mathrm{K}\right)\end{array}$ & SHGC & $\begin{array}{c}\text { U-factor } \\
\text { Btu/h } \cdot \mathrm{ft}^{2} \cdot \mathrm{F} \\
\left(\mathrm{W} / \mathrm{m}^{2} \cdot \mathrm{K}\right)\end{array}$ & SHGC \\
\hline 1 & $\begin{array}{c}1.22 \\
(6.92)\end{array}$ & 0.25 & $\begin{array}{c}1.08 \\
(6.13)\end{array}$ & 0.28 \\
\hline 2 & $\begin{array}{c}1.22 \\
(6.92)\end{array}$ & 0.25 & $\begin{array}{c}1.08 \\
(6.13)\end{array}$ & 0.28 \\
\hline $3 \mathrm{~A}, 3 \mathrm{~B}$ & $\begin{array}{c}0.57 \\
(3.23)\end{array}$ & 0.25 & $\begin{array}{c}0.51 \\
(2.89)\end{array}$ & 0.28 \\
\hline $3 \mathrm{C}$ & $\begin{array}{c}1.22 \\
(6.92)\end{array}$ & 0.34 & $\begin{array}{c}0.94 \\
(5.33)\end{array}$ & 0.34 \\
\hline 4 & $\begin{array}{c}0.57 \\
(3.23)\end{array}$ & 0.39 & $\begin{array}{c}0.55 \\
(3.12)\end{array}$ & 0.43 \\
\hline 5 & $\begin{array}{c}0.57 \\
(3.23)\end{array}$ & 0.39 & $\begin{array}{c}0.55 \\
(3.12)\end{array}$ & 0.43 \\
\hline 6 & $\begin{array}{c}0.57 \\
(3.23)\end{array}$ & 0.39 & $\begin{array}{c}0.55 \\
(3.12)\end{array}$ & 0.43 \\
\hline 7 & $\begin{array}{c}0.57 \\
(3.23)\end{array}$ & 0.49 & $\begin{array}{c}0.55 \\
(3.12)\end{array}$ & 0.5 \\
\hline 8 & $\begin{array}{c}0.46 \\
(2.61)\end{array}$ & NR & $\begin{array}{c}0.48 \\
(2.72)\end{array}$ & 0.47 \\
\hline
\end{tabular}

In addition to U-factor and SHGC, the simulation accounts for visible light transmittance (VLT). VLT has no direct impact on building loads or energy consumption, and there is no prescriptive requirement for VLT in Standard 90.1. However, VLT will impact the performance of daylighting systems. For the baseline fenestration, VLT values are simply based on the window constructions in the EnergyPlus window library that meet the desired U-factor and SHGC.

\subsection{Air Infiltration}

The Standard does not specify a requirement for maximum air infiltration rate. Building air infiltration is addressed only indirectly in the Standard through the requirements for building envelope sealing, fenestration and door air leakage, etc. For this analysis, the infiltration rate was assumed to be $1.8 \mathrm{cfm} / \mathrm{ft}^{2}\left(9.14 \mathrm{E}-3 \mathrm{~m}^{3} / \mathrm{s} \cdot \mathrm{m}^{2}\right)$ of above-grade envelope surface area at $0.3 \mathrm{in}$. w.c. (75 Pa) based on the study by the National Institute of Standards and Technologies (Emmerich et al. 2005).

The EnergyPlus program offers three methods for addressing infiltration: the constant infiltration method (EnergyPlus default); the DOE-2 methodology which accounts for wind-driven pressure 
differences; and the BLAST methodology which accounts for both wind-driven and stack-driven pressure differences. Based on the results of PNNL's study on infiltration modeling methodology, the DOE-2 method was utilized.

PNNL has developed the following methodology to convert the infiltration rate at 0.3 in. w.c. (75 Pa) to a corresponding wind-driven design infiltration rate input in EnergyPlus:

Step 1: Calculate the average wind-driven building pressure on all walls of a building with a wind velocity calculated at the roof line and normal to one wall of the building using existing wind pressure formulations (Swami and Chandra 1987).

Step 2: Integrate the positive wind-driven building pressure for all angles of wind to get an average positive wind pressure across all wall surfaces as a function of wind velocity. (This step is necessary because the wind speed correlations in EnergyPlus are independent of direction)

Step 3: Calculate the infiltration in the building at an average surface pressure from Step 2 and a reference wind speed at the roof line (e.g., $10 \mathrm{mph}$ ) by multiplying the infiltration at 0.3 in. w.c. (75 Pa) whole building pressure difference by the ratio of the average wind pressure from Step 2 to 0.3 in. w.c. (75 Pa), as modified using a flow exponent 0.65 . This provides the average infiltration rate across the wall surfaces based on the wind speed measured at the roof line.

Step 4: Adjust the calculated infiltration rate from Step 3 so that it can be correctly used as EnergyPlus input by multiplying it by the ratio of the wind speed at the roof line to the average wind speed impinging on a building wall with outward surface normal anti-parallel to the wind direction. This ratio can be calculated using a power-law wind profile based on the same site terrain as in the EnergyPlus model. (This is necessary because the infiltration calculations in EnergyPlus use the wind speed at the center height of each exterior wall above ground.)

Following the above methodology, the EnergyPlus input design infiltration is calculated as $0.2016 \mathrm{cfm} / \mathrm{ft}^{2}\left(1.02 \mathrm{E}-3 \mathrm{~m}^{3} / \mathrm{s} \cdot \mathrm{m}^{2}\right)$ of above-grade exterior wall surface area, equivalent to the base infiltration rate of $1.8 \mathrm{cfm} / \mathrm{ft}^{2}\left(9.14 \mathrm{E}-3 \mathrm{~m} / 3 \cdot \mathrm{s} \cdot \mathrm{m}^{2}\right)$ of above-grade envelope surface area at $0.3 \mathrm{in}$. w.c. (75 Pa).

In addition, an infiltration schedule is input in EnergyPlus to vary the peak infiltration rate calculated above with HVAC fan on/off operation. The schedule assumes full infiltration when the HVAC system is scheduled "off” and 25\% infiltration when the HVAC system is switched "on".

\subsection{Internal and External Loads}

Internal loads include heat generated from occupants, lights, and miscellaneous equipment (elevator and plug loads such as computers, printers, small beverage machines, etc.). In this study, external loads refer to the exterior lighting energy use only. Modeling the energy impacts of the building internal loads using the EnergyPlus simulation program requires assumptions about the building internal load intensity and operation schedules. For the occupancy loads, the load intensity refers to the peak occupancy for a typical day. For lighting and plug loads, these loads are represented by the peak power density. 
Internal load schedules were developed from schedules previously used in work for the Department of Energy on the Commercial Equipment Standards program. Additional data on occupancy was derived from ASHRAE Standard 62.1-2004 (ANSI/ASHRAE 2004). Figure 3.1 shows a graph of the typical weekday schedule profiles for each of the three internal load categories (plugs, lights and occupancy).

\subsubsection{People}

The value of the peak occupancy for the medium office building, five persons per $1000 \mathrm{ft}^{2}\left(93 \mathrm{~m}^{2}\right)$ of gross floor area was assumed based on modeling assumptions in the user's manual for ANSI/ASHRAE/IESNA Standard 90.1-2004 (ANSI/ASHRAE/IESNA 2004b). This results in the total of 268 people for the medium office building.

For the computer simulations, the total heat gain is set at $450 \mathrm{Btu} / \mathrm{hr}(132 \mathrm{~W})$ per person, based on $250 \mathrm{Btu} / \mathrm{hr}(74 \mathrm{~W})$ sensible heat gain and $200 \mathrm{Btu} / \mathrm{hr}(58 \mathrm{~W})$ latent heat gain. These values are based on the degree of activity in offices, i.e., standing, light work and walking, and were derived from Table 1 of Chapter 30 in the ASHRAE 2005 Fundamentals Handbook (ASHRAE 2005), and assumes that the occupant activity does not vary with climate.

\subsubsection{Interior Lighting}

The baseline lighting system is assumed to be a system that just meets the lighting power density requirements of Table 9.5.1, Lighting Power Densities Using the Building Area Method of ASHRAE Standard 90.1- 2004. Ambient lighting power density for the entire building is input at an average of $1.0 \mathrm{~W} / \mathrm{ft}^{2}\left(10.76 \mathrm{~W} / \mathrm{m}^{2}\right)$ for all areas. Standard 90.1 also includes various mandatory interior lighting control requirements including building-wide automatic shutoff and occupancy sensor control in some locations likely to be found in office buildings including conference rooms, meeting rooms, and break rooms. Mandatory controls are not explicitly simulated because the lighting diversity schedule is assumed to have considered these mandatory controls. Figure 3.1 shows the typical weekday lighting schedule with $15 \%$ of lights energized during unoccupied hours (also true for weekends and holidays).

\subsubsection{Exterior Lighting}

The building model assumes exterior lighting on the building façade, at entrances and exits, and for the parking area. Standard 90.1-2004 provides maximum lighting power allowances for each of these areas. The lighting power is based on Watts per lineal foot or Watts per square foot depending on the area type. There is also an additional allowance of $5 \%$ of the total exterior connected load to be used anywhere on the exterior. As shown in Table 3.2 the total connected exterior lighting load is calculated as $20.7 \mathrm{~kW}$ for the medium office building. The calculation is based on a number of inputs such as the percentage of parking areas, the number of main entrances and other doors, and the percentage of lightened area for each façade. These inputs are from a variety of sources including a building database (Richman et al. 2008), the Internet (e.g., Village of Wheeling 2009) and survey results (Richman 2008). 
Table 3.2. Exterior Lighting Power Allowances

\begin{tabular}{|c|c|c|}
\hline \multirow[t]{2}{*}{ Items } & \multicolumn{2}{|c|}{ Baseline } \\
\hline & (IP units) & (SI units) \\
\hline \multicolumn{3}{|l|}{ Parking } \\
\hline parking area, $\mathrm{ft}^{2}\left(\mathrm{~m}^{2}\right)^{[1]}$ & 87,480 & 8,126 \\
\hline lighting power allowance for parking $\mathrm{W} / \mathrm{ft}^{2}\left(\mathrm{~W} / \mathrm{m}^{2}\right)$ & 0.15 & 1.6 \\
\hline total lighting power for parking, W (W) & 13,122 & 13,122 \\
\hline \multicolumn{3}{|l|}{ Walkways } \\
\hline walkway area, $\mathrm{ft}^{2}\left(\mathrm{~m}^{2}\right)^{[2]}$ & 4374 & 406 \\
\hline lighting power allowance for walkway area $\mathrm{W} / \mathrm{ft}^{2}\left(\mathrm{~W} / \mathrm{m}^{2}\right)$ & 0.2 & 2.2 \\
\hline total lighting power for walkway area W (W) & 875 & 875 \\
\hline \multicolumn{3}{|l|}{ Building entrance and exits ${ }^{[3]}$} \\
\hline \multicolumn{3}{|l|}{ main entries } \\
\hline linear foot of door width for main entries, ft (m) & 16.2 & 4.9 \\
\hline lighting power allowance for main entries $\mathrm{W} / \mathrm{ft}(\mathrm{W} / \mathrm{m})$ & 30 & 98 \\
\hline canopy over entry, $\mathrm{ft}^{2}\left(\mathrm{~m}^{2}\right)$ & 48 & 4.5 \\
\hline lighting power allowance for canopy $\mathrm{W} / \mathrm{ft}^{2}\left(\mathrm{~W} / \mathrm{m}^{2}\right)$ & 1.25 & 13 \\
\hline total lighting power for main entries W (W) & 546 & 546 \\
\hline \multicolumn{3}{|l|}{ other doors } \\
\hline linear foot of door width for other doors, ft (m) & 40.7 & 12.4 \\
\hline lighting power allowance for other doors $\mathrm{W} / \mathrm{ft}(\mathrm{W} / \mathrm{m})$ & 20 & 66 \\
\hline canopy over entry $\mathrm{ft}^{2}\left(\mathrm{~m}^{2}\right)$ & 65 & 6.0 \\
\hline lighting power allowance for canopy $\mathrm{W} / \mathrm{ft}^{2}\left(\mathrm{~W} / \mathrm{m}^{2}\right)$ & 1.25 & 13.5 \\
\hline total lighting power for other doors W (W) & 895 & 895 \\
\hline total lighting power for building entrance and exits W (W) & 1,441 & 1,441 \\
\hline \multicolumn{3}{|l|}{ Building facades } \\
\hline façade area lighted $\mathrm{ft}^{2}\left(\mathrm{~m}^{2}\right)$ & 21,294 & 1,978 \\
\hline lighting power allowance for building facades $\mathrm{W} / \mathrm{ft}^{2}\left(\mathrm{~W} / \mathrm{m}^{2}\right)$ & 0.2 & 2.2 \\
\hline total lighting power for building facades W (W) & 4,259 & 4,259 \\
\hline Sum of lighting power for parking, building entrance and facades W (W) & 19,697 & 19,697 \\
\hline 5\% additional allowance $\mathrm{W}(\mathrm{W})$ & 985 & 985 \\
\hline Total exterior lighting power $\mathrm{W}(\mathrm{W})$ & 20,682 & 20,682 \\
\hline
\end{tabular}

Notes:

1. There are four parking spots per $1000 \mathrm{ft}^{2}\left(92.9 \mathrm{~m}^{2}\right)$ of building area. Each parking spot occupies $405 \mathrm{ft}^{2}(37.6$ $\mathrm{m}^{2}$ ) including associated drives.

2. Walkways are assumed to be $5 \%$ of the building square footage. Determined from site plans used in Standard 90.1-2007 addenda $I$ analysis.

3. There are about 3.5 doors per $10,000 \mathrm{ft}^{2}\left(929 \mathrm{~m}^{2}\right)$ of building area: one is the main entrance and the rest are other doors. All doors have a width of $3 \mathrm{ft}(0.29 \mathrm{~m})$.

Standard 90.1-2004 requires that exterior lighting shall have automatic controls capable of turning exterior lighting off when sufficient daylight is available or when lighting is not required (i.e., during 
nighttime hours). Use of an astronomical time switch or a photo-sensor is required for all exterior lighting. The EnergyPlus model simulates the use of an astronomical time switch, which illuminates the exterior lights when they are scheduled on and when it is expected to be dark outside.

\subsubsection{Miscellaneous Equipment (Plug Loads)}

Office buildings generally have appliance (plug) loads, normally associated with office equipment (computers, monitors, copiers, fax machines and printers, etc.); refrigerators; coffee makers; and beverage vending machines. The plug loads not only increase the electrical energy use, but have impacts on the heating and cooling energy use as well. Plug loads usually increase space cooling energy and reduce space heating energy.

Previous energy analysis work by Pacific Northwest National Laboratory (PNNL 2004) indicates that the peak plug loads for offices range from $0.2 \mathrm{~W} / \mathrm{ft}^{2}\left(2.15 \mathrm{~W} / \mathrm{m}^{2}\right)$ to $0.8 \mathrm{~W} / \mathrm{ft}^{2}\left(8.61 \mathrm{~W} / \mathrm{m}^{2}\right)$, with most falling in the range from 0.6 to $0.8 \mathrm{~W} / \mathrm{ft}^{2}\left(6.46\right.$ to $\left.8.61 \mathrm{~W} / \mathrm{m}^{2}\right)$. Off-hour base load lies in the range from 0.0 to $0.4 \mathrm{~W} / \mathrm{ft}^{2}\left(4.31 \mathrm{~W} / \mathrm{m}^{2}\right)$, with many falling near $0.3 \mathrm{~W} / \mathrm{ft}^{2}\left(3.23 \mathrm{~W} / \mathrm{m}^{2}\right)$. To determine the plug load density, a break-down plug load calculations were developed for the medium office building in accordance with ASHRAE's recommended heat gains from various office equipment and appliances (ASHRAE 2005). As shown in Table 3.3, the peak miscellaneous load for the medium office prototype is $0.75 \mathrm{~W} / \mathrm{ft}^{2}\left(8.07 \mathrm{~W} / \mathrm{m}^{2}\right)$. The off-hour load takes the values of $0.30 \mathrm{~W} / \mathrm{ft}^{2}\left(3.23 \mathrm{~W} / \mathrm{m}^{2}\right)$, which is assumed to be $40 \%$ of the peak. The above assumption is specified by the user's manual for ANSI/ASHRAE/IESNA Standard 90.1-2004.

The typical office building plug profile is the classic hat-shaped profile, with a single peak period occurring for most of the business hours and a much lower off-hour period (Figure 3.1).

\subsection{Baseline Building HVAC Systems}

Based on an analysis of CBECS data, it was determined that office buildings with the size of the medium office prototype primarily use packaged rooftop variable air volume (VAV) heating and air conditioning equipment. The study indicated about half of the buildings use gas furnace heat at the main air handler with electric resistance reheat and half use hydronic heat for the main air handler and the reheat coils. Based on the recommendation of ASHRAE Standard 90.1 Mechanical Subcommittee, the gas furnace with electric reheat option was chosen for this prototype.

\subsubsection{Building HVAC Operating Schedules}

The HVAC system operating schedule is based on the building occupancy. The system is scheduled "on" 1 hour prior to occupancy to pre-condition the space, and the system is scheduled "off" 1 hour after most occupants leave (Figure 3.1). When the system is "on”, the fan runs continuously to supply the required ventilation air, while the compressor and furnace cycle on and off to meet the building's cooling and heating loads. During off hours, the system will shut off and only cycle "on" when the setback thermostat control calls for heating or cooling to maintain the setback temperature. A single HVAC system schedule is used for all the packaged units in the building. 
Table 3.3. Plug Load Density Calculations for the Baseline Prototype

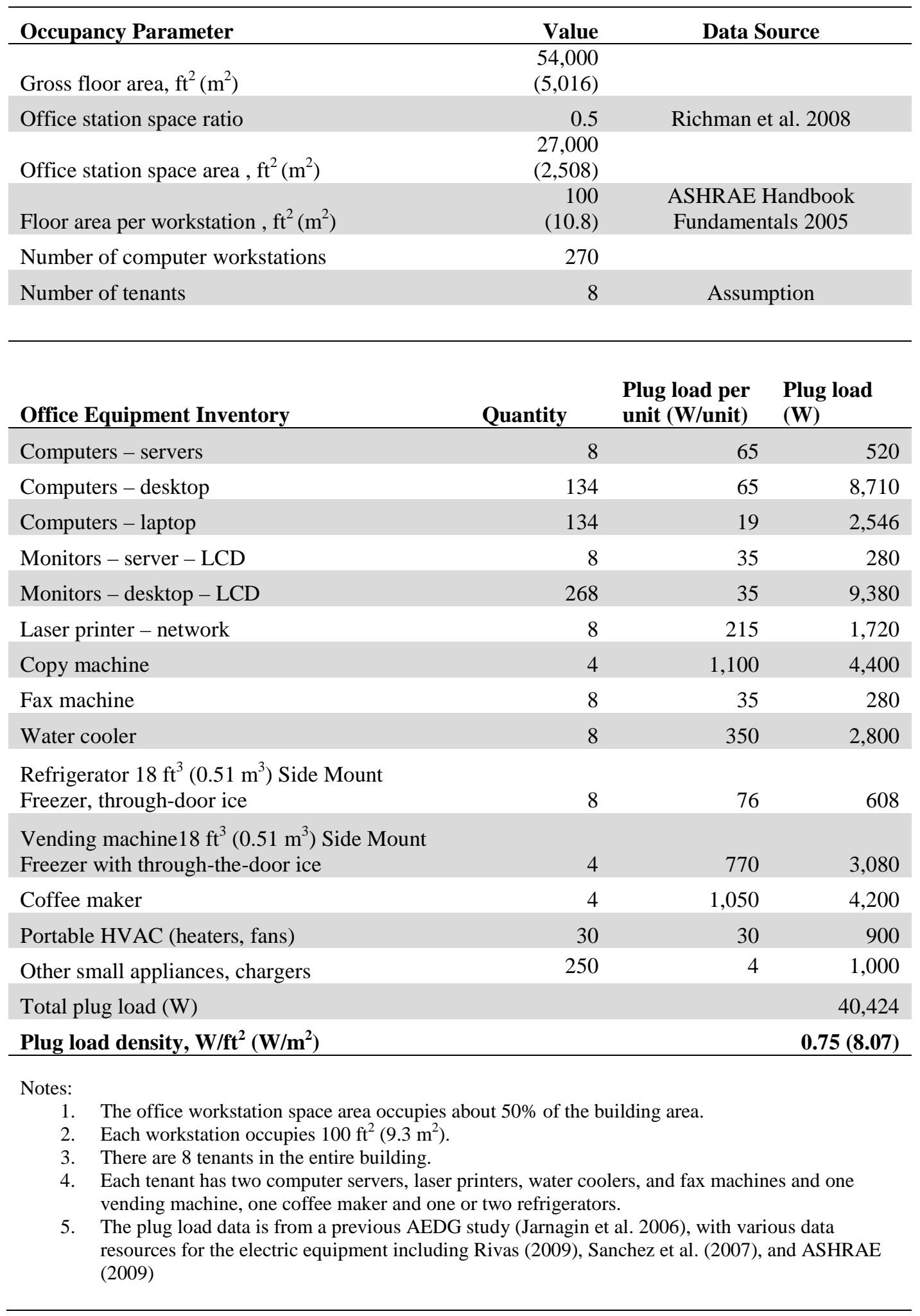




\subsubsection{HVAC Zoning}

The medium office building is also divided into five thermal zones on each of the three floors. The zones are established using a "four and core" approach with each orientation defining a perimeter zone that extends from the exterior wall inward for $15 \mathrm{ft}(4.6 \mathrm{~m})$. Each floor is served by an individual HVAC system. Figure 3.3 shows a zoning map of the medium office building.

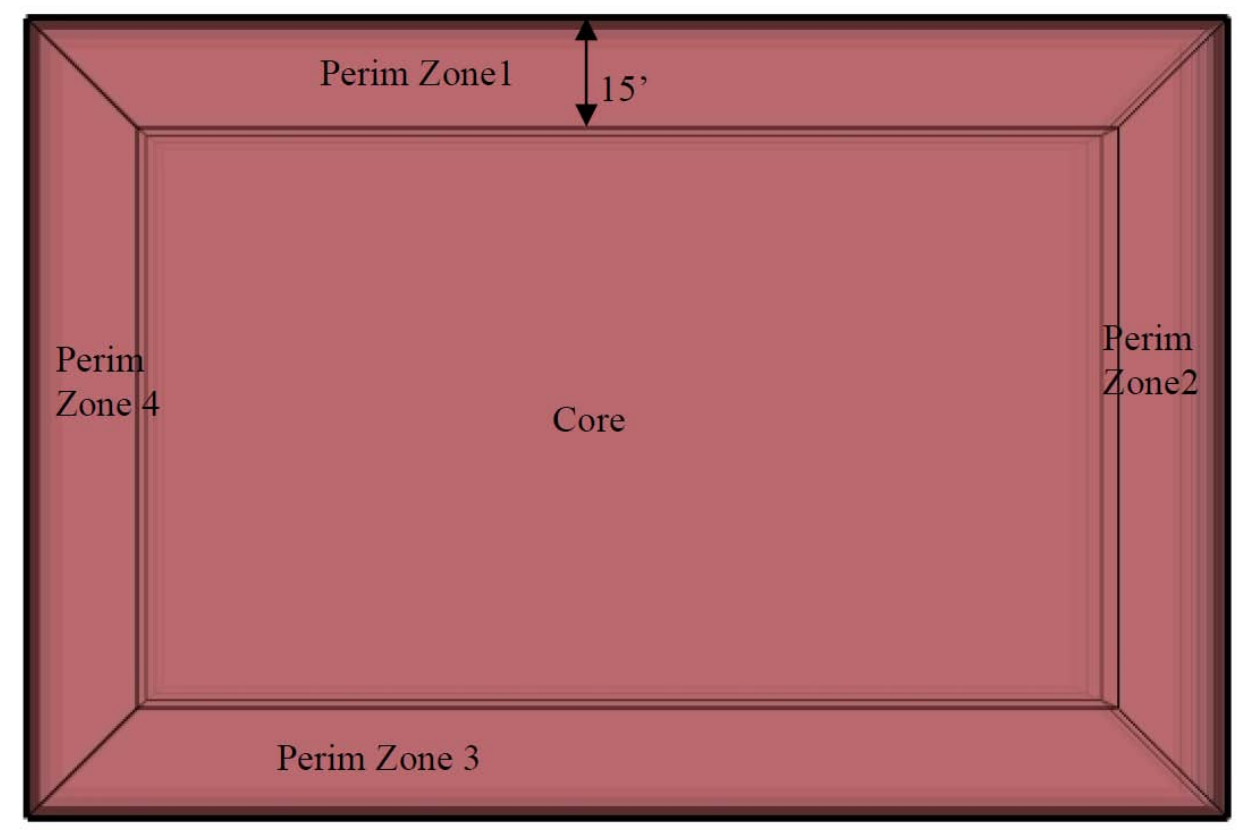

Figure 3.3. HVAC Zoning Map for the Medium Office Building

\subsubsection{Heating and Cooling Thermostat Setpoint}

The HVAC systems maintain a $70^{\circ} \mathrm{F}\left(21^{\circ} \mathrm{C}\right)$ heating setpoint and $75^{\circ} \mathrm{F}\left(24^{\circ} \mathrm{C}\right)$ cooling setpoint during occupied hours. During off hours, thermostat setback control strategy is also applied in the baseline prototypes, assuming a $5^{\circ} \mathrm{F}\left(2.8^{\circ} \mathrm{C}\right)$ temperature setback to $65^{\circ} \mathrm{F}\left(18.3^{\circ} \mathrm{C}\right)$ for heating and $5^{\circ} \mathrm{F}\left(2.8^{\circ} \mathrm{C}\right)$ temperature setup to $80^{\circ} \mathrm{F}\left(26.7^{\circ} \mathrm{C}\right)$ for cooling.

\subsubsection{HVAC Equipment Sizing}

HVAC equipment sizing refers to the method used to determine the capacity of the DX cooling coil, furnace and supply fan airflow in the packaged rooftop unit. EnergyPlus allows users to use a "design day" simulation method for sizing equipment. When using the design day simulation method, two separate design day inputs are specified, one for heating and one for cooling. The program determines the design peak loads by simulating the buildings for a 24-hour period on each of the design days. The design peak loads are then used by the subprogram for sizing HVAC equipment. This analysis uses the design day sizing method primarily for two reasons: 1 ) it is common practice for designers to choose the design day method for sizing the HVAC equipment; and 2) using the design day method will prevent equipment oversizing to meet the extreme peak weather conditions occurring for a very short period of time during a year. 
The design day data for all 16 climate locations were developed based on the "weather data" contained in the accompanying CD-ROM of ASHRAE 2005 Handbook of Fundamentals (ASHRAE 2005). In this data set, heating design day condition is based on the 99.6 annual percentile frequency of occurrence. The 99.6 annual percentile means that the dry-bulb temperature equals or is below the heating design condition for 35 hours per year in cold conditions. Similarly, annual cooling design condition is based on dry-bulb temperature corresponding to $1 \%$ annual cumulative frequency of occurrence in warm conditions. A $1 \%$ value of occurrence means that the dry-bulb temperature equals or exceeds the cooling design condition for 88 hours per year. Additionally, the range of the dry-bulb temperature for summer is in compliance with ASHRAE Standard 90.1-2004. In EnergyPlus simulations, design day schedules can also be specified. To be consistent with the general design practice for HVAC equipment sizing, the internal loads (occupancy, lights, and plug loads) were scheduled as zero on the heating design day, and as maximum level on the cooling design day.

\subsubsection{HVAC Equipment Efficiency}

Standard 90.1-2004 specifies HVAC equipment efficiency based on heating and cooling capacities. For single packaged equipment with cooling capacities less than 65,000 Btu/hr (19 kW), efficiency is rated by seasonal energy efficiency ratio (SEER), which represents an average efficiency throughout the year. SEER is defined as the total cooling output of an air conditioner during its normal annual usage period for cooling (in Btu) divided by the total electric energy during the same period (in Wh). Larger cooling equipment with cooling capacities greater than 65,000 Btu/hr $(19 \mathrm{~kW})$ is rated by energy efficiency ratio (EER), which represents efficiency at a particular design condition, and is defined as the ratio of net cooling capacity in Btu/hr to total rate of electric input in Watts at rated conditions.

When determining efficiency requirements, the Standard allows air conditioning units with a heating section other than electric resistance to take a credit of 0.2, which is subtracted from the required EER. In EnergyPlus, the efficiency of direct expansion cooling systems is indicated by entering a coefficient of performance (COP), which is defined as the cooling power output in watts divided by the electrical power input in watts determined at the same environmental conditions as the EER. However, unlike EER, the COP input in EnergyPlus does not include the rated power consumption of the supply air fan, so an adjustment to the EER is needed to remove the effect of the indoor fan energy. In addition, for equipment rated by SEER, a conversion from SEER is also required (Wassmer and Brandemuehl 2006). The COP input in EnergyPlus is determined by the following equations.

$$
\begin{gathered}
E E R=-0.0182 * S E E R^{2}+1.1088 * \text { SEER } \\
C O P=(E E R / 3.413+R) /(1-R)
\end{gathered}
$$

where $\mathrm{R}$ is the ratio of supply fan power to total equipment power at the rating condition.

Typical values of fan power ratio $\mathrm{R}$ for a commercial rooftop unit vary from about 0.05 to 0.17 depending on specific product design choices. For this analysis, we assume a ratio of about 0.12 as being representative of the broad class of products (PNNL 2004). Table 3.4 shows the cooling efficiency requirements for the HVAC equipment in the small and medium office buildings and the calculated COP for input in the EnergyPlus model. 
Table 3.4. Single Packaged Air Conditioner Baseline Efficiency

\begin{tabular}{lcc}
\hline \multicolumn{1}{c}{ Size Category } & $\begin{array}{c}\text { Minimum Efficiency } \\
\text { from ASHRAE } \\
\text { Standard 90.1- 2004 }\end{array}$ & $\begin{array}{c}\text { Efficiency as } \\
\text { input in } \\
\text { EnergyPlus }\end{array}$ \\
\hline$<65,000 \mathrm{Btu} / \mathrm{h}(<19 \mathrm{~kW})^{(\mathrm{a})}$ & 9.7 SEER & $3.15 \mathrm{COP}$ \\
$65,000 \sim 135,000 \mathrm{Btu} / \mathrm{h}(19 \sim 40 \mathrm{~kW})$ & $10.1 \mathrm{EER}$ & $3.50 \mathrm{COP}$ \\
$135,000 \sim 240,000 \mathrm{Btu} / \mathrm{h}(40 \sim 70 \mathrm{~kW})$ & $9.5 \mathrm{EER}$ & $3.30 \mathrm{COP}$ \\
$240,000 \sim 760,000 \mathrm{Btu} / \mathrm{h}(70 \sim 223 \mathrm{~kW})$ & $9.5 \mathrm{EER}$ & $3.30 \mathrm{COP}$ \\
$\geq 760,000 \mathrm{Btu} / \mathrm{h}(\geq 223 \mathrm{~kW})$ & $9.0 \mathrm{EER}$ & $3.13 \mathrm{COP}$ \\
\hline
\end{tabular}

(a) This size category is not applicable for the medium office prototype.

Gas Furnaces less than 225,000 Btu/hr (66 kW) are rated by average fuel utilization efficiency (AFUE), which, like SEER, represents average annual efficiency. The efficiency requirement for these units is $78 \%$ AFUE. Furnaces larger than 225,000 Btu/hr (66 kW) must meet an $80 \%$ combustion efficiency $\left(\mathrm{E}_{\mathrm{c}}\right)$.

\subsubsection{HVAC System Fan Power}

ASHRAE Standard 90.1- 2004 specifies maximum fan power allowances for fans with motors exceeding $5 \mathrm{hp}(3.73 \mathrm{~kW})$. Based on system sizing runs, all of the fan systems in the medium office prototype have motors in excess of $5 \mathrm{hp}(3.73 \mathrm{~kW})$. In Standard 90.1-2004, the maximum fan power allowance is expressed as a total fan system nameplate horsepower per supply fan airflow in cfm. Fan system power is based on the total of supply fans, return fans, and exhaust fans. Because the medium office building includes only supply fans, this requirement is in effect a maximum allowance for the supply fan motor. According to Standard 90.1-2004, the maximum allowance is $0.0017 \mathrm{hp} / \mathrm{cfm}$ ( 2.70 $\left.\mathrm{kW} / \mathrm{m}^{3} / \mathrm{s}\right)$ for systems with supply air volume less than $20,000 \mathrm{cfm}\left(9.44 \mathrm{~m}^{3} / \mathrm{s}\right)$ and $0.0015 \mathrm{hp} / \mathrm{cfm}(2.38$ $\mathrm{kW} / \mathrm{m}^{3} / \mathrm{s}$ ) for systems with supply air volume greater than $20,000 \mathrm{cfm}\left(9.44 \mathrm{~m}^{3} / \mathrm{s}\right)$. In the Medium Office prototype, there are supply fans both below and above the 20,000 cfm $\left(9.44 \mathrm{~m}^{3} / \mathrm{s}\right)$ threshold depending on served thermal zones and climate locations.

The EnergyPlus program simulates fan power by considering three inputs for a variable air volume fan: the design pressure drop through the fan, total fan efficiency, and the motor efficiency. The design pressure drop through the fan can be calculated using the following equation:

Design Pressure Drop = (brake horsepower x fan efficiency x 6356) $/ \mathrm{cfm}$

where,

$\mathrm{cfm} \quad=$ supply fan airflow as determined by EnergyPlus sizing runs

fan efficiency $\quad=65 \%$, based on assumptions used by the ASHRAE Standard 90.1 Committee while developing fan power requirements for the Standard.

brake horsepower $=$ brake horsepower is assumed to equal $90 \%$ of the maximum nameplate horsepower allowed for the supply cfm by Standard 90.1 . 
The result of above equation is that the design pressure drop for all systems less than 20,000 $\mathrm{cfm}$ $\left(9.44 \mathrm{~m}^{3} / \mathrm{s}\right)$ is input in the EnergyPlus model as 6.32 inch water column (1580 Pa) and 5.58 inch water column (1395 Pa) for systems greater than or equal to $20,000 \mathrm{cfm}\left(9.44 \mathrm{~m}^{3} / \mathrm{s}\right)$.

The last required input, motor efficiency, is taken directly from Table 10.8 of Standard 90.1- 2004, based on motor nameplate size, assuming enclosed motors operating at 1,800 rpm.

\subsubsection{Outdoor Air Ventilation Rates and Schedules}

Outdoor air ventilation requirements used in the base case are as required by ASHRAE Ventilation Standard 62.1-2004 (ANSI/ASHRAE 2004). Standard 62.1-2004 provides a methodology for calculating the ventilation requirements for offices with HVAC systems that include multiple zones. Initially, airflow is calculated based on $0.06 \mathrm{cfm} / \mathrm{ft}^{2}\left(3.05 \mathrm{E}-4 \mathrm{~m} / \mathrm{s} / \mathrm{m}^{2}\right)$ of floor area plus $5 \mathrm{cfm}$ per person (2.36E-3 $\mathrm{m}^{3} / \mathrm{s} /$ person). Assuming typical office occupancy rates of 5 people per 1,000 square feet (gross), the ventilation rate for the baseline medium office building is $0.085 \mathrm{cfm} / \mathrm{ft}^{2}\left(4.32 \mathrm{E}-4 \mathrm{~m} / \mathrm{s} / \mathrm{m}^{2}\right)$ of gross area. This is adjusted for critical zones and ventilation effectiveness resulting in a ventilation rate of $0.1115 \mathrm{cfm} / \mathrm{ft}^{2}\left(5.66 \mathrm{E}-3 \mathrm{~m}^{3} / \mathrm{s} / \mathrm{m}^{2}\right)$.

For the medium office building in climate zones 4, 5, 6, 7, and 8, Standard 90.1-2004 requires outdoor air systems equipped with motorized dampers that automatically close when the systems served are not in use or when they run to meet night setback or provide morning warm-up. Therefore, in those climate zones, hourly ventilation air schedules were developed in our medium office prototype to simulate a two-step control strategy: 1) during the occupied hours, maintain the outdoor air damper at the minimum intake position, or modulate $100 \%$ open if the system operates in the economizer mode;

2) during unoccupied hours, automatically close the outdoor air damper to reduce unnecessary outside air intake into the building. In climate zones 1, 2, and 3, where gravity dampers are allowed by Standard 90.1-2004, the dampers are simulated as being open to minimum position whenever the HVAC system is running, even when the building is unoccupied.

\subsubsection{Economizer Use}

The baseline HVAC systems are simulated with economizers when required by Standard 90.1- 2004. The Standard does not require economizers if the system cooling capacity is less than 65,000 Btu/hr $(19 \mathrm{~kW})$ regardless of climate zone. For cooling capacities greater than 65,000 Btu/hr (19 kW), economizers are required depending on the climate zone and the capacity, as indicated in Table 3.5. The baseline building simulation assumes that the economizer high limit shutoff will be controlled by differential dry-bulb temperature, a control option allowed by the Standard in each of the climate zones simulated. Under this control scenario, when the outdoor air temperature is below both the return air temperature and the high ambient shutoff temperature, the economizer is enabled. 
Table 3.5. Economizer Requirements in the Standard 90.1-2004

\begin{tabular}{llcc}
\hline Climate & Ropresentative City & $\begin{array}{c}\text { Economizer Required } \\
\text { if Cooling Capacity } \\
\geq 65,000 \mathrm{Btu} / \mathrm{h}(19 \\
\mathrm{kW}) \text { and }<135,000 \\
\text { Btu/h }(40 \mathrm{~kW})\end{array}$ & $\begin{array}{c}\text { Economizer } \\
\text { Required if Cooling } \\
\text { Capacity } \geq 135,000 \\
\text { Btu/h }(40 \mathrm{~kW})\end{array}$ \\
\hline 1A & Miami & No & No \\
\hline 2A & Houston & No & No \\
\hline 2B & Phoenix & No & Yes \\
\hline 3A & Atlanta & No & No \\
\hline 3B-CA & Los Angeles & Yes & Yes \\
\hline 3B-other & Las Vegas & Yes & Yes \\
\hline 3C & San Francisco & Yes & Yes \\
\hline 4A & Baltimore & No & No \\
\hline 4B & Albuquerque & Yes & Yes \\
\hline 4C & Seattle & Yes & Yes \\
\hline 5A & Chicago & No & Yes \\
\hline 5B & Denver & Yes & Yes \\
\hline 6A & Minneapolis & No & Yes \\
\hline 6B & Helena & Yes & Yes \\
\hline 7 & Duluth & No & Yes \\
\hline 8 & Fairbanks & No & Yes \\
\hline & & & \\
\hline
\end{tabular}

\subsection{Service Hot Water System}

The baseline service hot water system for the medium office building is defined as a gas-fired storage water heater with a hot water recirculation loop. The equipment meets the minimum equipment efficiency requirements under Standard 90.1-2004. The hot water supply temperature is assumed to be $120^{\circ} \mathrm{F}\left(48.9^{\circ} \mathrm{C}\right)$.

To estimate the energy performance of a service water heater with a storage tank, the EnergyPlus program requires the user to define the following key input variables as the operating parameters:

- the rated storage tank volume

- peak hot water flow rate

- hot water use schedule

- the maximum heater capacity - the heating capacity of the burner used to meet the domestic hot water load and charge the tank

- the standby heat loss coefficient (UA) 
- the heater thermal efficiency $\left(E_{t}\right)$ - this is a ratio of heating capacity at full load to gas heat input.

\subsubsection{Hot Water Usage}

The typical hot water use for office buildings is 1 gallon (3.8 L) per person per day, as shown in Table 7 of Chapter 49 Service Water Heating in ASHRAE Applications Handbook (ASHRAE 2007). This results in a daily hot water consumption of 268 gallons $\left(1.01 \mathrm{~m}^{3}\right)$ for the medium office building. From the amount and the profile of daily hot water consumption, the peak hot water flow rate was calculated as $0.832 \mathrm{gpm}(0.005 \mathrm{~L} / \mathrm{s})$.

\subsubsection{Storage Tank Size}

The water heater storage tank volume was sized based on the methodology described in the 2007 ASHRAE Applications Handbook (ASHRAE 2007). According to Table 7 of Chapter 49, the maximum hourly hot water demand is about 0.4 gallons $(1.5 \mathrm{~L})$ per person. This leads to a peak demand of 107 gallon $\left(0.41 \mathrm{~m}^{3}\right)$ for the modeled prototype office building. Assuming $70 \%$ of the hot water in a storage tank is usable (ASHRAE 2007), the storage tank capacity is sized as 153 gallons $\left(0.58 \mathrm{~m}^{3}\right)$. Thus, the simulation includes two tanks of 100 gallons (380 L) each.

\subsubsection{Rated Input Power and Standby Heat Loss Coefficient}

For commercial gas storage water heaters, the minimum performance required is expressed as two values, thermal efficiency $\left(\mathrm{E}_{\mathrm{t}}\right)$ and the standby loss (SL). A typical input rating for a 100 gallon $(380 \mathrm{~L})$ water heater is $199,000 \mathrm{Btu} / \mathrm{hr}(58 \mathrm{~kW})$. For a water heater with rated input larger than 75,000 Btu/hr ( $22 \mathrm{~kW}$ ), the minimum $\mathrm{E}_{\mathrm{t}}$ required is $80 \%$. The maximum standby loss SL is $1348.8 \mathrm{Btu} / \mathrm{hr}$ (395 W) using following equation required in the Standard:

$$
S L=\frac{Q}{800}+110 \sqrt{V}
$$

where $S L=$ standby heat loss $(\mathrm{Btu} / \mathrm{hr})$

$Q=$ rated input power $(\mathrm{Btu} / \mathrm{hr})$

$V=$ rated storage tank volume (gallons)

Based on commercial water heater manufacturer's equipment specifications, the most common input rating of a 100 gallon (380 L) gas water heater with an input rating of 199,000 Btu/hr (58 kW), is a recovery efficiency of $80 \%$. Furthermore, the standby heat loss coefficient (UA) of the commercial heater was determined using the following equation:

$$
U A=\frac{S L \times R E}{70}
$$

where $U A=$ standby heat loss efficient $\left(\mathrm{Btu} / \mathrm{hr} \cdot{ }^{\circ} \mathrm{F}\right)$

$S L=$ standby heat loss $(\mathrm{Btu} / \mathrm{hr})$

$R E=$ recovery efficiency 
$70=$ difference in temperature between stored water thermostat set point and ambient air temperature at the test condition $\left({ }^{\circ} \mathrm{F}\right)$

Inserting the appropriate values for SL and RE, results in a UA of $15.414 \mathrm{Btu} / \mathrm{hr}-{ }^{\circ} \mathrm{F}(8.13 \mathrm{~W} / \mathrm{K})$, as one of input variables for the office prototype in the EnergyPlus program.

\subsubsection{Water Heater Thermal Efficiency}

The water heater thermal efficiency $E_{t}$ was set as 0.80 to match the minimum performance requirement under the Standard for gas storage water heater with rated input $\geq 75,000 \mathrm{Btu} / \mathrm{hr}(22 \mathrm{~kW})$. 


\subsection{Development of Advanced Building Model and Assumptions}

The advanced building models are developed by adding a number of energy efficiency measures (EEMs) to the baseline building models. The EEM concepts were developed based on a number of resources including the advanced building design guides (Hydeman et al. 2005, Jarnagin et al. 2006), the approved and proposed addenda to ASHRAE Standard 90.1-2007, a High-Performance Building Database (NBI 2008), the authors' professional experiences, and inputs from industry experts. The following two factors were given full considerations in developing EEMs. First, the EEMs should be based on technologies that are commercially available from multiple sources. Second, the EEMs can be modeled directly or via a work-around approach by the current version (v3.0) of the EnergyPlus simulation program. All proposed EEMs can be grouped into the following five categories:

- Building envelope measures such as enhanced building opaque envelope insulation and highperformance fenestration.

- Lighting measures that reduce connected lighting load and advanced automatic lighting controls such as daylight harvesting and occupancy based controls.

- HVAC measures such as dedicated outdoor air systems, hydronic radiant heating and cooling systems, energy recovery ventilation, high efficiency equipment, and advanced controls.

- Service water heating measures such as higher efficiency equipment.

- Plug load measures such as using ENERGY STAR labeled office equipment and additional power management and controls.

This section describes the EEMs that were implemented in the advanced models and have demonstrated energy savings through EnergyPlus simulations.

\subsection{Envelope}

The advanced building models incorporate various energy efficiency measures while maintaining the same building form, orientation, window-to-wall ratios on each façade, and wall and roof construction types as those used in the baseline cases. In comparison with the baseline, the advanced models incorporate the following building envelope related energy efficiency measures.

\subsubsection{Enhanced Insulation for Opaque Assemblies}

The advanced insulation requirements for walls and roof are based on the public review draft of Addendum bb to ASHRAE Standard 90.1-2007. Exterior walls are the same steel-framed wall construction type as those in the baseline (see Section 3.3.1) but more continuous rigid board insulation is added to improve the overall thermal performance. Table 4.1 shows the wall assembly U-factors and the corresponding insulation R-values for both baseline and advanced models. Similarly, roofs have insulation entirely above metal deck construction type (see Section 3.3.2) with enhanced insulation. Table 4.2 shows the roof assembly U-factors and the corresponding rigid insulation R-values. 
The enhanced insulation requirements are achieved by changing the insulation layers' thermal resistance. Because only thermal resistance is modeled for the insulation layers in this work, the thermal mass of the opaque assemblies does not change between the baseline and the advanced models.

Table 4.1. Insulation Requirements for Above Grade Steel-Framed Walls

\begin{tabular}{|c|c|c|c|c|}
\hline \multirow[b]{2}{*}{ Climate Zone } & \multicolumn{2}{|r|}{ Baseline } & \multicolumn{2}{|c|}{ Advanced Model } \\
\hline & $\begin{array}{c}\text { Assembly U- } \\
\text { factor } \\
\mathrm{Btu} / \mathrm{h} \cdot \mathrm{ft}^{2} \cdot \mathrm{F} \\
\left(\mathrm{W} / \mathrm{m}^{2} / \mathrm{K}\right) \\
\end{array}$ & $\begin{array}{l}\text { Rated insulation R-value } \\
\mathrm{ft}^{2} \cdot \mathrm{F} \cdot \mathrm{h} / \mathrm{Btu}\left(\mathrm{K} \cdot \mathrm{m}^{2} / \mathrm{W}\right)\end{array}$ & $\begin{array}{l}\text { Assembly U- } \\
\text { factor } \\
\text { Btu/h.ft' } \mathrm{ft}^{2} \cdot \mathrm{F} \\
\left(\mathrm{W} / \mathrm{m}^{2} / \mathrm{K}\right) \\
\end{array}$ & $\begin{array}{l}\text { Rated insulation R-value } \\
\mathrm{ft}^{2} \cdot \mathrm{F} \cdot \mathrm{h} / \mathrm{Btu}\left(\mathrm{K} \cdot \mathrm{m}^{2} / \mathrm{W}\right)\end{array}$ \\
\hline 1 & $0.124(0.705)$ & $\begin{array}{l}\mathrm{R}-13.0 \\
(\mathrm{R}-2.3)\end{array}$ & $\begin{array}{c}0.064 \\
(0.365)\end{array}$ & $\begin{array}{l}\text { R-13.0 + R-7.5 c.i. } \\
\text { (R-2.3 + R-1.3 c.i.) }\end{array}$ \\
\hline 2 & $0.124(0.705)$ & $\begin{array}{l}\mathrm{R}-13.0 \\
(\mathrm{R}-2.3)\end{array}$ & $\begin{array}{c}0.064 \\
(0.365)\end{array}$ & $\begin{array}{l}\text { R-13.0 + R-7.5 c.i. } \\
\text { (R-2.3 + R-1.3 c.i.) }\end{array}$ \\
\hline 3 & $0.124(0.705)$ & $\begin{array}{l}\mathrm{R}-13.0 \\
(\mathrm{R}-2.3)\end{array}$ & $\begin{array}{c}0.064 \\
(0.365)\end{array}$ & $\begin{array}{l}\text { R-13.0 + R-7.5 c.i. } \\
\text { (R-2.3 + R-1.3 c.i.) }\end{array}$ \\
\hline 4 & $0.124(0.705)$ & $\begin{array}{l}\mathrm{R}-13.0 \\
\text { (R-2.3) }\end{array}$ & $\begin{array}{c}0.064 \\
(0.365)\end{array}$ & $\begin{array}{l}\text { R-13.0 + R-7.5 c.i. } \\
\text { (R-2.3 + R-1.3 c.i.) }\end{array}$ \\
\hline 5 & $0.084(0.479)$ & $\begin{array}{l}\text { R-13.0 + R-3.8 c.i. } \\
\text { (R-2.3 + R-0.7 c.i.) }\end{array}$ & $\begin{array}{c}0.042 \\
(0.240)\end{array}$ & $\begin{array}{l}\text { R-13.0 + R-15.6 c.i. } \\
\text { (R-2.3 + R-2.7 c.i.) }\end{array}$ \\
\hline 6 & $0.084(0.479)$ & $\begin{array}{l}\text { R-13.0 + R-3.8 c.i. } \\
\text { (R-2.3 + R-0.7 c.i.) }\end{array}$ & $\begin{array}{c}0.037 \\
(0.212)\end{array}$ & $\begin{array}{l}\text { R-13.0 + R-18.8 c.i. } \\
\text { (R-2.3 + R-3.3 c.i.) }\end{array}$ \\
\hline 7 & $0.064(0.365)$ & $\begin{array}{l}\text { R-13.0 + R-7.5 c.i. } \\
\text { (R-2.3 + R-1.3 c.i.) }\end{array}$ & $\begin{array}{c}0.037 \\
(0.212)\end{array}$ & $\begin{array}{l}\text { R-13.0 + R-18.8 c.i. } \\
\text { (R-2.3 + R-3.3 c.i.) }\end{array}$ \\
\hline 8 & $0.064(0.365)$ & $\begin{array}{l}\text { R-13.0 + R-7.5 c.i. } \\
\text { (R-2.3 + R-1.3 c.i.) }\end{array}$ & $\begin{array}{r}0.037 \\
(0.212) \\
\end{array}$ & $\begin{array}{l}\text { R-13.0 + R-18.8 c.i. } \\
\text { (R-2.3 + R-3.3 c.i.) }\end{array}$ \\
\hline
\end{tabular}


Table 4.2. Insulation Requirements for the Roof with Continuous Insulation Above Deck

\begin{tabular}{|c|c|c|c|c|}
\hline \multirow[b]{2}{*}{ Climate Zone } & \multicolumn{2}{|r|}{ Baseline } & \multicolumn{2}{|c|}{ Advanced Model } \\
\hline & $\begin{array}{l}\text { Assembly U- } \\
\text { factor } \\
\text { Btu/h.ft' }{ }^{2} \cdot \mathrm{F} \\
\left(\mathrm{W} / \mathrm{m}^{2} / \mathrm{K}\right)\end{array}$ & $\begin{array}{c}\text { Rated insulation R-value } \\
\mathrm{ft}^{2} \cdot \mathrm{F} \cdot \mathrm{h} / \mathrm{Btu}\left(\mathrm{K} \cdot \mathrm{m}^{2} / \mathrm{W}\right)\end{array}$ & $\begin{array}{c}\text { Assembly U- } \\
\text { factor } \\
\mathrm{Btu} / \mathrm{h} \cdot \mathrm{ft}^{2} \cdot \mathrm{F} \\
\left(\mathrm{W} / \mathrm{m}^{2} / \mathrm{K}\right)\end{array}$ & $\begin{array}{c}\text { Rated insulation R-value } \\
\mathrm{ft}^{2} \cdot \mathrm{F} \cdot \mathrm{h} / \mathrm{Btu}\left(\mathrm{K} \cdot \mathrm{m}^{2} / \mathrm{W}\right)\end{array}$ \\
\hline 1 & $0.063(0.360)$ & $\begin{array}{c}\text { R-15 c.i. } \\
\text { (R-2.6 c.i.) }\end{array}$ & $0.048(0.273)$ & $\begin{array}{c}\text { R-20 c.i. } \\
\text { (R-3.5 c.i.) }\end{array}$ \\
\hline 2 & $0.063(0.358)$ & $\begin{array}{l}\text { R-15 c.i. } \\
\text { (R-2.6 c.i.) }\end{array}$ & $0.039(0.220)$ & $\begin{array}{l}\text { R-25 c.i. } \\
\text { (R-4.4 c.i.) }\end{array}$ \\
\hline 3 & $0.063(0.358)$ & $\begin{array}{l}\text { R-15 c.i. } \\
\text { (R-2.6 c.i.) }\end{array}$ & $0.039(0.220)$ & $\begin{array}{l}\text { R-25 c.i. } \\
\text { (R-4.4 c.i.) }\end{array}$ \\
\hline 4 & $0.063(0.358)$ & $\begin{array}{l}\text { R-15 c.i. } \\
\text { (R-2.6 c.i.) }\end{array}$ & $0.032(0.184)$ & $\begin{array}{l}\text { R-30 c.i. } \\
\text { (R-5.3 c.i.) }\end{array}$ \\
\hline 5 & $0.063(0.358)$ & $\begin{array}{l}\text { R-15 c.i. } \\
\text { (R-2.6 c.i.) }\end{array}$ & $0.032(0.184)$ & $\begin{array}{l}\text { R-30 c.i. } \\
\text { (R-5.3 c.i.) }\end{array}$ \\
\hline 6 & $0.063(0.358)$ & $\begin{array}{l}\text { R-15 c.i. } \\
\text { (R-2.6 c.i.) }\end{array}$ & $0.032(0.184)$ & $\begin{array}{l}\text { R-30 c.i. } \\
\text { (R-5.3 c.i.) }\end{array}$ \\
\hline 7 & $0.063(0.358)$ & $\begin{array}{l}\text { R-15 c.i. } \\
\text { (R-2.6 c.i.) }\end{array}$ & $0.028(0.159)$ & $\begin{array}{l}\text { R-35 c.i. } \\
\text { (R-6.2 c.i.) }\end{array}$ \\
\hline 8 & $0.048(0.273)$ & $\begin{array}{l}\text { R-20 c.i. } \\
\text { (R-3.5 c.i.) }\end{array}$ & $0.028(0.159)$ & $\begin{array}{l}\text { R-35 c.i. } \\
\text { (R-6.2 c.i.) }\end{array}$ \\
\hline
\end{tabular}

\subsubsection{Cool Roof}

Considering that cooling is one of the major end uses for office buildings, a cool roof that reflects solar energy can be an effective energy-efficiency measure in hot climates (Jarnagin et al. 2006, Konopacki and Akbari 2001). Therefore, in the advanced models, the exterior layer of the built-up roof system is modeled as a light colored, reflective roofing membrane (such as white EDPM), which has solar reflectance of 0.69 and thermal emittance of 0.87 (LBNL 2009). In contrast, the exterior roof layer in the baseline models is a kind of gray EPDM with solar reflectance of 0.23 and thermal emittance of 0.87 . Following the Advanced Energy Design Guide series (Jarnagin et al. 2006, Liu et al 2007, Jiang et al. 2008), cool roof is used only in climate zones 1 through 3.

\subsubsection{High Performance Windows}

The advanced models maintain the same window area as the baseline model, but change the window construction to have improved performance in terms of the U-value and the SHGC value. The targeted U and SHGC values are from the public review draft of Addendum bb to 90.1-2007. As noted under the baseline, the analysis is based on the understanding that typical medium office fenestration uses curtain wall or storefront framing systems.

Addendum bb provides values for fixed metal-framed windows distinct from curtain wall or storefront windows other than curtain wall or storefront. In addendum bb, these fixed frame values are less stringent than the U-values for curtain wall and storefront. However, generally curtain wall and storefront systems are not able to achieve as low a U-value as fixed frame windows because of the available framing system conductance. In reviewing the performance values identified in the ASHRAE 
Fundamentals 2009 (Chapter 15, Table 4) and industry experience, the fixed frame U-factors in Addendum bb are chosen as appropriate for high performance curtain wall systems (Table 4.3). There are newer curtain wall framing systems available from a few vendors that can achieve very low frame conductance and correspondingly lower overall window U-factors, but these systems have very limited distribution and high cost. In Table 4.3, the baseline U and SHGC values are presented along with the advanced values to facilitate comparison. The baseline values from ASHRAE 90.1-2004 are for all window types, not distinguished by framing type. The U-factor values are overall values for a window assembly including framing elements.

One potential energy efficiency measure not addressed in this document is to reduce the window area. The window-to-wall ratio defined in the baseline is 33\% for each facade. Significant energy savings could result from reducing the window-to-wall ratio, in particular for the east and west orientations. This measure was not included in the recommendations because it might trigger significant resistance from architects and developers who believe that a building with larger window areas is more commercially attractive. It may take enforced code changes to make real progress in this area (reduced window-to-wall area maximums are being considered and implemented in development of the 90.1 Standard).

Table 4.3. Fenestration U-factor and SHGC values

\begin{tabular}{|c|c|c|c|c|c|c|c|c|}
\hline \multirow[b]{3}{*}{$\begin{array}{l}\text { Climate } \\
\text { Zone }\end{array}$} & \multicolumn{4}{|c|}{ Baseline } & \multicolumn{4}{|c|}{ Advanced Model } \\
\hline & \multicolumn{2}{|c|}{ Target values } & \multicolumn{2}{|c|}{ Modeled values } & \multicolumn{2}{|c|}{ Target values } & \multicolumn{2}{|c|}{ Modeled values } \\
\hline & $\begin{array}{l}\text { U-factor } \\
\mathrm{Btu} / \mathrm{h} \cdot \mathrm{ft}^{2} \cdot \mathrm{F} \\
\left(\mathrm{W} / \mathrm{m}^{2} \cdot \mathrm{K}\right)\end{array}$ & SHGC & $\begin{array}{l}\text { U-factor } \\
\mathrm{Btu} / \mathrm{h} \cdot \mathrm{ft}^{2} \cdot \mathrm{F} \\
\left(\mathrm{W} / \mathrm{m}^{2} \cdot \mathrm{K}\right)\end{array}$ & SHGC & $\begin{array}{l}\text { U-factor } \\
\text { Btu/h. } \mathrm{ft}^{2} \cdot \mathrm{F} \\
\left(\mathrm{W} / \mathrm{m}^{2} \cdot \mathrm{K}\right)\end{array}$ & SHGC & $\begin{array}{l}\text { U-factor } \\
\mathrm{Btu} / \mathrm{h} \cdot \mathrm{ft}^{2} \cdot \mathrm{F} \\
\left(\mathrm{W} / \mathrm{m}^{2} \cdot \mathrm{K}\right)\end{array}$ & SHGC \\
\hline 1 & $\begin{array}{c}1.22 \\
(6.92)\end{array}$ & 0.25 & $\begin{array}{c}1.08 \\
(6.13)\end{array}$ & 0.28 & $\begin{array}{c}0.65 \\
(3.69)\end{array}$ & 0.25 & $\begin{array}{c}0.51 \\
(2.89)\end{array}$ & 0.28 \\
\hline 2 & $\begin{array}{c}1.22 \\
(6.92)\end{array}$ & 0.25 & $\begin{array}{c}1.08 \\
(6.13)\end{array}$ & 0.28 & $\begin{array}{c}0.65 \\
(3.69)\end{array}$ & 0.25 & $\begin{array}{c}0.51 \\
(2.89)\end{array}$ & 0.28 \\
\hline $3 \mathrm{~A}, 3 \mathrm{~B}$ & $\begin{array}{c}0.57 \\
(3.23)\end{array}$ & 0.25 & $\begin{array}{c}0.51 \\
(2.89)\end{array}$ & 0.28 & $\begin{array}{c}0.6 \\
(3.41)\end{array}$ & 0.25 & $\begin{array}{c}0.51 \\
(2.89)\end{array}$ & 0.28 \\
\hline $3 C$ & $\begin{array}{c}1.22 \\
(6.92)\end{array}$ & 0.34 & $\begin{array}{c}0.94 \\
(5.33)\end{array}$ & 0.34 & $\begin{array}{c}0.6 \\
(3.41)\end{array}$ & 0.25 & $\begin{array}{c}0.51 \\
(2.89)\end{array}$ & 0.28 \\
\hline 4 & $\begin{array}{c}0.57 \\
(3.23)\end{array}$ & 0.39 & $\begin{array}{c}0.55 \\
(3.12)\end{array}$ & 0.43 & $\begin{array}{c}0.44 \\
(2.50)\end{array}$ & 0.26 & $\begin{array}{c}0.44 \\
(2.50)\end{array}$ & 0.24 \\
\hline 5 & $\begin{array}{c}0.57 \\
(3.23)\end{array}$ & 0.39 & $\begin{array}{c}0.55 \\
(3.12)\end{array}$ & 0.43 & $\begin{array}{c}0.44 \\
(2.50)\end{array}$ & 0.26 & $\begin{array}{c}0.44 \\
(2.50)\end{array}$ & 0.24 \\
\hline 6 & $\begin{array}{c}0.57 \\
(3.23)\end{array}$ & 0.39 & $\begin{array}{c}0.55 \\
(3.12)\end{array}$ & 0.43 & $\begin{array}{c}0.42 \\
(2.38)\end{array}$ & 0.35 & $\begin{array}{c}0.42 \\
(2.38)\end{array}$ & 0.39 \\
\hline 7 & $\begin{array}{c}0.57 \\
(3.23)\end{array}$ & 0.49 & $\begin{array}{c}0.55 \\
(3.12)\end{array}$ & 0.5 & $\begin{array}{c}0.34 \\
(1.93)\end{array}$ & 0.4 & $\begin{array}{c}0.31 \\
(1.76)\end{array}$ & 0.38 \\
\hline 8 & $\begin{array}{c}0.46 \\
(2.61)\end{array}$ & NR & $\begin{array}{c}0.48 \\
(2.72)\end{array}$ & 0.47 & $\begin{array}{c}0.34 \\
(1.93)\end{array}$ & 0.4 & $\begin{array}{c}0.31 \\
(1.76)\end{array}$ & 0.38 \\
\hline
\end{tabular}

As described in Chapter 3, in the current version of EnergyPlus, a window's performance including the U and SHGC values are derived from the glazing layers' solar-optical properties. It is a challenge to 
manually find a hypothetical window construction that matches given U and SHGC values exactly. To address the above challenge, a simplified strategy was used to find the closest match of a window construction in the EnergyPlus window library for given U and SHGC values. In the matching process, a close match to the SHGC value is regarded as a more important criterion for climate zones 1-3, where cooling load is a major consideration. On the other hand, a close match to the U-value is a more important criterion for climate zones 4 through 8, where heating load is the major consideration. Because only a close match can be found, there is a minor deviation between the modeled U and SHGC values and the target values. Table 4.3 also lists the actual performance for the selected window constructions in both baseline and advanced cases. The effects of window frame and dividers are not modeled explicitly.

\subsubsection{Permanent Shading Devices}

Window overhangs are employed in the advanced cases. Overhangs are normally an effective passive solar design strategy for south-oriented facades in the Northern Hemisphere because they limit solar gain during the warmer months when the sun is high while allowing solar gain during the heating season when the sun angle is lower. Overhangs are used only on the south façade for climate zones 1 through 5 . The overhang was modeled to have a projection factor of 0.5 and the distance between the overhang and the top of window is $0.66 \mathrm{ft}(0.2 \mathrm{~m})$. For this medium office building prototype, the windows have a height of $4.3 \mathrm{ft}(1.31 \mathrm{~m})$. Hence, the overhang projects outward from the wall about $(0.66+4.3) * 0.5=2.48 \mathrm{ft}$ $(0.75 \mathrm{~m})$.

Vertical fins are effective measures to block low-altitude sunlight for east- and west-oriented facades. However, they are not employed in the design package. This is mainly because the windows are assumed to be continuous ribbons along each orientation. With this assumption, the benefits from vertical fins are limited.

\subsection{Lighting}

Energy efficient measures are used in the advanced cases to reduce both interior and exterior lighting energy consumption. The implemented EEMs that address interior lighting include reduced interior lighting power density, occupancy sensor control, and daylighting with dimming control. The EEMs that address exterior lighting include reduced exterior lighting power allowances and exterior lighting control.

\subsubsection{Interior Lighting}

\subsubsection{Reduced Interior Lighting Power Density}

Lighting power density (LPD) can be reduced via the use of energy-efficient lighting systems and the suitable integration and layout of ambient lighting and task lighting. In this work, the space-by-space method is followed to determine the interior lighting power allowance. The LPD for the whole building is derived from the percentage of each space type and the designed LPD for each space. For the advanced case, different lighting systems may be used for a given space type. In this case, the designed LPD for each lighting system is also estimated. All the information for LPD calculation is presented in Table 4.4, where the baseline LPD calculation is also provided for comparison. Table 4.4 shows that the LPD can be reduced from $1.0 \mathrm{~W} / \mathrm{ft}^{2}\left(10.76 \mathrm{~W} / \mathrm{m}^{2}\right)$ in the baseline to $0.75 \mathrm{~W} / \mathrm{ft}^{2}\left(8.07 \mathrm{~W} / \mathrm{m}^{2}\right)$ in the advanced case. 
Table 4.4. Lighting Power Density Calculation for the Advanced Case

\begin{tabular}{|c|c|c|c|c|c|c|c|}
\hline \multirow[b]{2}{*}{ Space Type } & \multirow[b]{2}{*}{$\begin{array}{l}\text { Percentage } \\
\text { of Floor } \\
\text { Area }^{(a)}\end{array}$} & \multirow[b]{2}{*}{$\begin{array}{l}\text { Baseline } \\
\text { LPD } \\
\left(\mathrm{W} / \mathrm{ft}^{2}\right)\end{array}$} & \multirow[b]{2}{*}{$\begin{array}{l}\text { Baseline } \\
\qquad P D \\
\left(W / m^{2}\right)\end{array}$} & \multicolumn{4}{|c|}{ Advanced Model } \\
\hline & & & & Lighting Systems & $\begin{array}{l}\text { LPD Per } \\
\text { Lighting } \\
\text { System } \\
\left(\mathrm{W} / \mathrm{ft}^{2}\right)\end{array}$ & $\begin{array}{c}\mathrm{LPD} \\
\left(\mathrm{W} / \mathrm{ft}^{2}\right)\end{array}$ & $\begin{array}{c}L P D \\
\left(W / m^{2}\right)\end{array}$ \\
\hline \multirow[t]{4}{*}{ Office - open plan } & $16 \%$ & 1.1 & 11.8 & Task Lighting & 0.10 & 0.68 & 7.3 \\
\hline & & & & HP lensed & 0.33 & & \\
\hline & & & & $\begin{array}{l}\text { HP lensed daylight } \\
\text { zone }\end{array}$ & 0.20 & & \\
\hline & & & & Downlight & 0.05 & & \\
\hline Office - private & $25 \%$ & 1.1 & 11.8 & HP lensed & 0.80 & 0.80 & 8.6 \\
\hline \multirow[t]{3}{*}{ Conference meeting } & $10 \%$ & 1.3 & 14.0 & $\begin{array}{l}\text { Ambient } \\
\text { direct/indirect }\end{array}$ & 0.52 & 0.77 & 8.3 \\
\hline & & & & CFL Downlights & 0.47 & & \\
\hline & & & & Linear wall washing & 0.25 & & \\
\hline Corridor/Transition & $10 \%$ & 0.5 & 5.4 & $\begin{array}{l}90.1-2004 \text { design } \\
\text { with HP lamps and } \\
\text { ballasts }\end{array}$ & 0.50 & 0.50 & 5.4 \\
\hline Active storage & $15 \%$ & 0.8 & 8.6 & $\begin{array}{l}90.1-2004 \text { design } \\
\text { with HP lamps and } \\
\text { ballasts }\end{array}$ & 0.64 & 0.64 & 6.9 \\
\hline Restrooms & $4 \%$ & 0.8 & 8.6 & 90.1-2004 design & 0.82 & 0.82 & 8.8 \\
\hline Lounge/Recreation & $3 \%$ & 1.2 & 12.9 & HP lensed & 0.73 & 0.73 & 7.9 \\
\hline Electrical/Mechanical & $3 \%$ & 1.5 & 16.1 & $\begin{array}{l}90.1-2004 \text { design } \\
\text { with HP lamps and } \\
\text { ballasts }\end{array}$ & 1.24 & 1.24 & 13.3 \\
\hline Stairway & $2 \%$ & 0.6 & 6.5 & $\begin{array}{l}90.1-2004 \text { design } \\
\text { with HP lamps and } \\
\text { ballasts }\end{array}$ & 0.60 & 0.60 & 6.5 \\
\hline \multirow[t]{4}{*}{ Lobby } & $6 \%$ & 1.3 & 14.0 & $\begin{array}{l}\text { 90.1-2004 design } \\
\text { Modified }\end{array}$ & 1.09 & 1.09 & 11.7 \\
\hline & & & & Linear cove (20\%) & & & \\
\hline & & & & CFL pendant (30\%) & & & \\
\hline & & & & $\begin{array}{l}\text { CFL downlight } \\
(50 \%)\end{array}$ & & & \\
\hline Other & $6 \%$ & 1.0 & 10.8 & $\begin{array}{l}90.1-2004 \text { design } \\
\text { with HP lamps and } \\
\text { ballasts }\end{array}$ & 0.82 & 0.82 & 8.8 \\
\hline $\begin{array}{l}\text { Weighted LPD for } \\
\text { the whole building }\end{array}$ & $100 \%$ & 1.0 & 10.8 & & & 0.75 & 8.1 \\
\hline
\end{tabular}

(a) The floor area percentage for each space type is from a National Commercial Construction Characteristics Database developed by Pacific Northwest National Laboratory (Richman et al. 2008). 


\subsubsection{Occupancy Sensor Control}

Occupancy sensor control is included in the simulation for the advanced building models. To model occupancy sensor control, the peak lighting power density was reduced by $15 \%$ as supported in previous studies (Jarnagin et al. 2006; Jiang et al. 2008). In this work, a detailed analysis was made to quantify the potential of energy savings as a result of occupancy sensor control. Table 4.5 presents the breakdown of the lighting control strategies for each space category, the percentage of lights controlled by occupancy sensors, and the percentage of energy saving potential from occupancy sensors. The orange shaded rows indicate the spaces or the parts of lighting systems that use occupancy sensor control in the advanced case but not in the baseline. After calculation, it is found that because of the increased use of occupancy sensors, the advanced case has about $16.8 \%$ less lighting energy use than the baseline. Thus, in the EnergyPlus models for advanced cases, the peak lighting power density is reduced by $16.8 \%$, and this reduction applies for weekdays only. Figure 4.1 shows the comparison of weekday lighting schedules between the baseline without occupancy sensors and the advanced case with occupancy sensor.

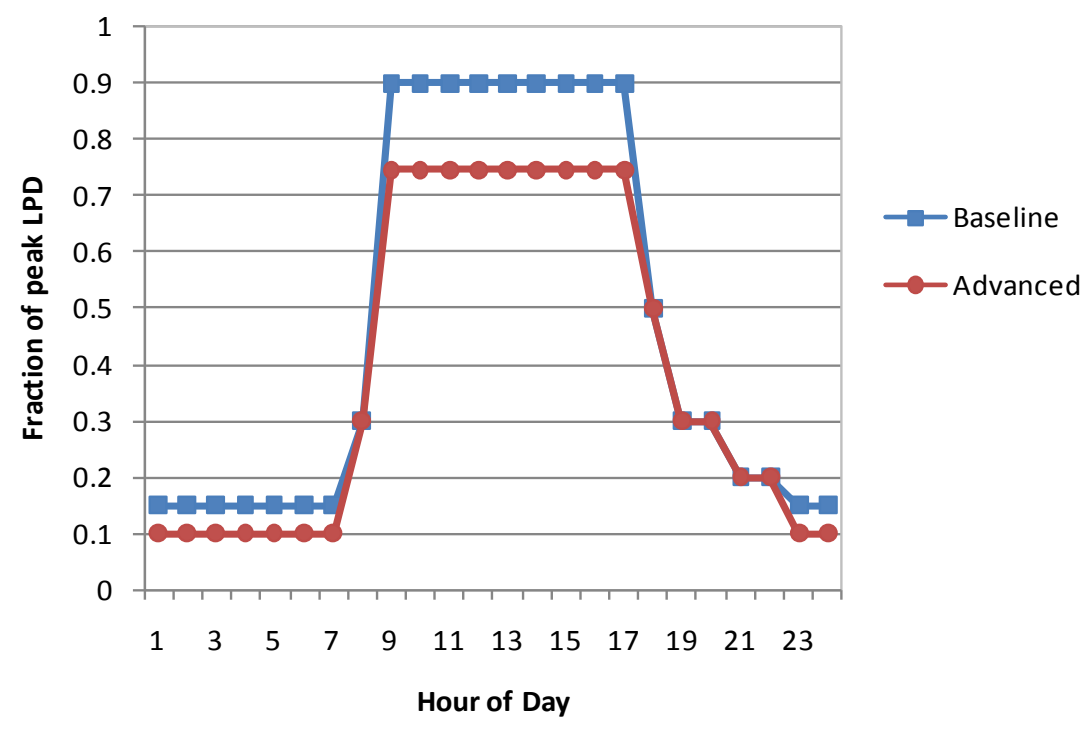

Figure 4.1. The Change of Interior Lighting Schedules from Occupancy Sensors 
Table 4.5. Lighting Energy Saving from the Increased Use of Occupancy Sensors

\begin{tabular}{|c|c|c|c|c|c|c|c|}
\hline \multirow[b]{2}{*}{ Space Type } & \multirow{2}{*}{$\begin{array}{c}\text { Area } \\
(\%)\end{array}$} & \multirow{2}{*}{$\begin{array}{l}\text { Lighting } \\
\text { Systems } \\
\end{array}$} & Lighting C & ntrol Strategy & \multirow[t]{2}{*}{$\begin{array}{c}\text { Lighting } \\
\text { power } \\
\text { controlled } \\
\text { by } \\
\text { occupancy } \\
\text { sensors } \\
(\%)\end{array}$} & \multirow[t]{2}{*}{$\begin{array}{l}\text { Lighting } \\
\text { energy } \\
\text { savings } \\
\text { due to } \\
\text { occupancy } \\
\text { sensor } \\
(\%)\end{array}$} & \multirow[b]{2}{*}{ Remarks } \\
\hline & & & Baseline & Advanced & & & \\
\hline Office- open plan & 16 & $\begin{array}{l}\text { task lighting } \\
\text { downlighting } \\
\text { ambient/ } \\
\text { uplight } \\
\text { ambient/ } \\
\text { daylight zone }\end{array}$ & $\begin{array}{l}\text { time } \\
\text { sweep } \\
\text { time } \\
\text { sweep } \\
\text { time } \\
\text { sweep } \\
\text { time } \\
\text { sweep }\end{array}$ & $\begin{array}{l}\text { occupancy } \\
\text { sensor } \\
\text { time sweep } \\
\text { photosensor/ } \\
\text { time sweep } \\
\text { photosensor/ } \\
\text { personal } \\
\text { dimming }\end{array}$ & 7 & 29 & (a) \\
\hline Office- private & 25 & ambient & $\begin{array}{l}\text { time } \\
\text { sweep }\end{array}$ & $\begin{array}{l}\text { occupancy } \\
\text { sensor }\end{array}$ & 100 & 33 & $(b, c)$ \\
\hline Conference meeting & 10 & $\begin{array}{l}\text { ambient } \\
\text { direct/ } \\
\text { indirect } \\
\text { linear wall } \\
\text { washing }\end{array}$ & $\begin{array}{l}\text { occupancy } \\
\text { sensor } \\
\text { occupancy } \\
\text { sensor }\end{array}$ & $\begin{array}{l}\text { occupancy } \\
\text { sensor } \\
\text { occupancy } \\
\text { sensor }\end{array}$ & 0 & 0 & \\
\hline Corridor/ Transition & 10 & $\begin{array}{l}\text { standard } \\
\text { design }\end{array}$ & $\begin{array}{l}\text { time } \\
\text { sweep }\end{array}$ & time sweep & 0 & 0 & \\
\hline Active storage & 15 & $\begin{array}{l}\text { standard } \\
\text { design }\end{array}$ & $\begin{array}{l}\text { time } \\
\text { sweep }\end{array}$ & $\begin{array}{l}\text { occupancy } \\
\text { sensor }\end{array}$ & 100 & 40 & (d) \\
\hline Restrooms & 4 & $\begin{array}{l}\text { standard } \\
\text { design }\end{array}$ & $\begin{array}{l}\text { time } \\
\text { sweep }\end{array}$ & $\begin{array}{l}\text { occupancy } \\
\text { sensor }\end{array}$ & 100 & 26 & (b) \\
\hline Lounge/Recreation & 3 & $\begin{array}{l}\text { standard } \\
\text { design }\end{array}$ & $\begin{array}{l}\text { occupancy } \\
\text { sensor }\end{array}$ & $\begin{array}{l}\text { occupancy } \\
\text { sensor }\end{array}$ & & & \\
\hline Electrical/Mechanical & 3 & $\begin{array}{l}\text { standard } \\
\text { design }\end{array}$ & $\begin{array}{l}\text { time } \\
\text { sweep }\end{array}$ & $\begin{array}{l}\text { occupancy } \\
\text { sensor }\end{array}$ & 100 & 40 & (d) \\
\hline Stairway & 2 & $\begin{array}{l}\text { standard } \\
\text { design }\end{array}$ & $\begin{array}{l}\text { time } \\
\text { sweep }\end{array}$ & time sweep & 0 & 0 & \\
\hline Lobby & 6 & $\begin{array}{l}\text { standard } \\
\text { design }\end{array}$ & $\begin{array}{l}\text { time } \\
\text { sweep }\end{array}$ & time sweep & 0 & 0 & \\
\hline Other & 6 & $\begin{array}{l}\text { standard } \\
\text { design }\end{array}$ & $\begin{array}{l}\text { time } \\
\text { sweep }\end{array}$ & time sweep & 0 & 0 & \\
\hline Total lighting energy & avings & from occupanc & y sensor con & & & $16.8 \%$ & \\
\hline $\begin{array}{l}\text { (a) Data from Galasiu } \\
\text { (b) Data from VonNe } \\
\text { (c) DiLouie (2009) } \\
\text { (d) Data from LRC (2 }\end{array}$ & $\begin{array}{l}\text { et al. (2 } \\
\text { da et al }\end{array}$ & $\begin{array}{l}007) \\
(2000)\end{array}$ & & & & & \\
\hline
\end{tabular}




\subsubsection{Improved Interior Lighting Power Management}

The lighting power management is improved in the advanced cases including greater use of occupancy sensors, as described in 4.2.1.2. The occupancy sensors are estimated to provide additional savings relative to sweep automated lighting controls in the baseline beyond that provided by the $16.8 \%$ reduction used in 4.2.1.2. Minimizing egress lighting, and locking out all use of egress lighting once a security system identifies a building is unoccupied will also reduce lighting during unoccupied hours. Adoption of occupancy sensors and for some buildings reduced egress lighting and/or security lock-out leads to the interior lighting schedule being reduced from 0.15 to 0.10 for unoccupied hours for the advanced case (Figure 4.1).

\subsubsection{Daylight Harvesting}

Daylight harvesting takes advantage of the available daylight to reduce electrical lighting energy consumption while maintaining desired levels of illumination. In the current development of the advanced models, only side daylighting was considered for the perimeter open office zones. No attempt was made to optimize glazing specifications or window layout, which is to be considered in future work. The daylighting dimming control was modeled in EnergyPlus with the following assumptions:

- The daylight zone extends $8 \mathrm{ft}$ (2.5 m) inward from the exterior walls (the assumed depth of one workstation).

- The lighting sensor lies at the center of each perimeter zone in the ceiling.

- In the daylight zones (perimeter open office zones), The ambient lighting system is dimmed in response to daylight. This was modeled in EnergyPlus by setting $75 \%$ of each daylight zone subject to dimming control.

- The dimming control system has an illuminance setpoint of 28 footcandles (300 lux) average for the space. The dimming controls are continuous. This continuous dimming control can dim down to $10 \%$ of maximum light output with a corresponding $10 \%$ of maximum power input.

\subsubsection{Exterior Lighting}

\subsubsection{Reduced Exterior Lighting Power Allowances}

For the medium office prototype, exterior lighting is estimated for parking areas, building entrances and exits, and building facades. In the advanced models, the exterior lighting power density was calculated according to the lighting power allowances prescribed by Addendum I to 90.1-2007. In comparison, the baseline exterior lighting power was set at the lighting power allowed by 90.1-2004. The major differences between these two approaches are as follows:

- The advanced case allows a base site allowance of 750 watts while the base case includes an additional unrestricted allowance equal to $5 \%$ of the sum of the individual exterior power density.

- The lighting power allowance for building facades is reduced in the advanced case to $50 \%$ of the Addendum I to 90.1-2007 allowance because façade lighting is a purely decorative effect and should be eliminated or reduced in buildings attempting to save energy. Façade lighting that is installed is assumed to be programmed to turn off between the hours of midnight and 5 AM. 
Table 4.6 shows the components of the exterior lighting power allowances for both the baseline and the advanced cases. Addendum I to 90.1-2007 assigns lighting power allowances for each exterior area type based on the location of the building in one of four exterior lighting zones:

- Zone 1 covers the developed areas of national or state parks, forest land, and other rural areas.

- Zone 2 covers the areas predominantly consisting of residential uses and neighborhood business districts with limited nighttime lighting.

- Zone 3 covers all other areas not covered by zones 1, 2 and 4.

- Zone 4 covers high activity commercial districts in major metropolitan areas and must be classified as such by the local jurisdiction.

For the purpose of this analysis, it is assumed that the building is located in lighting zone 3. The calculation is based on a number of inputs such as the percentage of parking areas, the number of main entrances and other doors, and the area for each façade. These inputs are from a variety of sources including a building database (Richman et al. 2008), Internet (e.g., Village of Wheeling 2009) and survey results (Richman 2008).

\subsubsection{Exterior Lighting Control}

Parking lot lighting is assumed to have bi-level switching ballasts that will reduce its power between $12 \mathrm{PM}$ and 6 AM. Façade lighting is also controlled to turn off between midnight and 6 AM. Therefore, in the advanced models, the exterior lighting is assumed to be controlled by a combination of photocell and time clock. The time clock sets the exterior lighting power at $10 \%$ of the design level when no occupants are present between $12 \mathrm{PM}$ and 6 AM. The photocell plays the role of turning off the exterior lights when the sun is up even if the scheduled lighting power is not zero. In contrast, for the base case, exterior lights are fully energized whenever it is dark outside. 
Table 4.6. Exterior Lighting Power Allowances

\begin{tabular}{|c|c|c|c|c|}
\hline \multirow[b]{2}{*}{ Items } & \multicolumn{2}{|c|}{ Baseline } & \multicolumn{2}{|c|}{ Advanced } \\
\hline & IP units & SI units & IP units & SI units \\
\hline Base site allowance, advanced case only W (W) & & & 750 & 750 \\
\hline \multicolumn{5}{|l|}{ Parking } \\
\hline parking area, $\mathrm{ft}^{2}\left(\mathrm{~m}^{2}\right)^{(\mathrm{a})}$ & 87,480 & 8,126 & 87,480 & 8,126 \\
\hline lighting power allowance for parking $\mathrm{W} / \mathrm{ft}^{2}\left(\mathrm{~W} / \mathrm{m}^{2}\right)$ & 0.15 & 1.6 & 0.10 & 1.1 \\
\hline total lighting power for parking, $\mathrm{W}(\mathrm{W})$ & 13,122 & 13,122 & 8,748 & 8,748 \\
\hline \multicolumn{5}{|l|}{ Walkways } \\
\hline walkway area, $\mathrm{ft}^{2}\left(\mathrm{~m}^{2}\right)^{(\mathrm{b})}$ & 4374 & 406 & 4374 & 406 \\
\hline lighting power allowance for walkway area $\mathrm{W} / \mathrm{ft}^{2}\left(\mathrm{~W} / \mathrm{m}^{2}\right)$ & 0.2 & 2.2 & 0.16 & 1.7 \\
\hline total lighting power for walkway area W (W) & 875 & 875 & 700 & 700 \\
\hline \multicolumn{5}{|l|}{ Building entrance and exits ${ }^{(c)}$} \\
\hline \multicolumn{5}{|l|}{ main entries } \\
\hline linear foot of door width for main entries, ft (m) & 16.2 & 4.9 & 16.2 & 4.9 \\
\hline lighting power allowance for main entries $\mathrm{W} / \mathrm{ft}(\mathrm{W} / \mathrm{m})$ & 30 & 98 & 30 & 98 \\
\hline canopy over entry, $\mathrm{ft}^{2}\left(\mathrm{~m}^{2}\right)$ & 48 & 4.5 & 48 & 4.5 \\
\hline lighting power allowance for canopy $\mathrm{W} / \mathrm{ft}^{2}\left(\mathrm{~W} / \mathrm{m}^{2}\right)$ & 1.25 & 13 & 0.4 & 4 \\
\hline total lighting power for main entries W (W) & 546 & 546 & 505 & 505 \\
\hline \multicolumn{5}{|l|}{ other doors } \\
\hline linear foot of door width for other doors, ft (m) & 40.7 & 12.4 & 40.7 & 12.4 \\
\hline lighting power allowance for other doors W/ft (W/m) & 20 & 66 & 20 & 66 \\
\hline canopy over entry $\mathrm{ft}^{2}\left(\mathrm{~m}^{2}\right)$ & 65 & 6.0 & 65 & 6.0 \\
\hline lighting power allowance for canopy $\mathrm{W} / \mathrm{ft}^{2}\left(\mathrm{~W} / \mathrm{m}^{2}\right)$ & 1.25 & 13.5 & 0.25 & 2.7 \\
\hline total lighting power for other doors W (W) & 895 & 895 & 830 & 830 \\
\hline total lighting power for building entrance and exits W (W) & 1,441 & 1,441 & 1335 & 1,335 \\
\hline \multicolumn{5}{|l|}{ Building facades $^{(\mathrm{d})}$} \\
\hline façade area lighted $\mathrm{ft}^{2}\left(\mathrm{~m}^{2}\right)$ & 21,294 & 1,978 & 21,294 & 1,978 \\
\hline lighting power allowance for building facades $\mathrm{W} / \mathrm{ft}^{2}\left(\mathrm{~W} / \mathrm{m}^{2}\right)$ & 0.2 & 2.2 & 0.075 & 0.8 \\
\hline total lighting power for building facades W (W) & 4,259 & 4,259 & 1,597 & 1,597 \\
\hline Sum of lighting power for all categories W (W) & 19,697 & 19,697 & 12,380 & 12,380 \\
\hline $5 \%$ additional allowance $\mathrm{W}(\mathrm{W})$ & 985 & 985 & - & - \\
\hline Total exterior lighting power $\mathrm{W}(\mathrm{W})$ & 20,682 & 20,682 & 13,130 & 13,130 \\
\hline \multicolumn{5}{|c|}{$\begin{array}{l}\text { (a) There are four parking spots per } 1000 \mathrm{ft}^{2}\left(92.9 \mathrm{~m}^{2}\right) \text { of building area. Each parking spot occupies } 405 \mathrm{ft}^{2}(37.6 \\
\mathrm{m}^{2} \text { ) including associated drives. } \\
\text { (b) Walkways are assumed to be } 5 \% \text { of the building square footage. Determined from site plans used in the } \\
\text { analysis of Addendum I to } 90.1-2007 . \\
\text { (c) There are about } 3.5 \text { doors per } 10,000 \mathrm{ft}^{2}\left(929 \mathrm{~m}^{2}\right) \text { of building area, one of which is the main entrance and the } \\
\text { rest are other doors. All doors have a width of } 3 \mathrm{ft}(0.29 \mathrm{~m}) \\
\text { (d) The lighting power allowance for building facades is reduced in the advanced case to } 50 \% \text { of the } 90.1-2007 \\
\text { addenda I allowance because façade lighting is a purely decorative effect and should be eliminated or reduced } \\
\text { in buildings attempting to save energy. }\end{array}$} \\
\hline
\end{tabular}




\subsection{Miscellaneous Equipment (plug loads)}

Miscellaneous electric equipment is a major energy end use sector. In office buildings, plug loads can account for about $25 \%$ of total onsite energy consumption (CBECS 2003). The above percentage may go higher as the building becomes more energy efficient. In the baseline medium office building models, miscellaneous electric equipment accounts for between $21 \%$ and $34 \%$ of total building energy use, depending on climate zone. In addition to their own electric energy requirement, miscellaneous equipment is also a major source of internal heat gains, which in turn increases cooling loads. With miscellaneous equipment responsible for such a large portion of building energy use, it is clear that reducing this end use must play an important role in achieving the goal of $50 \%$ energy savings for the whole building.

A reasonable estimation of the potential to reduce appliance energy consumption requires some detailed information such as the office equipment inventory, the electric power of market available highefficiency products, the power management strategy of the computer network and the potential for other control strategies. In developing the office equipment inventory for the advanced cases, the number of pieces of electric equipment is kept the same as those for the baseline cases, except for the mix of computers (see Section 3.5.4). In estimating the electric power of market-available high-efficiency equipment, the ENERGY STAR standard is used as a reference if that equipment is covered by the ENERGY STAR program; otherwise, a reasonable estimation of energy saving is made for the highefficiency equipment in the advanced cases.

The advanced case incorporates a number of strategies to reduce the energy usage from plug loads.

1. Shift towards a higher proportion of laptop computers relative to desktop computers - In the baseline, half the computers at workstations are desktop computers and half are laptop computers. The advanced case includes one third desktop computers and two thirds laptop computers. Laptop computers have lower power demand and better power management and use less energy. This is reflected in the quantity of computers of each type in Table 4.7.

2. Use of ENERGY STAR equipment including computers, monitors, printers, copy machines, fax machines, water coolers, and refrigerators - This is reflected in reduction in the power wattage of each device in proportion to the ENERGY STAR percentage savings. Note that vending machines are addressed in the control strategies in the next item.

3. Use of additional control software and equipment to further reduce energy usage beyond those required for ENERGY STAR and for equipment not covered by the ENERGY STAR label Additional controls result in further energy savings incorporated into the equipment usage schedules in the advanced models. The starting point for these reductions is the wattage determined from the previous two strategies. Table 4.8 shows the estimated energy reductions and the resulting adjusted schedule for the advanced cases.

a. Power management software for networked computers

b. Occupancy sensor controlled outlets including use of plug strips or whole room occupancy control (in conjunction with lighting) to control monitors, portable HVAC, and miscellaneous small appliances

c. Vending Miser occupancy sensor control 
d. Timer switches for coffee makers and water coolers

Table 4.7. Plug Load Calculation for the Advanced Case without Additional Controls

\begin{tabular}{|c|c|c|c|c|c|c|}
\hline \multirow[b]{2}{*}{ Plug Load Equipment Inventory } & \multicolumn{3}{|c|}{ Baseline } & \multicolumn{3}{|c|}{ Advanced } \\
\hline & Quantity & $\begin{array}{c}\text { Plug } \\
\text { load, } \\
\text { each }(W)\end{array}$ & $\begin{array}{l}\text { Plug load } \\
\text { (W) }\end{array}$ & Quantity & $\begin{array}{c}\text { Plug } \\
\text { load, } \\
\text { each }(W)\end{array}$ & Plug load (W) \\
\hline \multicolumn{7}{|l|}{ Office Equipment } \\
\hline Computers - servers & 8 & 65 & 520 & 8 & 54 & 432 \\
\hline Computers - desktop ${ }^{(a)}$ & 134 & 65 & 8,710 & 89 & 54 & 4,806 \\
\hline Computers - laptop ${ }^{(a)}$ & 134 & 19 & 2,546 & 179 & 17 & 3,043 \\
\hline Monitors - server - LCD & 8 & 35 & 280 & 8 & 24 & 192 \\
\hline Monitors - desktop - LCD & 268 & 35 & 9,380 & 268 & 24 & 6,432 \\
\hline Laser printer - network & 8 & 215 & 1,720 & 8 & 180 & 1,440 \\
\hline Copy machine & 4 & 1,100 & 4,400 & 4 & 500 & 2,000 \\
\hline Fax machine & 8 & 35 & 280 & 8 & 17 & 136 \\
\hline Water cooler & 8 & 350 & 2,800 & 8 & 193 & 1,544 \\
\hline Refrigerator & 8 & 76 & 608 & 8 & 65 & 520 \\
\hline Vending machine & 4 & 770 & 3,080 & 4 & 770 & 3,080 \\
\hline Coffee maker & 4 & 1,050 & 4,200 & 4 & 1,050 & 4,200 \\
\hline Portable HVAC (heaters, fans) & 30 & 30 & 900 & 30 & 30 & 900 \\
\hline Other small appliances, chargers & 250 & 4 & 1,000 & 250 & 4 & 1,000 \\
\hline Total plug load (W) & & & 40,424 & & & 29,725 \\
\hline Plug load density, W/ft ${ }^{2}\left(\mathrm{~W} / \mathrm{m}^{2}\right)$ & & & $0.75(8.07)$ & & & $0.55(5.92)$ \\
\hline
\end{tabular}

(a) Assumes shift towards higher proportion of laptops instead of desktop computers in advanced from earlier equipment power density.

Strategy 1-Shift towards laptop computers One way to significantly reduce energy from computers is to move towards laptop computers. This may also be a precursor to a potential movement to simpler terminal units that operate primarily from web and network-based software. This strategy is modeled for the advanced case by increasing the proportion of computers that are laptops to two thirds from one half in the baseline.

Strategy 2-Use of ENERGY STAR equipment The use of ENERGY STAR equipment is developed by the reduction in the power associated with each type of equipment as shown in Table 4.7 and described as follows:

- For desktop computers, monitors, printers, copy machines, fax machines, water coolers, and refrigerators, there are ENERGY STAR labeled products. In addition, a savings calculator is provided at the website (EPA 2009) for each category to estimate the percentage of energy savings in comparison with the corresponding conventional, non ENERGY STAR labeled products. In this case, that percentage of energy saving is used as a factor of the baseline plug load per unit in Table 3.3 to calculate the plug load in Table 4.7. For example, the saving calculator for fax machines indicate that an ENERGY STAR labeled fax machine consumes about $49 \%$ less annual energy use 
than a conventional unit. Thus, the plug load for a high-efficiency fax machine is calculated as $35 * 49 \%=17 \mathrm{~W}$, where the number of $35 \mathrm{~W}$ represents a conventional fax machine's plug load in Table 3.3.

- For laptop computers, although there are ENERGY STAR labeled products, no savings calculator was found available to calculate energy savings. In this case, it is assumed that an ENERGY STAR labeled laptop computer achieves $10 \%$ energy saving in comparison with a conventional laptop.

- The above procedure reduces the peak plug load density from $0.75 \mathrm{~W} / \mathrm{ft}^{2}\left(8.07 \mathrm{~W} / \mathrm{m}^{2}\right)$ in the baseline to $0.55 \mathrm{~W} / \mathrm{ft}^{2}\left(5.92 \mathrm{~W} / \mathrm{m}^{2}\right)$ in the advanced cases. The plug load schedule is not changed with this step in the savings strategies because no additional controls are incorporated. These two strategies result in a $26.5 \%$ reduction in plug load energy usage. Note that plug load energy reduction interacts with HVAC energy usage so the effective percentage reduction in energy may be different in the complete energy usage for each model.

Strategy 3-Additional controls Additional controls are included - power management software particularly at the network level, occupancy sensor controls of monitors and other equipment at workstations and other office areas, Vending Miser, and timer switches for coffee makers and water coolers. Note that timer switches may also be worthwhile for network printers and copiers, although no credit is taken for application to those devices. Table 4.8 shows the estimated energy reductions. Reductions in energy for these strategies will not occur evenly throughout the day and will be largest during periods when occupancy is low or none. Table 4.9 shows how the energy usage is captured by altering the schedule, particularly during low or no occupancy periods. This strategy reduces total plug energy usage by an additional $18.8 \%$ below that achieved by the first two strategies that directly reduced the power per square foot. This results in an additional 13.7\% from total plug energy. Note that plug load energy reduction interacts with HVAC energy usage so the effective percentage reduction in energy may be different in the complete energy usage for each model.

Estimating potential reductions for these strategies beyond those achieved by ENERGY STAR and altering the mix of laptop and desktop computers is based on information regarding how much of the time equipment is left on when not in use, proportion of equipment that already has power management software, and estimated savings from several sources. This is a rough estimate; much is not known or up to date on actual current equipment energy usage (as opposed to connected power) and the use of controls in current new buildings for a baseline. The estimates in Table 4.8 are based on several sources (Sanchez et al. 2007, Rivas 2009, EPA 2009). The schedule reductions in Table 4.9 by time period are estimated to achieve the same level of savings as that determined in Table 4.8, weighted towards low and no occupancy hours. The baseline schedule is shown for comparison.

Table 4.9 shows the schedule that is used for the baseline, and then is modified to apply to the advanced case plug load power as determined in Table 4.7. The weighted by time period columns estimate the total energy for plug loads that occur during each schedule block. This is approximate because the weighting for Sunday is for 1 day in 7 and does not account for holidays. 
Table 4.8. Estimated Additional Reduction in Plug Loads Energy Usage with Controls

\begin{tabular}{|c|c|c|c|c|c|c|}
\hline \multirow[b]{2}{*}{ Plug Load Equipment Inventory } & \multicolumn{4}{|c|}{$\begin{array}{l}\text { Advanced, with shift to laptops and ENERGY } \\
\text { STAR }\end{array}$} & \multicolumn{2}{|c|}{$\begin{array}{c}\text { Reductions in Plug Loads } \\
\text { with Controls }\end{array}$} \\
\hline & Qty. & $\begin{array}{c}\text { Plug load } \\
\text { per unit } \\
\text { (W/unit) }\end{array}$ & $\begin{array}{l}\text { Plug load } \\
\text { (W) }\end{array}$ & $\begin{array}{l}\% \text { of } \\
\text { total } \\
\text { watts }\end{array}$ & $\begin{array}{c}\text { Estimated } \\
\text { Reduction } \\
\%\end{array}$ & $\begin{array}{l}\text { Reduction in } \\
\text { total plug } \\
\text { energy, \% }\end{array}$ \\
\hline \multicolumn{7}{|l|}{ Office Equipment } \\
\hline Computers - servers & 8 & 54 & 432 & 1.5 & 0.0 & 0.0 \\
\hline Computers - desktop & 89 & 54 & 4,806 & 16.2 & 25.0 & 4.0 \\
\hline Computers - laptop & 179 & 17 & 3,043 & 10.2 & 7.5 & 0.8 \\
\hline Monitors - server - LCD & 8 & 24 & 192 & 0.6 & 0.0 & 0.0 \\
\hline Monitors - desktop - LCD & 268 & 24 & 6,432 & 21.6 & 7.5 & 1.6 \\
\hline Laser printer - network & 8 & 180 & 1,440 & 4.8 & 0.0 & 0.0 \\
\hline Copy machine & 4 & 500 & 2,000 & 6.7 & 0.0 & 0.0 \\
\hline Fax machine & 8 & 17 & 136 & 0.5 & 0.0 & 0.0 \\
\hline Water cooler & 8 & 193 & 1,544 & 5.2 & 20.0 & 1.0 \\
\hline Refrigerator & 8 & 65 & 520 & 1.7 & 0.0 & 0.0 \\
\hline Vending machine & 4 & 770 & 3,080 & 10.4 & 50.0 & 5.2 \\
\hline Coffee maker & 4 & 1,050 & 4,200 & 14.1 & 20.0 & 2.8 \\
\hline Portable HVAC (heaters, fans) & 30 & 30 & 900 & 3.0 & 50.0 & 1.5 \\
\hline Other small appliances, chargers & 250 & 4 & 1,000 & 3.4 & 50.0 & 1.7 \\
\hline Plug load density W/ft ${ }^{2}\left(\mathrm{~W} / \mathbf{m}^{2}\right)$ & & & $0.55(5.92)$ & 100.0 & & 18.7 \\
\hline
\end{tabular}

Table 4.9. Changes in Plug Equipment Schedules with Added Controls

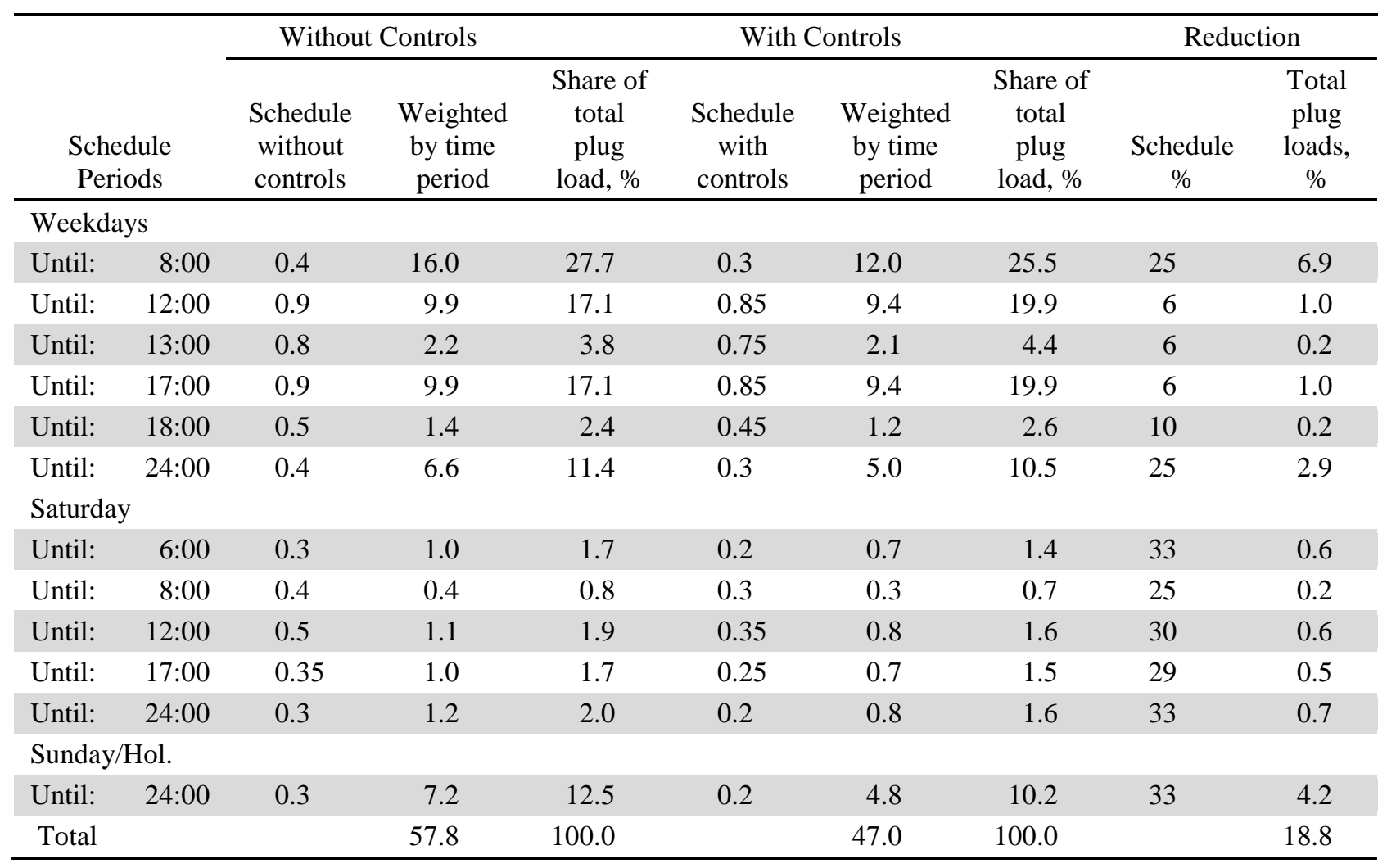




\subsection{HVAC Systems}

To achieve the 50\% energy saving goal, the packaged VAV system was replaced by a dedicated outdoor air system (DOAS) in combination with a hydronic radiant cooling and heating system. This section presents the system setup and the related energy efficiency measures for both the DOAS and the radiant thermal system.

\subsubsection{Dedicated Outdoor Air System}

In this study, the DOAS is used to condition and deliver the required outdoor ventilation air to each individual zone. It is also used to address the outdoor and space latent cooling loads. As mentioned in Mumma (2001) and Jeong et al. (2003), a DOAS combined with a parallel mechanical system has the following two major advantages in comparison with a conventional VAV system:

- DOAS can ensure that the required amount of outdoor ventilation air is distributed to every space, while a conventional VAV system cannot easily meet the ventilation requirement for all spaces. The difficulty of meeting ventilation requirement for conventional VAV systems has been observed in the baseline model. It was found that even after the VAV terminal box minimum settings were increased from 0.3 up to 0.7 for some zones, there are still many hours with insufficient supply of ventilation air.

- DOAS has more potential to save energy than a conventional VAV system. The great energy saving potential of DOAS comes from two aspects. First, it removes the necessity of excess outdoor air flow or system supply air flow, which is normally required for a conventional VAV system to meet ASHRAE Standard 62.1-2004. Thus, DOAS can save the energy used for processing that excess amount of air flow. Second, DOAS uses less energy for terminal reheating than a conventional VAV system. Because ventilation air is only part of the supply air for a conventional VAV system, the supply air flow rate to each space is larger than that for a DOAS. This means that a VAV system consumes more terminal reheating energy than a DOAS supplying air at the same temperature.

Different configurations of DOAS are available and have been studied in literature. Mumma and Shank (2001) compared five different component arrangements of the DOAS system in terms of their energy performance. They found that the DOAS system (Figure 4.2) consisting of a preheat coil, an enthalpy wheel, a deep cooling coil and a sensible heat exchanger (e.g., a sensible wheel) performs best. McDowell and Emmerich (2005) investigated the energy performance of two DOAS configurations for a building with a water source heat pump system. One DOAS simply consists of a preheat coil and an enthalpy wheel, while the other DOAS has the same configuration as shown in Figure 4.2. They found that the latter DOAS setup performs better but has only about 1-7\% more energy saving than the simple DOAS setup. 


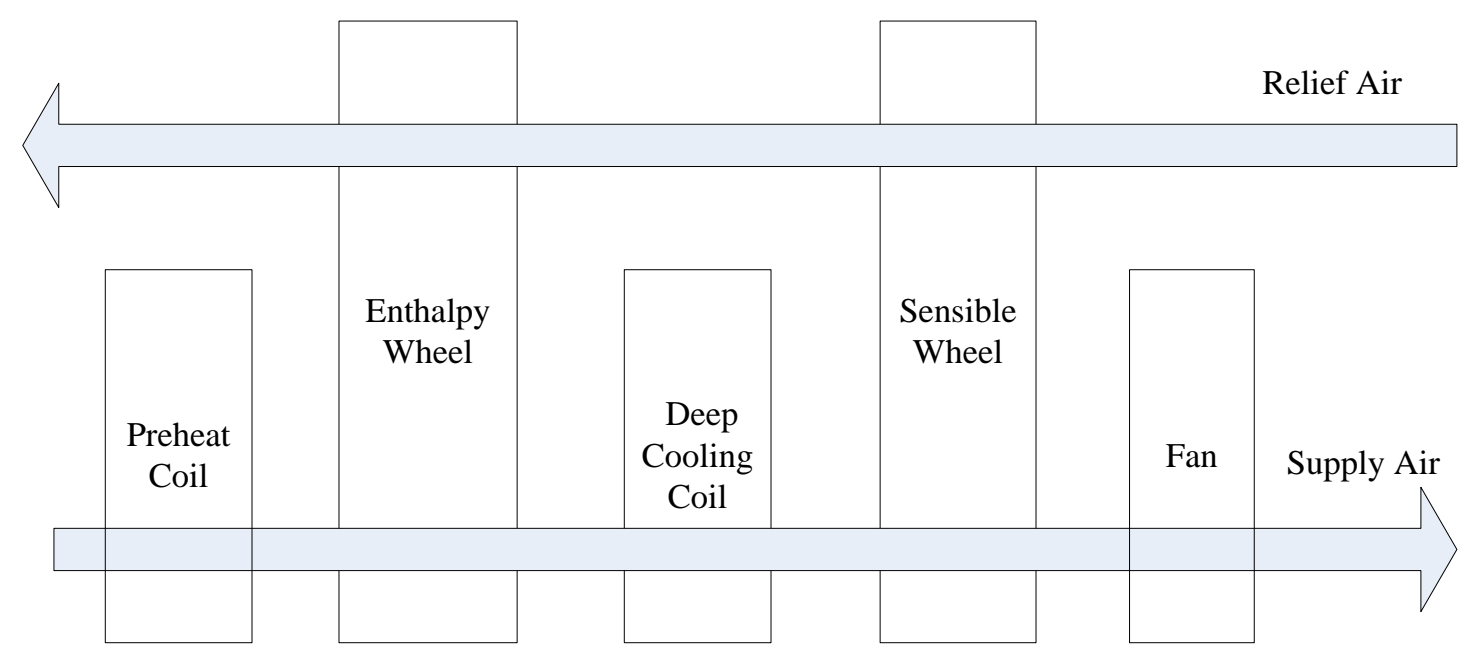

Figure 4.2. DOAS With Dual Wheels and Deep Cooling Coil

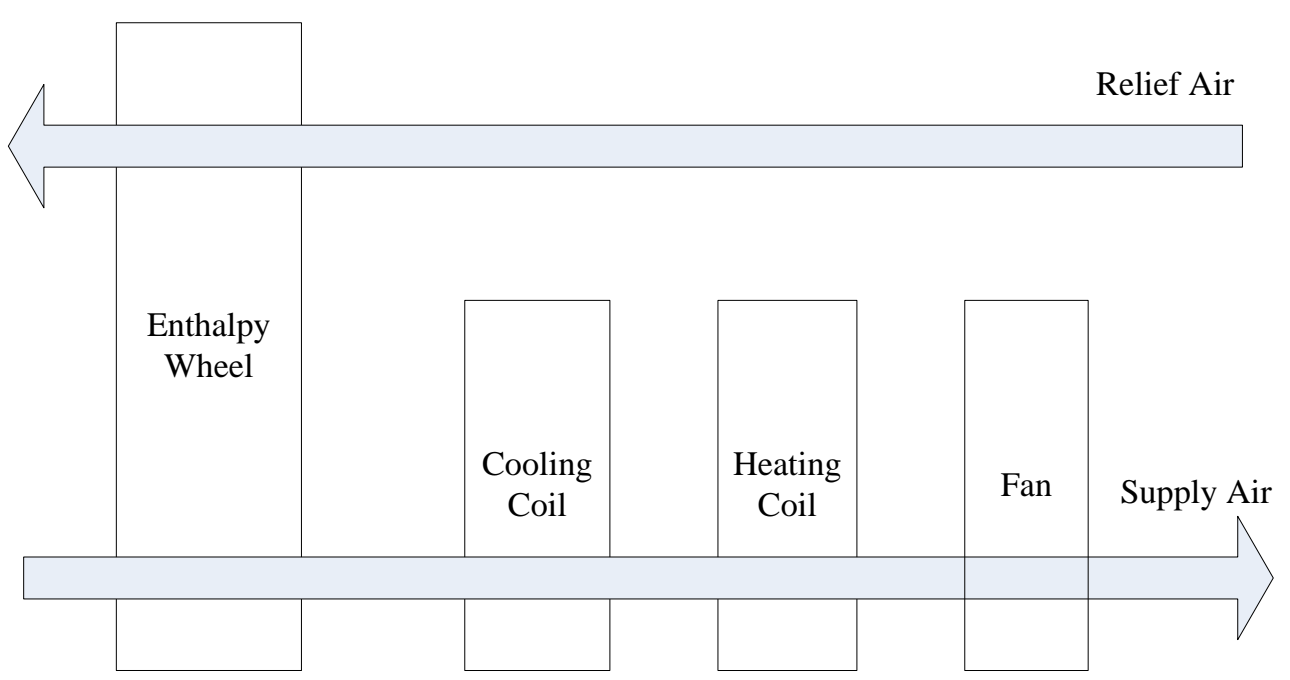

Figure 4.3. DOAS With Enthalpy Wheel, Conventional Cooling Coil and Heating Coil

Two alternative DOAS configurations are employed in this study depending on climate zones. For hot and humid climate zones (1A, 2A, 3A, and 4A), the DOAS configuration shown in Figure 4.2 is used. For other climate zones, the DOAS shown in Figure 4.3 is used and it consists of an enthalpy wheel, a cooling coil and a heating coil. The DOAS operates with the following major points:

- For the climate zones from $1 \mathrm{~A}$ to $3 \mathrm{C}$, the DOAS supply air temperature is maintained at $55^{\circ} \mathrm{F}$ $\left(12.8^{\circ} \mathrm{C}\right.$ ). For other climate zones (from 4A to 8 ), the DOAS supply air temperature is reset according to the outdoor air temperature. The reset rule is: the supply air temperature is at $55^{\circ} \mathrm{F}$ 
$\left(12.8^{\circ} \mathrm{C}\right)$ when the outdoor air temperature is at $64^{\circ} \mathrm{F}\left(18^{\circ} \mathrm{C}\right)$ or higher; it is at $62^{\circ} \mathrm{F}\left(16.7^{\circ} \mathrm{C}\right)$ when the outdoor air temperature is at $50^{\circ} \mathrm{F}\left(10^{\circ} \mathrm{C}\right)$ or lower; it is linearly interpolated when the outdoor air temperature is between $64^{\circ} \mathrm{F}\left(18^{\circ} \mathrm{C}\right)$ and $50^{\circ} \mathrm{F}\left(10^{\circ} \mathrm{C}\right)$.

- DX cooling coil is used for cooling in the considered DOAS configurations. For the configuration shown in Figure 4.2, deep cooling is employed with the temperature after cooling coil set at $45^{\circ} \mathrm{F}$ $\left(7.2^{\circ} \mathrm{C}\right)$. For the configuration shown in Figure 4.3, deep cooling is not employed and the temperature after cooling coil is set by accounting for the system supply air temperature setpoint and the temperature rise caused by fan energy input. Deep cooling is not necessary for those climate zones not represented as hot and humid. This has been verified by investigating the simulation results for Chicago in climate zone 5A: EnergyPlus simulation program shows that the humidity ratio lies in the comfort zone for almost all occupied hours and there is almost no surface condensation on the radiant floor.

- Energy recovery ventilation (ERV) is an energy efficient measure to reclaim energy from exhaust airflows to precondition the outdoor ventilation airflows. With a rotary heat exchanger added before the air handling unit, both heat and moisture can transfer between the exhaust air and the outdoor air. Offsetting the savings from the ERV is an increase in fan energy required to overcome the additional static pressure of the device and the parasitic energy for the enthalpy wheel rotation. In the advanced model, it is assumed that the enthalpy wheel has a pressure drop of 1.5 in. w.c (375 Pa) and a parasitic power of $200 \mathrm{~W}$. Table 4.10 shows the rated performance of the energy recovery ventilators from the product catalogues. Because ERV involves a trade off between reduced heating/cooling coil energy and the additional energy consumption by the supply fan and the rotary wheel motor, parametric simulation runs were pursued to investigate whether ERV has net energy savings. It is found that ERV has net energy savings in all climate locations except Los Angeles (climate zone 3B-CA) and San Francisco (zone 3C). Therefore, ERV is used in all climate zones except 3B-CA and 3C.

Table 4.10. Rated Performance of the Energy Recovery Ventilators

\begin{tabular}{lccc}
\hline & \multicolumn{3}{c}{ Effectiveness } \\
Condition & Sensible & Latent & Total \\
\hline heating @ 100\% air flow & 68 & 61 & 65 \\
heating @ 75\% air flow & 72 & 67 & 71 \\
\hline cooling @ 100\% air flow & 68 & 61 & 64 \\
\hline cooling @ 75\% air flow & 72 & 67 & 70 \\
\hline
\end{tabular}

- The air temperature after the enthalpy wheel is controlled to avoid overheating of the outdoor air. This was achieved in EnergyPlus with an outdoor air pretreat setpoint manager. This setpoint manager determines the desired temperature in the outdoor air stream by accounting for the mixed air setpoint and the mixing air conditions.

- Preheating coil is not explicitly used in the DOAS to avoid frost formation on the enthalpy wheel. Instead, the frost control was achieved by monitoring the temperature of the secondary air leaving the enthalpy wheel. If the exhaust air temperature is below the minimum setpoint of $1.7^{\circ} \mathrm{C}$, the enthalpy wheel rotation will slow down with reduced heat exchanger effectiveness. Frost control is modeled with the minimum exhaust air temperature solely for the purpose of simplicity because no preheating coil needs to be added to the DOAS. 
It needs to be mentioned that the dual wheel DOAS system (Figure 4.2) cannot be modeled properly in EnergyPlus version 3.0. The major difficulty lies in the lack of supply air temperature control for a sensible wheel. Thus, whenever the sensible wheel is in operation, the DOAS supply air temperature goes out of control. To address this problem, the dual wheel DOAS system is simulated in EnergyPlus by replacing the sensible wheel with an electric heating coil. With this change, the dual wheel DOAS turns into the same configuration as Figure 4.3 except for the use of a deep cooling coil. This changed DOAS can be modeled in EnergyPlus. However, part of the heating coil energy is consumed to heat up the deep cooled air to the system supply air temperature. This situation occurs only in cooling season and that part of heating energy could have been avoided by using a sensible wheel. Thus, for the dual wheel DOAS configuration, the work-around solution may result in underestimated energy savings than the actual design.

\subsubsection{Radiant Heating and Cooling System}

Initially, the analysis work for medium office proposed to achieve $50 \%$ energy savings with VAV systems. It became clear later that the advanced VAV system, along with the rest of the energy measures, would not be adequate to reach $50 \%$ in all climate locations. Within this context, hydronic radiant heating and cooling was proposed as an alternative to replace the baseline VAV system. In comparison with the conventional VAV system, the hydronic radiant thermal system has the following major advantages. First, the radiant system can significantly reduce fan energy because it uses water instead of air as the medium for energy transfer. Transporting water via pumps is much more energy efficient than transporting air via fans. Second, the radiant system usually reduces heating and cooling energy because the low temperature hot water and high temperature cold water are helpful to improve the heating and cooling efficiency of the corresponding equipment. Third, the radiant system has the potential to improve occupants' thermal comfort.

Radiant system design and application are still in development in the United States, while they are more widely adopted in Europe. Unlike VAV systems, there is no well established radiant system design. Building surfaces used in a radiant system can be floors, ceilings, and walls, though the first two are most commonly applied. Different radiant surfaces have different heating and cooling capacities. A radiant floor system has a larger heating capacity than its cooling capacity because radiant floor heating has a larger heat exchange coefficient between the floor and the space than radiant floor cooling. According to Babiak et al. (2009), a radiant floor system normally has a maximum heating capacity of about $100 \mathrm{~W} / \mathrm{ft}^{2}$ $\left(1075 \mathrm{~W} / \mathrm{m}^{2}\right)$ and a maximum cooling capacity of about $40 \mathrm{~W} / \mathrm{ft}^{2}\left(430 \mathrm{~W} / \mathrm{m}^{2}\right)$. In areas exposed to direct sunlight, the radiant cooling capacity can increase up to $100 \mathrm{~W} / \mathrm{ft}^{2}\left(1075 \mathrm{~W} / \mathrm{m}^{2}\right)$. However, floor carpets may reduce the heating and cooling capacity by as much as $50 \%$. In contrast to a radiant floor system, a radiant ceiling has a maximum heating capacity of about $40 \mathrm{~W} / \mathrm{ft}^{2}\left(430 \mathrm{~W} / \mathrm{m}^{2}\right)$ and a maximum heating capacity of about $100 \mathrm{~W} / \mathrm{ft}^{2}\left(1075 \mathrm{~W} / \mathrm{m}^{2}\right)$ (Babiak et al. 2009). Whatever radiant surface is used, unmet heating or cooling load may be supplemented by decentralized conventional air systems or dedicated outdoor air systems.

A hydronic radiant floor system is selected for both heating and cooling in this study. The radiant floor system is used because it can be modeled in a straightforward way in EnergyPlus. Although a radiant floor system may not be appropriate for some locations due to its cooling capacity or cost effectiveness issues, it is expected that the findings from the radiant floor system could provide a reasonable general evaluation of the energy saving potential of radiant systems. 
The modeled radiant floor system has the following major features:

- Water tubes made of cross-linked polyethylene are embedded in the screed for heating and cooling (Babiak et al. 2009). Figure 4.4 and 4.5 illustrates the construction for the slab-on-grade floor and the floating floor, respectively. A number of simulation runs are used to determine a suitable floor insulation level. Thus, different thicknesses were tried for the expanded polystyrene insulation and the one beyond which no noticeable energy savings can be observed is selected. For the slab-onground floor, there are two different insulation levels depending on the climate zone: expanded polystyrene with a thickness of 1.5 inch $(38 \mathrm{~mm}$ ) is used for climate zones 3A, 4A, 5A, 7 and 8, whereas a thickness of 1inch $(25 \mathrm{~mm})$ is used in other climate zones. For the floating floor, a thickness of 1inch $(25 \mathrm{~mm})$ is used for all climate zones.
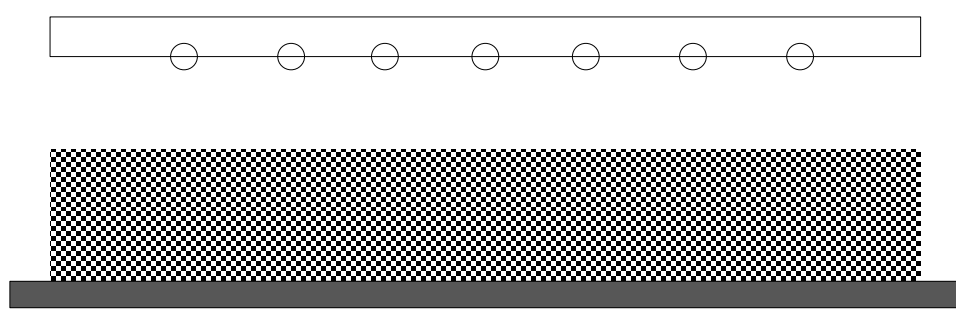

Figure 4.4. Slab-on-Grade Floor Construction
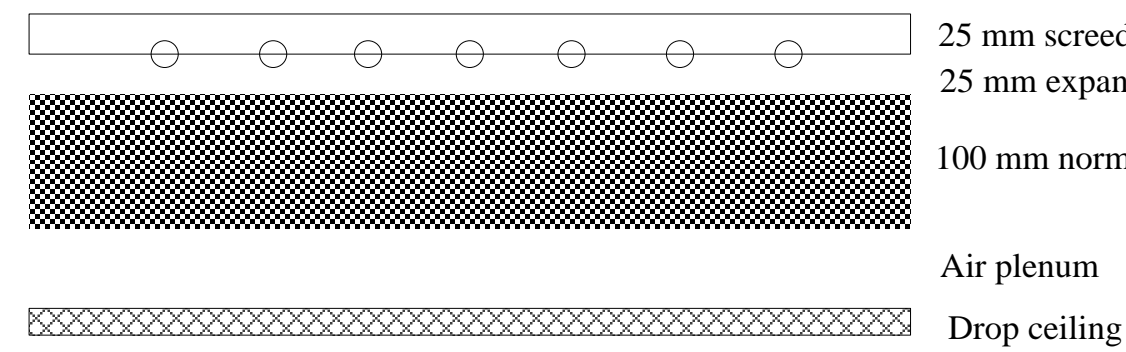

$25 \mathrm{~mm}$ screed

$25 \mathrm{~mm}$ expanded polystyrene

$100 \mathrm{~mm}$ normal weight concrete

Drop ceiling

Figure 4.5. Floating Floor Construction

- A condensing boiler and an air-cooled chiller are used, respectively, to provide hot water and chilled water to the radiant floor system. The supply hot water temperature is $113^{\circ} \mathrm{F}\left(45^{\circ} \mathrm{C}\right)$ and the supply chilled water temperature is $59^{\circ} \mathrm{F}\left(15^{\circ} \mathrm{C}\right)$. The supply water temperatures are thus set with two major considerations. First, the floor surface temperature must lie in the comfort range: the maximum surface temperature is $84^{\circ} \mathrm{F}\left(29^{\circ} \mathrm{C}\right)$ for heating and the minimum temperature is $66^{\circ} \mathrm{F}\left(19^{\circ} \mathrm{C}\right)$ for cooling (Olesen 2002, 2008). Second, the temperature is set to avoid surface condensation in cooling seasons.

- Variable flow/fixed temperature is the strategy used to control the radiant system in all thermal zones. This control is accomplished by defining a setpoint and a throttling range for the chosen temperature type (i.e., mean air temperature and operative temperature). The flow rate varies linearly to a thermal zone. It reaches the maximum when the controlled temperature gets above (for cooling) or below (for heating) the setpoint by half of the throttling range. There is no flow when the controlled temperature gets below (for cooling) or above (for heating) the setpoint by half of the throttling range. In the advanced models, mean air temperature is used to control the water flow rate of the radiant system, and it has a throttling range of $3.6^{\circ} \mathrm{F}\left(2^{\circ} \mathrm{C}\right)$. Figure 4.6 shows the mean air temperature setpoint used to control the water flow rate. 


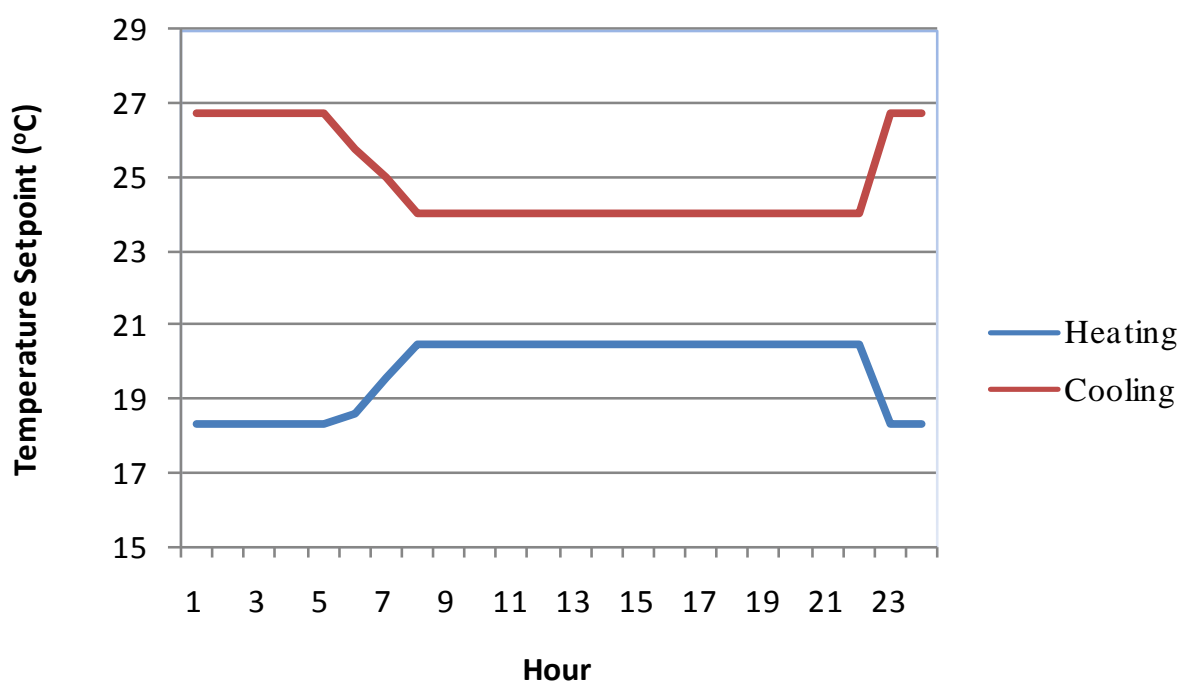

Figure 4.6. Weekday Schedule of the Mean Air Temperature Setpoint

Occupants' thermal comfort in office buildings mainly depends on operative temperature, which is basically the average of air temperature and mean radiant temperature. In comparison with the VAV system, the radiant system has a lower floor surface temperature for cooling and a higher surface temperature for heating. This means that the radiant system can achieve the same level of operative temperature at a lower air temperature for heating and a higher air temperature for cooling (Olesen 2002 and Babiak et al. 2009). Therefore, in the advanced models, the thermostat setpoint is decreased from $70^{\circ} \mathrm{F}\left(21^{\circ} \mathrm{C}\right)$ to $67^{\circ} \mathrm{F}\left(19.6^{\circ} \mathrm{C}\right)$ for heating. The cooling setpoint is not increased, and it maintains at $75^{\circ} \mathrm{F}$ $\left(24^{\circ} \mathrm{C}\right)$. This is mainly because solar radiation can substantially increase the cooling load in east- and west- oriented perimeter zones in a short period of time. Increasing cooling setpoint poses a further challenge for thermal comfort in those zones.

Simulations show that the maximum radiant floor heating capacity is not exceeded except for a few perimeter zones on the top floor in cold climates. However, it is found that radiant floor system cooling capacity is often not sufficient to meet the cooling load for east- and west-oriented perimeter zones with a large window area (recall that a window-to-wall ratio of 0.33 is used in the medium office building prototype). As a result, those perimeter zones have their mean air temperature above the cooling setpoint for many time steps. Despite the above unmet cooling setpoint issue, the radiant floor system is capable of maintaining a comparable operative temperature in east- and west-oriented perimeter zones as those for the baseline VAV system.

\subsubsection{Premium HVAC Equipment Efficiency}

The advanced models cover the following premium HVAC equipment: the packaged air conditioner for the DOAS, fan motors, the air-cooled chiller, and the gas-fired boiler.

The premium air conditioner is selected from the updated product engineering catalogue databases maintained by California Energy Commission (CEC 2009). In the selection process, attention has been paid to make sure that the selected efficiency represents the products from at least two manufacturers. Table 4.11 lists the selected higher cooling efficiency in terms of SEER or EER. Since COP is the 
required input in EnergyPlus, the corresponding COP values are also presented in this table, and they are calculated using the same method as presented in Section 3.6.5. The efficiency of the gas furnace for central heating in the packaged units is not improved in the current stage. Packaged units with higher gas furnace efficiency may be explored in future work.

Table 4.11. Higher Efficiency for Packaged Unitary Air Conditioners for the Advanced Case

\begin{tabular}{lcc}
\multicolumn{1}{c}{ Size Category } & $\begin{array}{c}\text { Efficiency } \\
\text { (SEER/EER) }\end{array}$ & $\begin{array}{c}\text { EnergyPlus } \\
\text { Input (COP) }\end{array}$ \\
\hline$<65,000 \mathrm{Btu} / \mathrm{h}(<19 \mathrm{~kW})$ & $13.5 \mathrm{SEER}$ & 4.02 \\
$65,000 \sim 135,000 \mathrm{Btu} / \mathrm{h}(19 \sim 40 \mathrm{~kW})^{(\text {a) }}$ & $11.5 \mathrm{EER}$ & 3.97 \\
$135,000 \sim 240,000 \mathrm{Btu} / \mathrm{h}(40 \sim 70 \mathrm{~kW})^{(\text {a) }}$ & $11.3 \mathrm{EER}$ & 3.90 \\
$240,000 \sim 300,000 \mathrm{Btu} / \mathrm{h}(70 \sim 88 \mathrm{~kW})$ & $10.5 \mathrm{EER}$ & 3.63 \\
$300,000 \sim 760,000 \mathrm{Btu} / \mathrm{h}(88 \sim 223 \mathrm{~kW})$ & $10.2 \mathrm{EER}$ & 3.53 \\
$\geq 760,000 \mathrm{Btu} / \mathrm{h}(\geq 223 \mathrm{~kW})$ & $9.5 \mathrm{EER}$ & 3.30 \\
\hline (a) The size range applies to the DOAS in this work
\end{tabular}

The improved motor efficiency is based on the premium-efficiency motors initiative launched by the Consortium for Energy Efficiency (CEE 2003). Table 4.12 lists the motor efficiency requirement together with the corresponding nameplate motor horsepower. The values in the table assume enclosed motors operating at $1,800 \mathrm{rpm}$.

Table 4.12. Improved Motor Efficiency

\begin{tabular}{cccccccccccccc}
\hline $\begin{array}{c}\text { Motor hp } \\
(\mathrm{kW})\end{array}$ & 1 & 2 & 5 & 10 & 15 & 20 & 30 & 40 & 50 & 60 & 125 & 150 & 200 \\
& $(0.7)$ & $(1.5)$ & $(3.7)$ & $(7.5)$ & $(11.2)$ & $(14.9)$ & $(22.4)$ & $(29.8)$ & $(37.3)$ & $(44.7)$ & $(93.2)$ & $(112)$ & $(149)$ \\
\hline Efficiency (\%) & 85.5 & 86.5 & 89.5 & 91.7 & 92.4 & 93 & 93.6 & 94.1 & 94.5 & 95 & 95.4 & 95.8 & 96.2 \\
\hline
\end{tabular}

In the advanced models, the air-cooled chiller has a rated COP of 3.1, which is available from multiple manufactures. The condensing gas-fired boiler has a thermal efficiency of $95 \%$, which is achievable for many ENERGY STAR labeled boilers (EPA 2009).

\subsubsection{Motorized Outdoor Air Damper Control}

The advanced case adds motorized outdoor air dampers in climate zones (zones 1, 2, and 3) where gravity dampers are allowed by 90.1-2004. Motorized dampers allow the outdoor air intake to be shut off during unoccupied periods. There is some difference in the strategy of modeling motorized outdoor air damper control between the baseline and the advanced cases. The minimum outdoor air schedule is used in the baseline to match the occupancy schedule, while the DOAS availability schedule is used in the advanced cases. This means that the DOAS is available for occupied hours and not available for unoccupied hours. 


\subsubsection{Demand-Controlled Ventilation}

Demand-controlled ventilation (DCV) modulates the amount of outdoor ventilation air in response to the actual occupancy in a zone as it varies throughout the day. DCV can be accomplished by using sensors that measure the $\mathrm{CO}_{2}$ changes in occupied spaces, which is a good proxy for the number of occupants present. EnergyPlus models DCV by dynamically resetting the minimum outdoor ventilation rate based on the floor area and varying number of people. Based on ASHRAE Standard 62.1-2004 (ANSI/ASHRAE 2004), the minimum ventilation rate per unit floor area is $0.06 \mathrm{cfm} / \mathrm{ft}^{2}\left(3.05 \mathrm{E}-4 \mathrm{~m} / \mathrm{s} / \mathrm{m}^{2}\right.$ ) and the minimum ventilation rate per person is $5 \mathrm{cfm} /$ person (2.36E-3 $\mathrm{m}^{3} / \mathrm{s} /$ person) for office buildings.

Although the DCV concept is simple, there is no straightforward approach to model DCV for a DOAS serving multiple zones in the current version of EnergyPlus. Hence, the DCV is modeled in this work with the following work-around approach: the ventilation rate per person is first discounted by the weighted average of occupancy schedule between 8:00 AM and 10:00 PM; then the discounted ventilation rate per person is used together with the ventilation rate per floor area to calculate the required ventilation for each zone.

\subsection{Alternative HVAC Systems - Variable Air Volume}

In addition to the hydronic radiant system presented in previous section, an improved VAV system was also investigated to estimate how much energy saving can be achieved with a VAV system. If for some climate zones, a VAV system can achieve close to 50\% energy savings, the VAV system may be a better choice than the hydronic radiant system in terms of initial cost. The improved VAV system incorporates the following energy efficiency measures:

- Premium HVAC equipment efficiency. Both the DX cooling efficiency and the fan motor efficiency are improved. Their premium efficiency values are shown, respectively, in Tables 4.11 and 4.12.

- Expanded use of air economizer. In the improved VAV system, the use of air economizer is expanded to cover climate zones 1A, 2A, 3A and 4A, where air economizers are not required by 90.12004. Economizers controlled by differential enthalpy are used in these hot or warm humid zones (1A, 2A, 3A and 4A) to avoid introducing unwanted moisture into the space while differential dry-bulb temperature based air economizers are used in all other climate zones.

- Motorized outdoor air damper control. The rationale of this measure was explained in Section 4.4. In the VAV system, motorized outdoor air damper control is modeled in EnergyPlus by matching the minimum outdoor air schedule to the occupancy schedule: 1 for occupied hours and 0 for unoccupied hours.

- Demand-controlled ventilation. This measure and its modeling strategy were explained in Section 4.4.

- Energy recovery ventilation (ERV). In the improved VAV system, a rotary energy recovery ventilator is added in the front of each air handling unit. Table 4.11 shows the rated performance of the energy recovery ventilators. The temperature of each energy recovery ventilator's outlet air is controlled by specifying a predefined temperature setpoint. This setpoint has a large impact on the amount of energy saving, and it is set at $45^{\circ} \mathrm{F}\left(7^{\circ} \mathrm{C}\right)$ based on a limited number of parametric runs. 
- Indirect evaporative cooling. Evaporative cooling offers a cost effective solution to reduce mechanical cooling in climate zones with hot/warm and dry weather. There are two types of evaporative cooling techniques: direct and indirect. Although EnergyPlus version3.0 has a number of models for both evaporative cooling techniques, only one indirect evaporative cooling model supports the primary air outlet temperature control to avoid overcooling. Therefore, an indirect evaporative cooler is added to each air system for climate zones 2B, 3B, 4B and 5B. The evaporative cooler is located between the outdoor air mixing box and the cooling coil in the air handling unit. It was simulated with the following technical parameters: a maximum wet-bulb effectiveness of 0.7 ; a secondary fan flow rate of $1695 \mathrm{cfm}\left(0.8 \mathrm{~m}^{3} / \mathrm{s}\right)$; a secondary fan efficiency of $70 \%$; a pressure drop of 0.8 in w.c. (200 Pa) for the primary air, and a secondary fan delta pressure of 1 in w.c. (250 Pa).

- Supply air temperature reset. In the baseline, the primary supply air temperature is controlled at a fixed value of $55^{\circ} \mathrm{F}\left(12.8^{\circ} \mathrm{C}\right)$. Because multi-zone VAV systems are used for the medium office building prototype, reheating cooled air occurs when simultaneous heating and cooling loads exist in different thermal zones. Raising the primary supply air temperature when the system is not at peak cooling demand is an effective measure to reduce the energy consumption for reheating cooled air. Therefore, in the improved VAV system, the primary supply air temperature is reset according to the cooling demand of the warmest zone for each air system. Generally, increasing the primary supply air temperature involves a trade-off between decreased terminal reheating energy and increased fan energy. Therefore, the overall energy savings may vary with the maximum allowed supply reset temperature. Based on a number of trial runs, we found that $61^{\circ} \mathrm{F}\left(16^{\circ} \mathrm{C}\right)$ as the maximum supply reset temperature works well for most cases. This measure was applied to all climate zones except 1A, 2A, 3A and 4A, where humidity control might be an issue from increasing the supply air temperature.

- Revised damper heating action. In the baseline, the damper is maintained at the minimum air flow rate (30\% of the maximum for most zones) when the zone temperature is in deadband and when zone heating is required. In contrast, a revised damper heating action measure is used in the improved VAV system. This measure comes from Addendum H to ASHRAE Standard 90.1-2007 and it involves two essential changes. First, the minimum fraction of air is reduced from $30 \%$ to $20 \%$ when the zone temperature is in deadband. Second, the damper position can open up to $50 \%$ to meet the heating load. Thus, the reduced air flow in deadband saves fan energy and cooling energy. The revised terminal damper control is applied only to the east- and west-oriented perimeter zones on the above-ground floors. This is because reducing minimum terminal damper positions would cause insufficient ventilation for those zones with relatively small cooling load.

\subsection{Service Water Heating}

Because service water heating usually consumes less than $5 \%$ of total onsite energy use for office buildings (CBECS 2003), energy savings for this category are not emphasized. The only measure considered is to improve the thermal efficiency $\left(E_{t}\right)$ from $80 \%$ in the baseline to $95 \%$ in the advanced cases for the gas-fired storage water heater. This increased efficiency can be achieved with high efficiency condensing water heaters. This recommendation is based on a design with restrooms and other domestic hot water uses such as breakroom sinks and dishwashers being located near the core so relatively short pipe runs can be achieved, minimizing circulation losses. A single core water heating system also reduces storage losses. If there are peripheral service hot water uses, these may be more efficiently served with on-demand water heaters. 


\subsection{Cost-Effectiveness Analysis}

Cost of energy measures is as relevant as savings. Based on feedback received from DOE, as well as users and promoters of previous AEDG reports, there is a strong interest in having some sense of the additional costs necessary to meet recommended energy performance levels. Most of the input was focused on the need to have a sense for the additional construction costs rather than the actual costeffectiveness. The cost data provided in this report intends to represent a reasonable estimate of the incremental costs for an energy efficient medium office building based on the prototype used in the energy simulations. This analysis uses incremental costs as the basis of comparison to help offset some of the biases in cost data, when the cost data is deemed to be either routinely high or routinely low. For example, cost data from R.S. Means is generally considered to be a bit high in absolute value by consulting engineers who frequently use R.S. Means data as a method of quick estimation for budgeting purposes. Using differences between the baseline and the advanced energy features costs (i.e., incremental costs), whether absolutely high or low, may result in costs which are more representative of the actual incremental cost seen in the industry.

The recommended energy efficiency measures with radiant systems are estimated to have an average payback of 7.4 years. The alternative package with VAV systems has an average payback of 4.6 years. Lighting costs lower for the energy measure packages than for the baseline because of reduced wattage and number of fixtures partially offset by more expensive per watt equipment. The HVAC system cost estimates take into account significantly lowered system cooling capacity. Actual project costs will vary, but the cost-effectiveness analysis does suggest that 50\% energy savings can be achieved for new medium offices with a reasonable added cost.

\subsection{Basis for Incremental Energy Savings Measure Costs}

The costs for various energy savings measures are developed as incremental costs based on the difference between the costs for the baseline measure and the costs for the energy savings measure. The incremental costs may be based on a per unit cost, such as costs per square foot of wall area, or a per building cost, such as the cost of a single air conditioning unit that serves an entire building or section of a building. This approach requires that for each measure, both the baseline cost and the energy savings measure cost must be developed or data must be explicitly available on incremental costs.

The medium office prototype building described in Section 3.0 was used as the basis to develop the cost data. Costs were developed for each of the efficiency measures used in the building, and then the measure costs were summed to get the overall cost premium for the building prototype. The advanced costs for lighting and HVAC include added design, calibration, and commissioning costs. Costeffectiveness information is provided for both the radiant system with DOAS case that achieves $50 \%$ savings and the alternative VAV system case.

Table 5.1 summarizes the basis for estimating both the baseline and energy savings costs for the radiant system cases and Table 5.2 provides the same information for the VAV system case just for the different HVAC systems, as other components are the same as for the radiant system case. 
Table 5.1. Cost Calculation Method Summary - Radiant System

\begin{tabular}{|c|c|c|}
\hline Component & Cost Equation & Source \\
\hline Roof Insulation & $\begin{array}{l}\text { Cost }=\text { Area of roof } x \text { incremental } \$ / \mathrm{ft}^{2} \\
\left(\$ / \mathrm{m}^{2}\right) \text { of higher insulation value }\end{array}$ & RS Means 2009 \\
\hline Exterior Wall Insulation & $\begin{array}{l}\text { Cost }=\text { Area of exterior wall } x \text { incremental } \\
\$ / \mathrm{ft}^{2}\left(\$ / \mathrm{m}^{2}\right) \text { of higher insulation value }\end{array}$ & RS Means 2009 \\
\hline Slab Insulation & $\begin{array}{l}\text { Cost = Advanced case slab-on-grade } \\
\text { perimeter insulation area plus underfloor } \\
\text { insulation area for the interior floor radiant } \\
\text { systems x corresponding cost } / \mathrm{ft}^{2} \text { minus the } \\
\text { baseline slab insulation area } \mathrm{x} \text { cost per } \\
\text { square foot. }\end{array}$ & RS Means 2009 \\
\hline Cool Roof & Roof area $x \$ / \mathrm{ft}^{2}\left(\$ / \mathrm{m}^{2}\right)$ & Jiang W et. al. 2008 \\
\hline Sunshade Overhang & $\begin{array}{l}\text { Overhang shading structure linear feet }(\mathrm{m}) \mathrm{x} \\
\text { cost per linear foot (m) (no overhang in } \\
\text { baseline) }\end{array}$ & $\begin{array}{l}\text { RS Means } 2009 \text { - For metal building , } \\
\text { adjusted for higher end building }\end{array}$ \\
\hline Windows \& doors & $\begin{array}{l}\text { Cost }=\text { Area of windows } x \text { incremental } \$ / \mathrm{ft}^{2} \\
\left(\$ / \mathrm{m}^{2}\right) \text { of window type based on overall u- } \\
\text { value }\end{array}$ & $\begin{array}{l}\text { 90.1 Envelope Committee supporting } \\
\text { fenestration data in progress }\end{array}$ \\
\hline Interior Lighting & $\begin{array}{l}\text { Cost = Incremental cost of lighting, controls } \\
\text { and engineering }\end{array}$ & Seattle Lighting Lab - Michael Lane \\
\hline Exterior Lighting & Cost $=$ Incremental cost of exterior lighting & Seattle Lighting Lab - Michael Lane \\
\hline Plug Loads & $\begin{array}{l}\text { Incremental cost of more efficient plug-in } \\
\text { equipment and added controls including } \\
\text { software }\end{array}$ & on-line sources primarily EnergyStar.gov \\
\hline $\begin{array}{l}\text { Packaged VAV vs. } \\
\text { Radiant Systems } \\
\text { including chiller and } \\
\text { boiler }\end{array}$ & $\begin{array}{l}\text { Cost }=\text { Cost of advanced system minus cost } \\
\text { of baseline system. Costs based on cost per } \\
\text { ton }(\mathrm{W}), \mathrm{cfm}\left(\mathrm{m}^{3} / \mathrm{s}\right) \text { or square foot }\left(\mathrm{m}^{2}\right) \text { as } \\
\text { appropriate }\end{array}$ & $\begin{array}{l}\text { RS Means } 2009 \\
\text { Radiant surfaces }^{(a)}\end{array}$ \\
\hline Dedicated Outdoor Air & $\begin{array}{l}\text { Cost }=\text { Added cost, } \$ . \text { No equivalent } \\
\text { system in baseline }\end{array}$ & RS Means 2009 \\
\hline \multicolumn{3}{|c|}{$\begin{array}{l}\text { (a) Finding consistent cost data on radiant systems is difficult. Online sources for commercial radiant system cost } \\
\text { were not found. Mean's Guide did not provide a system cost. Three sources are provided. PAE Engineering } \\
\text { Consulting indicates radiant system costs are not substantially higher that for VAV (experience primarily with } \\
\text { radiant ceiling systems). Glumac (engineering consulting firm) estimates a } \$ 2.50-\$ 4.00 / \mathrm{ft}^{2}\left(\$ 26.91-43.06 / \mathrm{m}^{2}\right) \\
\text { added cost for the radiant surfaces, in particular for radiant ceiling systems. SSHC Inc, a vendor and design } \\
\text { firm estimates a total system cost of } \$ 10-\$ 12 / \mathrm{ft}^{2}\left(\$ 108-129 / \mathrm{m}^{2}\right) \text { for hydronic radiant systems and shares that } \\
\text { floor systems are similar in cost to ceiling systems. A value for the radiant surfaces was entered as } \$ 3.50 / \mathrm{ft}^{2} \\
\left(\$ 37.68 / \mathrm{m}^{2}\right) \text { plus added cost for insulation of about } \$ 0.80 / \mathrm{ft}^{2}\left(\$ 8.61 / \mathrm{m}^{2}\right) \text {. The total average premium for the } \\
\text { radiant system is } \$ 4.08 / \mathrm{ft}^{2}\left(\$ 43.92 / \mathrm{m}^{2}\right) \text { over the VAV costs which average } \$ 5.23\left(\$ 56.30 / \mathrm{m}^{2}\right) \text { per square foot. } \\
\text { The total radiant system including plant cost averages } \$ 9.31 / \mathrm{ft}^{2}\left(\$ 100.22 / \mathrm{m}^{2}\right) \text {. This radiant system value is } \\
\text { lower than the } \$ 10-12 / \mathrm{ft}^{2}\left(\$ 108-129 / \mathrm{m}^{2}\right) \text { because there is a } 29 \% \text { average cooling load reduction from other } \\
\text { efficiency measures for the advanced case relative to the code baseline, and the } \$ 10-\$ 12 / \mathrm{ft}^{2}\left(\$ 108-129 / \mathrm{m}^{2}\right) \text { was } \\
\text { described as a complete all in cost including ancillary costs such as for the cost of the space for the plant. The } \\
\text { VAV estimate also does not include such ancillary costs, so the value for the radiant system in comparison is } \\
\text { believed to be reasonable. This premium is } 78 \% \text { on average over the VAV system and is a compromise } \\
\text { between views that the radiant system cost is similar to the VAV cost to as much as twice the cost. }\end{array}$} \\
\hline
\end{tabular}


Table 5.2. Cost Calculation Method Summary - VAV System

(HVAC costs only, other incremental costs same as for Radiant with DOAS case)

\begin{tabular}{lll}
\hline \multicolumn{1}{c}{ Component } & \multicolumn{1}{c}{ Cost Equation } & \multicolumn{1}{c}{ Source } \\
\hline Packaged VAV vs. High & Cost $=$ Cost of advanced system minus cost of & RS Means 2009 \\
Efficiency Packaged VAV with & baseline system. Costs based on cost per ton & \\
added controls and climate zone & $(\mathrm{W}), \mathrm{cfm}\left(\mathrm{m}^{3} / \mathrm{s}\right)$ or square foot $\left(\mathrm{m}^{2}\right)$ as \\
specific system additions & $\begin{array}{l}\text { appropriate Rough estimate for controls based on } \\
\text { assumed number of sensors, control points }\end{array}$ & \\
& & \\
\hline
\end{tabular}

\subsection{Comparison of Incremental Costs to Baseline Costs for Construction}

Incremental costs were calculated using the methodology described in Section 5.1. Table 5.3 covers the incremental costs for the radiant system alternative, and Table 5.4 covers the incremental costs for the VAV system alternative. Values shown in red indicate that the costs for the advanced case are lower than for the baseline. For lighting, this is due to less lighting equipment for the advanced case. For HVAC in the VAV case, this is primarily the result of large reductions in cooling capacity for the advanced case, except for some climates where the cooling capacity was reduced significantly less than for the climate zones that have a cost reduction.

Another item that needs to be addressed is the baseline costs for construction of typical medium offices. Armed with this information, designers and owners can quickly evaluate the estimated cost premiums for meeting the recommendations of the TSD. Within the design and construction community, the quick evaluation of cost premiums versus the expected cost per square foot (square meter) estimates may serves as a surrogate for cost-effectiveness in many cases.

For example, the 2009 version of R.S. Means Construction Cost Data (R.S. Means 2009) indicates that for offices, the median unit construction cost is $\$ 120 / \mathrm{ft}^{2}\left(\$ 1290 / \mathrm{m}^{2}\right)$ with a lower quartile value of $\$ 93 / \mathrm{ft}^{2}\left(\$ 1000 / \mathrm{m}^{2}\right)$ and an upper quartile value of $\$ 155.00 / \mathrm{ft}^{2}\left(\$ 1670 / \mathrm{m}^{2}\right)$. These values are for $1-4-$ story offices. The values are very similar for the next size category, mid-rise 5-10-story office buildings. The median unit construction cost is then adjusted based on a multiplier for the ratio of the prototype building size to the typical Means building size, yielding an adjusted median unit construction cost of $\$ 111.60 / \mathrm{ft}^{2}$ $\left(\$ 1200 / \mathrm{m}^{2}\right)$. Initial construction costs tend to be lower for larger buildings mainly because of economies of scale and the decreased contribution of the exterior walls. Median unit construction costs are also adjusted for Means city cost indexes. Cost premiums are developed using the incremental costs for the energy savings measures in each climate zone. Presumably cost premiums of a few percent of the average construction costs might be deemed to be in the cost effective range, while those in higher ranges of percentage might not.

To address the needs of this segment of the industry the total incremental costs developed in Tables 5.3 and 5.4 are compared to the median baseline construction costs to help evaluate the surrogate cost-effectiveness of the recommendations for each of the climate zones. Tables 5.5 and 5.6 provide this comparison for the radiant system and VAV system alternatives, respectively. 
Table 5.3. Incremental Cost - Radiant System

\begin{tabular}{|c|c|c|c|c|c|c|c|c|c|c|c|c|c|c|c|c|}
\hline Component & $\begin{array}{c}1 \mathrm{~A} \\
\text { Miami }\end{array}$ & $\begin{array}{c}2 \mathrm{~A} \\
\text { Houston }\end{array}$ & $\begin{array}{c}\text { 2B } \\
\text { Phoenix }\end{array}$ & $\begin{array}{c}3 \mathrm{~A} \\
\text { Atlanta }\end{array}$ & $\begin{array}{c}\text { 3B-CA } \\
\text { Los Angeles }\end{array}$ & $\begin{array}{c}\text { 3B-other } \\
\text { Las Vegas }\end{array}$ & $\begin{array}{c}3 \mathrm{C} \\
\text { San Francisco }\end{array}$ & $\begin{array}{c}4 \mathrm{~A} \\
\text { Baltimore }\end{array}$ & $\begin{array}{c}4 \mathrm{~B} \\
\text { Albequerque }\end{array}$ & $\begin{array}{c}4 C \\
\text { Seattle }\end{array}$ & $\begin{array}{c}5 \mathrm{~A} \\
\text { Chicago }\end{array}$ & $\begin{array}{c}5 \mathrm{~B} \\
\text { Denver }\end{array}$ & $\begin{array}{c}6 \mathrm{~A} \\
\text { Minneapolis }\end{array}$ & $\begin{array}{c}6 \mathrm{~B} \\
\text { Helena }\end{array}$ & $\begin{array}{c}7 \\
\text { Duluth }\end{array}$ & $\begin{array}{c}8 \\
\text { Fairbanks }\end{array}$ \\
\hline Roof Insulation & $\$ 7,155$ & $\$ 15,919$ & $\$ 15,919$ & $\$ 15,919$ & $\$ 15,919$ & $\$ 15,919$ & $\$ 15,919$ & $\$ 23,074$ & $\$ 23,074$ & $\$ 23,074$ & $\$ 23,074$ & $\$ 23,074$ & $\$ 23,074$ & $\$ 23,074$ & $\$ 30,229$ & $\$ 23,074$ \\
\hline Ex terior Wall Insulation & $\$ 28,428$ & $\$ 28,428$ & $\$ 28,428$ & $\$ 28,428$ & $\$ 28,428$ & $\$ 28,428$ & $\$ 28,428$ & $\$ 28,428$ & $\$ 28,428$ & $\$ 28,428$ & $\$ 25,987$ & $\$ 25,987$ & $\$ 30,839$ & $\$ 30,839$ & $\$ 19,407$ & $\$ 19,407$ \\
\hline Cool Roof & $\$ 9,839$ & $\$ 9,839$ & $\$ 9,839$ & $\$ 9,839$ & $\$ 9,839$ & $\$ 9,839$ & $\$ 9,839$ & & & & & & & & & \\
\hline Sunshade Overhang & $\$ 8,925$ & $\$ 8,925$ & $\$ 8,925$ & $\$ 8,925$ & $\$ 8,925$ & $\$ 8,925$ & $\$ 8,925$ & $\$ 8,925$ & $\$ 8,925$ & $\$ 8,925$ & $\$ 8,925$ & $\$ 8,925$ & & & & \\
\hline Windows \& doors & $\$ 21,554$ & $\$ 21,554$ & $\$ 21,554$ & $\$ 21,745$ & $\$ 21,745$ & $\$ 21,745$ & $\$ 21,745$ & $\$ 4,797$ & $\$ 4,797$ & $\$ 4,797$ & $\$ 4,797$ & $\$ 4,797$ & $\$ 7,841$ & $\$ 7,841$ & $\$ 28,787$ & $\$ 25,296$ \\
\hline Interior Lighting & \multicolumn{16}{|c|}{$(\$ 17,732)$} \\
\hline Exterior Lighting & \multicolumn{16}{|c|}{$(\$ 3,900)$} \\
\hline Plug Loads & \multicolumn{16}{|c|}{$\$ 86,642$} \\
\hline $\begin{array}{l}\text { Packaged VAV vs. Radiant } \\
\text { sy stem with chiller and } \\
\text { boiler }\end{array}$ & $\$ 148,644$ & $\$ 167,802$ & $\$ 169,121$ & $\$ 192,238$ & $\$ 231,329$ & $\$ 186,586$ & $\$ 206,280$ & $\$ 192,449$ & $\$ 178,123$ & $\$ 218,755$ & $\$ 201,361$ & $\$ 183,269$ & $\$ 186,729$ & $\$ 186,060$ & $\$ 151,569$ & $\$ 177,693$ \\
\hline Dedicated Outside Air & \multicolumn{16}{|c|}{$\$ 34,424$} \\
\hline Service Water Heater & \multicolumn{16}{|c|}{$\$ 560$} \\
\hline Sub-total & $\$ 324,537$ & $\$ 352,460$ & $\$ 353,780$ & $\$ 377,088$ & $\$ 416,179$ & $\$ 371,436$ & $\$ 391,130$ & $\$ 357,667$ & $\$ 343,340$ & $\$ 383,972$ & $\$ 364,137$ & $\$ 346,046$ & $\$ 348,476$ & $\$ 347,808$ & $\$ 329,986$ & $\$ 345,463$ \\
\hline $\begin{array}{l}\text { Location Cost Index, \% } \\
\text { (RS Means 2009) }\end{array}$ & $90 \%$ & $88 \%$ & $89 \%$ & $90 \%$ & $108 \%$ & $106 \%$ & $124 \%$ & $93 \%$ & $90 \%$ & $104 \%$ & $115 \%$ & $95 \%$ & $110 \%$ & $90 \%$ & $102 \%$ & $121 \%$ \\
\hline
\end{tabular}


Table 5.4. Incremental Cost - VAV System

\begin{tabular}{|c|c|c|c|c|c|c|c|c|c|c|c|c|c|c|c|c|}
\hline Component & $\begin{array}{c}1 \mathrm{~A} \\
\text { Miami }\end{array}$ & $\begin{array}{c}2 \mathrm{~A} \\
\text { Houston }\end{array}$ & $\begin{array}{c}2 \mathrm{~B} \\
\text { Phoenix }\end{array}$ & $\begin{array}{c}3 \mathrm{~A} \\
\text { Atlanta }\end{array}$ & $\begin{array}{c}\text { 3B-CA } \\
\text { Los Angeles }\end{array}$ & $\begin{array}{c}\text { 3B-other } \\
\text { Las Vegas }\end{array}$ & $\begin{array}{c}3 \mathrm{C} \\
\text { San Francisco }\end{array}$ & $\begin{array}{c}4 \mathrm{~A} \\
\text { Baltimore }\end{array}$ & $\begin{array}{c}4 \mathrm{~B} \\
\text { Albequerque }\end{array}$ & $\begin{array}{c}4 C \\
\text { Seattle }\end{array}$ & $\begin{array}{c}5 \mathrm{~A} \\
\text { Chicago }\end{array}$ & $\begin{array}{c}5 \mathrm{~B} \\
\text { Denver }\end{array}$ & $\begin{array}{c}6 \mathrm{~A} \\
\text { Minneapolis }\end{array}$ & $\begin{array}{l}6 \mathrm{~B} \\
\text { Helena }\end{array}$ & $\begin{array}{c}7 \\
\text { Duluth }\end{array}$ & $\begin{array}{c}8 \\
\text { Fairbanks }\end{array}$ \\
\hline Roof Insulation & $\$ 7,155$ & $\$ 15,919$ & $\$ 15,919$ & $\$ 15,919$ & $\$ 15,919$ & $\$ 15,919$ & $\$ 15,919$ & $\$ 23,074$ & $\$ 23,074$ & $\$ 23,074$ & $\$ 23,074$ & $\$ 23,074$ & $\$ 23,074$ & $\$ 23,074$ & $\$ 30,229$ & $\$ 23,074$ \\
\hline Ex terior Wall Insulation & $\$ 28,428$ & $\$ 28,428$ & $\$ 28,428$ & $\$ 28,428$ & $\$ 28,428$ & $\$ 28,428$ & $\$ 28,428$ & $\$ 28,428$ & $\$ 28,428$ & $\$ 28,428$ & $\$ 25,987$ & $\$ 25,987$ & $\$ 30,839$ & $\$ 30,839$ & $\$ 19,407$ & $\$ 19,407$ \\
\hline Cool Roof & $\$ 9,839$ & $\$ 9,839$ & $\$ 9,839$ & $\$ 9,839$ & $\$ 9,839$ & $\$ 9,839$ & $\$ 9,839$ & & & & & & & & & \\
\hline Sunshade Overhang & $\$ 8,925$ & $\$ 8,925$ & $\$ 8,925$ & $\$ 8,925$ & $\$ 8,925$ & $\$ 8,925$ & $\$ 8,925$ & $\$ 8,925$ & $\$ 8,925$ & $\$ 8,925$ & $\$ 8,925$ & $\$ 8,925$ & & & & \\
\hline Windows \& doors & $\$ 21,554$ & $\$ 21,554$ & $\$ 21,554$ & $\$ 21,745$ & $\$ 21,745$ & $\$ 21,745$ & $\$ 21,745$ & $\$ 4,797$ & $\$ 4,797$ & $\$ 4,797$ & $\$ 4,797$ & $\$ 4,797$ & $\$ 7,841$ & $\$ 7,841$ & $\$ 28,787$ & $\$ 25,296$ \\
\hline Interior Lighting & \multicolumn{16}{|c|}{$(\$ 17,732)$} \\
\hline Exterior Lighting & \multicolumn{16}{|c|}{$(\$ 3,900)$} \\
\hline Plug Loads & \multicolumn{16}{|c|}{$\$ 86,642$} \\
\hline $\begin{array}{l}\text { Packaged VAV vs. Advanced } \\
\text { Packaged VAV includes } \\
\text { DOAS, ev aporativ e cooling, } \\
\text { economizer if applicable to } \\
\text { climate zone }\end{array}$ & $\$ 52,523$ & $\$ 62,942$ & $\$ 81,907$ & $\$ 84,507$ & $\$ 36,322$ & $\$ 18,044$ & $\$ 17,605$ & $\$ 80,578$ & $\$ 40,629$ & $\$ 29,480$ & $\$ 37,833$ & $\$ 50,932$ & $\$ 78,655$ & $\$ 14,093$ & $\$ 16,873$ & $\$ 53,002$ \\
\hline Service Water Heater & \multicolumn{16}{|c|}{$\$ 560$} \\
\hline Sub-total & $\$ 193,993$ & $\$ 213,177$ & $\$ 232,141$ & $\$ 234,933$ & $\$ 186,748$ & $\$ 168,470$ & $\$ 168,031$ & $\$ 211,372$ & $\$ 171,423$ & $\$ 160,274$ & $\$ 166,185$ & $\$ 179,285$ & $\$ 205,979$ & $\$ 141,417$ & $\$ 160,866$ & $\$ 186,348$ \\
\hline $\begin{array}{l}\text { Location Cost Index, \% } \\
\text { (RS Means 2009) }\end{array}$ & $90 \%$ & $88 \%$ & $89 \%$ & $90 \%$ & $108 \%$ & $106 \%$ & $124 \%$ & $93 \%$ & $90 \%$ & $104 \%$ & $115 \%$ & $95 \%$ & $110 \%$ & $90 \%$ & $102 \%$ & $121 \%$ \\
\hline TOTAL (location adjusted) & $\$ 175,176$ & $\$ 188,235$ & $\$ 206,606$ & $\$ 211,909$ & $\$ 202,249$ & $\$ 178,072$ & $\$ 208,022$ & $\$ 196,787$ & $\$ 153,938$ & $\$ 166,525$ & $\$ 190,947$ & $\$ 170,321$ & $\$ 226,165$ & $\$ 127,134$ & $\$ 164,727$ & $\$ 226,041$ \\
\hline
\end{tabular}


Table 5.5. Unit Cost Increase - Radiant System

\begin{tabular}{|c|c|c|c|c|c|c|c|c|c|}
\hline $\begin{array}{l}\text { Climate } \\
\text { Zone }\end{array}$ & City & $\begin{array}{c}\text { Incremental } \\
\text { Cost }\end{array}$ & $\begin{array}{c}\text { Unit Cost } \\
\text { Increase, } \\
\$ / \mathbf{f t}^{2}\end{array}$ & $\$ / m^{2}$ & $\begin{array}{c}\text { Location } \\
\text { Adjusted } \\
\text { Baseline } \\
\text { Median } \\
\text { Unit Cost, } \\
\$ / \mathbf{f t}^{2}\end{array}$ & $\$ / m^{2}$ & $\begin{array}{c}\text { Advanced } \\
\text { Unit } \\
\text { Construction } \\
\text { Cost, } \$ / \mathbf{f t}^{2}\end{array}$ & $\$ / m^{2}$ & $\begin{array}{l}\text { Percentage of } \\
\text { Unit Cost } \\
\text { Increase } \\
\text { Over Unit } \\
\text { Median } \\
\text { Baseline }\end{array}$ \\
\hline $1 \mathrm{~A}$ & Miami & $\$ 293,057$ & $\$ 5.47$ & $\$ 58.86$ & $\$ 100.77$ & $\$ 1,084.84$ & $\$ 106.24$ & $\$ 1,143.70$ & $5.4 \%$ \\
\hline $3 \mathrm{~A}$ & Atlanta & $\$ 340,133$ & $\$ 6.35$ & $\$ 68.31$ & $\$ 100.66$ & $\$ 1,083.64$ & $\$ 107.01$ & $\$ 1,151.95$ & $6.3 \%$ \\
\hline $3 B$ & Los Angeles & $\$ 450,722$ & $\$ 8.41$ & $\$ 90.52$ & $\$ 120.86$ & $\$ 1,301.09$ & $\$ 129.27$ & $\$ 1,391.61$ & $7.0 \%$ \\
\hline 3B & Las Vegas & $\$ 392,607$ & $\$ 7.32$ & $\$ 78.85$ & $\$ 117.96$ & $\$ 1,269.85$ & $\$ 125.29$ & $\$ 1,348.70$ & $6.2 \%$ \\
\hline $3 C$ & San Fran. & $\$ 484,219$ & $\$ 9.03$ & $\$ 97.25$ & $\$ 138.16$ & $\$ 1,487.30$ & $\$ 147.19$ & $\$ 1,584.55$ & $6.5 \%$ \\
\hline $5 \mathrm{~A}$ & Chicago & $\$ 418,394$ & $\$ 7.81$ & $\$ 84.03$ & $\$ 128.23$ & $\$ 1,380.38$ & $\$ 136.03$ & $\$ 1,464.41$ & $6.1 \%$ \\
\hline $5 B$ & Denver & $\$ 328,743$ & $\$ 6.13$ & $\$ 66.02$ & $\$ 106.02$ & $\$ 1,141.31$ & $\$ 112.15$ & $\$ 1,207.33$ & $5.8 \%$ \\
\hline $6 \mathrm{~A}$ & Minneapolis & $\$ 382,627$ & $\$ 7.14$ & $\$ 76.85$ & $\$ 122.54$ & $\$ 1,319.11$ & $\$ 129.68$ & $\$ 1,395.96$ & $5.8 \%$ \\
\hline $6 \mathrm{~B}$ & Helena & $\$ 312,679$ & $\$ 5.83$ & $\$ 62.80$ & $\$ 100.33$ & $\$ 1,080.04$ & $\$ 106.16$ & $\$ 1,142.83$ & $5.8 \%$ \\
\hline 7 & Duluth & $\$ 337,906$ & $\$ 6.30$ & $\$ 67.86$ & $\$ 114.28$ & $\$ 1,230.21$ & $\$ 120.58$ & $\$ 1,298.07$ & $5.5 \%$ \\
\hline 8 & Fairbanks & $\$ 419,047$ & $\$ 7.82$ & $\$ 84.16$ & $\$ 135.37$ & $\$ 1,457.27$ & $\$ 143.19$ & $\$ 1,541.43$ & $5.8 \%$ \\
\hline
\end{tabular}


Table 5.6. Unit Cost Increase - VAV System

\begin{tabular}{|c|c|c|c|c|c|c|c|c|c|}
\hline $\begin{array}{l}\text { Climate } \\
\text { Zone }\end{array}$ & City & $\begin{array}{c}\text { Incremental } \\
\text { Cost }\end{array}$ & $\begin{array}{c}\text { Unit Cost } \\
\text { Increase, } \\
\$ \$ \mathbf{f t}^{2}\end{array}$ & $\$ / m^{2}$ & $\begin{array}{c}\text { Location } \\
\text { Adjusted } \\
\text { Baseline } \\
\text { Median } \\
\text { Unit Cost, } \\
\$ / \text { ft }^{2}\end{array}$ & $\$ / m^{2}$ & $\begin{array}{c}\text { Advanced } \\
\text { Unit } \\
\text { Construction } \\
\text { Cost, } \\
\$ / f^{2}{ }^{2}\end{array}$ & $\$ / m^{2}$ & $\begin{array}{c}\text { Percentage } \\
\text { of Unit } \\
\text { Cost } \\
\text { Increase } \\
\text { Over Unit } \\
\text { Median } \\
\text { Baseline } \\
\end{array}$ \\
\hline $1 \mathrm{~A}$ & Miami & $\$ 175,176$ & $\$ 3.27$ & $\$ 35.18$ & $\$ 100.77$ & $\$ 1,084.84$ & $\$ 104.04$ & $\$ 1,120.02$ & $3.2 \%$ \\
\hline $2 \mathrm{~A}$ & Houston & $\$ 188,235$ & $\$ 3.51$ & $\$ 37.81$ & $\$ 98.54$ & $\$ 1,060.81$ & $\$ 102.05$ & $\$ 1,098.62$ & $3.6 \%$ \\
\hline $2 B$ & Phoenix & $\$ 206,606$ & $\$ 3.85$ & $\$ 41.49$ & $\$ 99.32$ & $\$ 1,069.22$ & $\$ 103.18$ & $\$ 1,110.72$ & $3.9 \%$ \\
\hline $3 \mathrm{~A}$ & Atlanta & $\$ 211,909$ & $\$ 3.95$ & $\$ 42.56$ & $\$ 100.66$ & $\$ 1,083.64$ & $\$ 104.62$ & $\$ 1,126.20$ & $3.9 \%$ \\
\hline 3B & Los Angeles & $\$ 202,249$ & $\$ 3.77$ & $\$ 40.62$ & $\$ 120.86$ & $\$ 1,301.09$ & $\$ 124.64$ & $\$ 1,341.71$ & $3.1 \%$ \\
\hline 3B & Las Vegas & $\$ 178,072$ & $\$ 3.32$ & $\$ 35.76$ & $\$ 117.96$ & $\$ 1,269.85$ & $\$ 121.28$ & $\$ 1,305.62$ & $2.8 \%$ \\
\hline $3 \mathrm{C}$ & San Fran. & $\$ 208,022$ & $\$ 3.88$ & $\$ 41.78$ & $\$ 138.16$ & $\$ 1,487.30$ & $\$ 142.04$ & $\$ 1,529.08$ & $2.8 \%$ \\
\hline $4 \mathrm{~A}$ & Baltimore & $\$ 196,787$ & $\$ 3.67$ & $\$ 39.52$ & $\$ 103.90$ & $\$ 1,118.48$ & $\$ 107.57$ & $\$ 1,158.00$ & $3.5 \%$ \\
\hline $4 \mathrm{~B}$ & Albuquerque & $\$ 153,938$ & $\$ 2.87$ & $\$ 30.92$ & $\$ 100.22$ & $\$ 1,078.83$ & $\$ 103.09$ & $\$ 1,109.75$ & $2.9 \%$ \\
\hline $4 \mathrm{C}$ & Seattle & $\$ 166,525$ & $\$ 3.11$ & $\$ 33.44$ & $\$ 115.95$ & $\$ 1,248.23$ & $\$ 119.06$ & $\$ 1,281.67$ & $2.7 \%$ \\
\hline $5 \mathrm{~A}$ & Chicago & $\$ 190,947$ & $\$ 3.56$ & $\$ 38.35$ & $\$ 128.23$ & $\$ 1,380.38$ & $\$ 131.79$ & $\$ 1,418.73$ & $2.8 \%$ \\
\hline $5 B$ & Denver & $\$ 170,321$ & $\$ 3.18$ & $\$ 34.21$ & $\$ 106.02$ & $\$ 1,141.31$ & $\$ 109.20$ & $\$ 1,175.51$ & $3.0 \%$ \\
\hline $6 \mathrm{~A}$ & Minneapolis & $\$ 226,165$ & $\$ 4.22$ & $\$ 45.42$ & $\$ 122.54$ & $\$ 1,319.11$ & $\$ 126.76$ & $\$ 1,364.53$ & $3.4 \%$ \\
\hline $6 \mathrm{~B}$ & Helena & $\$ 127,134$ & $\$ 2.37$ & $\$ 25.53$ & $\$ 100.33$ & $\$ 1,080.04$ & $\$ 102.70$ & $\$ 1,105.57$ & $2.4 \%$ \\
\hline 7 & Duluth & $\$ 164,727$ & $\$ 3.07$ & $\$ 33.08$ & $\$ 114.28$ & $\$ 1,230.21$ & $\$ 117.35$ & $\$ 1,263.29$ & $2.7 \%$ \\
\hline 8 & Fairbanks & $\$ 226,041$ & $\$ 4.22$ & $\$ 45.40$ & $\$ 135.37$ & $\$ 1,457.27$ & $\$ 139.59$ & $\$ 1,502.66$ & $3.1 \%$ \\
\hline
\end{tabular}




\subsection{Cost-Effectiveness Calculations}

Cost- effectiveness can be shown most directly by looking at the simple payback period for the energy savings measures recommended in the report. For the radiant systems case, Table 5.7 shows simple payback values vary from 5.6 to 11.5 years with an average of 7.4 years. For the VAV systems case, Table 5.8 shows simple payback values vary from 3.3 to 6.2 years with an average of 4.6 years. The largest source of the variability in the paybacks is differences in HVAC system and plant heating and cooling capacity, which varies between climate zones. The variability also results in some cases from step changes in component performance and cost such as insulation R-value in the code baseline that are different than the step changes in the advanced case so that the difference in cost varies between climate zones. The simple payback is calculated for the energy savings measures in aggregate by dividing the total incremental cost of the measures by the energy savings in dollars. Energy savings in dollars is calculated by using the EIA national average natural gas rate of $\$ 1.16 /$ therm $\left(\$ 0.41 / \mathrm{m}^{3}\right)$ and the national average electric rate of $\$ 0.0939 / \mathrm{kWh}$ (EIA 2006). These rates are the same ones being used by the SSPC 90.1 Committee in developing the 2010 version of Standard 90.1.

Table 5.7. Simple Payback Period - Radiant System

\begin{tabular}{|c|c|c|c|c|c|c|}
\hline \multirow{2}{*}{$\begin{array}{l}\text { Climate } \\
\text { Zone }\end{array}$} & \multirow{2}{*}{ City } & \multirow{2}{*}{$\begin{array}{l}\text { Incremental } \\
\text { Cost }\end{array}$} & \multicolumn{3}{|c|}{ Energy Cost Savings } & \multirow{2}{*}{$\begin{array}{c}\text { Simple } \\
\text { Payback } \\
\text { (Years) }\end{array}$} \\
\hline & & & Electricity & $\begin{array}{c}\text { Natural } \\
\text { Gas }\end{array}$ & Total & \\
\hline $1 \mathrm{~A}$ & Miami & $\$ 293,057$ & $\$ 44,451$ & $\$ 50$ & $\$ 44,501$ & 6.6 \\
\hline $2 \mathrm{~A}$ & Houston & $\$ 311,222$ & $\$ 48,583$ & (\$314) & $\$ 48,268$ & 6.4 \\
\hline 2B & Phoenix & $\$ 314,864$ & $\$ 49,067$ & $(\$ 162)$ & $\$ 48,905$ & 6.4 \\
\hline $3 \mathrm{~A}$ & Atlanta & $\$ 340,133$ & $\$ 47,149$ & $(\$ 1,061)$ & $\$ 46,088$ & 7.4 \\
\hline 3B & Los Angeles & $\$ 450,722$ & $\$ 39,045$ & $\$ 1$ & $\$ 39,046$ & 11.5 \\
\hline 3B & Las Vegas & $\$ 392,607$ & $\$ 45,242$ & (\$626) & $\$ 44,616$ & 8.8 \\
\hline $3 \mathrm{C}$ & San Fran. & $\$ 484,219$ & $\$ 44,201$ & (\$528) & $\$ 43,673$ & 11.1 \\
\hline $4 \mathrm{~A}$ & Baltimore & $\$ 332,988$ & $\$ 55,265$ & $(\$ 1,738)$ & $\$ 53,526$ & 6.2 \\
\hline 4B & Albuquerque & $\$ 308,320$ & $\$ 47,129$ & $(\$ 1,295)$ & $\$ 45,834$ & 6.7 \\
\hline 4C & Seattle & $\$ 398,947$ & $\$ 49,323$ & $(\$ 1,219)$ & $\$ 48,104$ & 8.3 \\
\hline $5 \mathrm{~A}$ & Chicago & $\$ 418,394$ & $\$ 55,298$ & $(\$ 2,017)$ & $\$ 53,281$ & 7.9 \\
\hline $5 B$ & Denver & $\$ 328,743$ & $\$ 49,407$ & $(\$ 1,619)$ & $\$ 47,788$ & 6.9 \\
\hline $6 \mathrm{~A}$ & Minneapolis & $\$ 382,627$ & $\$ 57,825$ & $(\$ 1,997)$ & $\$ 55,829$ & 6.9 \\
\hline $6 \mathrm{~B}$ & Helena & $\$ 312,679$ & $\$ 52,948$ & $(\$ 1,726)$ & $\$ 51,222$ & 6.1 \\
\hline 7 & Duluth & $\$ 337,906$ & $\$ 62,353$ & $(\$ 1,718)$ & $\$ 60,634$ & 5.6 \\
\hline 8 & Fairbanks & $\$ 419,047$ & $\$ 66,327$ & $(\$ 414)$ & $\$ 65,913$ & 6.4 \\
\hline
\end{tabular}


Table 5.8. Simple Payback Period - VAV System

\begin{tabular}{|c|c|c|c|c|c|c|}
\hline \multirow{2}{*}{$\begin{array}{l}\text { Climate } \\
\text { Zone }\end{array}$} & \multirow{2}{*}{ City } & \multirow{2}{*}{$\begin{array}{l}\text { Incremental } \\
\text { Cost }\end{array}$} & \multicolumn{3}{|c|}{ Energy Cost Savings } & \multirow{2}{*}{$\begin{array}{c}\text { Simple } \\
\text { Payback } \\
\text { (Years) }\end{array}$} \\
\hline & & & Electricity & Natural Gas & Total & \\
\hline $1 \mathrm{~A}$ & Miami & $\$ 175,176$ & $\$ 38,897$ & $\$ 68$ & $\$ 38,965$ & 4.5 \\
\hline $2 \mathrm{~A}$ & Houston & $\$ 188,235$ & $\$ 39,577$ & $\$ 221$ & $\$ 39,797$ & 4.7 \\
\hline $2 B$ & Phoenix & $\$ 206,606$ & $\$ 45,183$ & $(\$ 21)$ & $\$ 45,162$ & 4.6 \\
\hline $3 \mathrm{~A}$ & Atlanta & $\$ 211,909$ & $\$ 33,802$ & $\$ 383$ & $\$ 34,185$ & 6.2 \\
\hline 3B & Los Angeles & $\$ 202,249$ & $\$ 37,251$ & $\$ 57$ & $\$ 37,308$ & 5.4 \\
\hline 3B & Las Vegas & $\$ 178,072$ & $\$ 41,428$ & $(\$ 144)$ & $\$ 41,283$ & 4.3 \\
\hline $3 \mathrm{C}$ & San Fran. & $\$ 208,022$ & $\$ 40,506$ & $(\$ 344)$ & $\$ 40,162$ & 5.2 \\
\hline $4 \mathrm{~A}$ & Baltimore & $\$ 196,787$ & $\$ 37,212$ & $\$ 412$ & $\$ 37,623$ & 5.2 \\
\hline $4 \mathrm{~B}$ & Albuquerque & $\$ 153,938$ & $\$ 38,993$ & $\$ 124$ & $\$ 39,117$ & 3.9 \\
\hline $4 \mathrm{C}$ & Seattle & $\$ 166,525$ & $\$ 39,965$ & (\$589) & $\$ 39,376$ & 4.2 \\
\hline $5 \mathrm{~A}$ & Chicago & $\$ 190,947$ & $\$ 40,836$ & $\$ 21$ & $\$ 40,857$ & 4.7 \\
\hline $5 B$ & Denver & $\$ 170,321$ & $\$ 39,955$ & $\$ 252$ & $\$ 40,207$ & 4.2 \\
\hline $6 \mathrm{~A}$ & Minneapolis & $\$ 226,165$ & $\$ 40,528$ & $\$ 889$ & $\$ 41,417$ & 5.5 \\
\hline $6 \mathrm{~B}$ & Helena & $\$ 127,134$ & $\$ 38,504$ & $\$ 569$ & $\$ 39,074$ & 3.3 \\
\hline 7 & Duluth & $\$ 164,727$ & $\$ 46,797$ & $\$ 194$ & $\$ 46,991$ & 3.5 \\
\hline 8 & Fairbanks & $\$ 226,041$ & $\$ 44,665$ & $\$ 1,030$ & $\$ 45,694$ & 4.9 \\
\hline
\end{tabular}

\subsection{A Perspective on Costs for Advanced Buildings}

With the growing high performance buildings market, there is a commensurate growth in the desire to understand the real costs associated with energy efficiency measures. Any effort such as the one included in this document is inevitably faced with the challenges of finding credible sources of cost data, particularly when some of the more advanced measures are being considered. The reader will note that the sources for this work run the gamut of widely published data including R.S. Means, engineering consulting firm and contractor budget estimates, code development sources such as the SSPC 90.1 Cost Database or data found on websites and in testimonials. Clearly it would be desirable to have robust costs for all measures, collected in a consistent manner. Unfortunately this situation does not exist, and it is for this reason that identifying costs in a consistent and accurate manner is difficult to execute.

Many choices had to be made in choosing sources of cost data for this study, which involved considering the basis for the data as well as considering whether the source was biased high or low relative to other costs. Generally the authors understand that some sources are routinely high or low, and this impact can usually be mitigated by using the differential costs as noted earlier in this section of the report. Sometimes the actual range of cost estimates is so broad that the authors had to struggle to make a 
reasonable judgment as to which costs to use. When confronted with conflicting or ambiguous costs the general approach followed was to take the conservative view of not underestimating the costs such that the exercise would yield an inflated assessment of the cost-effective nature of the measures. Conversely, every effort was made to not unduly burden the analysis with costs that are systematically too high, thus biasing the results against undertaking these advanced energy design projects.

The result is a reasonable estimate of simple payback values for the advanced energy measure packages in the 16 locations, showing that the packages can do not create an unreasonably high economic burden in pursuing the $50 \%$ energy savings goal. 


\subsection{Recommendations and Energy Savings Results}

This section contains the final recommendations for this TSD report, as well as the energy savings results that are achieved as a result of applying these recommendations to the prototypical building. The recommendations are applicable for all medium office buildings within the scope of the study as a means of demonstrating the $50 \%$ energy savings. There are other ways of achieving $50 \%$ energy savings. These recommendations are "a way, but not the only way" of meeting the energy savings target. When a recommendation contains the designation "NR", then the TSD is not providing a recommendation for this component or system. This analysis used Standard 90.1-2004 baseline or the same values as modeled for the baseline for items not regulated by the Standard.

This section describes the final energy savings recommendations in the TSD. The recommendations are grouped into envelope measures, lighting measures, plug load measures, HVAC measures, and service water heating measures.

\subsubsection{Envelope Measures}

The envelope measures cover the range of assemblies for both the opaque and fenestration portions of the buildings. Opaque elements include the roof, walls, floors and slabs, as well as opaque doors. Fenestration covers the vertical glazing (including doors). For each building element, there are a number of components for which the report provides recommendations. In some cases, these components represent an assembly, such as an attic or a steel-framed wall, or a portion of an assembly, such as insulation R-value.

Recommendations for each envelope component are contained in Table 6.1, and are organized by climate zone, ranging from the hot Zone 1 to the cold Zone 8. Consistent with the movement from the hotter to colder zones, the insulation requirements (R-value) increase as the climates get colder, and corresponding thermal transmittance (U-factor) decreases. Control of solar loads is more important in the hotter, sunnier climates, and thus the solar heat gain coefficient tends to be more stringent (lower) in Zone 1 and higher in Zone 8. The reader should note that the recommendations are based on a steel stud construction with curtain wall style windows (or storefront).

In addition, the TSD recommends using exterior sun control on the south glazing to help control solar cooling loads in warmer climates. 
Table 6.1. Final Energy Savings Recommendations for Medium Office - Building Envelope

\begin{tabular}{|c|c|c|c|c|c|c|c|c|c|c|}
\hline Item & Component & & Zone 1 & Zone 2 & Zone 3 & Zone 4 & Zone 5 & Zone 6 & Zone 7 & Zone 8 \\
\hline \multirow[t]{4}{*}{ Roof } & $\begin{array}{l}\text { Insulation } \\
\text { entirely } \\
\text { above deck }\end{array}$ & $\begin{array}{l}\text { R-value } \\
\mathrm{ft}^{2} \cdot \mathrm{F} \cdot \mathrm{h} / \mathrm{Btu}\end{array}$ & R-20 c.i. & R-25 c.i. & R-25 c.i. & R-30 c.i. & R-30 c.i. & R-30 c.i. & R-35 c.i. & R-35 c.i. \\
\hline & & $\begin{array}{l}R \text {-value } \\
K \cdot m^{2} / W\end{array}$ & R-3.5 c.i. & R-4.4 c.i. & R-4.4 c.i. & 5.3 c.i. & 5.3 c.i. & 5.3 c.i. & 6.2 c.i. & 6.2 c.i. \\
\hline & $\begin{array}{l}\text { Solar } \\
\text { reflectance }\end{array}$ & & 0.69 & 0.69 & 0.69 & NR & NR & NR & NR & NR \\
\hline & Emittance & & 0.87 & 0.87 & 0.87 & NR & NR & NR & NR & NR \\
\hline \multirow[t]{2}{*}{$\begin{array}{l}\text { Walls- } \\
\text { Exterior }\end{array}$} & Steel framed & $\begin{array}{l}\text { R-value } \\
\mathrm{ft}^{2} \cdot \mathrm{F} \cdot \mathrm{h} / \mathrm{Btu}\end{array}$ & $\begin{array}{l}\text { R-13.0 + } \\
\text { R-7.5 c.i. }\end{array}$ & $\begin{array}{l}\text { R-13.0 + } \\
\text { R-7.5 c.i. }\end{array}$ & $\begin{array}{l}\text { R-13.0 + } \\
\text { R-7.5 c.i. }\end{array}$ & $\begin{array}{l}\text { R-13.0 + } \\
\text { R-7.5 c.i. }\end{array}$ & $\begin{array}{l}\text { R-13.0 + } \\
\text { R-15.6 } \\
\text { c.i. }\end{array}$ & $\begin{array}{l}\text { R-13.0 + } \\
\text { R-18.8 } \\
\text { c.i. }\end{array}$ & $\begin{array}{l}\text { R-13.0 + } \\
\text { R-18.8 } \\
\text { c.i. }\end{array}$ & $\begin{array}{l}\text { R-13.0 + } \\
\text { R-18.8 c.i. }\end{array}$ \\
\hline & & $\begin{array}{l}R \text {-value } \\
K \cdot m^{2} / W\end{array}$ & $\begin{array}{l}R-2.3+ \\
R-1.3 \text { c.i. }\end{array}$ & $\begin{array}{l}R-2.3+ \\
R-1.3 \text { c.i. }\end{array}$ & $\begin{array}{l}R-2.3+ \\
R-1.3 \text { c.i. }\end{array}$ & $\begin{array}{l}R-2.3+ \\
R-1.3 \text { c.i. }\end{array}$ & $\begin{array}{l}R-2.3+ \\
R-2.7 \text { c.i. }\end{array}$ & $\begin{array}{l}R-2.3+ \\
R-3.3 \text { c.i. }\end{array}$ & $\begin{array}{l}R-2.3+ \\
R-3.3 \text { c.i. }\end{array}$ & $\begin{array}{l}R-2.3+ \\
R-3.3 \text { c.i. }\end{array}$ \\
\hline \multirow[t]{2}{*}{ Slabs } & Heated & $\begin{array}{l}\text { R-value } \\
\mathrm{ft}^{2} \cdot \mathrm{F} \cdot \mathrm{h} / \mathrm{Btu}\end{array}$ & NR & NR & NR & $\begin{array}{l}\mathrm{R}-10.0 \\
\text { for } 24 \mathrm{in} .\end{array}$ & $\begin{array}{l}R-10.0 \\
\text { for } 24 \text { in. }\end{array}$ & $\begin{array}{l}R-15.0 \\
\text { for } 24 \text { in. }\end{array}$ & $\begin{array}{l}R-15.0 \\
\text { for } 24 \mathrm{in} .\end{array}$ & $\begin{array}{l}\text { R-20.0 for } \\
24 \text { in. }\end{array}$ \\
\hline & & $\begin{array}{l}R \text {-value } \\
K \cdot m^{2} / W\end{array}$ & $N R$ & $N R$ & $N R$ & $\begin{array}{l}R-10.0 \\
\text { for } 24 \text { in. }\end{array}$ & $\begin{array}{l}R-10.0 \\
\text { for } 24 \text { in. }\end{array}$ & $\begin{array}{l}R-15.0 \\
\text { for } 24 \text { in. }\end{array}$ & $\begin{array}{l}R-15.0 \\
\text { for } 24 \text { in. }\end{array}$ & $\begin{array}{l}R-20.0 \text { for } \\
24 \text { in. }\end{array}$ \\
\hline \multirow[t]{4}{*}{$\begin{array}{l}\text { Vertical } \\
\text { glazing }\end{array}$} & $\begin{array}{l}\text { Thermal } \\
\text { trans- } \\
\text { mittance }\end{array}$ & $\begin{array}{l}\text { U-factor } \\
\text { Btu/h } \cdot \mathrm{ft}^{2} \cdot \mathrm{F}\end{array}$ & 0.51 & 0.51 & 0.51 & 0.44 & 0.44 & 0.42 & 0.31 & 0.31 \\
\hline & & $\begin{array}{l}U \text {-factor } \\
\mathrm{W} / \mathrm{m}^{2} \cdot K\end{array}$ & 2.89 & 2.89 & 2.89 & 2.5 & 2.5 & 2.38 & 1.76 & 1.76 \\
\hline & $\begin{array}{l}\text { Solar heat } \\
\text { gain } \\
\text { coefficient } \\
\text { (SHGC) }\end{array}$ & & 0.25 & 0.25 & 0.25 & 0.26 & 0.26 & 0.35 & 0.4 & 0.4 \\
\hline & $\begin{array}{l}\text { Exterior sun } \\
\text { control } \\
\text { (South only) }\end{array}$ & & $\mathrm{PF}>0.5$ & $\mathrm{PF}>0.5$ & $\mathrm{PF}>0.5$ & $\mathrm{PF}>0.5$ & $\mathrm{PF}>0.5$ & NR & NR & NR \\
\hline
\end{tabular}

\subsubsection{Lighting Measures}

The lighting measures are not climate dependent. As such, the same recommendations are provided for all climate zones. Recommendations are provided for interior lighting, as well as exterior lighting, as shown in Table 6.2.

Interior lighting recommendations include maximum lighting power density (LPD) requirements for the major space types in medium office buildings. Occupancy control recommendations are also provided.

Exterior lighting recommendations include maximum LPD requirements for exterior lighting applications for medium office buildings. 
Table 6.2 Final Energy Savings Recommendations - Lighting

\begin{tabular}{|c|c|c|c|c|c|c|c|}
\hline \multirow[b]{2}{*}{ Item } & \multirow[b]{2}{*}{ Component } & \multicolumn{6}{|c|}{ All Climate Zone Locations } \\
\hline & & & $\mathrm{W} / \mathrm{ft}^{2}$ & $W / m^{2}$ & & $\mathrm{~W} / \mathrm{ft}^{2}$ & $W / m^{2}$ \\
\hline \multirow{9}{*}{ Interior Lig } & Lighting power density & Office, open plan & 0.68 & 7.3 & Office, enclosed & 0.8 & 8.6 \\
\hline & & Conference/meeting & 0.77 & 8.3 & Active storage & 0.64 & 6.9 \\
\hline & & Corridor/transition & 0.50 & 5.4 & Restrooms & 0.82 & 8.8 \\
\hline & & Lounge/recreation & 0.73 & 7.9 & Stairs & 0.6 & 6.5 \\
\hline & & Electrical/mechanical & 1.24 & 13.3 & Lobby & 1.09 & 11.7 \\
\hline & & Other & 0.82 & 8.8 & OVERALL & 0.75 & 8.1 \\
\hline & Fluorescent lamps & \multicolumn{6}{|c|}{$\begin{array}{l}\text { T5HO or T8 high-performance with high-performance electronic ballast and compact } \\
\text { fluorescent (CFL) with electronic ballast, }\end{array}$} \\
\hline & Occupancy controls & \multicolumn{6}{|c|}{$\begin{array}{l}\text { Added for open-office task lights, enclosed office ambient lighting, active storage, } \\
\text { restrooms and electrical/mechanical spaces. }\end{array}$} \\
\hline & Plug load lighting & \multicolumn{6}{|c|}{ Compact fluorescent (CFL) with electronic ballast } \\
\hline
\end{tabular}

$\ddot{\omega}$

\begin{tabular}{clcc} 
& Base allowance & \multicolumn{2}{c}{$750 \mathrm{~W}$} \\
\cline { 2 - 3 } \multirow{2}{*}{$\begin{array}{c}\text { Exterior Lighting Power } \\
\text { Density }\end{array}$} & Parking areas and drives & $\mathrm{W} / \mathrm{ft}^{2}$ & $\mathrm{~W} / \mathrm{m}^{2}$ \\
\cline { 2 - 3 } & Walkways & 0.100 & 1.08 \\
& Entry canopies & 0.160 & 1.72 \\
& Façade (use wattage only for façade) & 0.400 & 4.31 \\
\hline
\end{tabular}




\subsubsection{Plug Load Measures}

The plug load measures are not climate dependent. As such, the same recommendations for plug equipment and controls are provided for all climate zones as shown in Table 6.3.

Plug load recommendations include several strategies that reduced the connected wattage, and control equipment to further reduce average energy usage. The connected wattage recommendations include shifting towards greater use of laptop computers from desktop computers, and selection of ENERGY STAR computers, monitors and other equipment for all office equipment with ENERGY STAR ratings. The controls strategies include power management software for networked computers, occupancy sensor control of plug strips or outlets for equipment that can be turned off, vending machine occupancy sensor controls and timer switches for equipment that do not need to be on during off-hours such as coffee makers and water coolers. Table 6.3 summarizes these changes.

Table 6.3 Final Energy Savings Recommendations - Plug Loads

\begin{tabular}{|c|c|}
\hline Component & $\begin{array}{l}\text { Recommendations } \\
\quad \text { (for Zones 1-8) }\end{array}$ \\
\hline $\begin{array}{l}\text { Computers-mix of desktop and laptop } \\
\text { computers }\end{array}$ & $\begin{array}{l}\text { Increase proportion of laptop } \\
\text { computers to desktop } \\
\text { computers for primary } \\
\text { computer workstations to at } \\
\text { least } 67 \% \text { of computers. }\end{array}$ \\
\hline $\begin{array}{l}\text { Computers- servers, desktop, laptop } \\
\text { Monitors, laser printers, copy } \\
\text { machines, fax machines, water } \\
\text { coolers, refrigerators }\end{array}$ & $\begin{array}{l}\text { Use ENERGY STAR } \\
\text { equipment }\end{array}$ \\
\hline Computers - desktop, laptop & $\begin{array}{l}\text { Apply power management } \\
\text { software and activation across } \\
\text { all computers }\end{array}$ \\
\hline $\begin{array}{l}\text { Computer monitors, portable HVAC } \\
\text { (heaters, fans), other small appliances } \\
\text { and chargers }\end{array}$ & $\begin{array}{l}\text { Occupancy sensor plug strips, } \\
\text { or selected outlet occupancy } \\
\text { sensor controls in conjunction } \\
\text { with lighting control }\end{array}$ \\
\hline Water coolers, coffee makers & $\begin{array}{l}\text { Use timer switches set to turn } \\
\text { off equipment during off-hours }\end{array}$ \\
\hline Overall plug loads power density & $0.55 \mathrm{~W} / \mathrm{ft}^{2}\left(5.92 \mathrm{~W} / \mathrm{m}^{2}\right)$ \\
\hline
\end{tabular}

\subsubsection{HVAC Measures}

HVAC measures include systems for space heating and sensible cooling with separate conditioning for ventilation air, which also provides latent cooling including dehumidification. Radiant systems with dedicated outdoor air units (DOAS) is recommended and summarized here. 
An alternative VAV system approach was originally considered, but achieved a savings of $46.5 \%$ (Section 6.2) short of the 50\% savings target on a weighted average basis for all climates. This alternative system is described in Section 5.5 .

Recommended space heating and sensible cooling system is radiant floors, ceiling and/or wall panels as appropriate to heating and cooling load conditions. Typically for design and cost control the whole building or certainly individual zones would be served by one type of radiant system, typically radiant floor, or ceiling. To allow zonal control for areas that may be in cooling while other zones are in heating, recommended system is provided with a four pipe distribution system with heated and chilled water. The primary heating source for the radiant system is a condensing and modulating gas boiler. The primary cooling source for the radiant system is an air-cooled chiller.

Recommended conditioning of ventilation air and all latent cooling is through a dedicated outdoor air unit serving the entire building. The dedicated outdoor air unit uses a DX coil for primary cooling, and a hot water coil for primary heating (served by the condensing boiler that also serves the radiant system. Energy recovery is included to temper the outside air (both sensible and latent) before it enters the cooling and heating coils. For most dry climate zones, supply air is cooled to as low as $55^{\circ} \mathrm{F}\left(12.8^{\circ} \mathrm{C}\right)$ as required to provide adequate latent load control and supplemental space cooling. In the most humid climates, the supply air is first cooled to as low as $45^{\circ} \mathrm{F}\left(7.2^{\circ} \mathrm{C}\right)$ for dehumidification and is then reheated with an additional sensible heat recovery device. DX cooling efficiency for the DOAS unit is provided in Table 6.4 .

Table 6.4 Final Energy Savings Recommendations - HVAC

\begin{tabular}{|c|c|c|}
\hline Component & \multicolumn{2}{|c|}{ Zones $1-8$ or as noted below } \\
\hline Radiant systems & Primary space sensible heating and cooling & $\begin{array}{l}\text { Floor or ceiling radiant } \\
\text { systems as appropriate to } \\
\text { meet loads }\end{array}$ \\
\hline Chiller - air-cooled & Chilled water for radiant system & $\begin{array}{l}\text { 3.1 COP/Table A.5 for } \\
\text { performance curve }\end{array}$ \\
\hline Boiler - condensing & Hot water for radiant system and DOAS & $95 \% \mathrm{Et}$ \\
\hline \multirow{7}{*}{$\begin{array}{l}\text { Dedicated outdoor } \\
\text { air }\end{array}$} & $\begin{array}{l}\text { Conditioning of ventilation air and all latent } \\
\text { cooling }\end{array}$ & $100 \%$ outside air \\
\hline & $<65,000 \mathrm{Btu} / \mathrm{h}(<19 \mathrm{~kW})$ & 13.5 SEER \\
\hline & DX cooling 65-135 kBtu/h (19-40 kW) & 11.3 EER/11.5 IPLV \\
\hline & DX cooling 135-240 kBtu/h $(40-70 \mathrm{~kW})$ & 11.0 EER/11.5 IPLV \\
\hline & Heating - hot water coil served by boiler & See boiler above \\
\hline & Energy Recovery & Effectiveness: see Table 4.10. \\
\hline & $\begin{array}{l}\text { Additional dehumidification with sub-cooling } \\
\text { and energy recovery reheating }\end{array}$ & $\begin{array}{l}\text { Hot and humid climate zones } \\
(1 \mathrm{~A}, 2 \mathrm{~A}, 3 \mathrm{~A} \text {, and } 4 \mathrm{~A})\end{array}$ \\
\hline
\end{tabular}




\subsubsection{Service Water Heating Measures}

Service water heating is a modest energy use in medium offices. For a medium office building, a circulating water heating system would be typical and appropriate if the restrooms, sinks, and other service hot water supply equipment is located near the core of the building. A single gas-fired condensing water heater, with 95\% efficiency and with typical storage is recommended. If there are service water heating uses that are distributed outside the core, it may be more beneficial from an energy (and possibly first cost) perspective to use on-demand water heaters to serve these uses.

\subsection{Energy Savings Results}

The prototype medium office building was simulated in each of the 16 climate locations to determine if the 50\% energy savings goal was achieved. The whole building energy savings results for the recommendations are shown below. In all cases the energy savings are relative to the baseline energy use from Standard 90.1-2004. A radiant system approach with dedicated outdoor air systems is part of the recommended package. During the analysis, a variable air volume HVAC approach was first tried for the advanced case with other measures, and did not quite reach the $50 \%$ savings goal.

\subsubsection{Results with Radiant Systems and Dedicated Outdoor Air}

The recommended package of energy efficient measures presented in Section 4 can achieve over 50\% on-site energy savings for all of the 16 climate locations as shown in Figure 6.1. The weighted average percentage savings for the whole country based on the 16 representative cities is $56.1 \%$ as shown in Table 6.5 using the construction are weighting factors presented in Section 2.3.

To understand the impact of EEMs on different energy end use sectors, the energy end use intensities for the baseline and the advanced model is illustrated in Figure 6.2. The annual energy usage by usage category is shown in Table 6.6.

- On average, there is about $81 \%$ heating energy savings and about $46 \%$ cooling energy savings. The percentage of heating and cooling energy saving varies significantly with the climate locations. For heating, the range is between $72 \%$ for Minneapolis, and $99 \%$ for Miami. For cooling, the range is between $64 \%$ for Baltimore and $-6 \%$ for Fairbanks. The heating and cooling energy savings come from the whole package of energy efficiency measures including building envelope, HVAC, lighting and plug-in equipment.

- There is about $84 \%$ fan energy reduction mainly from the use of radiant thermal systems and DOAS.

- The lighting related measures reduce about $50.5 \%$ of interior lighting energy and $72 \%$ of exterior lighting energy. The above percentages are observed to be nearly the same across all 16 climate locations.

- Plug-in electric equipment energy is reduced by about $31 \%$ because of changes in equipment and the controls.

- Water heater efficiency improvement leads to about $16 \%$ energy reduction for service hot water.

- For the advanced case, pumping and heat rejection auxiliary energy usage add about $1 \%$ to the advanced case energy usage with negligible corresponding energy usage for the baseline. 


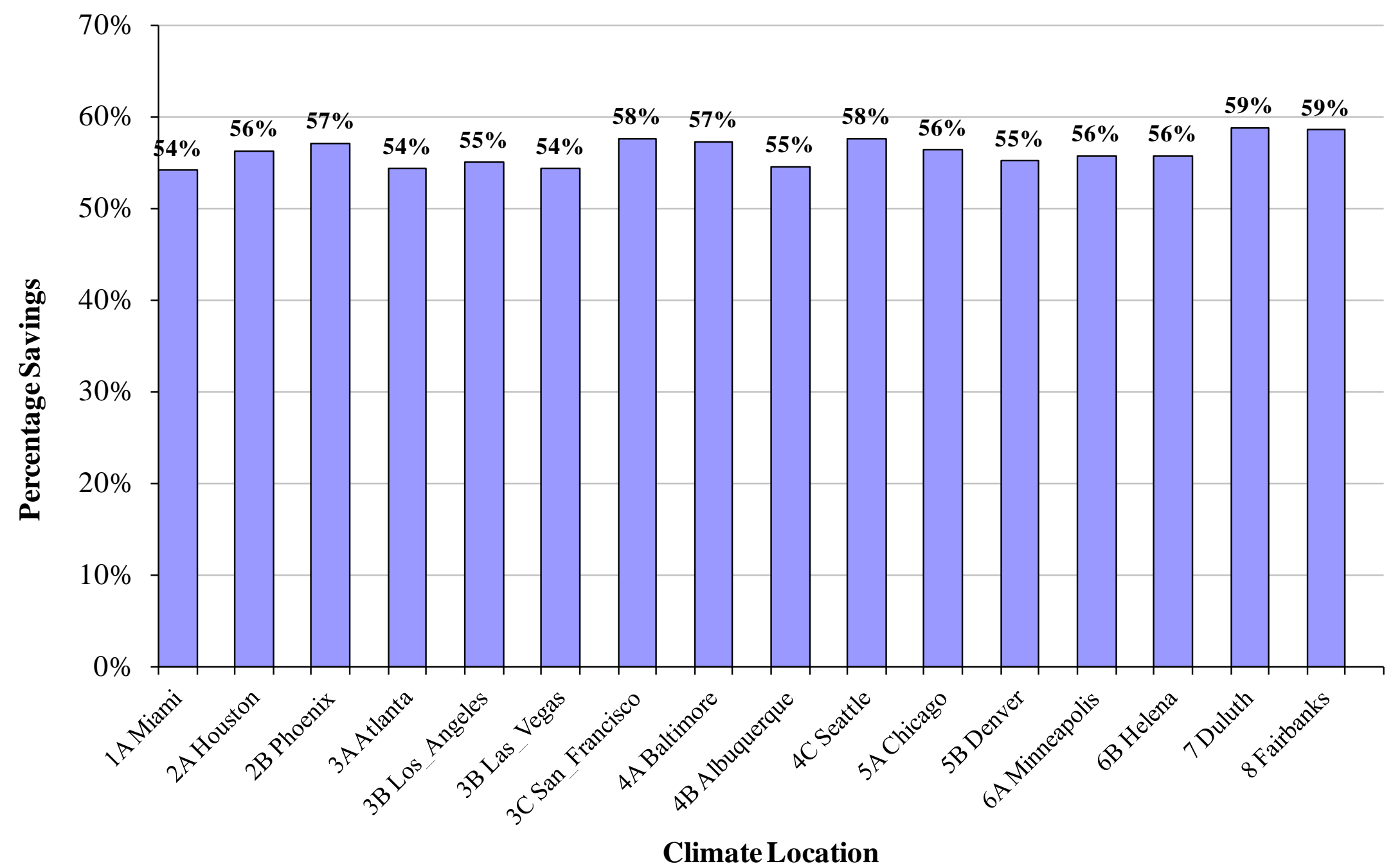

Figure 6.1. Percentage Energy Savings by Climate Zone (Radiant System) 
Table 6.5 Weighted Average Energy Savings for Recommended Energy Measures (Radiant System)

\begin{tabular}{|c|c|c|c|c|c|c|c|c|c|}
\hline & $\begin{array}{c}\text { 1A } \\
\text { Miami }\end{array}$ & $\begin{array}{c}\text { 2A } \\
\text { Houston }\end{array}$ & $\begin{array}{c}\text { 2B } \\
\text { Phoenix }\end{array}$ & $\begin{array}{c}\text { 3A } \\
\text { Atlanta }\end{array}$ & $\begin{array}{c}\text { 3B-CA } \\
\text { Los } \\
\text { Angeles }\end{array}$ & $\begin{array}{c}\text { 3B-other } \\
\text { Las } \\
\text { Vegas } \\
\end{array}$ & $\begin{array}{c}\text { 3C } \\
\text { San } \\
\text { Francisco } \\
\end{array}$ & $\begin{array}{c}\text { 4A } \\
\text { Baltimore }\end{array}$ & \\
\hline Baseline EUI, kBtu/ $\mathrm{ft}^{2}$ & 55.8 & 57.6 & 57.7 & 55.6 & 48.1 & 54.5 & 50.5 & 60.5 & \\
\hline Advanced EUI, kBtu/ft ${ }^{2}$ & 25.6 & 25.1 & 24.7 & 25.4 & 21.6 & 24.9 & 21.4 & 25.8 & \\
\hline \multirow[t]{2}{*}{ Weighting, \% } & $2.13 \%$ & $13.44 \%$ & $4.83 \%$ & $12.67 \%$ & $5.91 \%$ & $5.91 \%$ & $2.25 \%$ & $19.68 \%$ & \\
\hline & $\begin{array}{c}\text { 4B } \\
\text { Albuquerque }\end{array}$ & $\begin{array}{c}4 \mathrm{C} \\
\text { Seattle }\end{array}$ & $\begin{array}{c}5 \mathrm{~A} \\
\text { Chicago }\end{array}$ & $\begin{array}{c}\text { 5B } \\
\text { Denver }\end{array}$ & $\begin{array}{c}\text { 6A } \\
\text { Minneapolis }\end{array}$ & $\begin{array}{c}\text { 6B } \\
\text { Helena }\end{array}$ & $\begin{array}{c}7 \\
\text { Duluth }\end{array}$ & $\begin{array}{c}8 \\
\text { Fairbanks }\end{array}$ & $\begin{array}{c}\text { Total } \\
\text { Weighted } \\
\text { Average }\end{array}$ \\
\hline Baseline EUI, kBtu/ft² & 54.7 & 54.6 & 60.7 & 56.0 & 64.5 & 59.4 & 67.1 & 75.6 & 57.7 \\
\hline Advanced EUI, kBtu/ft² & 24.8 & 23.1 & 26.4 & 25.1 & 28.5 & 26.3 & 27.6 & 31.3 & 25.3 \\
\hline Weighting, \% & $0.60 \%$ & $3.24 \%$ & $17.53 \%$ & $5.65 \%$ & $4.93 \%$ & $0.58 \%$ & $0.55 \%$ & $0.12 \%$ & $56.1 \%$ \\
\hline
\end{tabular}




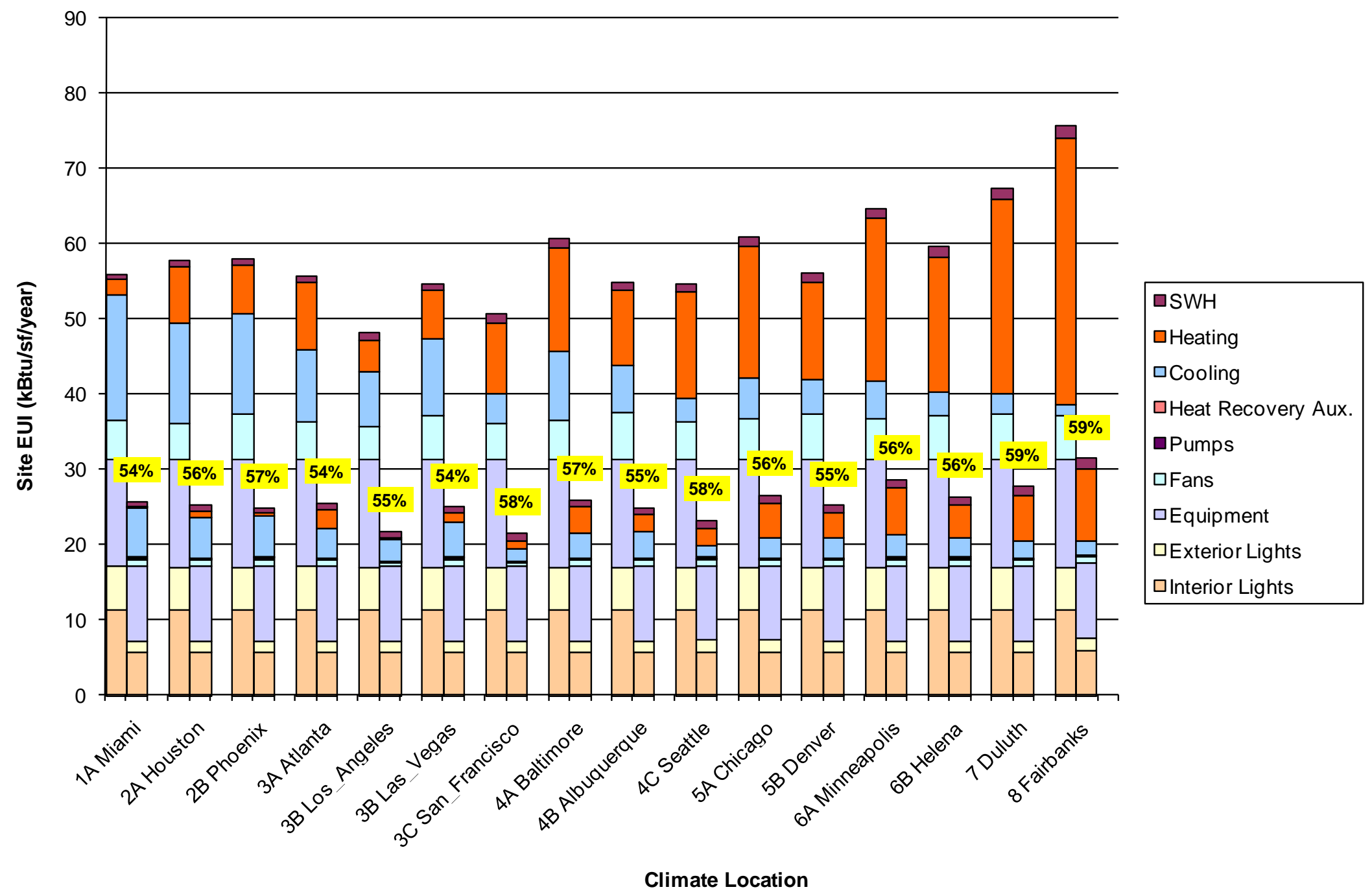

Figure 6.2. Comparison of Energy End Use Intensities Between the Baseline and Advanced Models (Radiant System) 
Table 6.6 Energy Savings Results by End Use (Radiant System)

\begin{tabular}{|c|c|c|c|c|c|c|c|c|c|c|c|c|c|c|}
\hline Zone & City & Case & $\begin{array}{l}\text { Heating } \\
\text { [MMBtu] }\end{array}$ & $\begin{array}{l}\text { Cooling } \\
\text { [MMBtu] }\end{array}$ & $\begin{array}{c}\text { Interior } \\
\text { Lights } \\
\text { [MMBtu] }\end{array}$ & $\begin{array}{c}\text { Exterior } \\
\text { Lights } \\
\text { [MMBtu] }\end{array}$ & $\begin{array}{c}\text { Interior } \\
\text { Equipment } \\
\text { [MMBtu] }\end{array}$ & $\begin{array}{c}\text { Fans } \\
{[M M B t u]}\end{array}$ & $\begin{array}{c}\text { Pumps } \\
\text { [MMBtu] }\end{array}$ & $\begin{array}{c}\text { Heat } \\
\text { Recovery } \\
\text { [MMBtu] }\end{array}$ & $\begin{array}{c}\text { Water } \\
\text { Heater } \\
\text { [MMBtu] }\end{array}$ & $\begin{array}{c}\text { Total } \\
\text { Energy } \\
\text { [MMBtu] }\end{array}$ & $\begin{array}{c}E U I \\
{[k B t u / S F]}\end{array}$ & $\begin{array}{c}\text { Energy } \\
\text { Savings } \\
(\%)\end{array}$ \\
\hline \multirow{2}{*}{$1 \mathrm{~A}$} & \multirow{2}{*}{ Miami } & Baseline & 114 & 890 & 599 & 309 & 768 & 273 & 0 & 0 & 38 & 2,990 & 55.8 & \multirow{2}{*}{$54 \%$} \\
\hline & & Advanced & 2 & 362 & 295 & 86 & 529 & 48 & 14 & 3 & 32 & 1,371 & 25.6 & \\
\hline \multirow{2}{*}{$2 \mathrm{~A}$} & \multirow{2}{*}{ Houston } & Baseline & 401 & 708 & 599 & 308 & 768 & 256 & 0 & 0 & 46 & 3,086 & 57.6 & \multirow{2}{*}{$56 \%$} \\
\hline & & Advanced & 53 & 283 & 296 & 85 & 529 & 48 & 11 & 2 & 39 & 1,348 & 25.1 & \\
\hline \multirow{2}{*}{$2 \mathrm{~B}$} & \multirow{2}{*}{ Phoenix } & Baseline & 339 & 723 & 599 & 308 & 768 & 317 & 0 & 0 & 41 & 3,095 & 57.7 & \multirow{2}{*}{$57 \%$} \\
\hline & & Advanced & 23 & 289 & 295 & 86 & 529 & 48 & 17 & 2 & 35 & 1,325 & 24.7 & \\
\hline \multirow{2}{*}{$3 A$} & \multirow{2}{*}{ Atlanta } & Baseline & 480 & 513 & 599 & 309 & 768 & 260 & 0 & 0 & 54 & 2,982 & 55.6 & \multirow{2}{*}{$54 \%$} \\
\hline & & Advanced & 128 & 214 & 296 & 87 & 529 & 48 & 11 & 2 & 46 & 1,360 & 25.4 & \\
\hline \multirow{2}{*}{ 3B } & \multirow{2}{*}{ Los Angeles } & Baseline & 230 & 390 & 599 & 308 & 768 & 230 & 0 & 0 & 53 & 2,578 & 48.1 & \multirow{2}{*}{$55 \%$} \\
\hline & & Advanced & 8 & 154 & 297 & 85 & 529 & 30 & 10 & 0 & 45 & 1,158 & 21.6 & \\
\hline \multirow{2}{*}{ 3B } & \multirow{2}{*}{ Las Vegas } & Baseline & 349 & 538 & 599 & 308 & 768 & 314 & 0 & 0 & 47 & 2,923 & 54.5 & \multirow{2}{*}{$54 \%$} \\
\hline & & Advanced & 63 & 250 & 297 & 86 & 529 & 48 & 17 & 2 & 40 & 1,332 & 24.9 & \\
\hline \multirow{2}{*}{$3 \mathrm{C}$} & \multirow{2}{*}{ San Francisco } & Baseline & 510 & 212 & 599 & 308 & 768 & 249 & 0 & 0 & 60 & 2,706 & 50.5 & \multirow{2}{*}{$58 \%$} \\
\hline & & Advanced & 56 & 89 & 297 & 86 & 529 & 30 & 8 & 0 & 50 & 1,145 & 21.4 & \\
\hline \multirow{2}{*}{$4 \mathrm{~A}$} & \multirow{2}{*}{ Baltimore } & \begin{tabular}{|l|} 
Baseline \\
\end{tabular} & 739 & 488 & 599 & 308 & 768 & 280 & 0 & 0 & 61 & 3,242 & 60.5 & \multirow{2}{*}{$57 \%$} \\
\hline & & Advanced & 186 & 176 & 296 & 86 & 529 & 48 & 9 & 2 & 51 & 1,383 & 25.8 & \\
\hline \multirow{2}{*}{$4 \mathrm{~B}$} & A thu aurour & Baseline & 525 & 338 & 599 & 308 & 768 & 334 & 0 & 0 & 59 & 2,931 & 54.7 & $550 /$ \\
\hline & Аाँсquerque & Advanced & 126 & 181 & 295 & 85 & 529 & 48 & 14 & 2 & 50 & 1,330 & 24.8 & $35 \%$ \\
\hline $4 \mathrm{C}$ & Seattle & Baseline & 758 & 165 & 599 & 308 & 768 & 263 & 0 & 0 & 64 & 2,925 & 54.6 & $58 \%$ \\
\hline & & Advanced & 122 & 86 & 300 & 88 & 529 & 48 & 8 & 2 & 54 & 1,237 & 23.1 & \\
\hline $5 \mathrm{~A}$ & Chicaðo & \begin{tabular}{|l|} 
Baseline \\
\end{tabular} & 930 & 296 & 599 & 308 & 768 & 287 & 0 & 0 & 66 & 3,254 & 60.7 & $56 \%$ \\
\hline$J A$ & Cincago & Advanced & 246 & 142 & 297 & 87 & 529 & 48 & 10 & 2 & 56 & 1,417 & 26.4 & 5070 \\
\hline $5 \mathrm{~B}$ & Denver & Baseline & 690 & 245 & 599 & 308 & 768 & 323 & 0 & 0 & 66 & 2,999 & 56.0 & $55 \%$ \\
\hline JD & Deriver & Advanced & 174 & 140 & 296 & 86 & 529 & 48 & 12 & 2 & 56 & 1,343 & 25.1 & 3570 \\
\hline $6 \mathrm{~A}$ & Minneapolis & Baseline & 1160 & 262 & 599 & 308 & 768 & 292 & 0 & 0 & 71 & 3,460 & 64.5 & $56 \%$ \\
\hline & & Advanced & 331 & 165 & 295 & 87 & 529 & 48 & 14 & 2 & 60 & 1,530 & 28.5 & \\
\hline $6 \mathrm{P}$ & Holon & Baseline & 961 & 169 & 599 & 308 & 768 & 309 & 0 & 0 & 72 & 3,185 & 59.4 & 560 \\
\hline ( & (1еienta & Advanced & 235 & 139 & 295 & 88 & 529 & 48 & 13 & 2 & 60 & 1,409 & 26.3 & $50 \%$ \\
\hline 7 & Duluth & Baseline & 1374 & 154 & 599 & 308 & 768 & 317 & 0 & 0 & 79 & 3,598 & 67.1 & $59 \%$ \\
\hline & & Advanced & 320 & 120 & 295 & 88 & 529 & 48 & 12 & 2 & 66 & 1,480 & 27.6 & \\
\hline 8 & Fairbanks & Baseline & 1897 & 88 & 599 & 306 & 768 & 308 & 0 & 0 & 88 & 4,053 & 75.6 & $59 \%$ \\
\hline 0 & T tantains & Advanced & 517 & 93 & 306 & 98 & 529 & 48 & 11 & 2 & 74 & 1,678 & 31.3 & \\
\hline
\end{tabular}




\subsubsection{Results with Variable Air Volume Systems}

Although the proposed measures based on the VAV system cannot reach the $50 \%$ target for all locations, the energy saving results are still presented in this section. The information is intended to show that: 1 ) the VAV-based system can achieve close or above $50 \%$ energy savings for some climate zones (in this case, the VAV system is an alternative approach to be adopted other than the radiant system); 2) how much the gap is if the VAV system cannot achieve 50\% energy saving for a climate zone.

The package of energy efficient measures presented in Section 4 can achieve over $50 \%$ on-site energy savings for 4 of the 16 climate locations and over $42 \%$ for the remaining 12 climate zones as shown in Figure 6.3. The weighted average percentage savings for the whole country based on the 16 representative cities is $46.3 \%$ as shown in Table 6.7 using the construction are weighting factors in Section 2.3.

To understand the impact of EEMs on different energy end use sectors, the energy end use intensities for each baseline and the advanced models are illustrated in Figure 6.4. The annual energy usage by usage category is shown in Table 6.8.

- On average, there is about $58 \%$ heating energy savings and about $56 \%$ cooling energy savings. The percentage of heating and cooling energy saving varies significantly with the climate locations. For heating, the range is between $79 \%$ for Phoenix, and $23 \%$ for Atlanta. For cooling, the range is between $80 \%$ for San Francisco and 24\% for Helena. Building envelope, HVAC and reduced lighting and plug loads all impact these savings.

- There is about 35\% fan energy reduction related to heating and cooling reduction.

- The lighting related measures reduce about $51 \%$ of interior lighting energy and $72 \%$ of exterior lighting energy. The above percentages are observed to be nearly the same across all 16 climate locations.

- Plug-in electric equipment energy is reduced by about $31 \%$ because of changes in equipment and added controls.

- Service water heating is reduced $16 \%$ through water heater efficiency. 


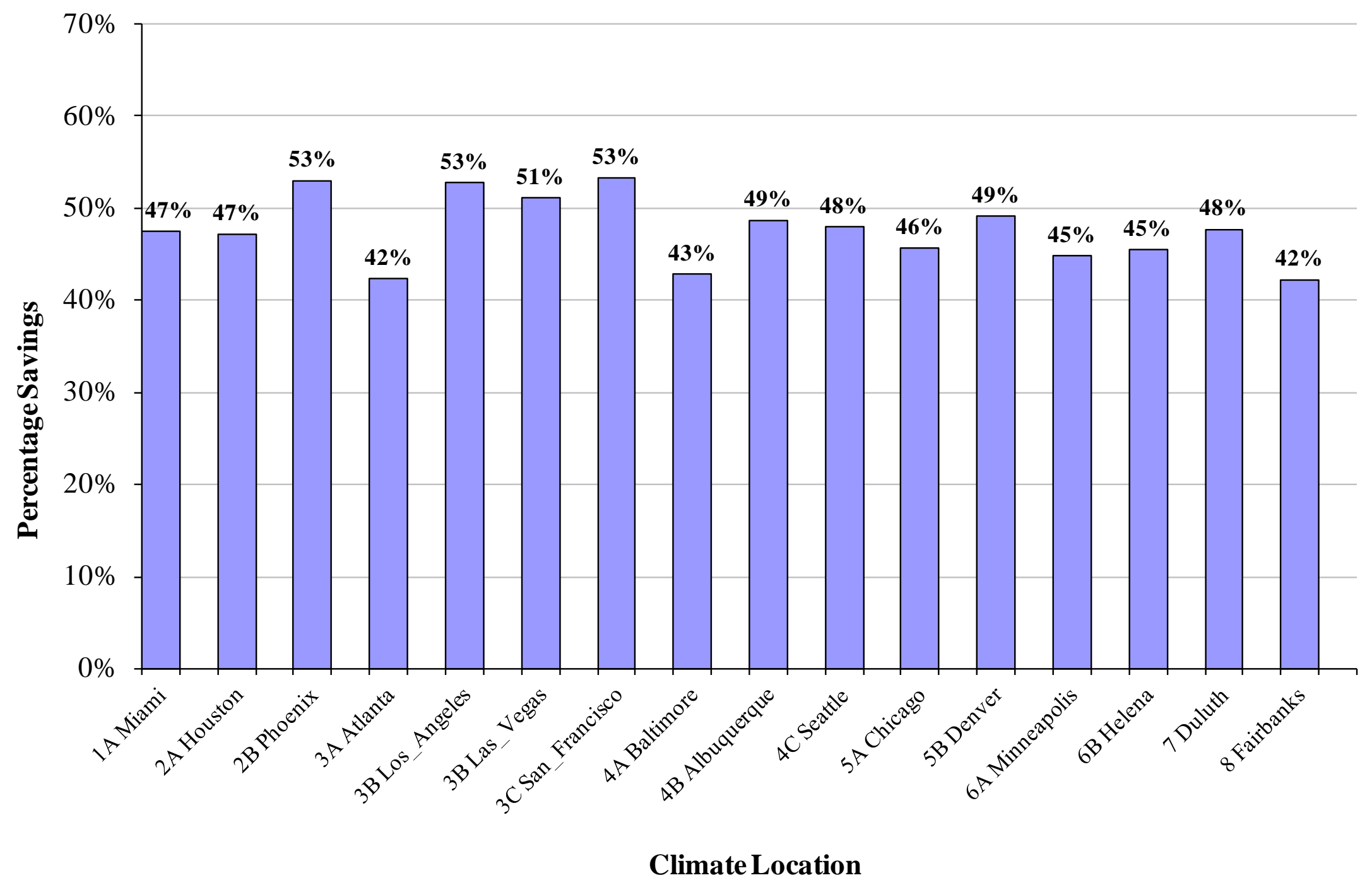

Figure 6.3. Percentage Energy Savings by Climate Zone (VAV System) 
Table 6.7 Weighted Average Energy Savings for Recommended Energy Measures (VAV System)

\begin{tabular}{|c|c|c|c|c|c|c|c|c|c|}
\hline & $\begin{array}{c}\text { 1A } \\
\text { Miami }\end{array}$ & $\begin{array}{c}\text { 2A } \\
\text { Houston }\end{array}$ & $\begin{array}{c}\text { 2B } \\
\text { Phoenix }\end{array}$ & $\begin{array}{c}\text { 3A } \\
\text { Atlanta }\end{array}$ & $\begin{array}{c}\text { 3B-CA } \\
\text { Los } \\
\text { Angeles }\end{array}$ & $\begin{array}{c}\text { 3B-other } \\
\text { Las } \\
\text { Vegas }\end{array}$ & $\begin{array}{c}3 \mathrm{C} \\
\text { San } \\
\text { Francisco }\end{array}$ & $\begin{array}{c}4 \mathrm{~A} \\
\text { Baltimore }\end{array}$ & \\
\hline Baseline EUI, kBtu/ $\mathrm{ft}^{2}$ & 55.8 & 57.6 & 57.7 & 55.6 & 48.1 & 54.5 & 50.5 & 60.5 & \\
\hline Advanced EUI, kBtu/ft² & 29.3 & 30.4 & 27.1 & 32.1 & 22.7 & 26.7 & 23.6 & 34.6 & \\
\hline \multirow[t]{2}{*}{ Weighting, \% } & $2.13 \%$ & $13.44 \%$ & $4.83 \%$ & $12.67 \%$ & $5.91 \%$ & $5.91 \%$ & $2.25 \%$ & $19.68 \%$ & \\
\hline & $\begin{array}{c}\text { 4B } \\
\text { Albuquerque }\end{array}$ & $\begin{array}{c}4 \mathrm{C} \\
\text { Seattle }\end{array}$ & $\begin{array}{c}\text { 5A } \\
\text { Chicago }\end{array}$ & $\begin{array}{c}\text { 5B } \\
\text { Denver }\end{array}$ & $\begin{array}{c}\text { 6A } \\
\text { Minneapolis }\end{array}$ & $\begin{array}{c}\text { 6B } \\
\text { Helena }\end{array}$ & $\begin{array}{c}7 \\
\text { Duluth }\end{array}$ & $\begin{array}{c}8 \\
\text { Fairbanks }\end{array}$ & $\begin{array}{c}\text { Total } \\
\text { Weighted } \\
\text { Average }\end{array}$ \\
\hline Baseline EUI, kBtu/ft² & 54.7 & 54.6 & 60.7 & 56.0 & 64.5 & 59.4 & 67.1 & 75.6 & 57.7 \\
\hline Advanced EUI, kBtu/ft² & 28.0 & 28.4 & 33.0 & 28.5 & 35.6 & 32.4 & 35.1 & 43.7 & 31.0 \\
\hline Weighting, \% & $0.60 \%$ & $3.24 \%$ & $17.53 \%$ & $5.65 \%$ & $4.93 \%$ & $0.58 \%$ & $0.55 \%$ & $0.12 \%$ & $46.3 \%$ \\
\hline
\end{tabular}




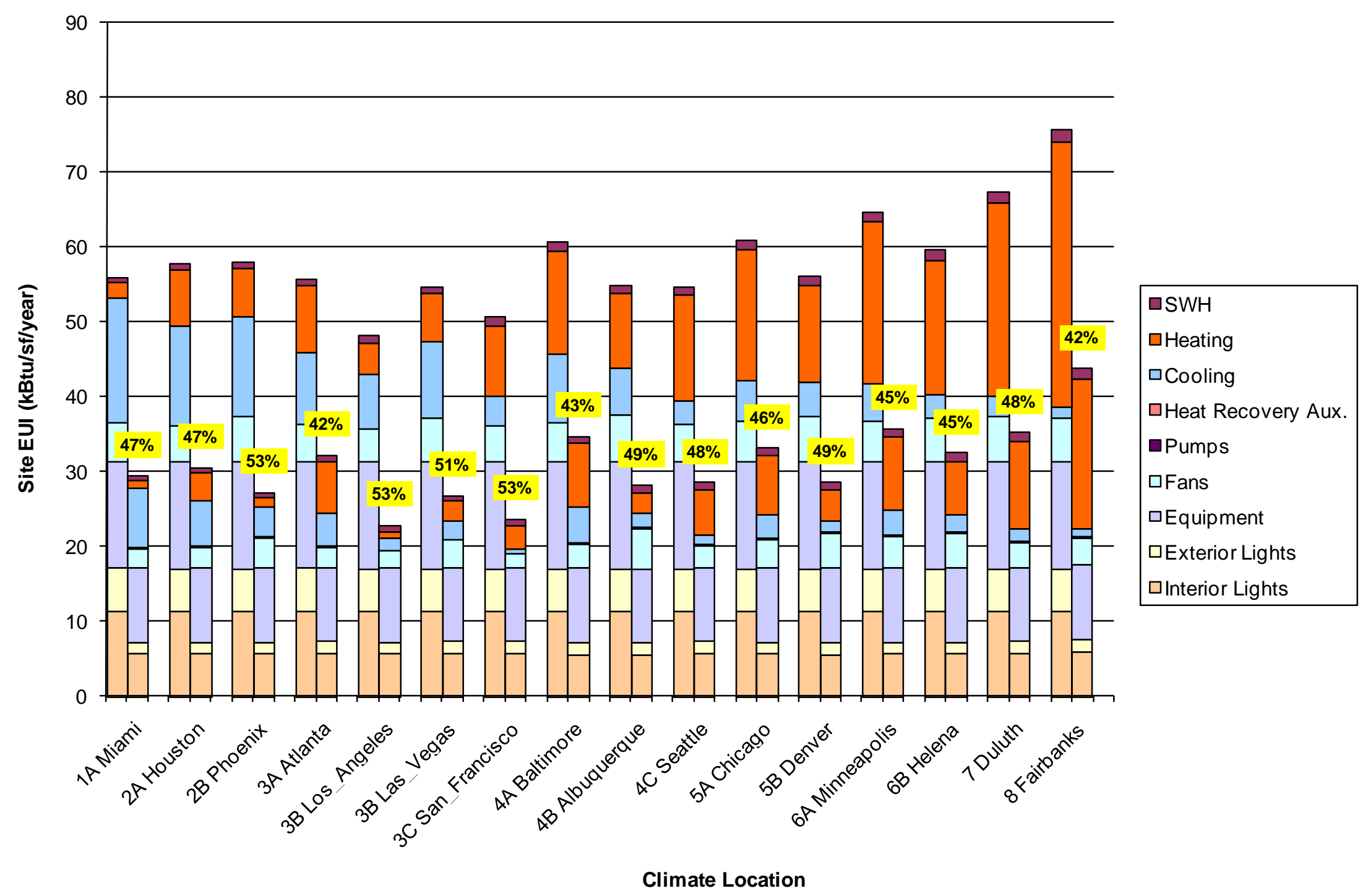

Figure 6.4. Comparison of Energy End Use Intensities Between the Baseline and Advanced Models (VAV System) 
Table 6.8 Energy Savings Results by End Use (VAV System)

\begin{tabular}{|c|c|c|c|c|c|c|c|c|c|c|c|c|c|c|}
\hline Zone & City & Case & $\begin{array}{l}\text { Heating } \\
\text { [MMBtu] }\end{array}$ & $\begin{array}{c}\text { Cooling } \\
\text { [MMBtu] }\end{array}$ & $\begin{array}{c}\text { Interior } \\
\text { Lights } \\
\text { [MMBtu] }\end{array}$ & $\begin{array}{c}\text { Exterior } \\
\text { Lights } \\
\text { [MMBtu] }\end{array}$ & $\begin{array}{c}\text { Interior } \\
\text { Equipment } \\
\text { [MMBtu] }\end{array}$ & $\begin{array}{c}\text { Fans } \\
{[M M B t u]}\end{array}$ & $\begin{array}{c}\text { Pumps } \\
\text { [MMBtu] }\end{array}$ & $\begin{array}{c}\text { Heat } \\
\text { Recovery } \\
\text { [MMBtu] }\end{array}$ & $\begin{array}{c}\text { Water } \\
\text { Heater } \\
\text { [MMBtu] }\end{array}$ & $\begin{array}{c}\text { Total } \\
\text { Energy } \\
\text { [MMBtu] }\end{array}$ & $\begin{array}{c}E U I \\
{[k B t u / S F]}\end{array}$ & $\begin{array}{c}\text { Energy } \\
\text { Savings } \\
(\%) \\
\end{array}$ \\
\hline \multirow{2}{*}{$1 \mathrm{~A}$} & \multirow{2}{*}{ Miami } & Baseline & 114 & 890 & 599 & 309 & 768 & 273 & 0 & 0 & 38 & 2,990 & 55.8 & \multirow{2}{*}{$47 \%$} \\
\hline & & Advanced & 51 & 424 & 296 & 86 & 529 & 145 & 0 & 8 & 32 & 1,571 & 29.3 & \\
\hline \multirow{2}{*}{$2 \mathrm{~A}$} & \multirow{2}{*}{ Houston } & Baseline & 401 & 708 & 599 & 308 & 768 & 256 & 0 & 0 & 46 & 3,086 & 57.6 & \multirow{2}{*}{$47 \%$} \\
\hline & & Advanced & 202 & 323 & 297 & 85 & 529 & 146 & 0 & 7 & 39 & 1,629 & 30.4 & \\
\hline \multirow{2}{*}{$2 \mathrm{~B}$} & \multirow{2}{*}{ Phoenix } & Baseline & 339 & 723 & 599 & 308 & 768 & 317 & 0 & 0 & 41 & 3,095 & 57.7 & \multirow{2}{*}{$53 \%$} \\
\hline & & Advanced & 71 & 207 & 296 & 86 & 529 & 224 & 0 & 5 & 35 & 1,454 & 27.1 & \\
\hline \multirow{2}{*}{$3 \mathrm{~A}$} & \multirow{2}{*}{ Atlanta } & Baseline & 480 & 513 & 599 & 309 & 768 & 260 & 0 & 0 & 54 & 2,982 & 55.6 & \multirow{2}{*}{$42 \%$} \\
\hline & & Advanced & 368 & 241 & 297 & 87 & 529 & 146 & 0 & 6 & 46 & 1,720 & 32.1 & \\
\hline \multirow{2}{*}{ 3B } & \multirow{2}{*}{ Los Angeles } & Baseline & 230 & 390 & 599 & 308 & 768 & 230 & 0 & 0 & 53 & 2,578 & 48.1 & \multirow{2}{*}{$53 \%$} \\
\hline & & Advanced & 50 & 90 & 298 & 85 & 529 & 122 & 0 & 0 & 45 & 1,219 & 22.7 & \\
\hline \multirow{2}{*}{ 3B } & \multirow{2}{*}{ Las Vegas } & Bas eline & 349 & 538 & 599 & 308 & 768 & 314 & 0 & 0 & 47 & 2,923 & 54.5 & \multirow{2}{*}{$51 \%$} \\
\hline & & Advanced & 139 & 140 & 298 & 86 & 529 & 197 & 0 & 0 & 40 & 1,429 & 26.7 & \\
\hline \multirow{2}{*}{$3 C$} & \multirow{2}{*}{ San Francisco } & Baseline & 510 & 212 & 599 & 308 & 768 & 249 & 0 & 0 & 60 & 2,706 & 50.5 & \multirow{2}{*}{$53 \%$} \\
\hline & & Advanced & 161 & 42 & 299 & 86 & 529 & 97 & 0 & 0 & 50 & 1,263 & 23.6 & \\
\hline \multirow{2}{*}{$4 \mathrm{~A}$} & \multirow{2}{*}{ Baltimore } & Baseline & 739 & 488 & 599 & 308 & 768 & 280 & 0 & 0 & 61 & 3,242 & 60.5 & \multirow{2}{*}{$43 \%$} \\
\hline & & Advanced & 454 & 255 & 293 & 86 & 529 & 179 & 0 & 6 & 51 & 1,854 & 34.6 & \\
\hline \multirow{2}{*}{$4 \mathrm{~B}$} & Albuayeraue & Baseline & 525 & 338 & 599 & 308 & 768 & 334 & 0 & 0 & 59 & 2,931 & 54.7 & $49 \%$ \\
\hline & से & Advanced & 148 & 107 & 293 & 85 & 529 & 286 & 0 & 4 & 50 & 1,503 & 28.0 & 40 \\
\hline $4 \mathrm{C}$ & Seattle & Baseline & 758 & 165 & 599 & 308 & 768 & 263 & 0 & 0 & 64 & 2,925 & 54.6 & $48 \%$ \\
\hline 40 & & Advanced & 317 & 72 & 296 & 88 & 529 & 165 & 0 & 3 & 54 & 1,523 & 28.4 & $40 \%$ \\
\hline $5 A$ & Chicaqo & Bas eline & 930 & 296 & 599 & 308 & 768 & 287 & 0 & 0 & 66 & 3,254 & 60.7 & $46 \%$ \\
\hline $3 \pi$ & Cincago & Advanced & 419 & 172 & 295 & 87 & 529 & 205 & 0 & 5 & 56 & 1,767 & 33.0 & 4070 \\
\hline $5 \mathrm{~B}$ & Denver & Baseline & 690 & 245 & 599 & 308 & 768 & 323 & 0 & 0 & 66 & 2,999 & 56.0 & $49 \%$ \\
\hline SD & Denivel & Advanced & 224 & 71 & 294 & 86 & 529 & 262 & 0 & 4 & 56 & 1,525 & 28.5 & 4570 \\
\hline $6 \mathrm{~A}$ & Minneanolis & Baseline & 1160 & 262 & 599 & 308 & 768 & 292 & 0 & 0 & 71 & 3,460 & 64.5 & $45 \%$ \\
\hline $0 \pi$ & 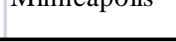 & Advanced & 525 & 174 & 294 & 87 & 529 & 236 & 0 & 5 & 60 & 1,910 & 35.6 & $45 \%$ \\
\hline $6 \mathrm{~B}$ & Helena & Baseline & 961 & 169 & 599 & 308 & 768 & 309 & 0 & 0 & 72 & 3,185 & 59.4 & $45 \%$ \\
\hline - & 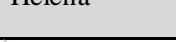 & Advanced & 383 & 128 & 294 & 88 & 529 & 249 & 0 & 5 & 60 & 1,736 & 32.4 & 4570 \\
\hline 7 & Duluth & Baseline & 1374 & 154 & 599 & 308 & 768 & 317 & 0 & 0 & 79 & 3,598 & 67.1 & $48 \%$ \\
\hline 7 & & Advanced & 627 & 79 & 296 & 88 & 529 & 191 & 0 & 5 & 66 & 1,881 & 35.1 & \\
\hline 8 & Fairbanks & Baseline & 1897 & 88 & 599 & 306 & 768 & 308 & 0 & 0 & 88 & 4,053 & 75.6 & $42 \%$ \\
\hline 0 & I tambainns & Advanced & 1076 & 56 & 307 & 98 & 529 & 196 & 0 & 6 & 74 & 2,341 & 43.7 & 4270 \\
\hline
\end{tabular}




\subsection{Suggestions for Future Work}

The TSD work focuses on onsite energy savings for a package of measures to achieve an overall percentage savings target. There may be additional goals and approaches worth considering for possible future TSD work. There are also specific potential adjustments to the prototype and baseline model as well as additional energy measures that can be investigated further.

\subsection{Purpose and Goals}

The goals for future TSD work could be expanded to consider more than just on-site energy savings above a certain target for entire packages of energy measures.

- There may be value in considering the long-term performance differences between the baseline and advanced options, and maintenance and operations of energy measures including impacts on costeffectiveness.

- With a growing focus for energy efficiency to contribute to combating global climate change by reducing carbon dioxide emissions, may want to consider source energy in addition to site energy reduction and report on the impact of the energy measures on carbon emissions.

- Additional information on trade-offs between energy measures and optimizing cost effectiveness could be provided by expanding the scope of the analysis to allow evaluation of individual energy measures and to determine the marginal benefit and cost of each measure in a package of measures. to allow trade-offs.

\subsection{Adjustments to Prototypes and Baseline Model}

Some adjustments to the prototype would refine the starting point and facilitate evaluating a number of energy efficiency measures. The following adjustments are suggested:

- Change from ribbon windows to punched windows. Using punched windows offers more opportunities to optimize daylighting and the utilization of solar energy, for example, changing window layouts and using fins.

- Include interior blinds in the prototype. Interior blinds are not considered in the current prototype. However, using interior blinds for glare control may reflect the practice better.

- Consider alternative VAV system configurations. In the current prototype, a VAV system is used for each floor. In many cases, it might be more reasonable to assign thermal zones to VAV systems according to orientation or perimeter and core.

- Consider separate interior zones for computer rooms and conference rooms that have quite different occupancy schedules and equipment loads than general office areas. Separate thermal zones would facilitate the application of specific suitable energy efficiency measures for those functional spaces. 


\subsection{Advanced Building - Additional Potential Energy Measures}

Although the TSD has proposed a package of energy efficiency measures to achieve the $50 \%$ on-site energy savings goal, a number of new energy efficiency measures are worthwhile to be considered and some proposed measures can be further refined in the future. The new and refined measures have the potential to achieve the $50 \%$ goal in a more cost-effective manner or to achieve even more on-site energy savings. The following measures are suggested to be considered in future work:

- Enhanced daylight harvesting measures - Potential measures for more daylighting include the use of skylights and light tubes on the top floor, and the combined use of light shelves and daylight vertical windows to bring daylight deeper into the space.

- Advanced window shading measures for a better control of daylighting and solar energy Representative examples include electrochromic glazing and motorized blinds/shades. Such kind of measures would be especially worthwhile for consideration in climates with both hot summers and cold winters.

- Reduce window areas particularly for the east and west façades.

- Provide occupancy sensor control of HVAC setpoints and terminal unit damper positions.

- A combination of DOAS and VAV systems - Combining DOAS with VAV systems would potentially create a more cost-effective alternative than radiant systems. It needs to be mentioned that the above combined system cannot be modeled in the current version of EnergyPlus which allows only one air system for a thermal zone.

- For some climate zones with good opportunities for use of air-side economizers, allowing the outside air systems to bring in more outside air to allow more economizer benefit may be worthwhile. This would mean increasing the fan system and duct sizes of a DOAS system or designing with a VAV system with full economizer. The trade-offs for enlarging air-side economizer opportunities with increased size and cost of the ventilation system could be analyzed. Alternatively, with radiant systems, water-side economizers could be used with the addition of fluid coolers or cooling towers to the design.

- Explore alternative radiant/convective systems. Promising systems for office building include chilled ceiling panels, chilled beams and perimeter fin tubes for heating.

- Active thermal storage for higher temperature chilled water - For some climate zones with large diurnal temperature changes, it might be an effective energy measure to generate cooled water using a cooling tower at night. The cooled water can then be used at daytime for the radiant cooling system.

- The use of renewable energy sources. Potential renewable energy technologies that could be cost effective in the short term include solar thermal energy for tempering ventilation air and domestic hot water use. 


\subsection{References}

ANSI/ASHRAE. 2004. ANSI/ASHRAE Standard 62.1-2004, Ventilation for Acceptable Indoor Air Quality, American Society of Heating, Refrigerating and Air-Conditioning Engineers, Atlanta, Georgia.

ANSI/ASHRAE/IESNA. 2004a. ANSI/ASHRAE/IESNA Standard 90.1-2004, Energy Standard for Buildings Except Low-Rise Residential Buildings. American Society of Heating, Refrigerating and AirConditioning Engineers, Atlanta, Georgia.

ANSI/ASHRAE/IESNA. 2004b. User's Manual for ANSI/ASHRAE/IESNA Standard 90.1-2004, Energy Standard for Buildings Except Low-Rise Residential Buildings. American Society of Heating, Refrigerating and Air-Conditioning Engineers, Atlanta, Georgia.

ASHRAE/IESNA. 1989. ASHRAE/IESNA Standard 90.1-1989, Energy Standard for Buildings Except Low-Rise Residential Buildings. American Society of Heating, Refrigerating and Air-Conditioning Engineers, Atlanta, Georgia.

ASHRAE. 2005. Handbook of Fundamentals. American Society of Heating, Refrigerating and AirConditioning Engineers, Inc., Atlanta, Georgia, 2005.

ASHRAE. 2007. HVAC Applications Handbook, American Society of Heating, Refrigerating and AirConditioning Engineers, Inc., Atlanta, Georgia.

ASHRAE. 2009. Handbook of Fundamentals. American Society of Heating, Refrigerating and AirConditioning Engineers, Inc., Atlanta, Georgia, 2005.

Babiak, J., B.W. Olesen, and D. Petras. 2009. Low Temperature Heating and High Temperature Cooling. Federation of European Heating and Air-Conditioning Associations, Brussels, Belgium.

Briggs, R.L., R.G. Lucas, and Z.T. Taylor. 2003. Climate Classification for Building Energy Codes and Standards: Part 1—Development Process. ASHRAE Transactions, (1) pp. 4610-4611.

CBECS. 2003. Commercial Buildings Energy Consumption Survey 2003, Energy Information Administration of U.S. Department of Energy, Washington, D.C. Last accessed in July, 2009 at http://www.eia.doe.gov/emeu/cbecs/contents.html

CEC. 2009. Appliances Database - Central Air Conditioners. The California Energy Commission. Last accessed in March 2009 at http://energy.ca.gov/appliances/database/excel_based_files/Central_Air_Conditioners/

CEE. 2003. CEE Premium-efficiency Motors Initiative Efficiency Specifications. The Consortium for Energy Efficiency, Boston, Massachusetts.

DiLouie, C. 2009. CLTC Study Demonstrates Major Energy Savings for Bilevel Occupancy Sensors. Last accessed in July, 2009 at http://www.aboutlightingcontrols.org/education/papers/2009/2009_bilevel_study.shtml 
DOE. 2008. Commercial Building Benchmark Models. Last accessed in December, 2008 at http://www.eere.energy.gov/buildings/highperformance/benchmark.html

EIA. 2006. Annual Energy Review 2006. Last accessed in July, 2009 at http://www.eia.doe.gov/emeu/aer/pdf/aer.pdf

Emmerich, S.J., et al. 2005. Investigation of the Impact of Commercial Building Envelope Airtightness on HVAC Energy Use, June, 2005. National Institute of Standards and Technology, Report No. NISTIR 7238. Gaithersburg, Maryland.

EPA. 2009. ENERGY STAR Products. U.S. Environmental Protection Agency. Last accessed in March, 2009 at http://www.energystar.gov/index.cfm?fuseaction=find_a_product

Galasiu, A.D., G.R. Newsham, C. Savagau, and D.M. Sander. 2007. Energy Saving Lighting Control Systems for Open Plan Offices: A Field Study. Leukos 4 (1), pp. 7-29.

Hydeman, M., S. Taylor, J. Stein, E. Kolderup, and T. Hong. 2005. Advanced Variable Volume Air System Design Guide. Last accessed in March, 2009 at http://uccsuiouee.org/seminars/UC\%20CSU\%20VAV\%20Design\%20Guide.pdf

Jarnagin, R.E., B. Liu, D.W. Winiarski, M.F. McBride, L. Suharli, and D.Walden. 2006. Technical Support Document: Development of the Advanced Energy Design Guide for Small Office Buildings. Pacific Northwest National Laboratory, PNNL-16250. Richland, Washington.

Jarnagin, R.E., G.K. Bandyopadhyay. 2009. Determination of Weighting Factors for the ASHRAE Commercial Building Prototypes for Standard 90.1-2010 (Draft). Pacific Northwest National Laboratory. Richland, Washington.

Jeong, J.W., S.A. Mumma, and W.P. Bahnfleth. 2003. Energy conservation benefits of a dedicated outdoor air system with parallel sensible cooling by ceiling radiant panels. ASHRAE Transactions 109 (2), pp. 627-636.

Jiang W., R.E. Jarnagin, K. Gowri, M.F. McBride, and L. Bing. 2008. Technical Support Document: Development of the Advanced Energy Design Guide for Highway Lodging Buildings. Pacific Northwest National Laboratory, Richland, Washington.

Konopacki, S., and H. Akbari. 2001. Measured Energy Savings and Demand Reduction form a Reflective Roof Membrane on a Large Retail Store in Austin. Technical Report LBNL-47149, Lawrence Berkeley National Laboratory, Berkeley, California.

LBNL. 2009. Cool Roofing Materials Database. Lawrence Berkley Laboratory, California. Last accessed in March 2009 at http://eetd.lbl.gov/coolroofs/

Liu, B., R.E. Jarnagin, D.W. Winiarski, W. Jiang, M.F. McBride and and G.C. Crall. 2006. Technical Support Document: Development of the Advanced Energy Design Guide for Small Retail Buildings. Pacific Northwest National Laboratory, PNNL-16031. Richland, Washington. 
Liu, B., R.E. Jarnagin, W. Jiang, and K. Gowri. 2007. Technical Support Document: Development of the Advanced Energy Design Guide for Small Warehouse and Self-storage Buildings. Pacific Northwest National Laboratory, PNNL-17056, Richland, Washington.

LRC. 2004. Reducing Barriers to Use of High Efficiency lighting. Final Report Year 3. Lighting Research Center, Rensselaer Polytechnic Institute, Troy, New York.

McDowell, T.P., and S.J. Emmerich. 2005. Analysis of Dedicated Outdoor Air Systems for Different Climates.” Proceedings of the $9^{\text {th }}$ IBPSA Conference, Montreal, Canada, pp. 733-740.

Mumma, S.A. 2001. Designing Dedicated Outdoor Air Systems. ASHRAE Journal 43 (5), pp. 28-31.

Mumma, S.A., and K.M. Shank. 2001. Achieving Dry Outside Air in an Energy-Efficient Manner. ASHRAE Transactions 107 (1), pp. 553-561.

NBI. 2008. Buildings Database. New Building Institute, White Salmon, WA. Last accessed in December, 2008 http://www.gettingtofifty.org/buildings.htm

Olesen, B. 2002. Radiant Floor Heating in Theory and Practice. ASHRAE Journal 44 (7), pp. 19-24.

Olesen, B. 2008. Radiant Floor Cooling Systems. ASHRAE Journal 50 (9), pp. 16-22.

Pless, S., P. Torcellini, and N. Long. 2007. Technical Support Document: Development of the Advanced Energy Design Guide for K-12 Schools-30\% Energy Savings. National Renewable Energy Laboratory. NREL/TP-550-42114. Golden, CO.

PNNL. 2004. Technical Support Document: Energy Efficiency Program for Commercial and Industrial Equipment: Advanced Notice of Proposed Rulemaking for Commercial Unitary Air Conditioners and Heat Pumps, July, 2004. U.S. Department of Energy (http://www.eere.energy.gov/buildings/appliance_standards/commercial/pdfs/cuac_tsd_chp_6.pdf)

Richman, E. 2008. Survey from 4 lighting designers on 90.1 lighting sub-committee in 2008. Pacific Northwest National Laboratory.

Richman, E.E., E. Rauch, J. Knappek, J. Phillips, K. Petty and P. Lopez-Rangel. 2008. National Commercial Construction Characteristics and Compliance with Building Energy Codes: 1999-2007. 2008 ACEEE Summery Study on Energy Efficiency in Buildings, Pacific Grove, California.

Rivas, J., 2009, Managing Plug Loads, E-Source slides, February 19, 2009.

RS Means. 2009. Building Cost Data. Kingston, Massachusetts.

Sanchez, M., C. Webber, R. Brown, J. Busch, M. Pinckard, and J. Roberson. 2007. Space Heaters, Computers, Cell Phone Chargers: How Plugged In Are Commercial Buildings? LBNL-62397. Lawrence Berkeley National Laboratory, Berkeley, California.

Swami, H.V. and S. Chandra. 1987. Procedures for calculating natural ventilation airflow rates in buildings. Final Report FSEC-CR-163-86. Florida Solar Energy Center, Cape Canaveral. 
Village of Wheeling. 2009. Parking Space Requirements. Last Accessed in March 2009 at http://www.vi.wheeling.il.us/Services/CommunityDevelopment/Planning/ParkingSpaceRequirements.htm

VonNeida, B., D. Maniccia, and T. Allan. 2000. An Analysis of the Energy and Cost Savings Potential of Occupacy Sensors for Commercial Lighting Systems. Last accessed in February 2009 at www.lrc.rpi.edu/resources/pdf/.

Wassmer, M., and M. J. Brandemuehl. 2006. Effect of Data Availability on Modeling of Residential Air Conditioners and Heat Pumps for Energy Calculations. ASHRAE Transactions 111(1), pp. 214-225. 
Appendix A

\section{Energy Modeling Input Assumptions}


Table A.1.a. Baseline and Advanced Buildings Model Assumptions for Medium Office Building Prototype (53,600 ft $\left.{ }^{2}\right) \mathrm{IP}_{\mathrm{units}}$

\begin{tabular}{|c|c|c|c|c|}
\hline Characteristic & Baseline & Advanced-Radiant & Advanced-VAV & Data Source/Remarks \\
\hline \multicolumn{5}{|c|}{ ARCHITECTURALL FEATURES } \\
\hline \multicolumn{5}{|l|}{ Exterior Walls } \\
\hline Construction & $\begin{array}{l}\text { Steel-framed wall } \\
\text { - 0.75-in stucco } \\
\text { - 0.625-in gypsum board } \\
\text { - 2x4 @ 16-in O.C. stud with } \\
\text { fiberglass insulation in cavity } \\
\text { - rigid board insulation } \\
\text { - } 0.625 \text {-in gypsum board }\end{array}$ & Same as baseline & Same as baseline & CBECS 2003 \\
\hline $\begin{array}{l}\text { Overall U-factor } \\
\left(\mathrm{Btu} / \mathrm{h} \cdot \mathrm{ft}^{2} \cdot \mathrm{F}\right)\end{array}$ & $\begin{array}{l}\text { Zones 1-4: } 0.124 \\
\text { Zones 5- 6: } 0.084 \\
\text { Zones 7-8: } 0.064\end{array}$ & $\begin{array}{l}\text { Zones 1-4: } 0.064 \\
\text { Zone 5: } 0.042 \\
\text { Zones 6-8: } 0.037\end{array}$ & Same as Radiant & $\begin{array}{l}\text { ASHRAE 90.1-2004 } \\
\text { Addendum bb to ASHRAE } \\
\text { 90.1-2007 (review draft) }\end{array}$ \\
\hline \multicolumn{5}{|l|}{ Roof } \\
\hline Construction & $\begin{array}{l}\text { Flat roof with insulation entirely } \\
\text { above deck } \\
\text { - roof membrane } \\
\text { - continuous rigid insulation } \\
\text { - metal deck }\end{array}$ & Same as baseline & Same as baseline & CBECS 2003 \\
\hline $\begin{array}{l}\text { Overall U-factor } \\
\left(\mathrm{Btu} / \mathrm{h} \cdot \mathrm{ft}^{2} \cdot \mathrm{F}\right)\end{array}$ & $\begin{array}{l}\text { Zones 1-7: } 0.063 \\
\text { Zone 8: } 0.048\end{array}$ & $\begin{array}{l}\text { Zone 1: } 0.048 \\
\text { Zones 2- 3: } 0.039 \\
\text { Zones 4-6: } 0.032 \\
\text { Zones 7-8: } 0.028\end{array}$ & Same as for Radiant & $\begin{array}{l}\text { ASHRAE 90.1-2004 } \\
\text { Addendum bb to ASHRAE } \\
\text { 90.1-2007 (review draft) }\end{array}$ \\
\hline Solar Reflectance & 0.23 & $\begin{array}{l}\text { Zones 1-3: } 0.69 \text { (white EPDM) } \\
\text { Zones 4-8: } 0.23\end{array}$ & Same as for Radiant & $\begin{array}{l}\text { LBNL 2009: } \\
\text { http://eetd.lbl.gov/coolroofs/ }\end{array}$ \\
\hline \multicolumn{5}{|c|}{ Slab-on-Grade Floor } \\
\hline Construction & $\begin{array}{l}\text { Concrete slab on earth } \\
\text { - carpet pad } \\
\text { - } 6 \text {-in concrete }\end{array}$ & $\begin{array}{l}\text { Fully insulated slab } \\
\text { - } 2 \text {-in screed } \\
\text { - } \text { rigid insulation (1.5-in EPS } \\
\quad \text { for Zones 3A, 4A, 5A, 7, and } \\
\text { 8; } 1 \text {-in EPS for other zones) } \\
\text { - } 6 \text {-in concrete }\end{array}$ & Same as baseline & $\begin{array}{l}\text { ASHRAE 90.1-2004 } \\
\text { Jan et al, } 2009\end{array}$ \\
\hline
\end{tabular}


Table A.1.a. IP units (continued)

\begin{tabular}{|c|c|c|c|c|}
\hline Characteristic & Baseline & Advanced-Radiant & Advanced-VAV & Data Source/Remarks \\
\hline $\begin{array}{l}\text { Floor F-factor } \\
(\mathrm{Btu} / \mathrm{h} \cdot \mathrm{ft} \cdot \mathrm{F})\end{array}$ & $\begin{array}{l}\text { Zones 1-7: } 0.730 \\
\text { Zone 8: } 0.540\end{array}$ & $\begin{array}{l}\text { Zones 3A, 4A, 5A, 7, 8: } 0.55 \\
\text { Other zones: } 0.64\end{array}$ & $\begin{array}{l}\text { Zones 1-3: } 0.730 \\
\text { Zones 4-5: } 0.520 \\
\text { Zones 6-7: } 0.510 \\
\text { Zone 8: } 0.434\end{array}$ & $\begin{array}{l}\text { ASHRAE 90.1-2004 } \\
\text { Addendum bb to ASHRAE } \\
\text { 90.1-2007 (review draft) }\end{array}$ \\
\hline \multicolumn{5}{|l|}{ Fenestration } \\
\hline Window wall ratio & 0.33 for all facades & 0.33 for all facades & 0.33 for all facades & CBECS 2003 \\
\hline $\begin{array}{l}\text { Targeted U- } \\
\text { factor/SHGC }\end{array}$ & $\begin{array}{l}\text { Zones } 1-2: 1.22 / 0.25 \\
\text { Zones 3A, 3B: } 0.57 / 0.25 \\
\text { Zone 3C: } 1.22 / 0.34 \\
\text { Zones 4-6: } 0.57 / 0.39 \\
\text { Zone 7: } 0.57 / 0.49 \\
\text { Zone 8: } 0.46 / \mathrm{NR}\end{array}$ & $\begin{array}{l}\text { Zones 1-2: } 0.65 / 0.25 \\
\text { Zone 3: } 0.60 / 0.25 \\
\text { Zones 4-5: } 0.44 / 0.26 \\
\text { Zone 6: } 0.42 / 0.35 \\
\text { Zones } 7-8: 0.34 / 0.40\end{array}$ & $\begin{array}{l}\text { Zones } 1-2: 0.65 / 0.25 \\
\text { Zone 3: 0.60/0.25 } \\
\text { Zones 4-6: } 0.39 / 0.38 \\
\text { Zone } 7-8: 0.34 / 0.4\end{array}$ & $\begin{array}{l}\text { ASHRAE 90.1-2004 } \\
\text { Addendum bb to ASHRAE } \\
\text { 90.1-2007 (review draft) }\end{array}$ \\
\hline $\begin{array}{l}\text { Actual selected } \\
\text { window U- } \\
\text { factor/SHGC/VLT }\end{array}$ & $\begin{array}{l}\text { Zones } 1-2: 1.08 / 0.28 / 0.16 \\
\text { Zones 3A, 3B: } 0.51 / 0.28 / 0.20 \\
\text { Zone 3C: } 0.94 / 0.34 / 0.22 \\
\text { Zones 4-6: } 0.55 / 0.43 / 0.41 \\
\text { Zone } 7: 0.55 / 0.50 / 0.51 \\
\text { Zone 8: } 0.48 / 0.47 / 0.38\end{array}$ & $\begin{array}{l}\text { Zones 1-3: } 0.51 / 0.28 / 0.20 \\
\text { Zones 4-5: } 0.44 / 0.24 / 0.16 \\
\text { Zone 6: } 0.42 / 0.39 / 0.44 \\
\text { Zones 7-8: } 0.31 / 0.38 / 0.44\end{array}$ & $\begin{array}{l}\text { Zones 1-3: } 0.51 / 0.28 / 0.20 \\
\text { Zones 4-6: } 0.42 / 0.39 / 0.44 \\
\text { Zones 7-8: } 0.31 / 0.38 / 0.44\end{array}$ & $\begin{array}{l}\text { Window type chosen from } \\
\text { EnergyPlus Library with the } \\
\text { closest matching U- } \\
\text { factor/SHGC }\end{array}$ \\
\hline Exterior shading & No & $\begin{array}{l}\text { Overhang with a project factor } \\
\text { of } 0.5 \text { for zones } 1-5 \text {; no } \\
\text { overhang for other zones }\end{array}$ & Same as for Radiant & $\begin{array}{l}\text { AEDG 30pct guides (e.g., } \\
\text { Jarnagin et al., 2006) }\end{array}$ \\
\hline Interior shading & No & No & No & \\
\hline \multicolumn{5}{|c|}{ INTERNAL LOADS } \\
\hline \multicolumn{5}{|l|}{ Occupancy } \\
\hline $\begin{array}{l}\text { Occupant density } \\
\text { (person/1000 } \mathrm{ft}^{2} \text { ) }\end{array}$ & 5 & 5 & 5 & ASHRAE 62.1-2004 \\
\hline Schedule & See Table A.2 & Same as baseline & Same as baseline & \\
\hline $\begin{array}{l}\text { Radiant/Convective } \\
\text { fractions of sensible } \\
\text { loads }\end{array}$ & $0.3 / 0.7$ & $0.3 / 0.7$ & $0.3 / 0.7$ & $\begin{array}{l}\text { ASHRAE Fundamentals } \\
\text { Handbook }\end{array}$ \\
\hline
\end{tabular}


Table A.1.a. IP units (continued)

\begin{tabular}{|c|c|c|c|c|}
\hline Characteristic & Baseline & Advanced-Radiant & Advanced-VAV & Data Source/Remarks \\
\hline \multicolumn{5}{|l|}{ Lighting } \\
\hline $\begin{array}{l}\text { Peak lighting power } \\
\text { density }\left(\mathrm{W} / \mathrm{ft}^{2}\right)\end{array}$ & 1.0 & 0.75 & 0.75 & $\begin{array}{l}\text { ASHRAE 90.1-2004 } \\
\text { Lighting design and } \\
\text { calculation (see TSD Section } \\
\text { 4.2) }\end{array}$ \\
\hline Occupancy sensors & $\begin{array}{l}\text { Used in conference and lounge } \\
\text { area }\end{array}$ & $\begin{array}{l}\text { Used in conference room, } \\
\text { lounge, offices, storage, } \\
\text { restrooms, and mechanical } \\
\text { room }\end{array}$ & Same as for Radiant & \\
\hline Daylight harvesting & No & $\begin{array}{l}\text { - Continuous dimming } \\
\text { - Illuminance setpoint: } 300 \text { lux } \\
\text { - Minimum input power } \\
\text { fraction: } 0.1 \\
\text { - Minimum light output } \\
\text { fraction: } 0.2\end{array}$ & Same as for Radiant & \\
\hline Schedule & See Table A.2 & See Table A.3 & See Table A.3 & \\
\hline \multicolumn{5}{|l|}{ Plug load } \\
\hline $\begin{array}{l}\text { Peak plug-load } \\
\text { power density } \\
\left(\mathrm{W} / \mathrm{ft}^{2}\right)\end{array}$ & 0.75 & 0.55 & 0.55 & $\begin{array}{l}\text { Plug-load calculation in } \\
\text { TSD sections 3.5.4 and } 4.3\end{array}$ \\
\hline Schedule & See Table A. 2 & See Table A.3 & See Table A.3 & \\
\hline \multicolumn{5}{|l|}{ Elevator } \\
\hline Power (W) & 32780 & 32780 & 32780 & \\
\hline Schedule & See Table A.2 & Same as baseline & Same as baseline & \\
\hline
\end{tabular}


Table A.1.a. IP units (continued)

\begin{tabular}{|c|c|c|c|c|}
\hline Characteristic & Baseline & Advanced-Radiant & Advanced-VAV & Data Source/Remarks \\
\hline \multicolumn{5}{|c|}{ HVAC SYSTEM } \\
\hline \multicolumn{5}{|l|}{ System type } \\
\hline Heating/Cooling & $\begin{array}{l}\text { Packaged VAV system } \\
\text { - DX packaged air conditioning } \\
\text { unit for cooling } \\
\text { - gas furnace for heating }\end{array}$ & $\begin{array}{l}\text { Radiant floor heating and } \\
\text { cooling + DOAS } \\
\text { - air-cooled chiller for radiant } \\
\text { cooling } \\
\text { - condensing boiler for radiant } \\
\text { heating } \\
\text { - DOAS unit with DX coil for } \\
\text { cooling /dehumidification } \\
\text { and hot-water coil for } \\
\text { reheating }\end{array}$ & $\begin{array}{l}\text { Packaged VAV system } \\
\text { - DX packaged air } \\
\text { conditioning unit for } \\
\text { cooling } \\
\text { - gas furnace for heating } \\
\text { - indirect evaporative } \\
\text { cooler for precooling in } \\
\text { climate zones 2B, 3B, } \\
\text { 4B and 5B. }\end{array}$ & CBECS 2003 \\
\hline \multicolumn{5}{|l|}{ HVAC efficiency } \\
\hline Cooling efficiency & $\begin{array}{l}\text { DX cooling coil } \\
\text { - EER=9.0-10.1, depending on } \\
\text { the sized capacity } \\
\text { - performance curves see Table } \\
\text { A.4 }\end{array}$ & $\begin{array}{l}\text { Air cooled chiller } \\
\text { - COP=3.1 } \\
\text { - Chiller performance curves } \\
\text { see Table A.5 } \\
\text { DX coil in the DOAS unit } \\
\text { - EER }=11.3 \text { or } 11.5 \text {, } \\
\text { depending on the sized } \\
\text { capacity } \\
\text { - DOAS DX performance } \\
\text { curves see Table A.6 }\end{array}$ & $\begin{array}{l}\text { DX cooling coil } \\
\text { - EER=10.2-11.5, } \\
\text { depending on the sized } \\
\text { capacity } \\
\text { - performance curves see } \\
\text { Table A. } 4 \\
\text { Indirect evaporative cooler } \\
\text { - effectiveness: } 0.7 \\
\text { - pressure drop: } 0.8 \text { in. } \\
\text { w.c. }\end{array}$ & $\begin{array}{l}\text { ASHRAE 90.1-2004 } \\
\text { ASHRAE 90.1-2007 } \\
\text { Appliances database of } \\
\text { California Energy } \\
\text { Commission. } \\
\text { Manufactures' Catalog }\end{array}$ \\
\hline Heating efficiency & $\begin{array}{l}\text { Gas furnace } \\
\text { - } \text { burner efficiency }=0.78 \\
\quad \text { (capacity<=225 kBtu/h); } \\
=0.80 \text { (capacity }>225 \mathrm{kBtu} / \mathrm{h}) \\
\text { - part load performance curve } \\
\text { see Table A.7 }\end{array}$ & $\begin{array}{l}\text { Condensing boiler } \\
\text { Thermal efficiency }=0.95\end{array}$ & Same as baseline & $\begin{array}{l}\text { ASHRAE 90.1-2004 } \\
\text { ASHRAE 90.1-2007 }\end{array}$ \\
\hline
\end{tabular}


Table A.1.a. IP units (continued)

\begin{tabular}{|c|c|c|c|c|}
\hline Characteristic & Baseline & Advanced-Radiant & Advanced-VAV & Data Source/Remarks \\
\hline \multicolumn{5}{|l|}{ HVAC control } \\
\hline $\begin{array}{l}\text { Thermostat setpoint } \\
\left({ }^{\circ} \mathrm{F}\right)\end{array}$ & 75 cooling/ 70 heating & 75 cooling/ 67 heating & 75 cooling/ 70 heating & $\begin{array}{l}\text { Design practice } \\
\text { Jan et al. } 2009\end{array}$ \\
\hline $\begin{array}{l}\text { Thermostat setup / } \\
\text { setback }\left({ }^{\circ} \mathrm{F}\right)\end{array}$ & 80 cooling / 65 heating & 80 cooling / 65 heating & 80 cooling / 65 heating & Design practice \\
\hline $\begin{array}{l}\text { Plant loop } \\
\text { temperature control }\end{array}$ & NA & $\begin{array}{l}-59^{\circ} \mathrm{F} \text { for chilled water } \\
-113^{\circ} \mathrm{F} \text { for hot water }\end{array}$ & NA & $\begin{array}{l}\text { Design practice } \\
\text { Jan et al. } 2009\end{array}$ \\
\hline Air system & $\begin{array}{l}\text { - Supply air temperature: } 55^{\circ} \mathrm{F} \\
\text { - No supply air temperature } \\
\text { reset }\end{array}$ & $\begin{array}{l}\text { - Supply air temperature: } 55^{\circ} \mathrm{F} \\
\text { - Supply air temperature reset } \\
\text { based on outside air } \\
\text { temperature (except climate } \\
\text { zones } 1-3 \text { ) }\end{array}$ & $\begin{array}{l}\text { - Supply air temperature: } \\
55^{\circ} \mathrm{F} \\
\text { - Supply air temperature } \\
\text { reset based on the } \\
\text { warmest thermal zone } \\
\text { (except climate zones } \\
\text { 1A, 2A, 3A and 4A) }\end{array}$ & \\
\hline $\begin{array}{l}\text { Hydronic radiant } \\
\text { system }\end{array}$ & NA & $\begin{array}{l}\text { - Variable flow based on mean } \\
\text { air temperature } \\
\text { - Temperature throttling } \\
\text { range: } 2^{\circ} \mathrm{C} \\
\text { - Radiant heating and cooling } \\
\text { setpoints see Figure } 4.6\end{array}$ & NA & \\
\hline \multicolumn{5}{|l|}{ Ventilation } \\
\hline Damper control & $\begin{array}{l}\text { Gravity damper is used for } \\
\text { climate zones 1-3; motorized } \\
\text { damper for other zones }\end{array}$ & $\begin{array}{l}\text { Motorized damper is used for } \\
\text { all climate zones }\end{array}$ & $\begin{array}{l}\text { Motorized damper is used } \\
\text { for all climate zones }\end{array}$ & ASHRAE 90.1-2004 \\
\hline $\begin{array}{l}\text { Demand controlled } \\
\text { ventilation }\end{array}$ & No & Yes & Yes & \\
\hline
\end{tabular}


Table A.1.a. IP units (continued)

\begin{tabular}{|c|c|c|c|c|}
\hline Characteristic & Baseline & Advanced-Radiant & Advanced-VAV & Data Source/Remarks \\
\hline Energy recovery & No & $\begin{array}{l}\text { - Rotary heat exchanger is } \\
\text { used for energy recovery in } \\
\text { all climate zones except 3B- } \\
\text { CA and } 3 \mathrm{C} \text {. } \\
\text { - Heat recovery effectiveness } \\
\text { see Table } 4.10 \\
\text { - Frost control based on } \\
\text { minimum exhaust temperature } \\
\text { at } 35^{\circ} \mathrm{F}\end{array}$ & $\begin{array}{l}\text { - Rotary heat exchanger is } \\
\text { used for energy recovery } \\
\text { in all climate zones } \\
\text { except 3B and 3C. } \\
\text { - Heat recovery } \\
\text { effectiveness see } \\
\text { Table4.10 } \\
\text { - Frost control based on } \\
\text { minimum exhaust } \\
\text { temperature at } 35^{\circ} \mathrm{F}\end{array}$ & \\
\hline Economizer & $\begin{array}{l}\text { No economizer is used in } \\
\text { climate zones } 1 \mathrm{~A}, 2 \mathrm{~A}, 3 \mathrm{~A} \text { and } \\
4 \mathrm{~A} \text {; differential drybulb based } \\
\text { economizer is used for all other } \\
\text { zones. }\end{array}$ & No economizer for DOAS & $\begin{array}{l}\text { Differential enthalpy based } \\
\text { economizer is used in } \\
\text { climate zones } 1 \mathrm{~A}, 2 \mathrm{~A}, 3 \mathrm{~A} \\
\text { and } 4 \mathrm{~A} \text {; differential } \\
\text { drybulb based economizer } \\
\text { is used for all other zones. }\end{array}$ & ASHRAE 90.1-2004 \\
\hline \multicolumn{5}{|l|}{ Fan System } \\
\hline Supply fan & $\begin{array}{l}\text { - Variable speed fan } \\
\text { - Fan mechanical efficiency: } \\
65 \% \\
\text { - Fan motor efficiency based on } \\
\text { motor power (See Table 4.12) } \\
\text { - Part-load performance curve } \\
\text { see Table A.8 }\end{array}$ & $\begin{array}{l}\text { - Constant speed fan for the } \\
\text { DOAS } \\
\text { - Fan mechanical efficiency: } \\
65 \% \\
\text { - Fan motor efficiency based } \\
\text { on motor power (See Table } \\
4.12 \text { ) }\end{array}$ & $\begin{array}{l}\text { - Variable speed fan } \\
\text { - Fan mechanical } \\
\text { efficiency: 65\% } \\
\text { - Fan motor efficiency } \\
\text { based on motor power } \\
\text { (See Table } 4.12 \text { ) } \\
\text { - Part-load performance } \\
\text { curve see Table A.6 }\end{array}$ & \\
\hline Exhaust/return fan & Not explicitly modeled. & Same as baseline & Same as baseline & \\
\hline $\begin{array}{l}\text { Fan system static } \\
\text { pressure }\end{array}$ & 6.32 in. w.c & $\begin{array}{l}\text { - } 2.5 \text { in. w.c. } \\
\text { - } \text { Additional } 1.5 \text { in w.c } \\
\text { pressure drop for ERV. }\end{array}$ & $\begin{array}{l}\text { - If supply air CFM < } \\
\text { 4648, the static pressure } \\
\text { is } 3.4 \text { in. w.c.; } \\
\text { otherwise, the pressure } \\
4.98 . \\
\text { - } \text { Additional } 1.5 \text { in. w.c. } \\
\text { pressure if ERV is used. } \\
\text { - Additional } 0.8 \text { in. w.c. } \\
\text { pressure if evaporative } \\
\text { cooling is used. }\end{array}$ & $\begin{array}{l}\text { Derived from fan power } \\
\text { limitation in ASHRAE 90.1- } \\
2004\end{array}$ \\
\hline
\end{tabular}


Table A.1.a. IP units (continued)

\begin{tabular}{|c|c|c|c|c|}
\hline Characteristic & Baseline & Advanced-Radiant & Advanced-VAV & Data Source/Remarks \\
\hline \multicolumn{5}{|c|}{ SERVICE WATER HEATING } \\
\hline $\begin{array}{l}\text { Gas-fired water } \\
\text { heater }\end{array}$ & $\begin{array}{l}\text { - Conventional type with } \\
\text { thermal efficiency }=80 \% \\
\text { - Tank volume }=200 \text { gallon } \\
\text { - Standby heat loss coefficient } \\
=15.414 \text { Btu } / \mathrm{hr}-{ }^{\circ} \mathrm{F}\end{array}$ & $\begin{array}{l}\text { - Condensing water heater } \\
\text { with thermal efficiency }= \\
95 \% \text {. } \\
\text { - Tank volume }=200 \text { gallon } \\
\text { - Standby heat loss coefficient } \\
=15.414 \text { Btu/hr- }{ }^{\circ} \mathrm{F}\end{array}$ & Same as for Radiant & $\begin{array}{l}\text { ASHRAE 90.1-2004 } \\
\text { Manufacturers' Catalog }\end{array}$ \\
\hline
\end{tabular}


Table A.2.b. Baseline and Advanced Buildings Model Assumptions for Medium Office Building Prototype (4,379 m²) SI units

\begin{tabular}{|c|c|c|c|c|}
\hline Characteristic & Baseline & Advanced-Radiant & Advanced-VAV & Data Source/Remarks \\
\hline \multicolumn{5}{|c|}{ ARCHITECTURALL FEATURES } \\
\hline \multicolumn{5}{|l|}{ Exterior Walls } \\
\hline Construction & 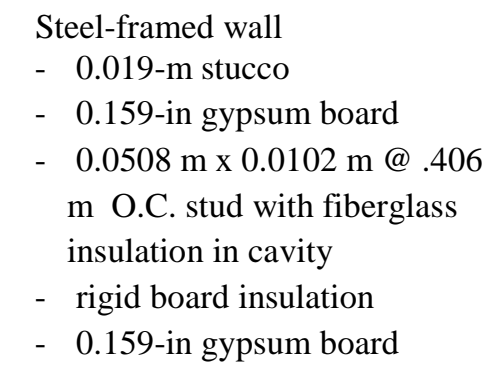 & Same as baseline & Same as baseline & CBECS 2003 \\
\hline $\begin{array}{l}\text { Overall U-factor } \\
\text { (W/m2-K) }\end{array}$ & $\begin{array}{l}\text { Zones 1-4: } 0.704 \\
\text { Zones 5- 6: } 0 . .477 \\
\text { Zones 7-8: } 0.363\end{array}$ & $\begin{array}{l}\text { Zones 1-4: } 0 . .363 \\
\text { Zone 5: } 0.238 \\
\text { Zones 6-8: } 0.210\end{array}$ & Same as Radiant & $\begin{array}{l}\text { ASHRAE 90.1-2004 } \\
\text { Addendum bb to ASHRAE } \\
\text { 90.1-2007 (review draft) }\end{array}$ \\
\hline \multicolumn{5}{|l|}{ Roof } \\
\hline Construction & $\begin{array}{l}\text { Flat roof with insulation entirely } \\
\text { above deck } \\
\text { - roof membrane } \\
\text { - continuous rigid insulation } \\
\text { - metal deck }\end{array}$ & Same as baseline & Same as baseline & CBECS 2003 \\
\hline $\begin{array}{l}\text { Overall U-factor } \\
(\mathrm{W} / \mathrm{m} 2-\mathrm{K})\end{array}$ & $\begin{array}{l}\text { Zones 1-7: } 0.358 \\
\text { Zone 8: } 0.273\end{array}$ & $\begin{array}{l}\text { Zone 1: } 0.273 \\
\text { Zones 2- 3: } 0.221 \\
\text { Zones 4-6: } 0.182 \\
\text { Zones 7-8: } 0.159\end{array}$ & Same as for Radiant & $\begin{array}{l}\text { ASHRAE 90.1-2004 } \\
\text { Addendum bb to ASHRAE } \\
\text { 90.1-2007 (review draft) }\end{array}$ \\
\hline Solar Reflectance & 0.23 & $\begin{array}{l}\text { Zones 1-3: } 0.69 \text { (white EPDM) } \\
\text { Zones 4-8: } 0.23\end{array}$ & Same as for Radiant & $\begin{array}{l}\text { LBNL 2009: } \\
\text { http://eetd.lbl.gov/coolroofs/ }\end{array}$ \\
\hline \multicolumn{5}{|c|}{ Slab-on-Grade Floor } \\
\hline Construction & $\begin{array}{l}\text { Concrete slab on earth } \\
\text { - carpet pad } \\
\text { - } 0.152-m \text { concrete }\end{array}$ & $\begin{array}{l}\text { Fully insulated slab } \\
\text { - } 0.508-m \text { screed } \\
\text { - } \quad \text { rigid insulation (.0381-m EPS } \\
\text { for Zones 3A, 4A, 5A, 7, and 8; } \\
\text { 0.0254-m EPS for other zones) } \\
\quad \text { - } 0.152-m \text { concrete }\end{array}$ & Same as baseline & $\begin{array}{l}\text { ASHRAE 90.1-2004 } \\
\text { Jan et al, } 2009\end{array}$ \\
\hline
\end{tabular}


Table A.1.b. SI Units (continued)

\begin{tabular}{|c|c|c|c|c|}
\hline Characteristic & Baseline & Advanced-Radiant & Advanced-VAV & Data Source/Remarks \\
\hline $\begin{array}{l}\text { Floor F-factor } \\
(\mathrm{W} / \mathrm{m} \cdot \mathrm{K})\end{array}$ & $\begin{array}{l}\text { Zones 1-7: } 1.26 \\
\text { Zone 8: } 0.930\end{array}$ & $\begin{array}{l}\text { Zones 3A, 4A, 5A, 7, 8: } 0.952 \\
\text { Other zones: } 1.11\end{array}$ & $\begin{array}{l}\text { Zones 1-3: } 1.26 \\
\text { Zones 4-5: } 0.900 \\
\text { Zones 6-7: } 0.883 \\
\text { Zone 8: } 0.751\end{array}$ & $\begin{array}{l}\text { ASHRAE 90.1-2004 } \\
\text { Addendum bb to ASHRAE } \\
\text { 90.1-2007 (review draft) }\end{array}$ \\
\hline \multicolumn{5}{|l|}{ Fenestration } \\
\hline Window wall ratio & 0.33 for all facades & 0.33 for all facades & 0.33 for all facades & CBECS 2003 \\
\hline $\begin{array}{l}\text { Targeted U- } \\
\text { factor/SHGC }\end{array}$ & $\begin{array}{l}\text { Zones } 1-2: 6.93 / 0.25 \\
\text { Zones 3A, 3B: 3.2/0.25 } \\
\text { Zone 3C: } 6.93 / 0.34 \\
\text { Zones 4-6: 3.2/0.39 } \\
\text { Zone 7: 3.2/0.49 } \\
\text { Zone 8: } 2.6 / \mathrm{NR}\end{array}$ & $\begin{array}{l}\text { Zones } 1-2: 3.7 / 0.25 \\
\text { Zone 3: } 3.4 / 0.25 \\
\text { Zones } 4-5: 2.5 / 0.26 \\
\text { Zone 6: } 2.4 / 0.35 \\
\text { Zones } 7-8: 1.9 / 0.40\end{array}$ & $\begin{array}{l}\text { Zones } 1-2: 3.7 / 0.25 \\
\text { Zone 3: 3.4/0.25 } \\
\text { Zones 4-6: } 2.2 / 0.38 \\
\text { Zone } 7-8: 1.9 / 0.4\end{array}$ & $\begin{array}{l}\text { ASHRAE 90.1-2004 } \\
\text { Addendum bb to ASHRAE } \\
\text { 90.1-2007 (review draft) }\end{array}$ \\
\hline $\begin{array}{l}\text { Actual selected } \\
\text { window U- } \\
\text { factor/SHGC/VLT }\end{array}$ & $\begin{array}{l}\text { Zones } 1-2: 6.13 / 0.28 / 0.16 \\
\text { Zones 3A, 3B: } 2.9 / 0.28 / 0.20 \\
\text { Zone 3C: 5.3/0.34/0.22 } \\
\text { Zones 4-6: 3.1/0.43/0.41 } \\
\text { Zone 7: 3.1/0.50/0.51 } \\
\text { Zone 8: 2.7/0.47/0.38 }\end{array}$ & $\begin{array}{l}\text { Zones 1-3: 2.9/0.28/0.20 } \\
\text { Zones 4-5: 2.5/0.24/0.16 } \\
\text { Zone 6: } 2.4 / 0.39 / 0.44 \\
\text { Zones 7-8: } 1.8 / 0.38 / 0.44\end{array}$ & $\begin{array}{l}\text { Zones 1-3: } 2.9 / 0.28 / 0.20 \\
\text { Zones 4-6: } 2.4 / 0.39 / 0.44 \\
\text { Zones 7-8: } 1.8 / 0.38 / 0.44\end{array}$ & $\begin{array}{l}\text { Window type chosen from } \\
\text { EnergyPlus Library with the } \\
\text { closest matching U- } \\
\text { factor/SHGC }\end{array}$ \\
\hline Exterior shading & No & $\begin{array}{l}\text { Overhang with a project factor } \\
\text { of } 0.5 \text { for zones } 1-5 \text {; no } \\
\text { overhang for other zones }\end{array}$ & Same as for Radiant & $\begin{array}{l}\text { AEDG 30pct guides (e.g., } \\
\text { Jarnagin et al., 2006) }\end{array}$ \\
\hline Interior shading & No & No & No & \\
\hline \multicolumn{5}{|c|}{ INTERNAL LOADS } \\
\hline \multicolumn{5}{|l|}{ Occupancy } \\
\hline $\begin{array}{l}\text { Occupant density } \\
\text { (person/92.9 m²) }\end{array}$ & 5 & 5 & 5 & ASHRAE 62.1-2004 \\
\hline Schedule & See Table A.2 & Same as baseline & Same as baseline & \\
\hline $\begin{array}{l}\text { Radiant/Convective } \\
\text { fractions of sensible } \\
\text { loads }\end{array}$ & $0.3 / 0.7$ & $0.3 / 0.7$ & $0.3 / 0.7$ & $\begin{array}{l}\text { ASHRAE Fundamentals } \\
\text { Handbook }\end{array}$ \\
\hline
\end{tabular}


Table A.1.b. SI Units (continued)

\begin{tabular}{|c|c|c|c|c|}
\hline Characteristic & Baseline & Advanced-Radiant & Advanced-VAV & Data Source/Remarks \\
\hline \multicolumn{5}{|l|}{ Lighting } \\
\hline $\begin{array}{l}\text { Peak lighting power } \\
\text { density }\left(\mathrm{W} / \mathrm{ft}^{2}\right)\end{array}$ & 10.76 & 8.07 & 8.07 & $\begin{array}{l}\text { ASHRAE 90.1-2004 } \\
\text { Lighting design and } \\
\text { calculation (see TSD Section } \\
4.2 \text { ) }\end{array}$ \\
\hline Occupancy sensors & $\begin{array}{l}\text { Used in conference and lounge } \\
\text { area }\end{array}$ & $\begin{array}{l}\text { Used in conference room, } \\
\text { lounge, offices, storage, } \\
\text { restrooms, and mechanical } \\
\text { room }\end{array}$ & Same as for Radiant & \\
\hline Daylight harvesting & No & $\begin{array}{l}\text { - Continuous dimming } \\
\text { - Illuminance setpoint: } 300 \text { lux } \\
\text { - Minimum input power } \\
\text { fraction: } 0.1 \\
\text { - Minimum light output } \\
\text { fraction: } 0.2\end{array}$ & Same as for Radiant & \\
\hline Schedule & See Table A. 2 & See Table A.3 & See Table A.3 & \\
\hline \multicolumn{5}{|l|}{ Plug load } \\
\hline $\begin{array}{l}\text { Peak plug-load } \\
\text { power density } \\
\left(\mathrm{W} / \mathrm{ft}^{2}\right)\end{array}$ & 8.07 & 5.92 & 5.92 & $\begin{array}{l}\text { Plug-load calculation in } \\
\text { TSD sections 3.5.4 and } 4.3\end{array}$ \\
\hline Schedule & See Table A.2 & See Table A.3 & See Table A.3 & \\
\hline \multicolumn{5}{|l|}{ Elevator } \\
\hline Power (W) & 32,780 & 32,780 & 32,780 & \\
\hline Schedule & See Table A.2 & Same as baseline & Same as baseline & \\
\hline
\end{tabular}


Table A.1.b. SI Units (continued)

\begin{tabular}{|c|c|c|c|c|}
\hline Characteristic & Baseline & Advanced-Radiant & Advanced-VAV & Data Source/Remarks \\
\hline \multicolumn{5}{|c|}{ HVAC SYSTEM } \\
\hline \multicolumn{5}{|l|}{ System type } \\
\hline Heating/Cooling & $\begin{array}{l}\text { Packaged VAV system } \\
\text { - DX packaged air conditioning } \\
\text { unit for cooling } \\
\text { - gas furnace for heating }\end{array}$ & $\begin{array}{l}\text { Radiant floor heating and } \\
\text { cooling + DOAS } \\
\text { - air-cooled chiller for radiant } \\
\text { cooling } \\
\text { - condensing boiler for radiant } \\
\text { heating } \\
\text { - DOAS unit with DX coil for } \\
\text { cooling /dehumidification } \\
\text { and hot-water coil for } \\
\text { reheating }\end{array}$ & $\begin{array}{l}\text { Packaged VAV system } \\
\text { - DX packaged air } \\
\text { conditioning unit for } \\
\text { cooling } \\
\text { - gas furnace for heating } \\
\text { - indirect evaporative } \\
\text { cooler for precooling in } \\
\text { climate zones 2B, 3B, } \\
\text { 4B and 5B. }\end{array}$ & CBECS 2003 \\
\hline \multicolumn{5}{|l|}{ HVAC efficiency } \\
\hline Cooling efficiency & $\begin{array}{l}\text { DX cooling coil } \\
\text { - EER=9.0-10.1, depending on } \\
\text { the sized capacity } \\
\text { - performance curves see Table } \\
\text { A. } 4\end{array}$ & $\begin{array}{l}\text { Air cooled chiller } \\
\text { - COP=3.1 } \\
\text { - Chiller performance curves } \\
\text { see Table A.5 } \\
\text { DX coil in the DOAS unit } \\
\text { - EER }=11.3 \text { or } 11.5 \text {, } \\
\text { depending on the sized } \\
\text { capacity } \\
\text { - DOAS DX performance } \\
\text { curves see Table A.6 }\end{array}$ & $\begin{array}{l}\text { DX cooling coil } \\
\text { - EER=10.2-11.5, } \\
\text { depending on the sized } \\
\text { capacity } \\
\text { - performance curves see } \\
\text { Table A.4 } \\
\text { Indirect evaporative cooler } \\
\text { - effectiveness: } 0.7 \\
\text { - pressure drop: } 199 \mathrm{~Pa} \text {. }\end{array}$ & $\begin{array}{l}\text { ASHRAE 90.1-2004 } \\
\text { ASHRAE 90.1-2007 } \\
\text { Appliances database of } \\
\text { California Energy } \\
\text { Commission. } \\
\text { Manufactures' Catalog }\end{array}$ \\
\hline Heating efficiency & $\begin{array}{l}\text { Gas furnace } \\
\text { - } \text { burner efficiency }=0.78 \\
\quad \text { (capacity }<=65.9 \mathrm{~kW}) ;=0.80 \\
\text { (capacity }>65.9 \mathrm{~kW} \text { ) } \\
\text { - part load performance curve } \\
\text { see Table A.7 }\end{array}$ & $\begin{array}{l}\text { Condensing boiler } \\
\text { Thermal efficiency }=0.95\end{array}$ & Same as baseline & $\begin{array}{l}\text { ASHRAE 90.1-2004 } \\
\text { ASHRAE 90.1-2007 }\end{array}$ \\
\hline
\end{tabular}


Table A.1.b. SI Units (continued)

\begin{tabular}{|c|c|c|c|c|}
\hline Characteristic & Baseline & Advanced-Radiant & Advanced-VAV & Data Source/Remarks \\
\hline \multicolumn{5}{|l|}{ HVAC control } \\
\hline $\begin{array}{l}\text { Thermostat setpoint } \\
\left({ }^{\circ} \mathrm{C}\right)\end{array}$ & 23.9 cooling/ 21.1 heating & 23.9 cooling/19.4 heating & 23.9 cooling/ 21.1 heating & $\begin{array}{l}\text { Design practice } \\
\text { Jan et al. } 2009\end{array}$ \\
\hline $\begin{array}{l}\text { Thermostat setup / } \\
\text { setback }\left({ }^{\circ} \mathrm{C}\right)\end{array}$ & 26.7 cooling / 18.3 heating & 26.7 cooling / 18.3 heating & 26.7 cooling / 18.3 heating & Design practice \\
\hline $\begin{array}{l}\text { Plant loop } \\
\text { temperature control }\end{array}$ & NA & - $15^{\circ} \mathrm{C}$ for chilled water & NA & $\begin{array}{l}\text { Design practice } \\
\text { Jan et al. } 2009\end{array}$ \\
\hline Air system & $\begin{array}{l}\text { - Supply air temperature: } \\
12.8^{\circ} \mathrm{C} \\
\text { - No supply air temperature } \\
\text { reset }\end{array}$ & $\begin{array}{l}\text { - Supply air temperature: } \\
12.8^{\circ} \mathrm{C} \\
\text { - Supply air temperature reset } \\
\text { based on outside air } \\
\text { temperature (except climate } \\
\text { zones } 1-3 \text { ) }\end{array}$ & $\begin{array}{l}\text { - Supply air temperature: } \\
12.8^{\circ} \mathrm{C} \\
\text { - Supply air temperature } \\
\text { reset based on the } \\
\text { warmest thermal zone } \\
\text { (except climate zones } \\
1 \mathrm{~A}, 2 \mathrm{~A}, 3 \mathrm{~A} \text { and } 4 \mathrm{~A})\end{array}$ & \\
\hline $\begin{array}{l}\text { Hydronic radiant } \\
\text { system }\end{array}$ & NA & $\begin{array}{l}\text { - Variable flow based on mean } \\
\text { air temperature } \\
\text { - Temperature throttling } \\
\text { range: } 2^{\circ} \mathrm{C} \\
\text { - Radiant heating and cooling } \\
\text { setpoints see Figure } 4.6\end{array}$ & NA & \\
\hline \multicolumn{5}{|l|}{ Ventilation } \\
\hline Damper control & $\begin{array}{l}\text { Gravity damper is used for } \\
\text { climate zones 1-3; motorized } \\
\text { damper for other zones }\end{array}$ & $\begin{array}{l}\text { Motorized damper is used for } \\
\text { all climate zones }\end{array}$ & $\begin{array}{l}\text { Motorized damper is used } \\
\text { for all climate zones }\end{array}$ & ASHRAE 90.1-2004 \\
\hline $\begin{array}{l}\text { Demand controlled } \\
\text { ventilation }\end{array}$ & No & Yes & Yes & \\
\hline
\end{tabular}


Table A.1.b. SI Units (continued)

\begin{tabular}{|c|c|c|c|c|}
\hline Characteristic & Baseline & Advanced-Radiant & Advanced-VAV & Data Source/Remarks \\
\hline Energy recovery & No & $\begin{array}{l}\text { - Rotary heat exchanger is } \\
\text { used for energy recovery in } \\
\text { all climate zones except 3B- } \\
\text { CA and 3C. } \\
\text { - Heat recovery effectiveness } \\
\text { see Table } 4.10 \\
\text { - Frost control based on } \\
\text { minimum exhaust temperature } \\
\text { at } 1.7^{\circ} \mathrm{C}\end{array}$ & $\begin{array}{l}\text { - Rotary heat exchanger is } \\
\text { used for energy recovery } \\
\text { in all climate zones } \\
\text { except 3B and 3C. } \\
\text { - Heat recovery } \\
\text { effectiveness see } \\
\text { Table4.10 } \\
\text { - Frost control based on } \\
\text { minimum exhaust } \\
\text { temperature at } 1.7^{\circ} \mathrm{C}\end{array}$ & \\
\hline Economizer & $\begin{array}{l}\text { No economizer is used in } \\
\text { climate zones } 1 \mathrm{~A}, 2 \mathrm{~A}, 3 \mathrm{~A} \text { and } \\
4 \mathrm{~A} \text {; differential drybulb based } \\
\text { economizer is used for all other } \\
\text { zones. }\end{array}$ & No economizer for DOAS & $\begin{array}{l}\text { Differential enthalpy based } \\
\text { economizer is used in } \\
\text { climate zones } 1 \mathrm{~A}, 2 \mathrm{~A}, 3 \mathrm{~A} \\
\text { and } 4 \mathrm{~A} \text {; differential } \\
\text { drybulb based economizer } \\
\text { is used for all other zones. }\end{array}$ & ASHRAE 90.1-2004 \\
\hline $\begin{array}{l}\text { Fan System } \\
\text { Supply fan }\end{array}$ & $\begin{array}{l}\text { - Variable speed fan } \\
\text { - Fan mechanical efficiency: } \\
65 \% \\
\text { - Fan motor efficiency based on } \\
\text { motor power (See Table 4.12) } \\
\text { - Part-load performance curve } \\
\text { see Table A.8 }\end{array}$ & $\begin{array}{l}\text { - Constant speed fan for the } \\
\text { DOAS } \\
\text { - Fan mechanical efficiency: } \\
65 \% \\
\text { - Fan motor efficiency based } \\
\text { on motor power (See Table } \\
4.12 \text { ) }\end{array}$ & $\begin{array}{l}\text { - Variable speed fan } \\
\text { - Fan mechanical } \\
\text { efficiency: } 65 \% \\
\text { - Fan motor efficiency } \\
\text { based on motor power } \\
\text { (See Table 4.12) } \\
\text { - Part-load performance } \\
\text { curve see Table A.6 }\end{array}$ & \\
\hline Exhaust/return fan & Not explicitly modeled. & Same as baseline & Same as baseline & \\
\hline $\begin{array}{l}\text { Fan system static } \\
\text { pressure }\end{array}$ & $1,574 \mathrm{~Pa}$ & $\begin{array}{l}\text { - } 623 \mathrm{~Pa} \\
\text { - Additional } 374 \text { Pa pressure } \\
\text { drop for ERV. }\end{array}$ & $\begin{array}{l}\text { - If supply air m3/s }< \\
\text { 2.19, the static pressure } \\
\text { is } 847 \mathrm{~Pa} \text {.; otherwise, } \\
\text { the pressure } 1241 \mathrm{~Pa} \text {. } \\
\text { - Additional } 374 \mathrm{~Pa} \\
\text { pressure drop for ERV. } \\
\text { - Additional } 199 \mathrm{~Pa} \\
\text { pressure if evaporative } \\
\text { cooling is used. }\end{array}$ & $\begin{array}{l}\text { Derived from fan power } \\
\text { limitation in ASHRAE 90.1- } \\
2004\end{array}$ \\
\hline
\end{tabular}


Table A.1.b. SI Units (continued)

\begin{tabular}{|c|c|c|c|c|}
\hline Characteristic & Baseline & Advanced-Radiant & Advanced-VAV & Data Source/Remarks \\
\hline \multicolumn{5}{|c|}{ SERVICE WATER HEATING } \\
\hline $\begin{array}{l}\text { Gas-fired water } \\
\text { heater }\end{array}$ & $\begin{array}{l}\text { - Conventional type with } \\
\text { thermal efficiency }=80 \% \\
\text { - } \text { Tank volume }=0.757 \mathrm{~m}^{3} \\
\text { - Standby heat loss coefficient } \\
=8.118 \mathrm{~W} / \mathrm{K}\end{array}$ & $\begin{array}{l}\text { - Condensing water heater } \\
\text { with thermal efficiency }= \\
95 \% \text {. } \\
\text { - Tank volume }=0.757 \mathrm{~m}^{3} \\
\text { gallon } \\
\text { - Standby heat loss coefficient } \\
=8.118 \mathrm{~W} / \mathrm{K}\end{array}$ & Same as for Radiant & $\begin{array}{l}\text { ASHRAE 90.1-2004 } \\
\text { Manufacturers' Catalog }\end{array}$ \\
\hline
\end{tabular}


Table A.3. Major Schedules for the Baseline Model

\begin{tabular}{|c|c|c|c|c|c|c|c|c|c|c|c|c|c|c|c|c|c|c|c|c|c|c|c|c|c|}
\hline Schedule & Day Type & 1 & 2 & 3 & 4 & 5 & 6 & 7 & 8 & 9 & 10 & 11 & 12 & 13 & 14 & 15 & 16 & 17 & 18 & 19 & 20 & 21 & 22 & 23 & 24 \\
\hline \multicolumn{26}{|c|}{ Internal Loads Schedules } \\
\hline \multirow{3}{*}{$\begin{array}{l}\text { Lighting } \\
\text { (Fraction) }\end{array}$} & WD & 0.15 & 0.15 & 0.15 & 0.15 & 0.15 & 0.15 & 0.15 & 0.3 & 0.9 & 0.9 & 0.9 & 0.9 & 0.8 & 0.9 & 0.9 & 0.9 & 0.9 & 0.5 & 0.3 & 0.3 & 0.2 & 0.2 & 0.15 & 0.15 \\
\hline & Sat & 0.15 & 0.15 & 0.15 & 0.15 & 0.15 & 0.15 & 0.15 & 0.15 & 0.3 & 0.3 & 0.3 & 0.3 & 0.15 & 0.15 & 0.15 & 0.15 & 0.15 & 0.15 & 0.15 & 0.15 & 0.15 & 0.15 & 0.15 & 0.15 \\
\hline & Sun, Hol & 0.15 & 0.15 & 0.15 & 0.15 & 0.15 & 0.15 & 0.15 & 0.15 & 0.15 & 0.15 & 0.15 & 0.15 & 0.15 & 0.15 & 0.15 & 0.15 & 0.15 & 0.15 & 0.15 & 0.15 & 0.15 & 0.15 & 0.15 & 0.15 \\
\hline \multirow{3}{*}{$\begin{array}{l}\text { Plug load } \\
\text { (Fraction) }\end{array}$} & WD & 0.4 & 0.4 & 0.4 & 0.4 & 0.4 & 0.4 & 0.4 & 0.4 & 0.9 & 0.9 & 0.9 & 0.9 & 0.8 & 0.9 & 0.9 & 0.9 & 0.9 & 0.5 & 0.4 & 0.4 & 0.4 & 0.4 & 0.4 & 0.4 \\
\hline & Sat & 0.3 & 0.3 & 0.3 & 0.3 & 0.3 & 0.3 & 0.4 & 0.4 & 0.5 & 0.5 & 0.5 & 0.5 & 0.35 & 0.35 & 0.35 & 0.35 & 0.35 & 0.3 & 0.3 & 0.3 & 0.3 & 0.3 & 0.3 & 0.3 \\
\hline & Sun, Hol & 0.3 & 0.3 & 0.3 & 0.3 & 0.3 & 0.3 & 0.3 & 0.3 & 0.3 & 0.3 & 0.3 & 0.3 & 0.3 & 0.3 & 0.3 & 0.3 & 0.3 & 0.3 & 0.3 & 0.3 & 0.3 & 0.3 & 0.3 & 0.3 \\
\hline \multirow{3}{*}{$\begin{array}{l}\text { Occupancy } \\
\text { (Fraction) }\end{array}$} & WD & 0 & 0 & 0 & 0 & 0 & 0 & 0.1 & 0.2 & 0.95 & 0.95 & 0.95 & 0.95 & 0.5 & 0.95 & 0.95 & 0.95 & 0.95 & 0.3 & 0.1 & 0.1 & 0.1 & 0.1 & 0.05 & 0.05 \\
\hline & Sat & 0 & 0 & 0 & 0 & 0 & 0 & 0.1 & 0.1 & 0.3 & 0.3 & 0.3 & 0.3 & 0.1 & 0.1 & 0.1 & 0.1 & 0.1 & 0.05 & 0.05 & 0 & 0 & 0 & 0 & 0 \\
\hline & Sun, Hol & 0 & 0 & 0 & 0 & 0 & 0 & 0.05 & 0.05 & 0.05 & 0.05 & 0.05 & 0.05 & 0.05 & 0.05 & 0.05 & 0.05 & 0.05 & 0.05 & 0 & 0 & 0 & 0 & 0 & 0 \\
\hline \multirow{3}{*}{$\begin{array}{l}\text { Elevator } \\
\text { (Fraction) }\end{array}$} & WD & 0 & 0 & 0 & 0 & 0 & 0 & 0 & 0.35 & 0.69 & 0.43 & 0.37 & 0.43 & 0.58 & 0.48 & 0.37 & 0.37 & 0.46 & 0.62 & 0.12 & 0.04 & 0.04 & 0 & 0 & 0 \\
\hline & Sat & 0 & 0 & 0 & 0 & 0 & 0 & 0 & 0.16 & 0.14 & 0.21 & 0.18 & 0.25 & 0.21 & 0.13 & 0.08 & 0.04 & 0.05 & 0.06 & 0 & 0 & 0 & 0 & 0 & 0 \\
\hline & Sun, Hol & 0 & 0 & 0 & 0 & 0 & 0 & 0 & 0 & 0 & 0 & 0 & 0 & 0 & 0 & 0 & 0 & 0 & 0 & 0 & 0 & 0 & 0 & 0 & 0 \\
\hline \multicolumn{26}{|c|}{ Service Hot Water Schedule } \\
\hline \multirow{3}{*}{$\begin{array}{l}\text { Hot water } \\
\text { (Fraction) }\end{array}$} & WD & 0.05 & 0.05 & 0.05 & 0.05 & 0.05 & 0.08 & 0.07 & 0.19 & 0.35 & 0.38 & 0.39 & 0.47 & 0.57 & 0.54 & 0.34 & 0.33 & 0.44 & 0.26 & 0.21 & 0.15 & 0.17 & 0.08 & 0.05 & 0.05 \\
\hline & Sat & 0.05 & 0.05 & 0.05 & 0.05 & 0.05 & 0.08 & 0.07 & 0.11 & 0.15 & 0.21 & 0.19 & 0.23 & 0.2 & 0.19 & 0.15 & 0.13 & 0.14 & 0.07 & 0.07 & 0.07 & 0.07 & 0.09 & 0.05 & 0.05 \\
\hline & Sun, Hol & 0.04 & 0.04 & 0.04 & 0.04 & 0.04 & 0.07 & 0.04 & 0.04 & 0.04 & 0.04 & 0.04 & 0.06 & 0.06 & 0.09 & 0.06 & 0.04 & 0.04 & 0.04 & 0.04 & 0.04 & 0.04 & 0.07 & 0.04 & 0.04 \\
\hline \multicolumn{26}{|c|}{ HVAC Schedules } \\
\hline \multirow{3}{*}{$\begin{array}{l}\text { HVAC system } \\
\text { (on/off) }\end{array}$} & WD & 0 & 0 & 0 & 0 & 0 & 0 & 1 & 1 & 1 & 1 & 1 & 1 & 1 & 1 & 1 & 1 & 1 & 1 & 1 & 1 & 1 & 1 & 0 & 0 \\
\hline & Sat & 0 & 0 & 0 & 0 & 0 & 0 & 1 & 1 & 1 & 1 & 1 & 1 & 1 & 1 & 1 & 1 & 1 & 1 & 0 & 0 & 0 & 0 & 0 & 0 \\
\hline & Sun, Hol & 0 & 0 & 0 & 0 & 0 & 0 & 0 & 0 & 0 & 0 & 0 & 0 & 0 & 0 & 0 & 0 & 0 & 0 & 0 & 0 & 0 & 0 & 0 & 0 \\
\hline \multirow{3}{*}{$\begin{array}{l}\text { Heating } \\
\text { setpoint } \\
\left({ }^{\circ} \mathrm{F}\right)\end{array}$} & WD & 65 & 65 & 65 & 65 & 65 & 65 & 67 & 70 & 70 & 70 & 70 & 70 & 70 & 70 & 70 & 70 & 70 & 70 & 70 & 70 & 70 & 70 & 65 & 65 \\
\hline & Sat & 65 & 65 & 65 & 65 & 65 & 65 & 67 & 70 & 70 & 70 & 70 & 70 & 70 & 70 & 70 & 70 & 70 & 65 & 65 & 65 & 65 & 65 & 65 & 65 \\
\hline & Sun, Hol & 65 & 65 & 65 & 65 & 65 & 65 & 65 & 65 & 65 & 65 & 65 & 65 & 65 & 65 & 65 & 65 & 65 & 65 & 65 & 65 & 65 & 65 & 65 & 65 \\
\hline \multirow{3}{*}{$\begin{array}{l}\text { Cooling } \\
\text { setpoint } \\
\left({ }^{\circ} \mathrm{F}\right)\end{array}$} & WD & 80 & 80 & 80 & 80 & 80 & 78 & 77 & 75 & 75 & 75 & 75 & 75 & 75 & 75 & 75 & 75 & 75 & 75 & 75 & 75 & 75 & 75 & 80 & 80 \\
\hline & Sat & 80 & 80 & 80 & 80 & 80 & 78 & 77 & 75 & 75 & 75 & 75 & 75 & 75 & 75 & 75 & 75 & 75 & 80 & 80 & 80 & 80 & 80 & 80 & 80 \\
\hline & Sun, Hol & 80 & 80 & 80 & 80 & 80 & 80 & 80 & 80 & 80 & 80 & 80 & 80 & 80 & 80 & 80 & 80 & 80 & 80 & 80 & 80 & 80 & 80 & 80 & 80 \\
\hline
\end{tabular}


Table A.4. Major Schedules for the Advanced Model

\begin{tabular}{|c|c|c|c|c|c|c|c|c|c|c|c|c|c|c|c|c|c|c|c|c|c|c|c|c|c|}
\hline Schedule & $\begin{array}{l}\text { Day } \\
\text { Type }\end{array}$ & 1 & 2 & 3 & 4 & 5 & 6 & 7 & 8 & 9 & 10 & 11 & 12 & 13 & 14 & 15 & 16 & 17 & 18 & 19 & 20 & 21 & 22 & 23 & 24 \\
\hline \multicolumn{26}{|c|}{ Internal Loads Schedules } \\
\hline \multirow{3}{*}{$\begin{array}{l}\text { Lighting } \\
\text { (Fraction) }\end{array}$} & WD & 0.1 & 0.1 & 0.1 & 0.1 & 0.1 & 0.1 & 0.1 & 0.3 & 0.77 & 0.77 & 0.77 & 0.77 & 0.77 & 0.77 & 0.77 & 0.77 & 0.77 & 0.5 & 0.3 & 0.3 & 0.2 & 0.2 & 0.1 & 0.1 \\
\hline & Sat & 0.1 & 0.1 & 0.1 & 0.1 & 0.1 & 0.1 & 0.1 & 0.1 & 0.3 & 0.3 & 0.3 & 0.3 & 0.1 & 0.1 & 0.1 & 0.1 & 0.1 & 0.1 & 0.1 & 0.1 & 0.1 & 0.1 & 0.1 & 0.1 \\
\hline & Sun, Hol & 0.1 & 0.1 & 0.1 & 0.1 & 0.1 & 0.1 & 0.1 & 0.1 & 0.1 & 0.1 & 0.1 & 0.1 & 0.1 & 0.1 & 0.1 & 0.1 & 0.1 & 0.1 & 0.1 & 0.1 & 0.1 & 0.1 & 0.1 & 0.1 \\
\hline \multirow{3}{*}{$\begin{array}{l}\text { Plug load } \\
\text { (Fraction) }\end{array}$} & WD & 0.3 & 0.3 & 0.3 & 0.3 & 0.3 & 0.3 & 0.3 & 0.3 & 0.85 & 0.85 & 0.85 & 0.85 & 0.75 & 0.85 & 0.85 & 0.85 & 0.85 & 0.45 & 0.3 & 0.3 & 0.3 & 0.3 & 0.3 & 0.3 \\
\hline & Sat & 0.2 & 0.2 & 0.2 & 0.2 & 0.2 & 0.2 & 0.3 & 0.3 & 0.35 & 0.35 & 0.35 & 0.35 & 0.25 & 0.25 & 0.25 & 0.25 & 0.25 & 0.2 & 0.2 & 0.2 & 0.2 & 0.2 & 0.2 & 0.2 \\
\hline & Sun, Hol & 0.2 & 0.2 & 0.2 & 0.2 & 0.2 & 0.2 & 0.2 & 0.2 & 0.2 & 0.2 & 0.2 & 0.2 & 0.2 & 0.2 & 0.2 & 0.2 & 0.2 & 0.2 & 0.2 & 0.2 & 0.2 & 0.2 & 0.2 & 0.2 \\
\hline \multirow{3}{*}{$\begin{array}{l}\text { Occupancy } \\
\text { (Fraction) }\end{array}$} & WD & 0 & 0 & 0 & 0 & 0 & 0 & 0.1 & 0.2 & 0.95 & 0.95 & 0.95 & 0.95 & 0.5 & 0.95 & 0.95 & 0.95 & 0.95 & 0.3 & 0.1 & 0.1 & 0.1 & 0.1 & 0.05 & 0.05 \\
\hline & Sat & 0 & 0 & 0 & 0 & 0 & 0 & 0.1 & 0.1 & 0.3 & 0.3 & 0.3 & 0.3 & 0.1 & 0.1 & 0.1 & 0.1 & 0.1 & 0.05 & 0.05 & 0 & 0 & 0 & 0 & 0 \\
\hline & Sun, Hol & 0 & 0 & 0 & 0 & 0 & 0 & 0.05 & 0.05 & 0.05 & 0.05 & 0.05 & 0.05 & 0.05 & 0.05 & 0.05 & 0.05 & 0.05 & 0.05 & 0 & 0 & 0 & 0 & 0 & 0 \\
\hline \multirow{3}{*}{$\begin{array}{l}\text { Elevator } \\
\text { (Fraction) }\end{array}$} & WD & 0 & 0 & 0 & 0 & 0 & 0 & 0 & 0.35 & 0.69 & 0.43 & 0.37 & 0.43 & 0.58 & 0.48 & 0.37 & 0.37 & 0.46 & 0.62 & 0.12 & 0.04 & 0.04 & 0 & 0 & 0 \\
\hline & Sat & 0 & 0 & 0 & 0 & 0 & 0 & 0 & 0.16 & 0.14 & 0.21 & 0.18 & 0.25 & 0.21 & 0.13 & 0.08 & 0.04 & 0.05 & 0.06 & 0 & 0 & 0 & 0 & 0 & 0 \\
\hline & Sun, Hol & 0 & 0 & 0 & 0 & 0 & 0 & 0 & 0 & 0 & 0 & 0 & 0 & 0 & 0 & 0 & 0 & 0 & 0 & 0 & 0 & 0 & 0 & 0 & 0 \\
\hline \multicolumn{26}{|c|}{ Service Hot Water Schedule } \\
\hline \multirow{3}{*}{$\begin{array}{l}\text { Hot water } \\
\text { (Fraction) }\end{array}$} & WD & 0.05 & 0.05 & 0.05 & 0.05 & 0.05 & 0.08 & 0.07 & 0.19 & 0.35 & 0.38 & 0.39 & 0.47 & 0.57 & 0.54 & 0.34 & 0.33 & 0.44 & 0.26 & 0.21 & 0.1 & 0.17 & 0.08 & 0.05 & 0.05 \\
\hline & Sat & 0.05 & 0.05 & 0.05 & 0.05 & 0.05 & 0.08 & 0.07 & 0.11 & 0.1 & 0.21 & 0.19 & 0.23 & 0.2 & 0.19 & 0.1 & 0.13 & 0.14 & 0.07 & 0.07 & 0.07 & 0.07 & 0.09 & 0.05 & 0.05 \\
\hline & Sun, Hol & 0.04 & 0.04 & 0.04 & 0.04 & 0.04 & 0.07 & 0.04 & 0.04 & 0.04 & 0.04 & 0.04 & 0.06 & 0.06 & 0.09 & 0.06 & 0.04 & 0.04 & 0.04 & 0.04 & 0.04 & 0.04 & 0.07 & 0.04 & 0.04 \\
\hline \multicolumn{26}{|c|}{ HVAC Schedules } \\
\hline \multirow{3}{*}{$\begin{array}{l}\text { HVAC } \\
\text { system } \\
\text { (on/off) }\end{array}$} & WD & 0 & 0 & 0 & 0 & 0 & 0 & 1 & 1 & 1 & 1 & 1 & 1 & 1 & 1 & 1 & 1 & 1 & 1 & 1 & 1 & 1 & 1 & 0 & 0 \\
\hline & Sat & 0 & 0 & 0 & 0 & 0 & 0 & 1 & 1 & 1 & 1 & 1 & 1 & 1 & 1 & 1 & 1 & 1 & 1 & 0 & 0 & 0 & 0 & 0 & 0 \\
\hline & Sun, Hol & 0 & 0 & 0 & 0 & 0 & 0 & 0 & 0 & 0 & 0 & 0 & 0 & 0 & 0 & 0 & 0 & 0 & 0 & 0 & 0 & 0 & 0 & 0 & 0 \\
\hline \multirow{3}{*}{$\begin{array}{l}\text { Heating } \\
\text { setpoint } \\
\left({ }^{\circ} \mathrm{F}\right)\end{array}$} & WD & 65 & 65 & 65 & 65 & 65 & 65 & 67 & 67 & 67 & 67 & 67 & 67 & 67 & 67 & 67 & 67 & 67 & 67 & 67 & 67 & 67 & 67 & 65 & 65 \\
\hline & Sat & 65 & 65 & 65 & 65 & 65 & 65 & 67 & 67 & 67 & 67 & 67 & 67 & 67 & 67 & 67 & 67 & 67 & 65 & 65 & 65 & 65 & 65 & 65 & 65 \\
\hline & Sun, Hol & 65 & 65 & 65 & 65 & 65 & 65 & 65 & 65 & 65 & 65 & 65 & 65 & 65 & 65 & 65 & 65 & 65 & 65 & 65 & 65 & 65 & 65 & 65 & 65 \\
\hline \multirow{3}{*}{$\begin{array}{l}\text { Cooling } \\
\text { setpoint } \\
\left({ }^{\circ} \mathrm{F}\right)\end{array}$} & WD & 80 & 80 & 80 & 80 & 80 & 78 & 77 & 75 & 75 & 75 & 75 & 75 & 75 & 75 & 75 & 75 & 75 & 75 & 75 & 75 & 75 & 75 & 80 & 80 \\
\hline & Sat & 80 & 80 & 80 & 80 & 80 & 78 & 77 & 75 & 75 & 75 & 75 & 75 & 75 & 75 & 75 & 75 & 75 & 80 & 80 & 80 & 80 & 80 & 80 & 80 \\
\hline & Sun, Hol & 80 & 80 & 80 & 80 & 80 & 80 & 80 & 80 & 80 & 80 & 80 & 80 & 80 & 80 & 80 & 80 & 80 & 80 & 80 & 80 & 80 & 80 & 80 & 80 \\
\hline
\end{tabular}


Table A.5. Performance Curves for the DX Coils Used in the Packaged VAV System

\begin{tabular}{|c|c|c|c|c|c|c|}
\hline \multirow[b]{2}{*}{ curve name } & \multicolumn{6}{|c|}{ coefficients } \\
\hline & $\mathrm{a}$ & $\mathrm{b}$ & c & $\mathrm{d}$ & e & $\mathrm{f}$ \\
\hline \multicolumn{7}{|l|}{ Total cooling capacity modifier function of temperature } \\
\hline $\operatorname{Cap}\left(T_{w b, i}, T_{c, i}\right)=a+b\left(T_{w b, i}\right)+c\left(T_{w b, i}\right)^{2}+d\left(T_{c, i}\right)+e\left(T_{c, i}\right)^{2}+f\left(T_{w b, i}\right)\left(T_{c, i}\right)$ & 1.39072 & -0.05291 & 0.001842 & 0.000583 & -0.00019 & 0.000265 \\
\hline \multicolumn{7}{|l|}{ Total cooling capacity modifier function of flow fraction } \\
\hline $\operatorname{Cap}(f f)=a+b(f f)+c(f f)^{2}$ & 0.718954 & 0.435436 & -0.1419 & - & - & - \\
\hline $\operatorname{EIR}\left(T_{w b, i}, T_{c, i}\right)=a+b\left(T_{w b, i}\right)+c\left(T_{w b, i}\right)^{2}+d\left(T_{c, i}\right)+e\left(T_{c, i}\right)^{2}+f\left(T_{w b, i}\right)\left(T_{c, i}\right)$ & -0.53616 & 0.105138 & -0.00173 & 0.014985 & 0.00066 & -0.00174 \\
\hline \multicolumn{7}{|l|}{ EIR modifier function of flow fraction } \\
\hline$E I R(f f)=a+b(f f)+c(f f)^{2}$ & 1.19525 & -0.30614 & 0.110973 & - & - & - \\
\hline \multicolumn{7}{|c|}{$T_{c, i}-$ dry-bulb temperature of the air entering the air-cooled condenser $\left({ }^{\circ} \mathrm{C}\right)$} \\
\hline \multicolumn{7}{|c|}{ ff - the ratio of the actual air flow rate across the cooling coil to the rated air flow rate } \\
\hline
\end{tabular}


Table A.6. Performance Curves for the Air-Cooled Chiller

\begin{tabular}{|c|c|c|c|c|c|c|}
\hline \multirow[b]{2}{*}{ curve name } & \multicolumn{6}{|c|}{ coefficients } \\
\hline & a & $\mathrm{b}$ & c & $\mathrm{d}$ & e & $\mathrm{f}$ \\
\hline \multicolumn{7}{|l|}{ Total cooling capacity modifier function of temperature } \\
\hline $\operatorname{Cap}\left(T_{c w, l}, T_{c o n, e}\right)=a+b\left(T_{c w, l}\right)+c\left(T_{c w, l}\right)^{2}+d\left(T_{c o n, e}\right)+e\left(T_{c o n, e}\right)^{2}+f\left(T_{c w, l}\right)\left(T_{c o n, e}\right)$ & 1.0215 & 0.037 & 0.0002 & -0.0039 & -0.0001 & -0.0003 \\
\hline \multicolumn{7}{|l|}{ EIR modifier function of temperature } \\
\hline$E I R\left(T_{c w, l}, T_{c o n, e}\right)=a+b\left(T_{c w, l}\right)+c\left(T_{c w, l}\right)^{2}+d\left(T_{c o n, e}\right)+e\left(T_{c o n, e}\right)^{2}+f\left(T_{c w, l}\right)\left(T_{c o n, e}\right)$ & 0.8748 & -0.0045 & 0.0005 & -0.0055 & 0.0005 & -0.0007 \\
\hline \multicolumn{7}{|l|}{ Part load correction function } \\
\hline$P L F(P L R)=a+b(P L R)+c(P L R)^{2}$ & 0.0637 & 0.5849 & 0.3528 & - & - & - \\
\hline \multicolumn{7}{|l|}{$T_{c w, l}$ - leaving chilled water temperature $\left({ }^{\circ} \mathrm{C}\right)$} \\
\hline \multicolumn{7}{|l|}{$T_{c o n, e}-$ entering condenser water temperature $\left({ }^{\circ} \mathrm{C}\right)$} \\
\hline PLR - part load ratio (the ratio between actual chiller load and its available capacity) & & & & & & \\
\hline
\end{tabular}


Table A.7. Performance Curves for the DX Coil Used in the DOAS System

\begin{tabular}{|c|c|c|c|c|c|c|}
\hline \multirow[b]{2}{*}{ curve name } & \multicolumn{6}{|c|}{ coefficients } \\
\hline & $\mathrm{a}$ & $\mathrm{b}$ & c & $\mathrm{d}$ & $\mathrm{e}$ & $\mathrm{f}$ \\
\hline \multicolumn{7}{|l|}{ Total cooling capacity modifier function of temperature } \\
\hline $\operatorname{Cap}\left(T_{w b, i}, T_{c, i}\right)=a+b\left(T_{w b, i}\right)+c\left(T_{w b, i}\right)^{2}+d\left(T_{c, i}\right)+e\left(T_{c, i}\right)^{2}+f\left(T_{w b, i}\right)\left(T_{c, i}\right)$ & 0.942588 & 0.009543 & 0.000684 & -0.01104 & 5.25E-06 & $-9.7 \mathrm{E}-06$ \\
\hline \multicolumn{7}{|l|}{ Total cooling capacity modifier function of flow fraction } \\
\hline $\operatorname{Cap}(f f)=a+b(f f)+c(f f)^{2}$ & 0.8 & 0.2 & 0 & - & - & - \\
\hline \multicolumn{7}{|l|}{ EIR modifier function of temperature } \\
\hline $\operatorname{EIR}\left(T_{w b, i}, T_{c, i}\right)=a+b\left(T_{w b, i}\right)+c\left(T_{w b, i}\right)^{2}+d\left(T_{c, i}\right)+e\left(T_{c, i}\right)^{2}+f\left(T_{w b, i}\right)\left(T_{c, i}\right)$ & 0.342414 & 0.034885 & -0.00062 & 0.004977 & 0.000438 & -0.00073 \\
\hline \multicolumn{7}{|l|}{ EIR modifier function of flow fraction } \\
\hline$E I R(f f)=a+b(f f)+c(f f)^{2}$ & 1.1552 & -0.1808 & 0.0256 & - & - & - \\
\hline \multicolumn{7}{|l|}{ Part load correction function } \\
\hline$P L F(P L R)=a+b(P L R)+c(P L R)^{2}$ & 0.85 & 0.1 & 0 & - & - & - \\
\hline
\end{tabular}


Table A.8. Part Load Performance Curve for the Gas Furnace

\begin{tabular}{l}
\hline \\
\cline { 2 - 3 } curve name
\end{tabular}

Table A.9. Part Load Performance Curve for the Variable Speed Fan

\begin{tabular}{|c|c|c|c|c|c|}
\hline \multirow[b]{2}{*}{ curve name } & \multicolumn{5}{|c|}{ coefficients } \\
\hline & $\mathrm{a}$ & $\mathrm{b}$ & $\mathrm{c}$ & $\mathrm{d}$ & e \\
\hline \multicolumn{6}{|l|}{ Part load correction function } \\
\hline$P L F(P L R)=a+b(P L R)+c(P L R)^{2}$ & 0.0013 & 0.147 & 0.9506 & -0.0998 & 0 \\
\hline
\end{tabular}


Appendix B

Review Comments and Responses 
Table B.1 TSD Draft Report Review Comments and Responses

\begin{tabular}{|c|c|c|c|c|}
\hline No. & Category & Comment & PNNL Response & PNNL Action \\
\hline 1 & $\begin{array}{l}\text { Bldg } \\
\text { Form }\end{array}$ & $\begin{array}{l}\text { What is the floor to floor and floor to ceiling heights? Is there a } \\
\text { dropped ceiling which represents an additional insulation layer. }\end{array}$ & $\begin{array}{l}13 \text { feet floor to floor, and } 9 \text { feet } \\
\text { floor to ceiling. Plenum is } \\
\text { return air, so moving } \\
\text { conditioned air. Drop ceiling } \\
\text { also subject to infiltration with } \\
\text { conditioned space. Will not add } \\
\text { significant insulation value. }\end{array}$ & No action \\
\hline 2 & $\begin{array}{l}\text { Bldg } \\
\text { Form }\end{array}$ & $\begin{array}{l}\text { Is this a sacred cow? Why not suggest less window area. You're } \\
\text { starting at a fairly high value ( } 33 \% \text { ). What would a building look like } \\
\text { with } 25 \% \text { window area and what are the integrated design benefits } \\
\text { (reduced equipment size, reduced capital costs that could be rolled into } \\
\text { other EEMs). At least getting the window area on the east and west } \\
\text { orientations minimized would be a good start. As your numbers } \\
\text { indicate, we aren't going to get to } 50 \% \text { energy reduction unless with } \\
\text { get smarter with architectural design and the use of windows. If a } \\
\text { more sustainable building or net-zero energy building means having a } \\
\text { discussion about window area, lets start talking. The TSD or Advance } \\
\text { Design Guideline products should lead the way and at least show an } \\
\text { optional track that highlights the benefit of optimizing window area } \\
\text { and window placement. The importance of this issue is climate } \\
\text { dependent. }\end{array}$ & $\begin{array}{l}\text { This is a difficult battle to fight } \\
\text { and win with the design and } \\
\text { developer community. We ran } \\
\text { a model with } 15 \% \text { window to } \\
\text { wall area on the west and saw } \\
\text { about a } 1 \% \text { drop in energy } \\
\text { usage. All sides could not be } \\
\text { reduced to } 15 \% \text {, so if impact is } \\
\text { closer to } 0.5 \% \text { average per side, } \\
\text { including daylighting offset, } \\
\text { impact for perhaps } 25 \% \text { overall } \\
\text { might be closer to } 2 \% \text { total } \\
\text { savings. }\end{array}$ & $\begin{array}{l}\text { No further action to incorporate } \\
\text { in the model was taken as } \\
\text { achieving well over } 50 \% \text { for } \\
\text { advanced case with radiant } \\
\text { systems. Mention was added in } \\
\text { the TSD of the value of reducing } \\
\text { window to wall ratio particularly } \\
\text { on the east and west. This } \\
\text { strategy is worth pursuing in } \\
\text { future work such as for the small } \\
\text { office. Important to defined } \\
\text { prototype model to allow such } \\
\text { strategies to be applied more } \\
\text { readily--separate windows that } \\
\text { can be scaled in width as well as } \\
\text { height instead of ribbon windows. } \\
\text { However code change may be } \\
\text { needed to adopt this more widely } \\
\text { because of strong resistance from } \\
\text { architects and developer with } \\
\text { belief in large window areas } \\
\text { selling buildings and attracting } \\
\text { occupants. }\end{array}$ \\
\hline 3 & $\begin{array}{l}\text { Bldg } \\
\text { Form }\end{array}$ & $\begin{array}{l}\text { Interesting that open office area is programmed to be smaller than } \\
\text { private office area. }\end{array}$ & Yes, see footnote on source. & No action \\
\hline
\end{tabular}




\begin{tabular}{|c|c|c|c|c|}
\hline No. & Category & Comment & PNNL Response & PNNL Action \\
\hline 4 & $\begin{array}{l}\text { Bldg } \\
\text { Form }\end{array}$ & $\begin{array}{l}\text { I would like to suggest another analysis regarding the shape of the } \\
\text { building. Since the internal loads determine the energy consumption } \\
\text { of a commercial building, it might be interesting to analyze a building } \\
\text { with less depth and, thus, smaller core areas. For example, the } \\
\text { building could still be } 50 \text { m long, but only } 16.5 \text { m wide (aspect ratio } \\
\text { 3!). To compensate for the gross floor area, it could have } 6 \text { instead of } \\
3 \text { stories. I have no idea what this would mean for the overall energy } \\
\text { efficiency, but it would definitely improve day lighting (what means } \\
\text { less artificial light) and natural ventilation. Would it be possible to } \\
\text { analyze the energy use intensities for the perimeter and core zones } \\
\text { individually to get a first idea whether this would bring us in the right } \\
\text { direction? }\end{array}$ & $\begin{array}{l}\text { While this is an interesting } \\
\text { concept, building aspect } \\
\text { ratio is largely driven by } \\
\text { site constraints. Such a } \\
\text { change would be difficult to } \\
\text { implement in reality } \\
\text { consistently across projects. } \\
\text { This would increase the } \\
\text { ratio of building envelope } \\
\text { to usable floor area, which } \\
\text { would tend to offset } \\
\text { savings, and by adding } \\
\text { more floors, would increase } \\
\text { other costs as well. }\end{array}$ & No action \\
\hline 5 & Envelope & $\begin{array}{l}\text { Interesting to see stucco selected. Living in suburbia Portland I have } \\
\text { seen a lot of new commercial properties go up and they are almost all } \\
\text { tilt up concrete with and without brick veneer. }\end{array}$ & $\begin{array}{l}\text { Stucco has similar thermal } \\
\text { properties as many other } \\
\text { finishes. Choice of steel } \\
\text { framed walls was based on } \\
2003 \text { CBECS data. Most } \\
\text { buildings of this type are } \\
\text { steel-framed. Concrete or } \\
\text { concrete masonry unit } \\
\text { follow. We ran baseline } \\
\text { model with 6" concrete } \\
\text { walls with same insulation } \\
\text { R-value as with metal } \\
\text { framed wall, and less than a } \\
1 \% \text { savings resulted. }\end{array}$ & No action \\
\hline 6 & Envelope & $\begin{array}{l}\text { Above the rigid insulation there is typically some form of wood } \\
\text { sheathing that the roof membrane is attached to. }\end{array}$ & $\begin{array}{l}\text { This is not always the case, } \\
\text { particularly with tapered } \\
\text { formed rigid insulation that } \\
\text { also serves a run-off } \\
\text { function. This would add } \\
\text { only a modest amount to } \\
\text { roof R-value. }\end{array}$ & No action \\
\hline 7 & Envelope & $\begin{array}{l}\text { Typically fire proofing under metal deck adds insulation value. Does } \\
\text { the rigid insulation sit directly on top of the metal decking or is there a } \\
\text { wood or gypsum lay between the deck and insulation? }\end{array}$ & $\begin{array}{l}\text { Fire proofing and sheathing } \\
\text { together could add a modest } \\
\text { R-value on the margin. } \\
\text { Fire-proofing insulation } \\
\text { value is subject to } \\
\text { inconsistency in application }\end{array}$ & No action \\
\hline
\end{tabular}




\begin{tabular}{|c|c|c|c|c|}
\hline No. & Category & Comment & PNNL Response & PNNL Action \\
\hline & & & $\begin{array}{l}\text { and more complex heat } \\
\text { transfer through joists } \\
\text { and/or beams. Penetrations } \\
\text { and gaps in roof insulation } \\
\text { are not accounted for in the } \\
\text { existing R-value, so adding } \\
\text { more R-value may not be } \\
\text { accurate. Such a change } \\
\text { would result in a very small } \\
\text { reduction in both baseline } \\
\text { and advanced energy usage. } \\
\text { This was tested for } \\
\text { additional of R3 to roof } \\
\text { insulation value for } \\
\text { Baltimore, a good average } \\
\text { climate for range of } \\
\text { analysis. Baseline usage } \\
\text { reduced under } 1 \% \text {, } \\
\text { advanced by } 0.2 \% \text { and } \\
\text { overall savings reduced } \\
0.3 \% \text {. }\end{array}$ & \\
\hline 8 & Envelope & $\begin{array}{l}\text { How are 2nd and 3rd floor slab edges insulated. Many architectural } \\
\text { designs have the slab edge exposed to the air or treated with minimal } \\
\text { insulation that is less than the wall assembly R-value. }\end{array}$ & $\begin{array}{l}\text { Modeled wall values are } \\
\text { simplified to meet code and } \\
\text { improve on code. Some } \\
\text { jurisdictions do require slab } \\
\text { edge insulation and some } \\
\text { do apply it routinely } \\
\text { depending on the designers. }\end{array}$ & No action \\
\hline 9 & Envelope & $\begin{array}{l}\text { Is the slab edge modeled above the ground, exposed to the air or is the } \\
\text { slab edge buried and covered with dirt? }\end{array}$ & $\begin{array}{l}\text { Slab edge has an effective } \\
\text { F-factor consistent with } \\
\text { code. Losses from the slab } \\
\text { edge are typically very } \\
\text { modest. }\end{array}$ & No action \\
\hline 10 & Envelope & $\begin{array}{l}\text { Typical window seal is } 2.5 \mathrm{ft} \text {. and window height of 5-6 ft. or larger. } \\
\text { Getting window height correct will affect daylighting opportunities. }\end{array}$ & $\begin{array}{l}\text { Simulation has sill height } \\
\text { of } 3 \mathrm{ft} \text {. 5in, and window } \\
\text { height of } 4 \mathrm{ft} \text {. } 4 \text { in. so top of } \\
\text { window is very close to the } \\
\text { values cited in comment, } \\
\text { and have an impact on } \\
\text { daylighting. A review of } \\
\text { daylighting results indicated }\end{array}$ & No action \\
\hline
\end{tabular}




\begin{tabular}{|c|c|c|c|c|}
\hline No. & Category & Comment & PNNL Response & PNNL Action \\
\hline & & & $\begin{array}{l}\text { getting about } 80 \% \text { of the } \\
\text { potential daylighting } \\
\text { savings in the areas exposed } \\
\text { to side daylighting, so } \\
\text { further refinement would } \\
\text { not significantly improve } \\
\text { savings. expected to be } \\
\text { small for changing these } \\
\text { values. }\end{array}$ & \\
\hline 11 & Envelope & $\begin{array}{l}\text { Unrealistic, Architects will incorporate some form of main entry / } \\
\text { lobby that has a mult-floor (i.e. floor to roof) window section that will } \\
\text { be built out of curtain wall. Efficiency opportunities and cost- } \\
\text { effectiveness of curtain-wall is different than punched or storefront } \\
\text { windows. }\end{array}$ & $\begin{array}{l}\text { Model is simplified to allow } \\
\text { rapid modeling of changes } \\
\text { across many climates. } \\
\text { Window performance is } \\
\text { defined to code or } \\
\text { performance value without } \\
\text { specific regard to type of } \\
\text { construction. Will review } \\
\text { assumptions in cost- } \\
\text { effectiveness and consider } \\
\text { changing cost values to } \\
\text { reflect mix of curtain wall } \\
\text { and fixed windows. }\end{array}$ & $\begin{array}{l}\text { No further action. Reviewed } \\
\text { assumptions around type of } \\
\text { windows modeled. CBECS } \\
\text { data showed the bulk of } \\
\text { office buildings in this size } \\
\text { range use curtain wall or } \\
\text { storefront systems. } \\
\text { Performance and cost- } \\
\text { effectiveness based on } \\
\text { curtain wall. Generalization } \\
\text { of multi-story lobby facade } \\
\text { not demonstrated by } \\
\text { evidence other than } \\
\text { anecdotal, and the choice of } \\
\text { curtain wall performance and } \\
\text { overall window to wall ratio } \\
\text { of } 33 \% \text { considered to } \\
\text { adequately capture the } \\
\text { energy impact of the } \\
\text { fenestration in typical } \\
\text { medium office. }\end{array}$ \\
\hline 12 & Envelope & $\begin{array}{l}\text { To reach the standard SHGC and U-factor values, the EnergyPlus" } \\
\text { close match" SHGC and U-factor could be trued up by adjusting } \\
\text { model window area. }\end{array}$ & $\begin{array}{l}\text { Changing window areas } \\
\text { would distort SHGC and U- } \\
\text { value in different } \\
\text { proportions and would also } \\
\text { alter wall heat transfer to a } \\
\text { minor degree. The } \\
\text { closeness of the windows } \\
\text { selected to code values is } \\
\text { discussed in the report. No } \\
\text { further changes to try to } \\
\text { correct for this are being }\end{array}$ & No action \\
\hline
\end{tabular}




\begin{tabular}{|c|c|c|c|c|}
\hline No. & Category & Comment & PNNL Response & PNNL Action \\
\hline & & & made. & \\
\hline 13 & Envelope & $\begin{array}{l}\text { Does this imply that the U-values are not center of glass values and } \\
\text { that the U-values represent total window assembly (frame + edge of } \\
\text { glass + center of glass). }\end{array}$ & $\begin{array}{l}\text { Yes, modeled U-values are } \\
\text { overall U-values including } \\
\text { hypothetical framing. }\end{array}$ & No action \\
\hline 14 & Envelope & $\begin{array}{l}\text { What is the effective average infiltration value compared to design } \\
\text { values. Looking for load - does schedule and varying wind speed } \\
\text { drop this design value significantly in model? }\end{array}$ & $\begin{array}{l}\text { Infiltration is set to about } \\
0.2 \mathrm{ft}^{3} / \mathrm{min} / \mathrm{ft}^{2} \text { of exterior } \\
\text { area, is adjusted for wind } \\
\text { speed according to DOE-2 } \\
\text { formula and is scheduled at } \\
100 \% \text { during hours when } \\
\text { system(s) scheduled off and } \\
25 \% \text { when fan(s) run (these } \\
\text { values based on study at } \\
\text { PNNL as a follow on to } \\
\text { field data from NIST and } \\
90.1 \text { committee input). }\end{array}$ & No action \\
\hline 15 & Envelope & $\begin{array}{l}\text { What are the odds of getting a footnote explaining the difference } \\
\text { between assembly U-value and Recommended R-value. Why do I } \\
\text { need a R-13 batt ( } 0.077 \text { U-value) when the assembly requirement is } \\
\text { only } 0.124 \text { U-value? The point is steel-framing has large reduction of } \\
\text { effective R-value. Maybe this belongs in the baseline building } \\
\text { description. }\end{array}$ & $\begin{array}{l}\text { Does not seem necessary in } \\
\text { this technical background } \\
\text { report for an experienced } \\
\text { audience to explain a basic } \\
\text { principle. }\end{array}$ & No action. \\
\hline 16 & Envelope & $\begin{array}{l}\text { No look at the benefits of massing, loss opportunity? Many of the } \\
\text { commercial office buildings already use massing beyond your } \\
\text { assumed baseline and the benefits should be recognized if they are } \\
\text { designing with mass. I understand the energy cost-effectiveness may } \\
\text { not be the driver, but if they are already doing it for other reasons } \\
\text { (esthetics, durability, reduced maintenance), why not book some } \\
\text { savings. }\end{array}$ & $\begin{array}{l}\text { PNNL ran models with } 6 \text { in. } \\
\text { concrete wall added to } \\
\text { frame wall. Overall R- } \\
\text { value of wall increased for } \\
\text { concrete with insulation left } \\
\text { the same as with the metal } \\
\text { stud wall. Across all } \\
\text { climates, impact was about } \\
0.5 \% \text { improved energy } \\
\text { savings. At this modest } \\
\text { improvement in energy, } \\
\text { adding mass is unlikely to } \\
\text { be cost effective. As noted } \\
\text { above, CBECS data } \\
\text { suggested framed wall } \\
\text { significantly more common } \\
\text { now than mass wall. }\end{array}$ & No action \\
\hline 17 & Envelope & This would suggest table 3.4 only applies to punched windows, which & Advanced models being & Changed fenestration \\
\hline
\end{tabular}




\begin{tabular}{|c|c|c|c|c|}
\hline No. & Category & Comment & PNNL Response & PNNL Action \\
\hline & & $\begin{array}{l}\text { is a small percentage of the commercial construction market. Suggest } \\
\text { additional analysis and recommendations for curtain-wall and } \\
\text { storefront windows. }\end{array}$ & $\begin{array}{l}\text { changed to addendum bb } \\
\text { values for curtain wall. }\end{array}$ & $\begin{array}{l}\text { performance to curtain wall. } \\
\text { See response to question } 11 \\
\text { above. }\end{array}$ \\
\hline 18 & Envelope & $\begin{array}{l}\text { Good example on projection factor below. If higher windows are } \\
\text { evaluated (as suggested earlier), this projection factor may need to be } \\
\text { reduced, i.e. it's unlikely an architect would but a } 3 \mathrm{ft} .+ \text { overhang on a } \\
5.5 \mathrm{ft} \text {.high window. How would you treat or model the tall curtain- } \\
\text { wall assembly for shading overhangs? }\end{array}$ & $\begin{array}{l}\text { Window heights are } \\
\text { reasonably close to earlier } \\
\text { suggestion. Not changing } \\
\text { window heights as } \\
\text { discussed in response to } \\
\text { question on higher } \\
\text { windows. }\end{array}$ & No action \\
\hline 19 & Envelope & $\begin{array}{l}\text { As for the windows, we would suggest to consider better U-factors. In } \\
\text { Europe for example, following values are standard (and I guess in } \\
\text { Germany even mandatory): frame } 2.0 \ldots 2.2 \mathrm{~W} / \mathrm{m}^{2} \mathrm{~K} \text {, glass } 1.2 \\
\mathrm{~W} / \mathrm{m}^{2} \mathrm{~K}=>\text { Window } \sim 1.5 \mathrm{~W} / \mathrm{m}^{2} \mathrm{~K} \text { (note, Germany would be Climate } \\
\text { Zone 5). It's almost impossible to get windows with higher U-factors. }\end{array}$ & $\begin{array}{l}\text { Advanced models being } \\
\text { changed to addendum bb } \\
\text { values for curtain wall. }\end{array}$ & $\begin{array}{l}\text { Changed fenestration } \\
\text { performance to curtain wall. } \\
\text { See response to question } 11 \\
\text { above. }\end{array}$ \\
\hline 20 & Envelope & $\begin{array}{l}\text { We would also suggest to consider automatic shading controls, at least } \\
\text { for some climate zones. The idea is simply a variable SHGC and } \\
\text { adjustable daylight level. Here are some examples: } \\
\text { www.pacificshades.com. }\end{array}$ & $\begin{array}{l}\text { Will consider automatic } \\
\text { shading if } 50 \% \text { not reached. } \\
\text { Costly measure. }\end{array}$ & $\begin{array}{l}\text { Automatic shading was not } \\
\text { necessary to achieve } 50 \% \\
\text { savings with radiant systems. } \\
\text { This could be considered for } \\
\text { future work, particularly to } \\
\text { enhance the performance of } \\
\text { less costly HVAC systems. } \\
\text { Automatic shading systems } \\
\text { tend to be costly and require } \\
\text { maintenance, so would not } \\
\text { necessarily be among the } \\
\text { first priority high } \\
\text { performance energy } \\
\text { measures. }\end{array}$ \\
\hline 21 & Envelope & $\begin{array}{l}\text { A - One example, steel stud walls in the office can only be improved } \\
\text { by adding exterior sheathing. The cavity insulation is roughly derated } \\
\text { by } 50 \% \text { due to the steel thermal short circuiting. A } 2 \times 6 \text { steel stud wall } \\
\text { does not contribute much over a } 2 \times 4 \text { steel stud wall. Thus, the } \\
\text { challenge is to significantly improve the wall R-value without } \\
\text { increasing the wall thickness. }\end{array}$ & $\begin{array}{l}\text { Advance case includes } \\
\text { adding exterior rigid } \\
\text { insulation. }\end{array}$ & No action \\
\hline 22 & Envelope & $\begin{array}{l}\text { C - The } 90.1 \text { envelope subcommittee has spent considerable time } \\
\text { trying to incorporate continuous air barriers into the standard. This is } \\
\text { another item where advanced energy savings can be obtained. } \\
\text { Vestibules are another feature to reduce air infiltration loads. }\end{array}$ & $\begin{array}{l}\text { Continuous air barrier } \\
\text { savings not available and no } \\
\text { reasonable method to } \\
\text { estimate identified for this } \\
\text { study. }\end{array}$ & No action \\
\hline
\end{tabular}




\begin{tabular}{|c|c|c|c|c|}
\hline No. & Category & Comment & PNNL Response & PNNL Action \\
\hline 23 & General & $\begin{array}{l}\text { Typical office occupancy is } 7 \mathrm{am}-7 \mathrm{pm} \text {. It is unlikely HVAC will need } \\
\text { to run to midnight. I don't see a need to run HVAC after 7-8pm, 9pm } \\
\text { at the latest. I could see a high raise office running HVAC to } \\
\text { midnight, but not a 55K sq. ft. office. }\end{array}$ & $\begin{array}{l}\text { Scheduled operating hours } \\
\text { consistent with total hours } \\
\text { under CBECS data } \\
\text { (CBECS 2003). }\end{array}$ & No action \\
\hline 24 & General & Proven or accepted technology by end user? & $\begin{array}{l}\text { Technology for occupancy } \\
\text { sensor control of task } \\
\text { lighting and other plug } \\
\text { loads is commercially } \\
\text { available, and well not } \\
\text { pervasively used, is being } \\
\text { applied in buildings. }\end{array}$ & No action \\
\hline 25 & General & $\begin{array}{l}\text { EUIs look unrealistically low. I would expect the baselines to be } 60 \text { - } \\
80 \text { for average climates and up to } 90-100 \text { for extreme climates. Fatten } \\
\text { up the models. Factor in operational slop - people don't turn things } \\
\text { off. }\end{array}$ & $\begin{array}{l}\text { Baseline model EUIs are } \\
\text { intended to reflect buildings } \\
\text { that meet ASHRAE 90.1- } \\
\text { 2004, not buildings that } \\
\text { don't meet that standard. } \\
\text { Advanced case models are } \\
\text { expected to be } \\
\text { enhancements to an in } \\
\text { compliance building. } \\
\text { Determining what to } \\
\text { assume is not working } \\
\text { would create a lot of } \\
\text { arbitrary variation that may } \\
\text { impact the \% savings and } \\
\text { performance in unknown } \\
\text { ways. That said, attempts } \\
\text { to increase the EUIs } \\
\text { consistent with reasonable } \\
\text { design and operating } \\
\text { practice such as adjusting } \\
\text { heating setback within } \\
\text { comments made by the } 90.1 \\
\text { committee have been } \\
\text { implemented. }\end{array}$ & $\begin{array}{l}\text { Some adjustments were } \\
\text { made to the baseline } \\
\text { schedules and outside air. } \\
\text { Outside air ventilation was } \\
\text { increased based on a } \\
\text { calculation of using the } \\
\text { multiple zone and critical } \\
\text { zone rules in ASHRAE 62.1- } \\
2004 \text { Standard. EUI for } \\
\text { baseline increased to an } \\
\text { average of } 58 \text { kBtu/s.f./year } \\
\text { with } 48 \text { for the mildest } \\
\text { climate Los Angeles, and } 76 \\
\text { for the most extreme climate } \\
\text { Fairbanks. This is an } \\
\text { increase from the earlier } \\
\text { average of } 47 \text {. In addition, } \\
\text { an extraction of data from } \\
\text { CBECS (office, } 1990-2004 \text {, } \\
\text { 10,000-100,000 square feet, } \\
\text { packaged AC, no } \\
\text { incandescent lighting } \\
\text { provided } 19 \text { surveyed } \\
\text { buildings resulting in EUI of } \\
77 \text {. Adjusting this for } \\
\text { compliance with } 90.1-2004 \\
\text { vs } 1999 \text { (-14\% according to } \\
\text { ASHRAE) and an additional } \\
10 \% \text { for baseline close to } \\
\text { new, compliant performance, }\end{array}$ \\
\hline
\end{tabular}




\begin{tabular}{|c|c|c|c|c|}
\hline No. & Category & Comment & PNNL Response & PNNL Action \\
\hline & & & & $\begin{array}{l}\text { results in an EUI of } 58 \text {, } \\
\text { suggesting that the average } \\
\text { of } 58 \text { now calculated is } \\
\text { reasonable given the goals of } \\
\text { the TSD work. }\end{array}$ \\
\hline 26 & General & $\begin{array}{l}\text { Here are some suggestions of measures, which could be technical } \\
\text { and/or organizational:• Radiant heating and cooling• Chilled beams• } \\
\text { Natural / hybrid ventilation (at least for some climate zones)• } \\
\text { Nighttime ventilation• Lighting control for different zones (perimeter } \\
\text { / core)• Move janitorial activities from evening/night to regular work } \\
\text { time (and adjust schedules, accordingly)• Sophisticated control } \\
\text { systems and even more important: sophisticated control strategies } \\
\text { (adjustment of setpoints, schedules, etc.)• Geothermal energy (directly } \\
\text { for cooling in combination with radiant cooling)• Cogeneration (e.g., } \\
\text { in combination with absorption chillers)• Fuel cells??? }\end{array}$ & $\begin{array}{l}\text { * Radiant heating and } \\
\text { cooling with DOAS in } \\
\text { advanced. *Chilled beams } \\
\text { primarily convective, } \\
\text { require colder water than } \\
\text { radiant, may have forced air } \\
\text { so may not save as much as } \\
\text { radiant. *Natural ventilation } \\
\text { not effective in many } \\
\text { climates and added cost } \\
\text { high for hybrid systems. } \\
\text { *Nighttime ventilation } \\
\text { considered if missing } 50 \% \text {. } \\
\text { *Lighting controls include } \\
\text { different \% savings in } \\
\text { different types of spaces, } \\
\text { with daylighting in } \\
\text { perimeter. *Reducing } \\
\text { evening janitorial services } \\
\text { if missing } 50 \% \text {, and } \\
\text { possible for future work, } \\
\text { although an operator issue } \\
\text { not a design issue. } \\
\text { *Simulation includes added } \\
\text { controls for VAV case, see } \\
\text { TSD. *geothermal (GSHP) } \\
\text { is being explored for other } \\
\text { TSD work. Limited } \\
\text { application in dense urban } \\
\text { areas due to thermal } \\
\text { contamination. } \\
\text { *Cogeneration and fuel } \\
\text { cells reduce energy and } \\
\text { carbon primarily if } \\
\text { renewable fuel source, and } \\
\text { part of reduction beyond } \\
50 \% \text { goal on path to net }\end{array}$ & $\begin{array}{l}50 \% \text { goal met for radiant } \\
\text { system with DOAS case. } \\
\text { Budget and schedule } \\
\text { limitations precluded } \\
\text { analysis of additonal } \\
\text { measures. Will recommend } \\
\text { future work on night } \\
\text { ventilation, consideration of } \\
\text { reducing evening hours for } \\
\text { shifting janitorial towards } \\
\text { working hours, occupancy } \\
\text { sensor control of HVAC } \\
\text { setpoints/damper positions, } \\
\text { inclusion of on-site } \\
\text { generation including co- } \\
\text { generation and fuel cells as } \\
\text { well as solar opportunities. }\end{array}$ \\
\hline
\end{tabular}




\begin{tabular}{|c|c|c|c|c|}
\hline No. & Category & Comment & PNNL Response & PNNL Action \\
\hline & & & zero. & \\
\hline 28 & HVAC & $\begin{array}{l}\text { This isn't realistic. Cost of duct work would suggest two units that } \\
\text { serve } 1 / 2 \text { the floor area on all three floors, i.e. north/south or east /west } \\
\text { zone orientation. Common supply and return air ducting shaft / chase } \\
\text { would run from roof to the } 1 \text { st floor. }\end{array}$ & $\begin{array}{l}\text { Simplification of systems } \\
\text { done to facilitate modeling. } \\
\text { Not able to revise geometry } \\
\text { of model at this point to } \\
\text { accomadate re-zoning to } \\
\text { east-west systems. }\end{array}$ & $\begin{array}{l}\text { Include recommendation for } \\
\text { future work to explore east } \\
\text { west and or/core perimeter } \\
\text { configurations }\end{array}$ \\
\hline 29 & HVAC & $\begin{array}{l}\text { This may be the ASHRAE Std } 55 \text { recommendation, but likely not } \\
\text { maintained in the real would. If you want to maintain a } 5 \mathrm{~F} \text { deadband I } \\
\text { suggest other temperature ranges }(68 \mathrm{H} / 73 \mathrm{C}, 69 \mathrm{H} / 74 \mathrm{C}, 70 \mathrm{H} / 75 \mathrm{C}) \text { are } \\
\text { assigned for different climate zones. The cooling setpoint in humid } \\
\text { climates is generally lower ( } 72 \mathrm{~F} \text { ) in an effort to control humidity. }\end{array}$ & $\begin{array}{l}\text { For consistency across } \\
\text { models and with } 5 \text { degree } \\
\text { deadband in } 90.1 \text { setpoints } \\
\text { left at original settings. No } \\
\text { data available to set any } \\
\text { different values for different } \\
\text { climates and buildings in } \\
\text { medium office category. }\end{array}$ & No action \\
\hline 30 & HVAC & $\begin{array}{l}\text { Check for load data, (i.e. Fan - CFM/Sqft, Cooling - Sqft/Ton, } \\
\text { Heating - BTU/Sqft) is this information going to be presented. }\end{array}$ & $\begin{array}{l}\text { Loads information not } \\
\text { provided at this time. }\end{array}$ & No action \\
\hline 31 & HVAC & $\begin{array}{l}\text { Another approach I have seen is to use ASHRAE extreme weather for } \\
\text { design day and apply a smaller or no sizing factor. }\end{array}$ & $\begin{array}{l}\text { Part load hours considered } \\
\text { with stated sizing and } \\
\text { appears reasonable } \\
\text { distribution. }\end{array}$ & No action \\
\hline 32 & HVAC & $\begin{array}{l}\text { I recommend a section describing the air distribution system: } \\
\text { materials (hard duct vs. flex duct) duct sizing \& velocities (target } \\
\text { pressure drop per } 100 \text { ' for main and run out legs), type of VAV } \\
\text { terminal units, return plenum or ducted return, air diffusers, etc. }\end{array}$ & $\begin{array}{l}\text { Systems are not fully } \\
\text { designed, and design } \\
\text { elements suggested are } \\
\text { incorporated in broader } \\
\text { factors such as static } \\
\text { pressure that are shown in } \\
\text { the TSD report. }\end{array}$ & No action \\
\hline 33 & HVAC & $\begin{array}{l}\text { More importantly than COP is the part load efficiency assigned in } \\
\text { model. What set of efficiency curves are used in your analysis? Is } \\
\text { there any accounting for de-gradation in equipment performance that } \\
\text { is common with packaged rooftop equipment? }\end{array}$ & $\begin{array}{l}\text { Include identified } \\
\text { performance curves with } \\
\text { any more detailed system } \\
\text { descriptions adressed under } \\
\text { above comment. Study } \\
\text { reflects new building } \\
\text { performance and does not } \\
\text { try to capture degradation } \\
\text { of systems over time. Such } \\
\text { a modeling approach has }\end{array}$ & $\begin{array}{l}\text { Performance curves included } \\
\text { in Appendix A. Mention of } \\
\text { considering long-term } \\
\text { performance, and } \\
\text { maintenance and operations } \\
\text { is included in the } \\
\text { recommendations for future } \\
\text { work. }\end{array}$ \\
\hline
\end{tabular}




\begin{tabular}{|c|c|c|c|c|}
\hline No. & Category & Comment & PNNL Response & PNNL Action \\
\hline & & & $\begin{array}{l}\text { not been generally adopted } \\
\text { and would require } \\
\text { significant changes in } \\
\text { modeling approach with the } \\
\text { need to collect significant } \\
\text { industry information on } \\
\text { experience in the field. } \\
\text { There may be an increased } \\
\text { relative savings from high } \\
\text { performance equipment in } \\
\text { the advanced case caused } \\
\text { by higher quality equipment } \\
\text { but this would likely be } \\
\text { offset by operator changes } \\
\text { due to unfamiliarity with } \\
\text { newer systems. }\end{array}$ & \\
\hline 34 & HVAC & (fan power ratio) & agree to change in report & No action \\
\hline 35 & HVAC & With or without gas heat 0.2 credit? & $\begin{array}{l}\text { Text discusses } 0.2 \text { credit for } \\
\text { gas (non-electric) heat. } \\
\text { Values in tables are with } \\
\text { credit, except } 240,000 \text { to } \\
760,000 \text { Btuh. }\end{array}$ & $\begin{array}{l}\text { Fixed value for } 240-760 \\
\text { kBtuh. }\end{array}$ \\
\hline 36 & HVAC & $\begin{array}{l}\text { Like cooling, more importantly than AFUE and Ec is the part-load } \\
\text { efficiency assigned in model. What set of efficiency curves are used } \\
\text { in your analysis? }\end{array}$ & $\begin{array}{l}\text { Include identified } \\
\text { performance curves with } \\
\text { any more detailed system } \\
\text { descriptions adressed under } \\
\text { above comment. }\end{array}$ & $\begin{array}{l}\text { Part load performance curves } \\
\text { provided in Appendix A }\end{array}$ \\
\hline 37 & HVAC & $\begin{array}{l}\text { Does this imply that the gas furnace part-load efficiency curve is hold } \\
\text { fixed at } 100 \% \text { and a constant } 78 \% \text { value is used. I recently modeled a } \\
\text { gas furnace in a DOE2 model and the default curves resulted in an } \\
\text { annual efficiency of } 65 \% \text {, which I thought was unrealistically low. }\end{array}$ & $\begin{array}{l}\text { Include identified } \\
\text { performance curves with } \\
\text { more detailed system } \\
\text { descriptions addressed } \\
\text { under above comment. }\end{array}$ & $\begin{array}{l}\text { Part load performance curves } \\
\text { provided in Appendix A }\end{array}$ \\
\hline 38 & HVAC & $\begin{array}{l}\text { With one RTU (rooftop unit) per floor I can see you would have units } \\
\text { under 20,000 sq. ft. But if there was only two units (as previously } \\
\text { suggested) I suspect all units would be over } 20,000 \mathrm{cfm} \text {. }\end{array}$ & $\begin{array}{l}\text { Simulation will continue to } \\
\text { use three units because } \\
\text { building size will vary in } \\
\text { reality, not just at modeled } \\
\text { square footage, some units } \\
\text { will be less than } 20,000 \\
\text { cfm. The fan power varies } \\
\text { in the model by climate }\end{array}$ & No action \\
\hline
\end{tabular}




\begin{tabular}{|c|c|c|c|c|}
\hline No. & Category & Comment & PNNL Response & PNNL Action \\
\hline & & & $\begin{array}{l}\text { zone according to airflow } \\
\text { and the code allowed } \\
\text { power. This is reasonable } \\
\text { given the range of building } \\
\text { sizes and climates } \\
\text { represented by the analysis. }\end{array}$ & \\
\hline 39 & HVAC & $\begin{array}{l}\text { This would represent good design practice in custom AHU (air } \\
\text { handling unit) that uses a plug fan. If Packaged RTUs are using plug } \\
\text { fans, I would suspect an efficiency range of } 55-60 \% \text { is more realistic. } \\
\text { I suggest looking at vendor product data. }\end{array}$ & $\begin{array}{l}\text { Fan efficiency values and } \\
\text { assumption of a } 90 \% \text { ratio } \\
\text { for fan bhp to design are } \\
\text { both worth considering } \\
\text { further. If fan efficiency } \\
\text { were lower, and ratio of bhp } \\
\text { to nameplate were lower, } \\
\text { allowed static would be } \\
\text { lower as well. Note that } \\
\text { model includes a supply fan } \\
\text { only, so any relief fan or } \\
\text { return fan static is not } \\
\text { accounted for directly, and } \\
\text { the pressure drop for this is } \\
\text { included. }\end{array}$ & $\begin{array}{l}\text { Determined that effective fan } \\
\text { power is set at appropriate } \\
\text { level for code baseline. } \\
\text { Baseline is set to just meet } \\
90.1-2004 \text {. }\end{array}$ \\
\hline 40 & HVAC & $\begin{array}{l}\text { These pressures look excessive. Can packaged RTUs even be selected } \\
\text { and built that can meet these pressures? These pressures would } \\
\text { suggest high external static pressure and horrific duct design. }\end{array}$ & See response to 40 above & See response to 40 above \\
\hline 41 & HVAC & $\begin{array}{l}\text { Assuming a minimum design airflow of } 1 \mathrm{cfm} / \mathrm{sq} \text {. ft., this ventilation } \\
\text { rate is low }<10 \% \text {. From a practical standpoint I see most designs } \\
\text { coming in at } 20 \% \text { outside air (OSA). Designers often use } 10 \text { people } \\
\text { per } 1000 \text { sq. ft. (egress level) in office buildings even though actual } \\
\text { occupancy is closer to } 5 \text { per } 1000 \text { sq. ft. Remember there are high } \\
\text { occupancy areas (conference rooms) which will define the critical } \\
\text { ventilation zone that will also drive the need for higher OSA rates. }\end{array}$ & $\begin{array}{l}\text { Reviewing outside air is } \\
\text { appropriate. }\end{array}$ & $\begin{array}{l}\text { Changed to } 62.1-2004 \\
\text { calculation of outside air for } \\
\text { multiple-zone system rules } \\
\text { which account for spaces } \\
\text { with different uses such as } \\
\text { conference rooms. Increased } \\
\text { outside air as a result about } \\
20 \% \text { above earlier model. }\end{array}$ \\
\hline 42 & HVAC & $\begin{array}{l}\text { Remember excessive ventilation is good for us, at least according to } \\
\text { LEED, who gives an additional point for excessive ventilation. }\end{array}$ & OK--but modeling to code. & No action \\
\hline 43 & HVAC & $\begin{array}{l}\text { I think it is your only hope at getting to } 50 \% \text {. Air is an inefficient } \\
\text { means of heat transfer. Radiant water systems are the way of the } \\
\text { future. }\end{array}$ & $\begin{array}{l}\text { We are modeling radiant } \\
\text { systems. }\end{array}$ & No action \\
\hline 44 & HVAC & $\begin{array}{l}\text { Is there a case of double counting here? I thought one of the ways } \\
\text { RTU efficiency (EER) was improved was the use of premium }\end{array}$ & $\begin{array}{l}\text { The efficiency ratings are } \\
\text { based on minimal static, so }\end{array}$ & No action \\
\hline
\end{tabular}




\begin{tabular}{|c|c|c|c|c|}
\hline No. & Category & Comment & PNNL Response & PNNL Action \\
\hline & & efficient motor by the manufacturers. & $\begin{array}{l}\text { the benefit of motor } \\
\text { efficiency is greatly } \\
\text { understated. It is } \\
\text { reasonable to take credit for } \\
\text { the effect of the improved } \\
\text { motor efficiency on fan } \\
\text { energy. }\end{array}$ & \\
\hline 45 & HVAC & TEFC (totally enclosed fan) vs. ODP (open drip-proof)? & $\begin{array}{l}\text { TEFC, report indicates this } \\
\text { at the end of 2.6.6. }\end{array}$ & No action \\
\hline 46 & HVAC & $\begin{array}{l}\text { Are economizers recommended for all RTU sizes or will there be a } \\
\text { size cut off, i.e. } 3 \text { tons? }\end{array}$ & $\begin{array}{l}\text { Model capacities all greater } \\
\text { than } 6 \text { tons, so including } \\
\text { economizers for all units. } \\
\text { Designers should know to } \\
\text { exclude from units that are } \\
\text { too small to have effective } \\
\text { economizers. }\end{array}$ & No action \\
\hline 47 & HVAC & $\begin{array}{l}\text { What is the assumed supply air temperature at the } 45 \mathrm{~F} \text { OSA cut out } \\
\text { temperature? }\end{array}$ & $\begin{array}{l}\text { Heat recovery modeling } \\
\text { inputs in final TSD } \\
\text { description of DOAS } \\
\text { section } 4.4 .1 \text { and in the } \\
\text { alternative VAV case in } \\
\text { section } 4.5\end{array}$ & No action \\
\hline 48 & HVAC & $\begin{array}{l}\text { What is your supply air to return air ratio for the listed efficiencies? } \\
\text { Supply airflow is generally higher than return airflow since air is lost } \\
\text { for building pressurization and toilet or other exhaust is generally not } \\
\text { recovered. How is efficiency during cold weather down graded to } \\
\text { account for exhaust air frosting / heat exchanger icing up. Is the wheel } \\
\text { slowed up or bypassed? }\end{array}$ & See above question 47 & No action \\
\hline 49 & HVAC & $\begin{array}{l}\text { Don't understand this. Is direct evaporative cooling excluded, if so } \\
\text { why? I would encourage you to look at indirect/direct cooling with a } \\
\text { small direct expansion (DX) coil sized for latent heat removal to } \\
\text { control humidity during the unusual hot and humid days. To limit } \\
\text { build up of humidity, operate in } 100 \% \text { OSA mode with no return air } \\
\text { re-circulated }\end{array}$ & $\begin{array}{l}\text { Indirect/direct is only } \\
\text { applicable to a limited set } \\
\text { of the drier climate zones. } \\
\text { EnergyPlus modeling of } \\
\text { indirect/direct is also not } \\
\text { functioning. Will pursue } \\
\text { modeling indirect only for } \\
\text { some climate zones. }\end{array}$ & $\begin{array}{l}\text { Indirect evaporative cooling } \\
\text { modeled for climate zones } \\
\text { 2B, 3B, 4B and 5B for the } \\
\text { VAV alternative advanced } \\
\text { case. Not needed for radiant } \\
\text { system advanced case to } \\
\text { meet savings target and } \\
\text { because of added cost, is not } \\
\text { included for that case. }\end{array}$ \\
\hline 50 & HVAC & Don't understand reference to three evaporative coolers. & $\begin{array}{l}\text { This refers to the three } \\
\text { packaged VAV units, each }\end{array}$ & No action \\
\hline
\end{tabular}




\begin{tabular}{|c|c|c|c|c|}
\hline No. & Category & Comment & PNNL Response & PNNL Action \\
\hline & & & $\begin{array}{l}\text { with a separate evaporative } \\
\text { cooler. }\end{array}$ & \\
\hline 51 & HVAC & What is the assumed pressure drop on the primary air side? & $\begin{array}{l}\text { Reviewing indirect } \\
\text { evaporative cooling inputs }\end{array}$ & $\begin{array}{l}0.8 \text { pressure drop on primary } \\
\text { air side. Now included in } \\
\text { TSD }\end{array}$ \\
\hline 52 & HVAC & $\begin{array}{l}\text { Aren't there zones that will have ventilation demands that will require } \\
\text { higher terminal unit box minimum airflow settings, i.e., conference } \\
\text { rooms? }\end{array}$ & $\begin{array}{l}\text { Model is being corrected to } \\
\text { set minimums so that } \\
\text { outside air requirements are } \\
\text { met. }\end{array}$ & $\begin{array}{l}\text { See response to question } 41 \\
\text { above }\end{array}$ \\
\hline 53 & HVAC & $\begin{array}{l}\text { Evaluate getting rid of gas hot water heater. Tank and piping heat } \\
\text { losses and associated circulation pump energy probably exceeds } \\
\text { actual hot water load. }\end{array}$ & $\begin{array}{l}\text { Piping runs are small and } \\
\text { localized to core restrooms } \\
\text { and break rooms in many } \\
\text { cases for this size and type } \\
\text { of building. Service water } \\
\text { heating is a small energy } \\
\text { usage. Will describe in } \\
\text { report potential benefit of } \\
\text { on-demand water heaters. } \\
\text { Advanced case includes } \\
\text { condensing water heater, so } \\
\text { additional savings from on- } \\
\text { demand are not substantial. }\end{array}$ & $\begin{array}{l}\text { Added mention of on- } \\
\text { demand water heaters as } \\
\text { alternative to serve } \\
\text { peripheral loads to advanced } \\
\text { case in TSD. }\end{array}$ \\
\hline 54 & HVAC & $\begin{array}{l}\text { Recommend switch from all air systems to water based systems for } \\
\text { heating and cooling. This could be radiant slab heating and cooling, } \\
\text { chilled beams (passive/active), chilled ceilings, etc. }\end{array}$ & $\begin{array}{l}\text { Radiant heating and cooling } \\
\text { being modeled for TSD. }\end{array}$ & No action \\
\hline 55 & HVAC & $\begin{array}{l}\text { The HVAC options explored do not include geothermal (or ground } \\
\text { source) heat pumps. While not applicable to all climates, it certainly } \\
\text { would be in many. }\end{array}$ & $\begin{array}{l}\text { Because of the difficulties } \\
\text { in modeling multiple } \\
\text { system types, and the time } \\
\text { available for this project } \\
\text { ground source heat pumps } \\
\text { were not modeled at this } \\
\text { point. An effort is } \\
\text { underway to develop an } \\
\text { effective working model for } \\
\text { ground source heat pumps } \\
\text { under the Lodging TSD } \\
\text { development effort. }\end{array}$ & No action \\
\hline 56 & HVAC & $\begin{array}{l}\text { B - Another example is the HVAC systems. Should other equipment } \\
\text { types be considered for the advanced cases? }\end{array}$ & $\begin{array}{l}\text { Radiant heating and cooling } \\
\text { with DOAS being modeled }\end{array}$ & No action \\
\hline
\end{tabular}




\begin{tabular}{|c|c|c|c|c|}
\hline No. & Category & Comment & PNNL Response & PNNL Action \\
\hline & & & $\begin{array}{l}\text { for TSD. Insufficient time } \\
\text { to consider other options, } \\
\text { and see above on ground } \\
\text { source heat pumps. Note } \\
\text { that ground source systems } \\
\text { may be inherently limited } \\
\text { in dense urban settings } \\
\text { because the ground and/or } \\
\text { groundwater may become } \\
\text { thermally contaminated by } \\
\text { adjacent systems }\end{array}$ & \\
\hline 57 & HVAC & $\begin{array}{l}\text { D - Thermal comfort is never addressed when assessing the benefits } \\
\text { of advanced buildings. What are the energy savings from changing } \\
\text { thermostat set point temperature while still maintaining the same or } \\
\text { possibly even providing the thermal comfort? }\end{array}$ & $\begin{array}{l}\text { Varying air setpoints while } \\
\text { reducing thermal gains and } \\
\text { losses with air movement } \\
\text { and different radiant heat } \\
\text { transfer from exposed } \\
\text { surfaces such as the interior } \\
\text { of windows ( through lower } \\
\text { U-value glazing) is a good } \\
\text { topic for future work. } \\
\text { Radiant systems are } \\
\text { recommended as the } \\
\text { primary HVAC system and } \\
\text { can provide comfort at a } \\
\text { larger range of air } \\
\text { temperatures. }\end{array}$ & $\begin{array}{l}\text { The radiant system model } \\
\text { accounted to some degree for } \\
\text { comfort at a larger range of } \\
\text { air temperature since the } \\
\text { radiant system can achieve } \\
\text { the same level of operative } \\
\text { temperature at a lower air } \\
\text { temperature. Therefore, in } \\
\text { the advanced models, the } \\
\text { thermostat setpoint was } \\
\text { increased from } 75^{\circ} \mathrm{F}\left(24^{\circ} \mathrm{C}\right) \\
\text { to } 77^{\circ} \mathrm{F}\left(25^{\circ} \mathrm{C}\right) \text { for cooling } \\
\text { and decreased from } 70^{\circ} \mathrm{F} \\
\left(21^{\circ} \mathrm{C}\right) \text { to } 67^{\circ} \mathrm{F}\left(19.5^{\circ} \mathrm{C}\right) \text { for } \\
\text { heating. }\end{array}$ \\
\hline 58 & Lighting & $\begin{array}{l}\text { How is task lighting that is common to modular office furniture } \\
\text { accounted for, i.e. additional } 0.2 \text { watts/sq. } \mathrm{ft} \text {. }\end{array}$ & $\begin{array}{l}\text { ASHRAE } 90.1 \text { included } \\
\text { task lighting in the allowed } \\
\text { lighting power density } \\
\text { limits, and this is } \\
\text { incorporated in the model. }\end{array}$ & No action \\
\hline 59 & Lighting & $\begin{array}{l}\text { Egress lighting levels have been creeping up. I did a design review on } \\
\text { one building and egress lighting was } 20 \% \text { of normal lighting density. } \\
\text { A } 10 \% \text { egress lighting level would be more realistic. Actual metering } \\
\text { records by Eugene Water and Electric Board demonstrated } \\
\text { unoccupied load factors of } 40 \% \text { associated with lighting and } \\
\text { equipment loads. Remember to account for people leaving lights and } \\
\text { equipment on during unoccupied periods. }\end{array}$ & $\begin{array}{l}\text { Baseline model changed to } \\
15 \% \text { schedulled on lighting } \\
\text { during off hours to account } \\
\text { for egress lighting, task } \\
\text { lighitng and other lighting } \\
\text { left on for at least part of } \\
\text { the unoccupied hours. }\end{array}$ & No action \\
\hline 60 & Lighting & $\begin{array}{l}\text { This may be a reasonable number for general office use, but the } \\
\text { electronic / server room energy needs to be factored in. Somewhere in }\end{array}$ & $\begin{array}{l}\text { Electrical equipment loads } \\
\text { have been reviewed against }\end{array}$ & No action \\
\hline
\end{tabular}




\begin{tabular}{|c|c|c|c|c|}
\hline No. & Category & Comment & PNNL Response & PNNL Action \\
\hline & & $\begin{array}{l}\text { the building there will be a main electronics / server room with } \\
\text { additional load, i.e. uninterruptible power supply, phone switch, } \\
\text { networking gear, security electronics, storage drives, back up servers, } \\
\text { Liebert AC system, etc. }\end{array}$ & $\begin{array}{l}\text { available literature. Some } \\
\text { additions for small } \\
\text { appliances which can } \\
\text { include chargers and routers } \\
\text { and other distributed } \\
\text { networking gear were } \\
\text { added. Overall power } \\
\text { density, operating schedule } \\
\text { and resulting energy usage } \\
\text { per square foot are } \\
\text { consistent with available } \\
\text { information. }\end{array}$ & \\
\hline 61 & Lighting & $\begin{array}{l}\text { Low, it is a challenge for designers to reach this level. For some } \\
\text { reason there is an impression that corridors needs to be light and } \\
\text { bright. I have seen cases where there is more LPD in the corridor than } \\
\text { the office workspace. I see corridors having at least } 0.8 \mathrm{~W} / \mathrm{sq} . \mathrm{ft} \text {. in } \\
\text { the baseline and the goal could be } 0.5 \mathrm{~W} / \mathrm{sq} \text {. } \mathrm{ft} \text {. }\end{array}$ & $\begin{array}{l}\text { Modeling to ASHRAE } \\
90.1-2004 \text { for baseline. } \\
\text { Designers are working } \\
\text { towards this value, and are } \\
\text { implementing this in some } \\
\text { buildings. }\end{array}$ & No action \\
\hline 62 & Lighting & High number & $\begin{array}{l}\text { Advanced model reduced } \\
\text { overall to } 0.76 \mathrm{~W} / \mathrm{sq} . \mathrm{ft} . \\
\text { Providing updated table in } \\
\text { report. }\end{array}$ & $\begin{array}{l}\text { Final advanced case includes } \\
0.64 \text { W/s.f. for active storage } \\
\text { based on a lighting layout } \\
\text { from the Lighting Design } \\
\text { Lab in Seattle. }\end{array}$ \\
\hline 63 & Lighting & It would be disappointing if this value couldn't be reduced. & see above & $\begin{array}{l}\text { see above, lobby now at } 1.09 \\
\text { W/s.f. }\end{array}$ \\
\hline 64 & Lighting & $\begin{array}{l}\text { I thought code implied that sweep control was limited to common } \\
\text { areas and not individual rooms, i.e., private offices, restrooms, } \\
\text { storage, elec/mech rooms. }\end{array}$ & $\begin{array}{l}90.1-2004 \text { requires a } \\
\text { minimum of sweep in all of } \\
\text { these areas, and occupancy } \\
\text { sensors in some enclosed } \\
\text { areas. }\end{array}$ & No action \\
\hline 65 & Lighting & $\begin{array}{l}\text { Most storage rooms have wall switches. They may not be turned off } \\
\text { during the day, but generally are turned off at night by janitorial staff. }\end{array}$ & $\begin{array}{l}\text { Manual switching may or } \\
\text { may not provide savings. } \\
90.1-2004 \text { requires at least } \\
\text { sweep. Occupancy sensors } \\
\text { modeled to improve on } \\
\text { sweep. }\end{array}$ & No action \\
\hline 66 & Lighting & I don't see stairway lighting being switched off - code egress issues. & $\begin{array}{l}\text { Stairs identified as } 2 \% \text { of } \\
\text { area so minimal impact } \\
\text { either way. Stairs can be }\end{array}$ & No action \\
\hline
\end{tabular}




\begin{tabular}{|c|c|c|c|c|}
\hline No. & Category & Comment & PNNL Response & PNNL Action \\
\hline & & & $\begin{array}{l}\text { turned off with fail on } \\
\text { occupancy sensor controls } \\
\text { in some jurisdictions. } \\
\text { Stairs are not exempted } \\
\text { from } 90.1 \text { requirement for } \\
\text { sweep control. }\end{array}$ & \\
\hline 67 & Lighting & $\begin{array}{l}\text { Even those daylighting designs with a lot of intentional design (added } \\
\text { daylight windows, overhangs, light shelves, etc) there is an issue with } \\
\text { achieving modeled savings. Even with the best of daylighting designs } \\
\text { there is a percentage of time the blinds get adjusted downward to } \\
\text { reduce glare. Modeled savings should be discounted to account for the } \\
\text { blind usage, i.e., link to weather file during sunny days. Daylighting } \\
\text { in the east and west exposures shouldn't even be tried, south is doable } \\
\text { if done right and the north orientation generally has a high probability } \\
\text { of success. Without any special daylighting design (increased window } \\
\text { height, overhangs, light shelves, etc) getting light into an open office } \\
\text { area with systems furniture ( } 5 \mathrm{ft} \text {. high walls) will be difficult. }\end{array}$ & $\begin{array}{l}\text { Daylighting with side } \\
\text { daylighting is possible and } \\
\text { applied in buildings. } \\
\text { Simulation assumes a } \\
\text { careful design of } \\
\text { daylighting and estimates a } \\
\text { reasonable potential savings } \\
\text { for such a design. The } \\
\text { savings are not optimized. } \\
\text { Obstacles raised in } \\
\text { comment can and should be } \\
\text { overcome as much as } \\
\text { possible to achieve } \\
\text { important and possible } \\
\text { daylighting savings. }\end{array}$ & $\begin{array}{l}\text { Simulation of daylighting } \\
\text { and glare control is an area } \\
\text { recommended for further } \\
\text { development. Savings } \\
\text { results from current models } \\
\text { are a reasonable fraction of } \\
\text { the lighting energy in the } \\
\text { daylit areas. }\end{array}$ \\
\hline 68 & Lighting & $\begin{array}{l}\text { Suggest clarifying which lights will be turned off at midnight to } 6 \text { AM } \\
\text { and which lights will remain on but at a reduced level. Does the } \\
\text { proposed analysis assume a dark building between midnight and } 6 \text { am, } \\
\text { if so this isn't realistic. There are esthetics, code safety and security } \\
\text { issues which warrant some lighting to remain on }\end{array}$ & $\begin{array}{l}\text { Baseline lighting schedule } \\
\text { now at } 15 \% \text { for unoccupied } \\
\text { hours, and Advanced } \\
\text { lighting schedule at } 5 \% \text {. } \\
\text { Difference based on } \\
\text { occupancy controls vs. } \\
\text { sweep, better egress } \\
\text { lighting design, and some } \\
\text { use of security lock-out so } \\
\text { that in some buildings, all } \\
\text { of the lights can be turned } \\
\text { off. }\end{array}$ & No action \\
\hline 69 & Lighting & $\begin{array}{l}\text { On parking lot lighting, an option not explored is bi-level lighting. In } \\
\text { an installation with which I am familiar, each light fixture can operate } \\
\text { at two lighting levels. Full lighting would produce levels such as } \\
\text { those in your advanced case. A reduced level would kick in by a time } \\
\text { clock for generally unoccupied times. The lighting can be brought up } \\
\text { to full level during off-hours by one of two means: a switch inside the } \\
\text { office allows someone exiting the building to raise the lighting for, } \\
\text { say, } 15 \text { minutes while they leave the building; alternatively, a pressure }\end{array}$ & $\begin{array}{l}\text { Changed to } 10 \% \text { minimum } \\
\text { 1am to } 6 \text { am }\end{array}$ & No action \\
\hline
\end{tabular}




\begin{tabular}{|c|c|c|c|c|}
\hline No. & Category & Comment & PNNL Response & PNNL Action \\
\hline & & $\begin{array}{l}\text { mat at the entrance to the lot raise the level for some period of time } \\
\text { when a car enters. }\end{array}$ & & \\
\hline 70 & Lighting & $\begin{array}{l}\text { Are there any canopies at the entries? I would have assumed at least a } \\
50 \text { sq. ft. canopy at each main entry }\end{array}$ & $\begin{array}{l}\text { Exterior lighting values } \\
\text { allowed by } 90.1-2004 \text { are } \\
\text { likely higher than for real } \\
\text { design, so no additional } \\
\text { lighting needs to be added. }\end{array}$ & No action \\
\hline 71 & Lighting & $\begin{array}{l}\text { Each parking spot occupies } 405 \mathrm{ft}^{2} \text {. How was this determined? A } \\
\text { typical stall is } 18 \mathrm{x} 9 \mathrm{ft} \text {. Are you including some of the drive? }\end{array}$ & $\begin{array}{l}\text { Values from } 90.1 \text { Lighting } \\
\text { sub-committee }\end{array}$ & No action \\
\hline 72 & Lighting & $\begin{array}{l}\text { A number of changes on the lighting design. With those changes, LPD } \\
\text { reduced from } 0.88 \text { to } 0.85 \mathrm{~W} / \mathrm{ft}^{2} \text {. }\end{array}$ & Now reduced to $0.76 \mathrm{~W} / \mathrm{ft}^{2}$ & No action \\
\hline 73 & Lighting & $\begin{array}{l}\text { What is the assumption of how much of the open plan office is within } \\
15 \mathrm{ft} \text { ? What saving are you assuming from daylighting?? }\end{array}$ & $\begin{array}{l}\text { See final TSD Section } \\
\text { 4.2.1.4 }\end{array}$ & No action \\
\hline 74 & Lighting & $\begin{array}{l}\text { Will the exterior lighting control cause the site to be completely dark? } \\
\text { This seems a little extreme. Maybe leave } 10 \% \text { of the lights on. }\end{array}$ & $\begin{array}{l}\text { Changed to } 10 \% \text { minimum } \\
1 \text { AM to } 6 \text { PM }\end{array}$ & No action \\
\hline 75 & Lighting & $\begin{array}{l}\text { I would argue that you have over estimated the office station floor } \\
\text { area. If "Table } 3.5 \text {. Lighting power density calculation for the } \\
\text { advanced case" shows that } 16 \% \text { of the space is open office and } 25 \% \text { is } \\
\text { private office, is not the total office station space area ( } 54,000 \mathrm{sq} \text {. } \\
\mathrm{ft} . * 0.41=22140 \text { sq. } \mathrm{ft} \text {.) and a private office is larger than } 100 \mathrm{sq} \text {. } \mathrm{ft} \text {. (I } \\
\text { would assume } 120 \text { sq. ft.) so the floor area per workstation would be } \\
\text { closer to } 112 \text { sq. ft. This would get you down to } 198 \text { workstations. }\end{array}$ & $\begin{array}{l}\text { Overall plug load of } 0.75 \\
\text { W/sq. ft. is consistent with } \\
\text { PNL studies and other } \\
\text { published value. See also } \\
\text { next comment, even if } \\
\text { number of workstations is } \\
\text { low, other electrical loads } \\
\text { could add to that. Number } \\
\text { of workstations is based on } \\
\text { number of occupants. } \\
\text { Number of workstations is a } \\
\text { reasonable value given the } \\
\text { uncertainties in the } \\
\text { estimates and the fact that } \\
\text { some users now have more } \\
\text { than one computer and/or } \\
\text { display. }\end{array}$ & No action \\
\hline 76 & $\begin{array}{l}\text { Plug } \\
\text { Load }\end{array}$ & $\begin{array}{l}\text { Another general observation that I would pass along is one I heard } \\
\text { from Paul Torcellini related to his work on very low energy buildings. } \\
\text { As the traditional loads shrink, the importance of small peripheral } \\
\text { loads that are generally considered background "noise" in the analysis } \\
\text { (for example, battery chargers for emergency lighting in the building) } \\
\text { grows proportionally. A } 5 \% \text { load becomes } 10 \% \text { when you cut other } \\
\text { loads in half. You may want to explore the extent to which these can }\end{array}$ & See above & No action \\
\hline
\end{tabular}




\begin{tabular}{|c|c|c|c|c|}
\hline No. & Category & Comment & PNNL Response & PNNL Action \\
\hline & & be incorparated into the analysis and treated as variables. & & \\
\hline 77 & SWH & $\begin{array}{l}\text { Feels excessive, you can trade off storage with larger burner input. } \\
\text { What is calculated peak hot water in gpm? An exaggerated example: } \\
\text { assume all hot water ( } 268 \text { gallons) is needed in one hour with a } 70 \mathrm{~F} \\
\text { temperature difference }=156,270 \text { Btuh. I think I could buy one hot } \\
\text { water heater to meet the exaggerated load. Unless you had a shower } \\
\text { room, some would argue design should be representative of a series of } \\
\text { small } 2-3 \text { gallon hot water heaters serving sinks. In theory, aren't sinks } \\
\text { regulated at } 1 / 2 \text { gpm, that is a small load. }\end{array}$ & $\begin{array}{l}\text { The domestic hot water } \\
\text { usage is a reasonable share } \\
\text { of total energy usage and is } \\
\text { a small part of the total. }\end{array}$ & No action \\
\hline 78 & SWH & $\begin{array}{l}\text { For water heating, consideration of a desuperheater for heat recovery } \\
\text { from the air conditioning system would seem worth consideration. } \\
\text { Rather than rushing right to solar thermal systems, you might want to } \\
\text { consider this much less costly approach first. }\end{array}$ & $\begin{array}{l}\text { Tends to be an involved } \\
\text { installation that still needs a } \\
\text { redundant system because } \\
\text { the desuperheater is not } \\
\text { always operating. For the } \\
\text { small loads in the building, } \\
\text { a condensing water heater } \\
\text { or on demand water heater } \\
\text { is a reasonable solution. }\end{array}$ & No action \\
\hline 79 & HVAC & 1. evaporatively cooled condensers & $\begin{array}{l}\text { Specialized to a narrow size } \\
\text { range. Considered high } \\
\text { maintenance. }\end{array}$ & No action \\
\hline 80 & HVAC & $\begin{array}{l}\text { 2. ice storage (Ice Bear- http://www.ice- } \\
\text { energy.com/technology/IceBear/howitworks/tabid/163/Default.aspx) } \\
\text { the ice is made at night when outdoor air temperatures are reduced } \\
\text { and you can get better efficiency out of the refrigeration cycle running } \\
\text { all out building ice instead of trying to modulate in response to load. }\end{array}$ & $\begin{array}{l}\text { Does not reduce energy } \\
\text { usage, but rather peak } \\
\text { demand. }\end{array}$ & No action \\
\hline 81 & HVAC & $\begin{array}{l}\text { 3. Dedicated outdoor air system -- decouple outside air loads and run } \\
\text { them through an independent tempering system (i.e. get OSA to room } \\
\text { temperature and relative humidity separate from coil that mixes the air } \\
\text { and overcools all of it -- saves on reheat and consolidates the major } \\
\text { part of cooling in one coil). Makes doing an ERV a little easier too. } \\
\text { You can still have openings to allow economizer cycles, but they are } \\
\text { independent of the DOAs airstream. }\end{array}$ & $\begin{array}{l}\text { Incorporated in advanced } \\
\text { model with radiant systems. }\end{array}$ & No action \\
\hline 82 & HVAC & $\begin{array}{l}\text { 4. If you look at a DOAS, then consider doing a fan-powered box } \\
\text { system to minimize cooling and reheat. }\end{array}$ & $\begin{array}{l}\text { DOAS provides modest } \\
\text { flow of tempered air with } \\
\text { supply air temperature } \\
\text { reset. Primary comfort is } \\
\text { provided by the radiant } \\
\text { systems. Fan-powered }\end{array}$ & No action \\
\hline
\end{tabular}




\begin{tabular}{|c|c|c|c|c|}
\hline No. & Category & Comment & PNNL Response & PNNL Action \\
\hline & & & $\begin{array}{l}\text { boxes would likely add } \\
\text { expense for modest benefit. }\end{array}$ & \\
\hline 83 & HVAC & $\begin{array}{l}\text { 5. Take a quick look at your placement for the indirect evaporative } \\
\text { coolers -- is seems like you mix return air (RA) \& OSA, then go into } \\
\text { the indirect unit. You should just hit the incoming OSA with indirect } \\
\text { first and then post-mix in order to get the greatest effectiveness in dry } \\
\text { climates. Once you mix, you've already pulled down the temperature } \\
\text { of the OSA and the delta T is not big enough for the wet-bulb } \\
\text { depression to be so effective. }\end{array}$ & $\begin{array}{l}\text { The configuration with } \\
\text { indirect allows greater } \\
\text { energy savings, though the } \\
\text { temperature drop is not as } \\
\text { large since this } \\
\text { configuration also provides } \\
\text { cooling of the portion of the } \\
\text { return air that is not } \\
\text { exhausted. }\end{array}$ & No action \\
\hline 84 & HVAC & $\begin{array}{l}\text { 6. Question your pressure drops for fan energy. What does upsizing } \\
\text { the unit by one size do for your filter and coil pressure drops? What } \\
\text { was the buildup of your assumptions for distribution pressure drop? }\end{array}$ & $\begin{array}{l}\text { Advanced model } \\
\text { incorporates radiant } \\
\text { systems so distribution and } \\
\text { system pressure drops not } \\
\text { applied for final advanced } \\
\text { case, but worth considering } \\
\text { for VAV systems. }\end{array}$ & No action \\
\hline 85 & HVAC & $\begin{array}{l}\text { 7. Consider a lower pressure underfloor air conditioning system that } \\
\text { does not require a } 0.6 \text { in. back pressure on the VAV boxes for } \\
\text { controllability. }\end{array}$ & $\begin{array}{l}\text { Using radiant systems, so } \\
\text { fan powered boxes not part } \\
\text { of advanced model. } \\
\text { Insufficient time to run } \\
\text { underfloor air distribution } \\
\text { model, and not expected } \\
\text { that this would save more } \\
\text { than the radiant/DOAS } \\
\text { alternative. }\end{array}$ & No action \\
\hline 86 & HVAC & 8. consider reducing amount of glass below 33\%. & See response under item 2 & See response under item 2 \\
\hline 87 & HVAC & $\begin{array}{l}\text { 9. Consider providing the air handler serving just the core and a } \\
\text { separate unit for the perimeter with VAV boxes for control -- what is } \\
\text { happening now is that all of the air is pulled down to the worst case } \\
\text { zone required supply temperature (which will be solar driven), } \\
\text { but what you can do instead is to have the core unit do cooling all the } \\
\text { time to pick up local heat loads (which look to be a substantial amount } \\
\text { of area under this criteria), and then a cooling/heating unit for dealing } \\
\text { with the perimeter fluctuations caused by outside air conditions. Your } \\
\text { perimeter unit ends up staying fairly small because it is following the } \\
\text { sun around the perimeter and usually running at 55F regardless during } \\
\text { the cooling season. It helps for comfort in the winter as well and } \\
\text { your reheat can track outside in a compensated loop. Some people }\end{array}$ & $\begin{array}{l}\text { Advance model with } \\
\text { radiant and DOAS. } \\
\text { Otherwise this is a good } \\
\text { strategy, but not sufficient } \\
\text { to get to } 50 \% \text { based on } \\
\text { initial modeling of } \\
\text { improvements to packaged } \\
\text { VAV systems. }\end{array}$ & No action \\
\hline
\end{tabular}




\begin{tabular}{|c|c|c|c|c|}
\hline No. & Category & Comment & PNNL Response & PNNL Action \\
\hline & & also do this with fan coil units. & & \\
\hline 88 & HVAC & $\begin{array}{l}\text { 10. Since you're using electric reheat, you might consider hydronic as } \\
\text { an energy efficiency measure. }\end{array}$ & $\begin{array}{l}\text { Hot water heat would } \\
\text { reduce energy cost, but } \\
\text { increase site energy usage if } \\
\text { from fossil fuel boiler. } \\
\text { Analysis considers site } \\
\text { energy usage. Will discuss } \\
\text { potential to consider source } \\
\text { energy usage in } \\
\text { recommendations for future } \\
\text { work. Electric boiler does } \\
\text { not offer advantages versus } \\
\text { electric reheat. }\end{array}$ & No action \\
\hline
\end{tabular}




\section{Distribution}

No. of

Copies

\# Name

Organization

Address

City, State and ZIP Code

\# Organization

Address

City, State and ZIP Code

Name

Name

Name

Name

Name (\#)

\# Name

Organization

Address

City, State and ZIP Code
No. of

Copies

\section{\# Foreign Distribution}

\# Name

Organization

Address

Address line 2

COUNTRY

\# Local Distribution

Pacific Northwest National Laboratory

Name

Name

Name

Name

Name
Mailstop

Mailstop

Mailstop

Mailstop

(PDF) 



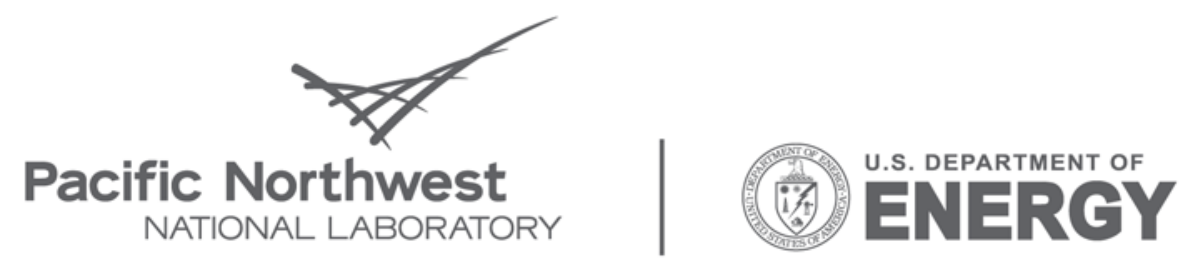

Proudly Operated by Battelle Since 1965

902 Battelle Boulevard

P.O. Box 999

Richland, WA 99352

1-888-375-PNNL (7665)

www.pnl.gov 